
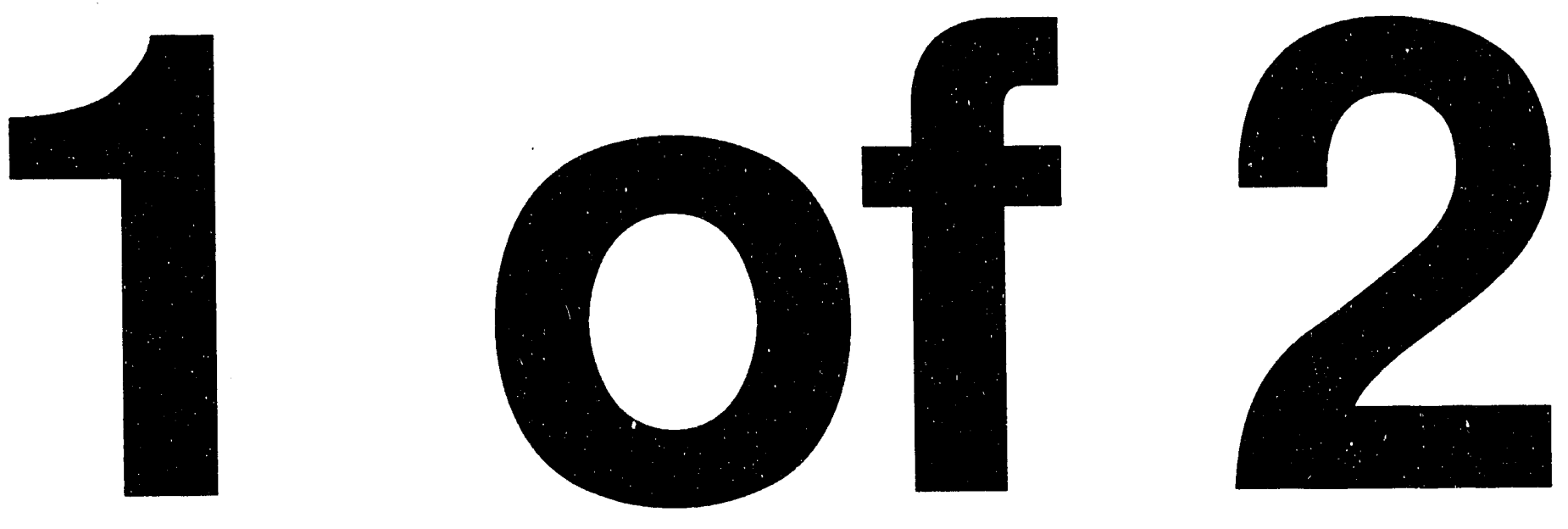


\title{
THE IDAHO NATIONAL ENGINEERING LABORATORY SITE ENVIRONMENTAL REPORT FOR CALENDAR YEAR 1992
}

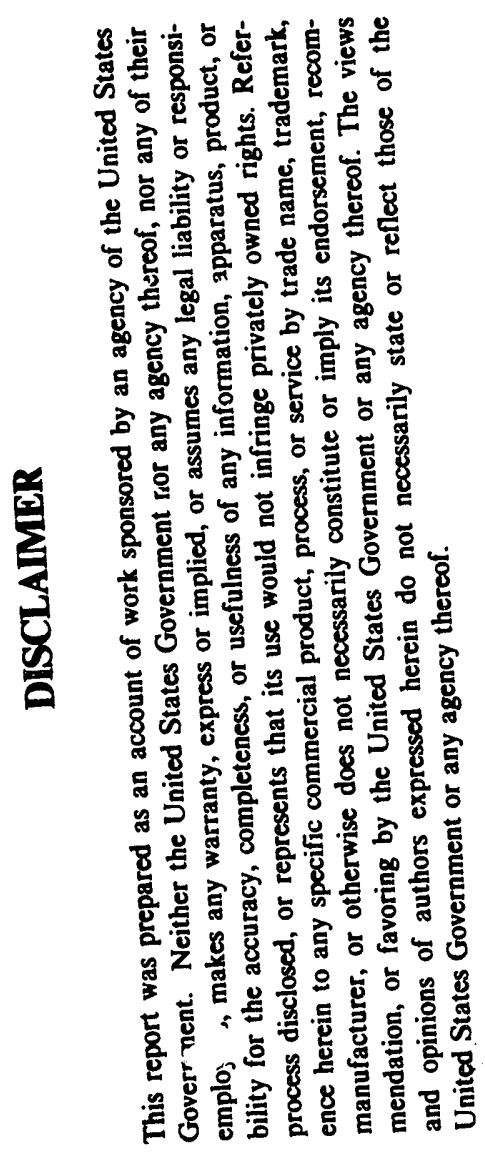

\author{
Diana L. Hoff \\ Russell G. Mitchell \\ Richard Moore \\ Laura Bingham
}

June 1993

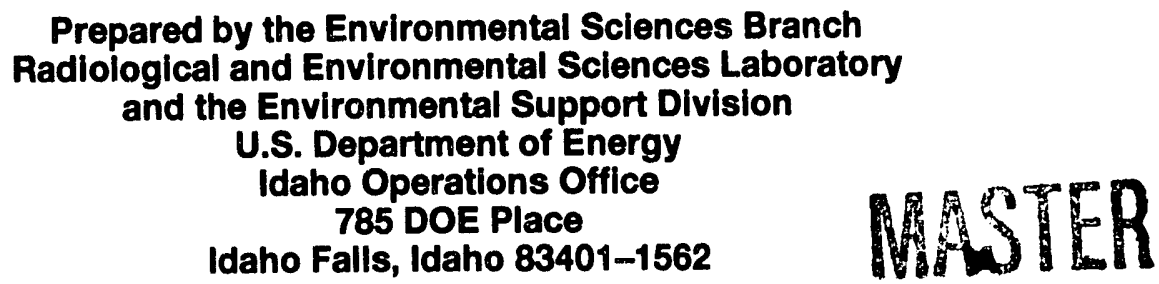




\section{PREFACE}

Every person living in the United States (or the world) is exposed to sources of ionizing radiation-radiant energy that produces ions as it passes through cells. There are three general types of radiation sources: those of natural origin unaffected by human activities, those of natural origin but enhanced by human activities, and those produced by human activities (manmade).

The first group includes terrestrial radiation from natural radiation sources in the ground, cosmic radiation from outer space, and radiation from radionuclides naturally present in the body. Exposures to natural sources may vary depending upon the geographical location and even the altitude at which a person resides. When such exposures are substantially higher than the average, they are considered to be elevated.

The second group includes a variety of natural sources from which the radiation has been increased by human actions. For example, radon exposures in a given home may be elevated because of natural radionuclides in the soil and rock on which the house is built; however, the radon exposures of occupants may be enhanced by characteristics of the home, such as extensive insulation. Another example is the increased exposure to cosmic radiation that airplane passengers receive when traveling at high altitudes.

The third group includes a variety of exposures from manmade materials and devices such as medical X-rays, radiopharmaceuticals used to diagnose and treat disease, and consumer prod-

a. Introductory information is paraphrased from the National Council on Radiation Protection and Measurements (NCRP), lonizing Radiation Exposure of the Population of the United States, NCRP Report No. 93, September 1, 1987, p.1. ucts containing minute quantities of radioactive materials. Exposures may also result from radioactive fallout from nuclear weapons testing, accidents at nuclear power plants, and other such episodic events caused by man's activities in the nuclear industry. Except for major nuclear accidents, such as the one that occurred at Chernobyl, exposures to workers and members of the public from activities at nuclear industries are very small compared to exposures from natural sources.

To verify that exposures resulting from operations at the Department of Energy (DOE) nuclear facilities remain very small, each site at which nuclear activities are underway operates an environmental surveillance program to monitor the air, water, and any other pathway whereby radionuclides from operations might conceivably reach workers or members of the public. Environmental surveillance and monitoring results are reported annually to the DOE-Headquarters (DOE-HQ). This report presents data collected in 1992 for the routine environmental surveillance program conducted by the Radiological and Environmental Sciences Laboratory (RESL) of DOE and the U. S. Geological Survey (USGS) at the Idaho National Engineering Laboratory (INEL) Site, and presents summaries of effluent monitoring data collected by INEL contractors. The report, prepared in accordance with the requirements in DOE Order $5400.1,^{1}$ is not intended to cover the numerous special environmental research programs being conducted at the INEL by RESL, USGS, and others. 


\section{EXECUTIVE SUMMARY OF THE ENVIRONMENTAL SURVEILLANCE PROGRAM}

The results of the various monitoring programs for 1992 indicate that most radioactivity from the INEL operations could not be distinguished from worldwide fallout and natural radioactivity in the region surrounding the INEL Site. Although some radioactive materials were discharged during Site operations, concentrations and doses to the surrounding population were of no health consequence and were far less than State of Idaho and Federal health protection guidelines. The first section of the report summarizes INEL activities related to compliance with environmental regulations and laws for Calendar Year 1992 and January 1 through April 1, 1993. The major portion of the report summarizes results of the RESL environmental surveillance program, which includes the collection of foodstuffs at the INEL boundary and distant offsite locations, and the collection of air and water samples at onsite locations, offsite boundary, and distant locations. The report also compares and evaluates the sample results to appropriate Federal regulations and standards and discusses implications, if any. The USGS ground-water monitoring program is briefly summarized, and data from USGS reports are included in maps showing the spread of contaminants. Effluent monitoring and nonradiological drinking water monitoring performed by INEL contractors are discussed briefly, and data are summarized in tables.

Gross beta measurements, which are used as a screening technique for air sampler filters, were investigated by making statistical comparisons between onsite or boundary location concentrations and the distant community group concentrations. In none of those comparisons in which a statistical difference existed (11\% of the total number of comparisons made) was there any evidence that gross beta concentrations increased due to INEL operations. Gross beta concentrations also show trends for natural and manmade radionuclides.

Air samples were also analyzed for specific radionuclides. Some radionuclides were detected at offsite locations, but their presence was attributable to natural sources, worldwide fallout, or statistical variations in the analyses rather than to Site operations. The annual concentrations of all specific nuclides detected at all locations were well below the derived concentration guides for radiation protection.

Tritium was reported in one winter 1992 onsite air sample but in no offsite samples. Although no clear evidence of INEL operations information could be linked to the presence of tritium in this sample, it was assumed to be due to Site activities since none was detected in offsite samples. The annual mean concentration of tritium at each onsite location was less than $0.0008 \%$ of the DOE annual derived concentration guide for radiation protection of the public.

Approximately $8 \%$ of all drinking water samples collected during 1992 contained detectable concentrations of gross alpha activity, and about $6 \%$ contained detectable gross beta activity. All concentrations of both types of activity were near the minimum detectable concentration and were probably due to natural radioactivity or to statistical variation in the analyses. Annual averages for all onsite and offsite drinking water samples were below the Environmental Protection Agency (EPA) maximum contaminant levels for community drinking water systems. See the section titled "Environmental Standards and Regulations."

No offsite water samples contained detectable tritium concentrations. Five onsite production (drinking water) wells contained measurable concentrations of tritium. An effective dose equivalent of $0.8 \mathrm{~s} . \mathrm{rem} / \mathrm{yr}$ was estimated for INEL workers at the Central Facilities Area (CFA), the location with the highest tritium concentration in drinking water. Concentrations of volatile organic compounds meastired in production wells at Test Area North (TAN) Test Support Facility (TSF) that were slightly above the EPA maximum contaminant levels in 1987, have been in compliance 
through 1992 after appropriate remedial action was taken.

None of the milk samples contained detectable concentrations of I-131 or tritium. Six samples contained concentrations of Sr-90 that were consistent with levels seen in samples nationwide as reported by the EPA. See the section entitled "Foodstuff Sampling" for more details. Some wheat and lettuce samples contained small amounts of $\mathrm{Sr}-90$. The presence of $\mathrm{Sr}-90$ in food samples is probably due to its deposition on soil as a result of worldwide fallout. Low concentrations of Cs-137 were found in muscle and liver tissues of two sheep that had grazed onsite. The levels were consistent with the concentrations from control sheep sampled in earlier years.

Ionizing radiation measured simultaneously at the Site boundary and distant locations showed only natural background levels.

For details on monitoring results, see the appropriate sections that summarize results of radioactive, nonradioactive, and ground water monitoring and surveillance programs.

A measurable amount of radioactivity, primarily in the form of noble gases and tritium, is released into the atmosphere annually from various plant facilities and is subsequently carried offsite. Upon reaching the Site boundary, this radioactivity is in such a low concentration that its effect on direct radiation levels cannot be measured, but its potential contribution to offsite dose equivalents is nevertheless calculated.

The hypothetical maximum individual effective dose equivalent was found to occur near Atomic City and was calculated to be $0.004 \mathrm{mrem}$ $\left(4 \times 10^{-5} \mathrm{mSv}\right)$ using the MESODIF air dispersion model. The calculation considered continuous submersion in and inhalation of radioactivity in air, ingestion of radioactivity in leafy vegetables, and exposure to radioactive particulates deposited on the ground surface at that location. This calculated effective dose equivalent is about $0.0011 \%$ of the natural background radiation effective dose equivalent of approximately
350 mrem per year in this area and is $0.04 \%$ of the EPA radiation protection standard.

The National Emission Standards for Hazardous Air Pollutants (NESHAPs) requires calculation of a potential effective dose equivalent to a maximally exposed individual each year based on INEL emissions and the CAP-88 code. The 1992 NESHAPs dose was $0.0018 \mathrm{mrem}$ which is $0.018 \%$ of the EPA radiation protection standard.

The maximum calculated dose to an individual by either of the methods is clearly in compliance with the applicable radiation protection standards. (See the section entitled "Maximum Individual Dose-Airborne Emissions Pathway Only.")

The maximum potential population dose from submersion, ingestion, inhalation, and deposition to the approximately 121,000 people residing within an $80-\mathrm{km}(50-\mathrm{mi})$ radius from the geographical center between the Test Reactor Area (TRA) and the Idaho Chemical Processing Plant (ICPP) facilities of the INEL Site was estimated to be 0.03 person-rem $\left(3 \times 10^{-4}\right.$ person-Sv) using the MESODIF air dispersion model. This population dose is less than $0.0001 \%$ of the estimated 42,500 person-rem ( 425 person-Sv) population dose from natural background radioactivity. These calculations and their implications are discussed in the section "Assessment of Potential Radiation Dose to the Public."

Calculations indicate that the maximum potential 50-year dose commitment to an individual from ingestion of wild game animals is about $4 \%$ of the DOE radiation protection standard for individuals at points of maximum probable exposure.

The Idaho State University (ISU) Environmental Monitoring Group continued its independent program of collecting and analyzing air, water, and milk samples at selected locations matching some of the RESL environmental surveillance program locations. Comparisons of ISU and RESL data were well within the ranges expected when two different laboratories using different instruments and analytical methods analyze duplicate or simultaneous samples. 


\section{CONTENTS}

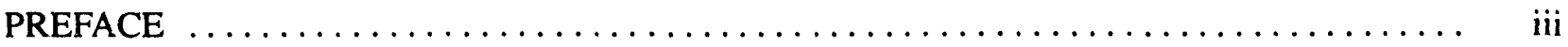

EXECUTIVE SUMMARY OF THE ENVIRONMENTAL SURVEILLANCE PROGRAM $\ldots \ldots$ v

ACRONYMS AND INITIALIZATIONS $\ldots \ldots \ldots \ldots \ldots \ldots \ldots \ldots \ldots \ldots \ldots \ldots \ldots \ldots \ldots \ldots$

INTRODUCTION $\ldots \ldots \ldots \ldots \ldots \ldots \ldots \ldots \ldots \ldots \ldots \ldots \ldots \ldots \ldots \ldots \ldots \ldots$

ENVIRONMENTAL COMPLIANCE INFORMATION SUMMARY $\ldots \ldots \ldots \ldots \ldots \ldots \ldots$

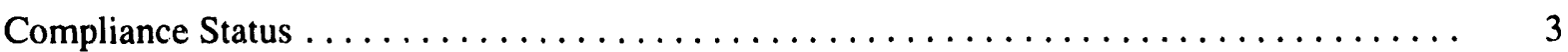

Comprehensive Environmental Response, Compensation, and Liability Act (CERCLA) 3

Natural Resource Trusteeship \& Natural Resources Damage Assessment ......... 3

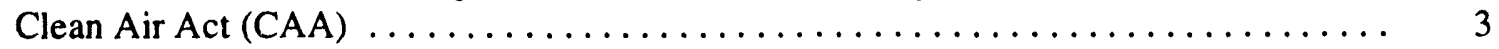

National Emission Standards for Hazardous Air Pollutants (NESHAPs) $\ldots \ldots \ldots \ldots \ldots$

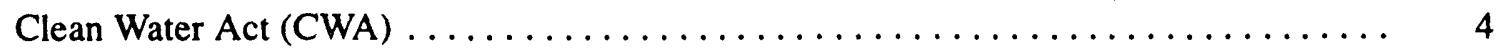

Resource Conservation and Recovery Act (RCRA) $\ldots \ldots \ldots \ldots \ldots \ldots \ldots \ldots \ldots$

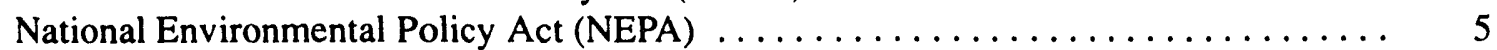

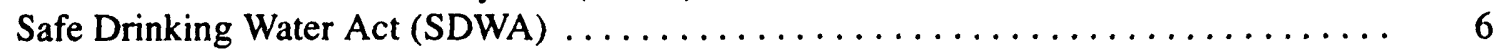

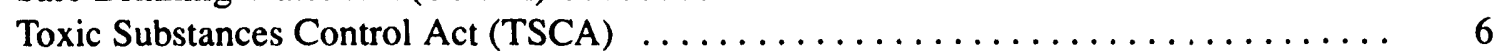

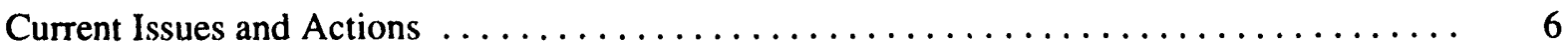

Environmental Oversight and Monitoring Agreement $\ldots \ldots \ldots \ldots \ldots \ldots \ldots \ldots$

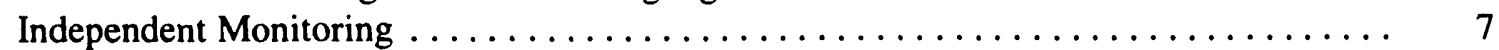

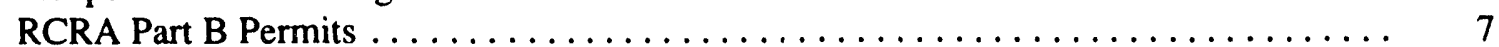

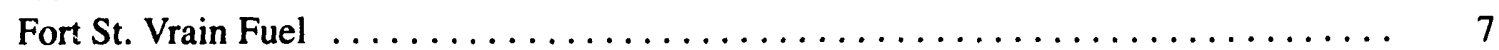

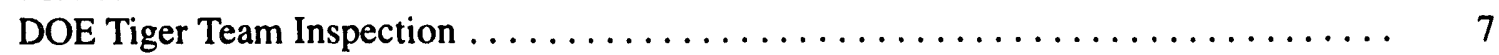

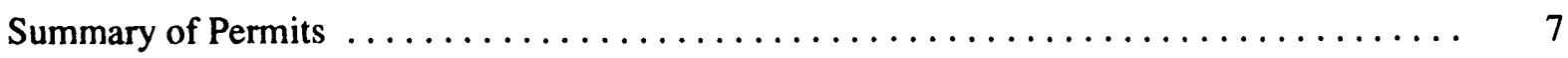

ENVIRONMENTAL PROGRAM INFORMATION $\ldots \ldots \ldots \ldots \ldots \ldots \ldots \ldots \ldots \ldots \ldots$

Summary of Environmental Compliance Activities $\ldots \ldots \ldots \ldots \ldots \ldots \ldots \ldots$

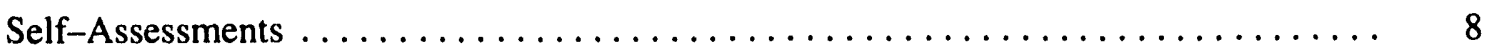

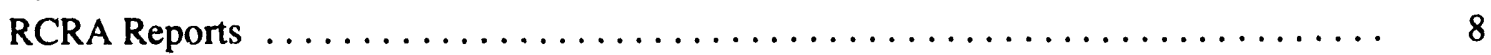

Waste Minimization and Pollution Prevention Awareness Program ........... 8

Environmental Training Conducted Onsite $\ldots \ldots \ldots \ldots \ldots \ldots \ldots \ldots \ldots \ldots$

Summary of RESL Environmental Surveillance Activities $\ldots \ldots \ldots \ldots \ldots \ldots \ldots \ldots$

ENVIRONMENTAL RADIOLOGICAL PROGRAM INFORMATION $\ldots \ldots \ldots \ldots \ldots \ldots \ldots$

General Compliance Information $\ldots \ldots \ldots \ldots \ldots \ldots \ldots \ldots \ldots \ldots \ldots \ldots \ldots \ldots \ldots \ldots \ldots \ldots \ldots$

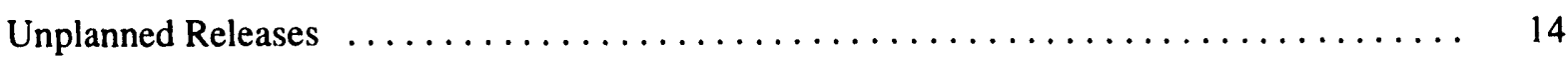


Summary of RESL Environmental Surveillance Program Results $\ldots \ldots \ldots \ldots \ldots \ldots \ldots \ldots$

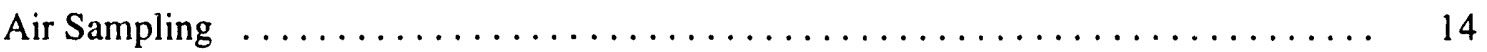

Radiological and Environmental Sciences Laboratory (RESL) Water Sampling ..... 21

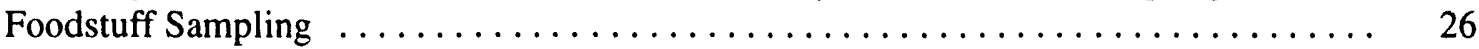

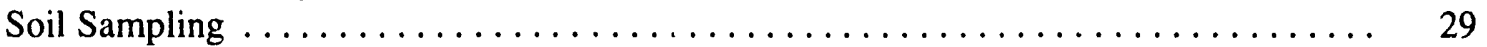

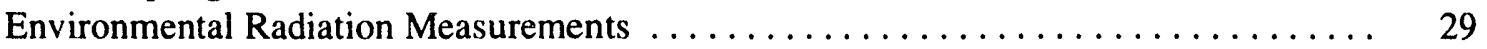

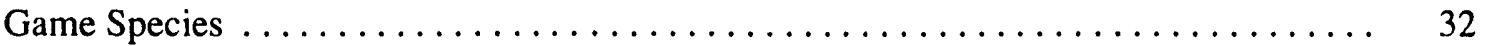

Summary of Radioactive Effluent Monitoring $\ldots \ldots \ldots \ldots \ldots \ldots \ldots \ldots \ldots \ldots \ldots$

Assessment of Potential Radiation Dose to the Public $\ldots \ldots \ldots \ldots \ldots \ldots \ldots \ldots$

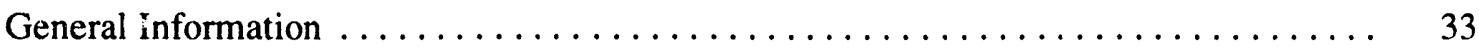

Maximum Individual Dose-Airborne Emissions Pathway Only ............ 36

Maximum Individual Dose-Game Ingestion Pathway $\ldots \ldots \ldots \ldots \ldots \ldots \ldots \ldots . \ldots \ldots$

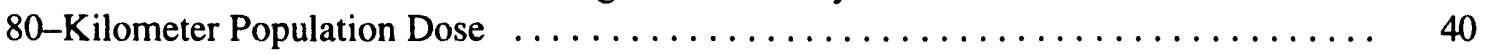

GROUND WATER SURVEILLANCE PROGRAM INFORMATION $\ldots \ldots \ldots \ldots \ldots \ldots \ldots \ldots \quad 43$

General USGS Program Information $\ldots \ldots \ldots \ldots \ldots \ldots \ldots \ldots \ldots \ldots \ldots \ldots \ldots \ldots \ldots$

Summary of Radiological Surveillance Results $\ldots \ldots \ldots \ldots \ldots \ldots \ldots \ldots \ldots \ldots \ldots$

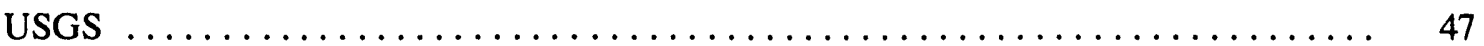

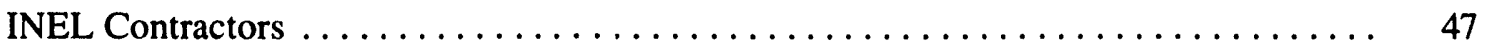

Summary of Nonradiological Surveillance Results $\ldots \ldots \ldots \ldots \ldots \ldots \ldots \ldots \ldots \ldots$

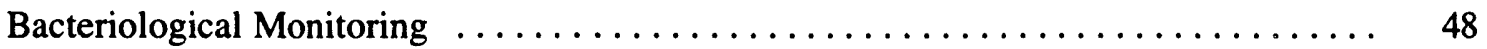

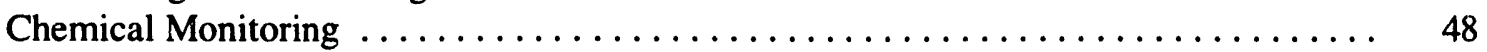

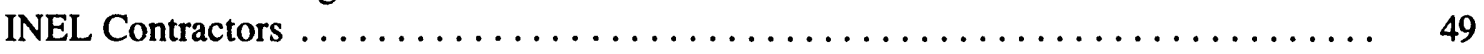

ENVIRONMENTAL NONRADIOLOGICAL PROGRAM INFORMATION $\ldots \ldots \ldots \ldots \ldots .53$

Continuous Release Reporting $\ldots \ldots \ldots \ldots \ldots \ldots \ldots \ldots \ldots \ldots \ldots \ldots \ldots \ldots \ldots \ldots \ldots \ldots \ldots \ldots$

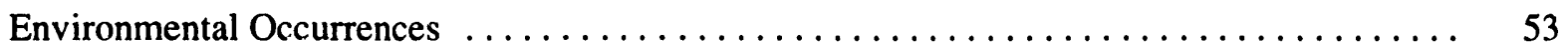

SARA Title III Reporting Requirements $\ldots \ldots \ldots \ldots \ldots \ldots \ldots \ldots \ldots \ldots \ldots \ldots \ldots \ldots \ldots \ldots \ldots \ldots$

Summary of RESL Air Sampling Results $\ldots \ldots \ldots \ldots \ldots \ldots \ldots \ldots \ldots \ldots \ldots$

Summary of Contractor Nonradioactive Effluent Monitoring $\ldots \ldots \ldots \ldots \ldots \ldots$

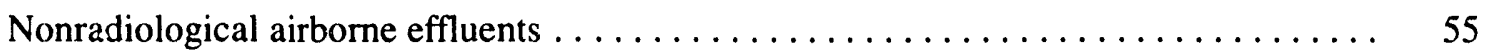

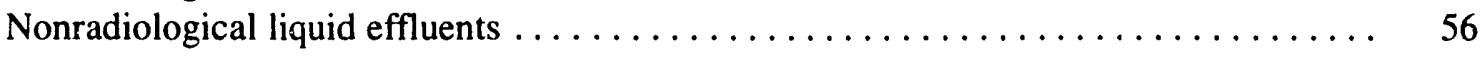

QUALITY ASSURANCE $\ldots \ldots \ldots \ldots \ldots \ldots \ldots \ldots \ldots \ldots \ldots \ldots \ldots \ldots \ldots \ldots \ldots \ldots \ldots \ldots \ldots$

ENVIRONMENTAL STANDARDS AND REGULATIONS $\ldots \ldots \ldots \ldots \ldots \ldots \ldots \ldots \ldots \ldots$ 
APPENDIX A-MAJOR PROGRAMS, LOCATION, GEOLOGY, AND CLIMATOLOGY $\ldots . . \quad$ A-1

APPENDIX B-SUMMARY TABLES FROM THE INEL ENVIRONMENTAL SURVEILLANCE AND CONTRACTOR EFFLUENT MONITORING PROGRAMS $\ldots \ldots \ldots \ldots \ldots \ldots \ldots \ldots \ldots$ B-1

APPENDIX C-STATISTICAL METHODS $\ldots \ldots \ldots \ldots \ldots \ldots \ldots \ldots \ldots \ldots \ldots \ldots \ldots$

\section{FIGURES}

1. Typical vegetation on the INEL Site $\ldots \ldots \ldots \ldots \ldots \ldots \ldots \ldots \ldots \ldots \ldots \ldots \ldots \ldots \ldots$

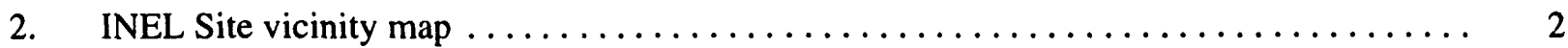

3. Potential pathways from the INEL to $\operatorname{man} \ldots \ldots \ldots \ldots \ldots \ldots \ldots \ldots \ldots \ldots \ldots \ldots \ldots$

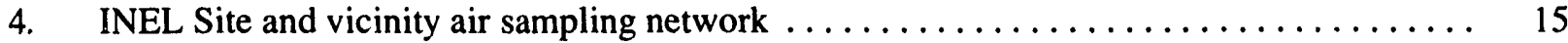

5. Site and distant gross beta concentrations in air $\ldots \ldots \ldots \ldots \ldots \ldots \ldots \ldots \ldots \ldots \ldots \ldots \ldots$

6. Boundary and distant gross beta concentraitions in air $\ldots \ldots \ldots \ldots \ldots \ldots \ldots \ldots \ldots$

7. Boundary and distant water, milk, and wheat sampling locations and environmental

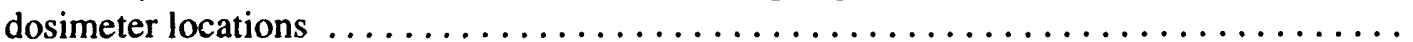

8. Distribution of tritium in the Snake River Plain aquifer in the southcentral part

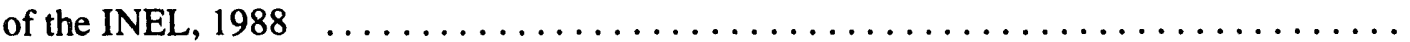

9. Distribution of Sr-90 in the Snake River Plain aquifer in the southcentral

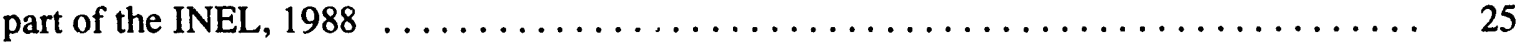

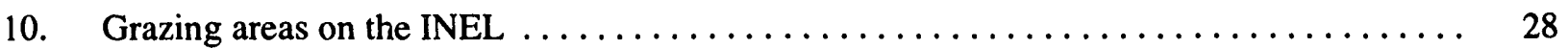

11. Offsite soil sampling locations in the INEL vicinity $\ldots \ldots \ldots \ldots \ldots \ldots \ldots \ldots \ldots$

12. Detailed diagram of possible exposure pathways of INEL radioactive materials to

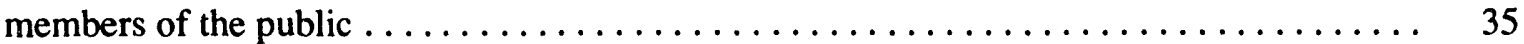

13. 1992 average of mesoscale dispersion isopleths of air concentrations at ground level,

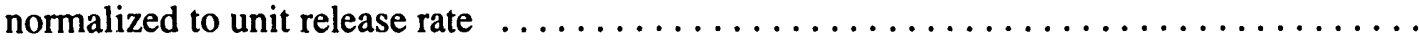

14. Nuclides contributing to maximum individual dose in $1992 \ldots \ldots \ldots \ldots \ldots \ldots \ldots$

15. USGS sample location map for the INEL Site and vicinity $\ldots \ldots \ldots \ldots \ldots \ldots \ldots \ldots$

16. USGS detailed sample location map for ICPP, TRA, RWMC $\ldots \ldots \ldots \ldots \ldots \ldots \ldots \ldots$

17. Distribution of nitrate concentrations in the Snake River Plain aquifer in the

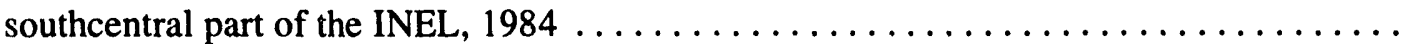

18. Distribution of nitrate concentrations in the Snake River Plain aquifer in the southcentral part of the INEL, 1988 


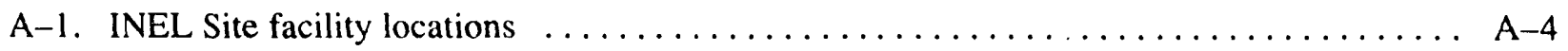

B-1. Tritium concentrations in onsite drinking water wells, $1988-1992 \ldots \ldots \ldots \ldots \ldots \ldots$ B-3

B-2. Nuclides contributing to maximum individual doses, $1988-1991 \ldots \ldots \ldots \ldots \ldots \ldots$ B-4

\section{TABLES}

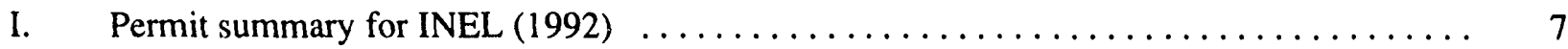

II. RESL environmental surveillance program summary $\ldots \ldots \ldots \ldots \ldots \ldots \ldots \ldots \ldots \ldots$

III. USGS ground water monitoring program summary $\ldots \ldots \ldots \ldots \ldots \ldots \ldots \ldots \ldots \ldots$

IV. Estimated natural background effective dose equivalent (1992) $\ldots \ldots \ldots \ldots \ldots \ldots \ldots$

V. Maximum individual effective dose equivalent $(1992) \ldots \ldots \ldots \ldots \ldots \ldots \ldots \ldots$

VI. $\quad 80-$ kilometer population dose $(1992) \ldots \ldots \ldots \ldots \ldots \ldots \ldots \ldots \ldots \ldots \ldots \ldots \ldots \ldots \ldots$

VII. Summary of annual effective dose equivalents due to 1992 INEL operations . . . . . . 42

VIII. NIST quality assurance comparison test results $\ldots \ldots \ldots \ldots \ldots \ldots \ldots \ldots \ldots \ldots$

IX. DOE Environmental Measurements Laboratory Quality Assurance Program results

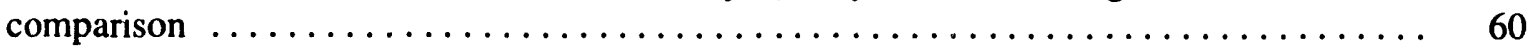

X. Comparison of ISU and RESL air monitoring resulis (1992) $\ldots \ldots \ldots \ldots \ldots \ldots$

XI. Comparison of ISU and RESL water monitoring resulıs (1992) $\ldots \ldots \ldots \ldots \ldots$

XII. Radiation standards for protection of the public in the vicinity of DOE facilities $\ldots \ldots \ldots 66$

XIII. Derived concentration guides for radiation protection $\ldots \ldots \ldots \ldots \ldots \ldots \ldots \ldots \ldots$

XIV. Ambient air quality standards $\ldots \ldots \ldots \ldots \ldots \ldots \ldots \ldots \ldots \ldots \ldots \ldots \ldots \ldots$

XV. Maximum contaminant levels for nontransient noncommunity drinking water systems $\ldots .68$

A-1. Tabulation of facilities at the Idaho National Engineering Laboratory (1992) . . . . . A A-5

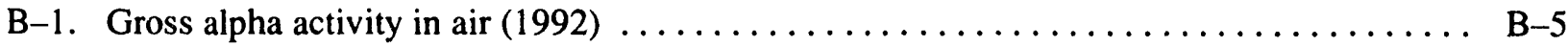

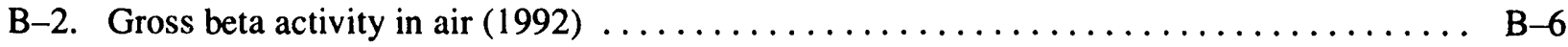

B-3. Gross beta statistical comparisons by location $(1992) \ldots \ldots \ldots \ldots \ldots \ldots \ldots \ldots \ldots$

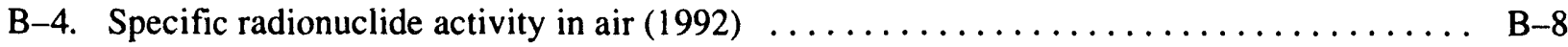

B-5. Radionuclide concentrations in site drinking water (1992) $\ldots \ldots \ldots \ldots \ldots \ldots \ldots \ldots$ B-9

B-6. Strontium-90 concentrations in garden lettuce $(1988-1992) \ldots \ldots \ldots \ldots \ldots \ldots \ldots \ldots$ B-10 
B-7. Strontium-90 concentrations in wheat $(1988-1992) \ldots \ldots \ldots \ldots \ldots \ldots \ldots \ldots \ldots$

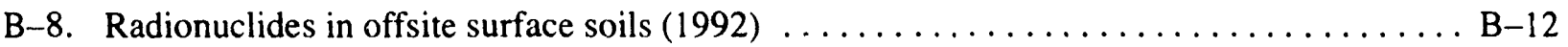

B-9. Environmental radiation exposures $(1988-1992) \ldots \ldots \ldots \ldots \ldots \ldots \ldots \ldots \ldots \ldots \ldots \ldots$

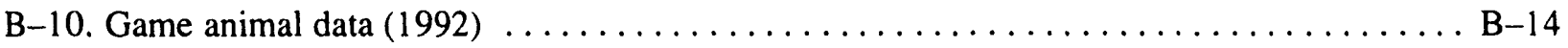

B-11. Radionuclide composition of airborne effluents $(1992) \ldots \ldots \ldots \ldots \ldots \ldots \ldots \ldots$ B-15

B-12. Radionuclide composition of liquid effluents released onsite (1992) $\ldots \ldots \ldots \ldots \ldots$. B-16

B-13. EG\&G Idaho radiological drinking water data (1992) (analyses by Accu-Labs) ...... B-17

B-14. Purgeable organic compound concentrations in ground water (1992)

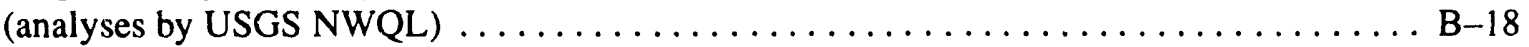

B-15. EG\&G Idaho data for volatile organic compounds in drinking water (1992) $\ldots \ldots \ldots \ldots$ B-19

B-16. WINCO inorganic data from production and potable wells (1992) (analyses by ICPP) ... B-21

B-17. Total suspended particulate matter concentrations in $\operatorname{air}(1992) \ldots \ldots \ldots \ldots \ldots \ldots . .6 \ldots$

B-18. Nine-year summary of particulate matter concentrations $(1983-1992) \ldots \ldots \ldots \ldots$ B-23

B-19. Summary of $\mathrm{NO}_{2}$ and $\mathrm{SO}_{2}$ emissions and ambient monitoring results (1988-1992) $\ldots .$. B-24

B-20. ANL-W Seepage Pond monitoring data $(1992) \ldots \ldots \ldots \ldots \ldots \ldots \ldots \ldots \ldots \ldots \ldots$

B-21. B\&W Idaho, Inc., Boiler Effluent/Sanitary Waste data (First Quarter 1992)

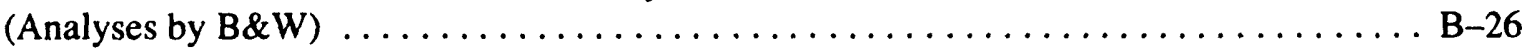

B-22. TRA liquid effluent to cold waste pond inorganic monitoring data (1992) $\ldots \ldots \ldots \ldots$ B-27

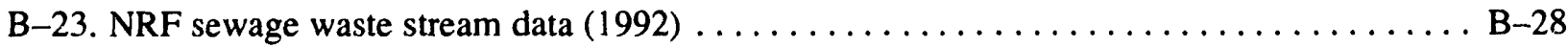

B-24. WINCO service waste inorganic monitoring data (1992) (analyses by WINCO) ....... B-29 


\section{ACRONYMS AND INITIALIZATIONS}

ACB Analytical Chemistry Branch of RESL

ANL-W Argonne National Laboratory-West

ARA Auxiliary Reactor Area

ARVFS Army Reentry Vehicle Facility Site

B\&W Babcock \& Wilcox Idaho, Inc.

CAA Clean Air Act

CERCLA Comprehensive Environmental

Response, Compensation, \&

Liability Act

CFA Central Facilities Area

CFR Code of Federal Regulations

CFSGF Coal-Fired Steam Generating Facility

COCA Consent Order and Compliance Agreement

CTF Containment Test Facility

CWA Clean Water Act

DCG Derived concentration guide

DEQ Idaho Division of Environmental Quality

dl detection limit

DOC Dissolved organic carbon

DOE U.S. Department of Energy.

DOE-HQ Department of Energy, Headquarters in Washington, D.C.

DOE-ID Department of Energy, Idaho Operations Office

DWR Idaho Department of Water Resources

EA Environmental Assessment

EBR-I Experimental Breeder Reactor-I
EBR-II Experimental Breeder Reactor-II

EFS Experimental Field Station

EIS Environmental Impact Statement

EML Environmental Measurements Laboratory (New York)

EMSL-LV Environmental Monitoring Systems Laboratory in Las Vegas

EMU Environmental Monitoring Unit (EG\&G Idaho)

EPA U. S. Environmental Protection Agency

EPA-10 EPA Region 10

EPCRA Emergency Planning and Community Right-To-Know Act

ER\&WM Environmental Restoration \& Waste Management

FFA/CO Federal Facility Agreement and Consent Order

FFCA Federal Facility Compliance Act

FONSI Finding of No Significant Impact

GW ground water

HCWHF Hazardous Chemical Waste Handling Facility

IAEA International Atomic Energy Agency

ICPP Idaho Chemical Processing Plant

INEL Idaho National Engineering Laboratory

INWMIS INEL Nonradiological Waste Management Information System

ISU Idaho State University

LDR Land Disposal Restrictions

LEPC Local Emergency Planning Committee 


\begin{tabular}{|c|c|c|c|}
\hline LQB & Laboratory Quality Branch of RESL & RESL & $\begin{array}{l}\text { Radiological and Environmental } \\
\text { Sciences Laboratory }\end{array}$ \\
\hline $\begin{array}{l}\text { MCL } \\
\text { MDC }\end{array}$ & $\begin{array}{l}\text { Maximum Contaminant Level } \\
\text { minimum detectable concentration }\end{array}$ & RSB & Radiological Sciences Branch \\
\hline NCP & National Compliance Plan & RWMC & $\begin{array}{l}\text { Radioactive Waste Management } \\
\text { Complex }\end{array}$ \\
\hline NCRP & $\begin{array}{l}\text { National Council on Radiation } \\
\text { Protection and Measurements }\end{array}$ & RWMIS & $\begin{array}{l}\text { Radioactive Waste Management } \\
\text { Information System }\end{array}$ \\
\hline NEPA & National Environmental Policy Act & SAA & Satellite Accumulation Area \\
\hline NESHAPs & $\begin{array}{l}\text { National Emission Standards for } \\
\text { Hazardous Air Pollutants }\end{array}$ & SDWA & Safe Drinking Water Act \\
\hline NIST & $\begin{array}{l}\text { National Institute of Standards and } \\
\text { Technology }\end{array}$ & SERC & $\begin{array}{l}\text { State Emergency Response } \\
\text { Commission }\end{array}$ \\
\hline NON & Notice of Noncompliance & SMC & $\begin{array}{l}\text { Specific Manufacturing Capability } \\
\text { Program or Facility }\end{array}$ \\
\hline NOV & Notice of Violation & SW & surface water \\
\hline NPDES & $\begin{array}{l}\text { National Pollutant Discharge } \\
\text { Elimination System }\end{array}$ & $\begin{array}{l}\text { TAN } \\
\text { TCE }\end{array}$ & $\begin{array}{l}\text { Test Area North } \\
\text { trichloroethylene }\end{array}$ \\
\hline NPL & $\begin{array}{l}\text { National Priorities List } \\
\text { National Response Center }\end{array}$ & TRA & Test Reactor Area \\
\hline NRF & Naval Reactors Facility & TSCA & Toxic Substances Control Act \\
\hline NWCF & New Waste Calcining Facility & $\begin{array}{l}\text { TSF } \\
\text { USGS }\end{array}$ & $\begin{array}{l}\text { Technical Services Facility } \\
\text { U. S. Geological Survey }\end{array}$ \\
\hline NWQL & $\begin{array}{l}\text { National Water Quality Laboratory } \\
\text { (USGS) }\end{array}$ & UST & Underground Storage Tank \\
\hline OU & Operable Unit & VANB & $\begin{array}{l}\text { Van Buren Boulevard-RESI. } \\
\text { sampling location }\end{array}$ \\
\hline OPB & $\begin{array}{l}\text { State of Idaho Operating Permits } \\
\text { Bureau }\end{array}$ & VOC & volatile organic compound \\
\hline PBF & Power Burst Facility & WAG & Waste Area Group \\
\hline PCB & polychlorinated biphenyl & WEC & Westinghouse Electric Corporation \\
\hline ppm & parts per million & WERF & $\begin{array}{l}\text { Waste Experimental Reduction } \\
\text { Facility }\end{array}$ \\
\hline $\begin{array}{l}\text { PTC } \\
\text { PWS }\end{array}$ & $\begin{array}{l}\text { Permit to Construct } \\
\text { Public Water System }\end{array}$ & WINCO & $\begin{array}{l}\text { Westinghouse Idaho Nuclear } \\
\text { Company }\end{array}$ \\
\hline QAP & $\begin{array}{l}\text { Quality Assessment Program (DOE } \\
\text { EML) }\end{array}$ & WRC & $\begin{array}{l}\text { Weapons Range Complex (also } \\
\text { RIFR) }\end{array}$ \\
\hline RCRA & $\begin{array}{l}\text { Resource Conservation and } \\
\text { Recovery Act }\end{array}$ & WRRTF & $\begin{array}{l}\text { Water Reactor Research Test } \\
\text { Facility }\end{array}$ \\
\hline
\end{tabular}




\section{THE IDAHO NATIONAL ENGINEERING LABORATORY SITE ENVIRONMENTAL REPORT FOR CALENDAR YEAR 1992 INTRODUCTION}

The Idaho National Engineering Laboratory (INEL) of the U. S. Department of Energy (DOE) was established by the Federal Government in 1949 to conduct research and further the development of nuclear reactors and related equipment. Major DOE programs at the Site include test irradiation services, uranium recovery from highly enriched spent fuels, calcination of liquid radioactive waste solutions, light-water-cooled reactor safety testing and research, operation of research reactors, environmental restoration at the Site, and storage and surveillance of solid transuranic wastes. Major facilities at the INEL are operated by Argonne National LaboratoryWesi (ANL-W), EG\&G Idaho, Inc. (EG\&G Idaho), Babcock and Wilcox Idaho, Inc. (B\&W Idaho), Westinghouse Electric Corporation (WEC), and Westinghouse Idaho Nuclear Company (WINCO).

The INEL Site is located on the upper Snake River Plain in southeastern Idaho. Vegetation and wildlife on the Site are typical of those found in a cool, desert-shrub biome. Figure 1 shows a part of the Site and its vegetation. In 1975, the INEL became the second of the nation's seven National Environmental Research Parks, where scientists from universities, government, and private agencies study environmental changes caused by

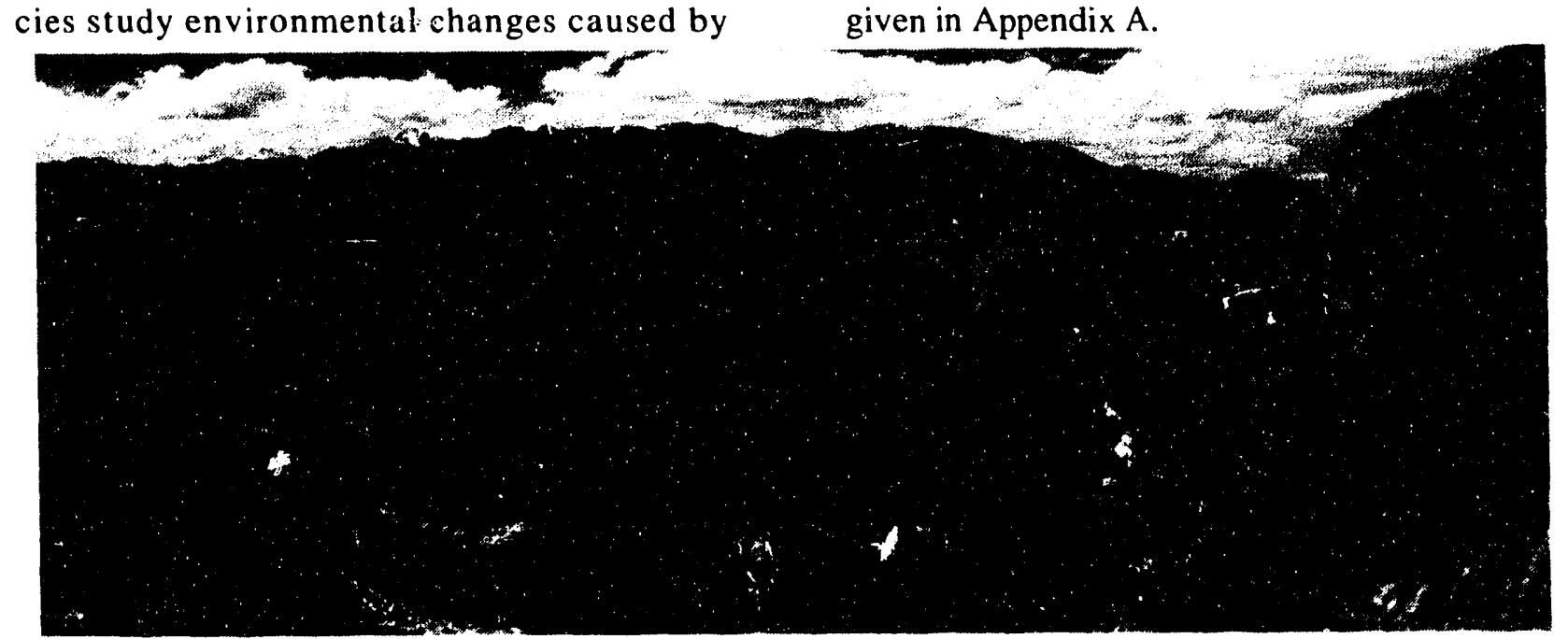

Figure 1. Typical vegetation on the INEL Site.

man's activities and obtain data subsequently applied to making land-use decisions.

The surface of the plain is a combination of basalt (lava) outcrops and alluvial sedimentary deposits. There are no surface streams or rivers flowing from onsite to offsite locations, but the Snake River Plain aquifer lies beneath the INEL Site. The Big and Little Lost Rivers and Birch Creek, which originate in mountains to the northwest, flow onto the Site and sink into its porous soils. Water from the aquifer and from surface streams and rivers of the Sriake River Plain is used for drinking water and crop irrigation.

The INEL Site has an area of $2300-\mathrm{km}^{2}$ $\left(890-\mathrm{mi}^{2}\right)$. The nearest Site boundaries are $35 \mathrm{~km}$ (22 mi) west of Idaho Falls, $37 \mathrm{~km}(23 \mathrm{mi})$ northwest of Blackfoot, $71 \mathrm{~km}(44 \mathrm{mi})$ northwest of Pocatello, and $11 \mathrm{~km}(7 \mathrm{mi})$ east of Arco, Idaho (see Figure 2). With a population of about 1100, Arco is the largest boundary community in the area surrounding the Site. Approximately 121,000 people reside within a radius of $80 \mathrm{~km}$ $(50 \mathrm{mi})$ of the Site's operational center, but there are no residents within $16 \mathrm{~km}(10 \mathrm{mi})$ of that center.

A more detailed description of the Site location, environment, and current major activities is given in Appendix A. 


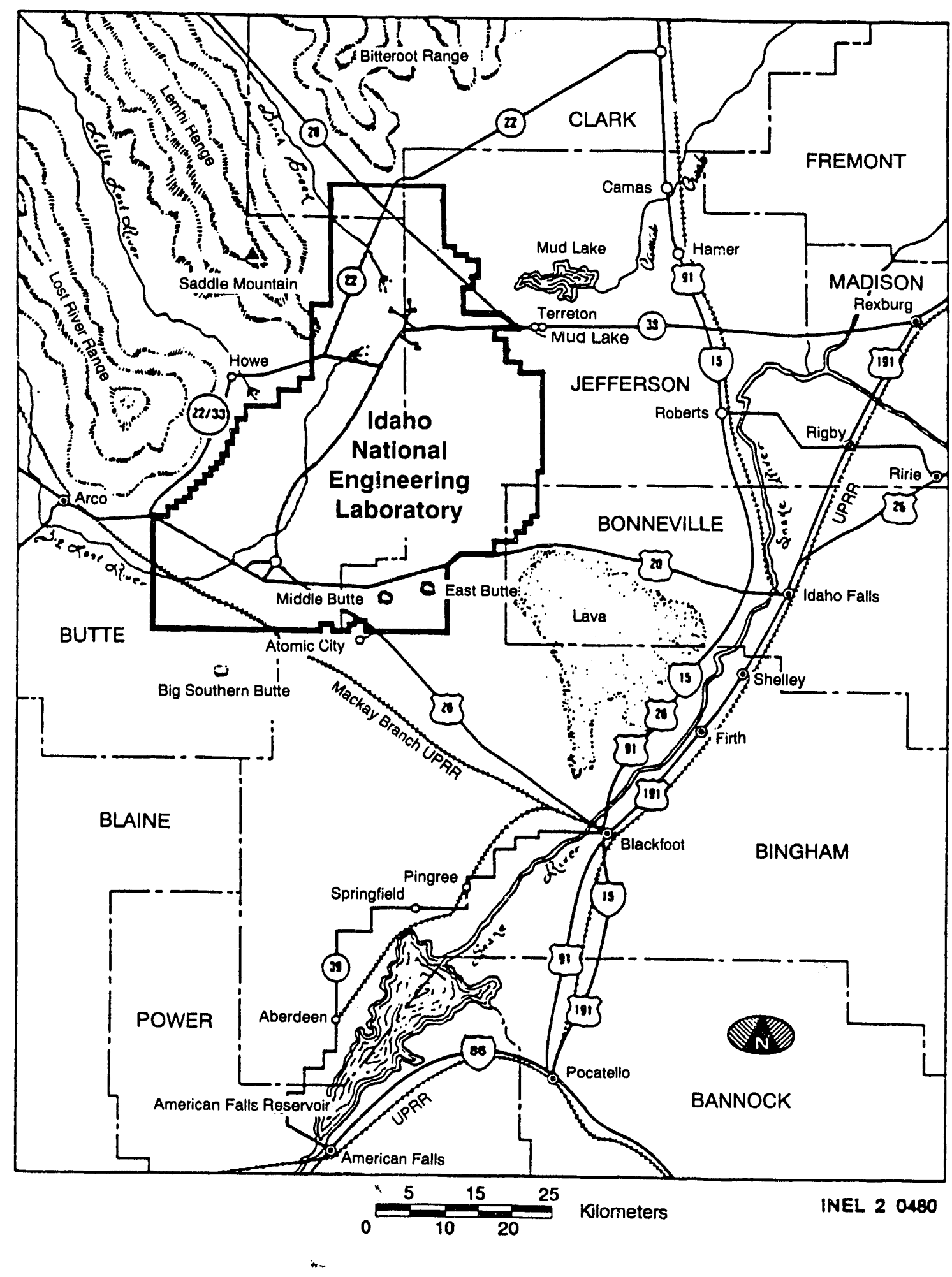

Figure 2. INEL Site vicinity map. 


\section{ENVIRONMENTAL COMPLIANCE INFORMATION SUMMARY}

\section{Compliance Status}

The INEL is committed to operating in compliance with all environmental laws, regulations, Executive Orders, DOE Orders, and compliance agreements with the EPA and State agencies. The following is a summary of the INEL's current compliance status with major environmental statutes for the period January 1992 through April 1993.

Comprehensive Environmental Response, Compensation, and Liability Act (CERCLA). Department of Energy, Idaho Operations Office (DOE-ID) is responsible for environmental restoration efforts at the INEL. The INEL was placed on the National Priorities List (NPL) on November 29, 1989, and environmental restoration activities are being conducted in accordance with the Federal Facilities Agreement and Consent Order (FFA/CO) which was signed on December 9, 1991, and in consultation with the State of Idaho and EPA Region 10 (EPA-10).

The FFA/CO is implemented by an Action Plan which supersedes the RCRA 3008(h) Consent Order and Compliance Agreement (COCA) executed on July 10,1987 . The INEL has been divided into ten Waste Area Groups (WAGs) to facilitate environmental remediation efforts. WAGs 1 through 9 generally correspond to surface and subsurface concerns associated with the Snake River Plain Aquifer, and those areas outside the bounds of facility-specific WAGs are designated as WAG 10. The WAGs are further divided into 96 Operable Units (OUs).

\footnotetext{
Natural Resource Trusteeship \& Natural Resource Damage Assessment. Executive Order 12580, Section 2(d), appoints the Secretary of Energy as the primary Federal Natural Resource Trustee for natural resources located on, over, or under land administered by DOE. Natural resource trustees act on behalf of the public when natural resources may be injured, destroyed, lost, or threatened as a result of a
}

release of a hazardous substance. Federal agencies, states, and Indian tribes are designated as natural resource trustees at National Compliance Plan (NCP) Sections 300.600(b), 300.605, and 300.610 , respectively. In the case of INEL, other potential natural resource trustees with possible jurisdiction over trust resources are the State of Idaho, Department of Interior, and ShoshoneBannock Tribes.

Past releases of hazardous substances resulted in INELs placement on the National Priorities List (Listing). These same releases create the potential for injury to natural resources. Therefore, in accordance with CERCLA, Section 104(b)(2) and NCP 300.15(j), DOE-ID formally notified the other natural resource trustees of potential injury to natural resources in a letter dated July 7, 1992. A meeting to discuss coordination between trustees was held March 17, 1993, and a proposal for formalizing a protocol addressing natural resource injury was mailed by DOE-ID to the other trustees on April 2, 1993.

Clean Air Act (CAA). The INEL has applied for and received several air quality permits, permit exemptions, below regulatory concerns, and permit applicability determinations from the Idaho Division of Environmental Quality (DEQ). In June 1992, after several years of effort, the INEL obtained a permit for the Specific Manufacturing Capability (SMC) Project.

The Pilot Plants at the ICPP were issued a permit to construct (PTC) in February 1992. The permit was contested by a member of the public. The motions for summary judgment were filed in August 1992. On October 15, 1992, a hearing was begun on the motions for summary judgment. In the proposed Decision and Order, dated December 18,1992 , the hearing officer granted the motions for summary judgment. The proposed decision is now pending before the State Board of Health and Welfare with resolution anticipated at the Board's June meeting.

The air Notice of Violation (NOV) issued in June 1991, for the construction/operation of an air 
pollution source without a permit (the hazardous waste facility at ICPP), will soon be resolved. The DEQ has issued a proposed permit and solicited public comment. The permit is anticipated to be issued by summer of 1993 .

The first annual update of the INEL Air Emission Inventory was completed and submitted to the State of Idaho in June 1992. This inventory currently catalogs all vents and stacks at the INEL, and indicates the actual and maximum potential emissions of criteria pollutants and gross radionuclides from all sources and potential sources of air pollution. The information is stored on a database where it can be easily updated and accessed for reporting purposes.

The INEL, in cooperation with the State of Idaho, is conducting an Air Toxics Inventory and has submitted draft inventory data for all areas of the INEL except the ICPP to the State for review. The ICPP inventory is still in progress. The INEL and the State are preparing Technical Memorandums, based on the inventories and facility inspections, that are intended to serve as the basis for the operating permits required under Title $\mathrm{V}$ of the 1990 Clean Air Act Amendments.

\section{National Emission Standards for Hazard- ous Air Pollutants (NESHAPs). In} June 1992, DOE-ID submitted the NESHAPs Annual Report. The resulting effective dose equivalent to the public resulting from monitored air emission pathways at the INEL was $4.1 \times 10^{-3} \mathrm{mrem} / \mathrm{yr}\left(4.1 \times 10^{-5} \mathrm{mSv} / \mathrm{yr}\right)$. In August 1992, DOE-ID submitted the 1990/1991 Supplement to the NESHAPs Annual Report submitted in June. The supplement addressed the air emissions for the unmonitored release pathways and fugitive emissions sources which were included by EPA request in the NESHAPs Annual Report. The additional effective dose equivalent resulting from the unmonitored and diffuse airborne radiological emissions was $1.7 \times 10^{-5} \mathrm{mrem}$. When this amount was added to the monitored pathways previously reported the resulting total 1991 effective dose equivalent was $4.3 \times 10^{-3}$ mrem.
The INEL has developed a Periodic Confirmatory Measurements program as required by NESHAPs. This measurements program applies to all air emission pathways that do not require continuous monitoring. This program has been implemented for the calendar year 1993, and the results will be included in the 1993 NESHAP's Annual Report to be published in 1994.

Clean Water Act (CWA). On February 8, 1993, the EPA issued a Storm Water General Permit (number IDROOA 194) to DOE-ID authorizing coverage under the National Pollutant Discharge Elimination System (NPDES) Storm Water General Permit for Industrial Activities at the INEL. The area of coverage includes industrial activities within the 890 square mile area that comprises the INEL. EPA's storm water general permit requires certain storm water pollution prevention and control measures, limited monitoring and reporting, and annual inspections. Among the conditions and requirements of this permit, the INEL must prepare and implement a storm water pollution prevention plan by October 1, 1993.

The State of Idaho issued a NOV on June 7, 1991, to DOE-ID for alleged violation of Idaho water quality regulations. DOE-ID signed a Consent Order with the State of Idaho to settle the NOV on October 7, 1992. The Consent Order, as amended, requires that DOE-ID obtain Land Application Permits for the ICPP Percolation Ponds and the ICPP Sewage Treatment Plant Infiltration Ponds by December 1, 1993.

Resource Conservation and Recovery Act (RCRA). In February 1990, DOE-ID received a Notice of Noncompliance (NON) from EPA-10 for 28 alleged violations of RCRA regulations arising from an inspection in June 1989. DOE-ID has negotiated the NON Consent Order with EPA-10, the State of Idaho, and DOE-HQ. The Consent Order was signed on March 30, 1992, and will impact operations at the Radioactive Waste Management Complex (RWMC) and the ICPP over the next 25 years.

The Consent Order resolving the hazardous waste NOV issued by the State of Idaho after a September 1990 inspection was signed on Octo- 
ber 7,1992 . The NOV consists of 23 alleged hazardous waste violations. The agreements affect the placement of Satellite Accumulation Areas (SAAs), closure of the ICPP percolation ponds, and the continued discharge of nonRCRA waste water into the percolation ponds prior to formal "clean" closure.

An RCRA NOV was received from the State of Idaho on February 9, 1993. Representatives from DOE-ID and the State of Idaho Enforcement Bureau held a meeting on March 16, 1993, and resolved all but one of the violations (investigation derived waste samples as RCRA waste). The sodium-potassium alloy $(\mathrm{NaK})$ stored in the Army Reentry Vehicle Facility Site (ARVFS) bunker, which can't be visually inspected due to high radiation levels, will be added to the NOV for resolution. Treatment of the $\mathrm{NaK}$ will be discussed during the Land Disposal Restrictions (LDR) consent order negotiation required by the Federal Facility Compliance Act (FFCA) of 1992. A Consent Order resolving the NOV is being drafted by the State of Idaho and should be received by DOE-ID by May 1993.

DOE-ID is looking for the best solution to the earthen cover storage issue. Like the ARVFS $\mathrm{NaK}$, visual inspection of the containers cannot be conducted. The issue is further clouded by the fact that the earthen covered storage was identified in the EPA NON, but due to an oversight, was not addressed in the consent order.

DOE-ID has completed the no-migration petition for the 6th and 7th Calcined Solids Storage Facilities and is waiting for DOE-HQ to submit it to EPA. With the passage of the FFCA, DOE-HQ must decide if the petition is necessary at this time. DOE-ID is working with DOE-HQ and programs to make a determination on submitting the petition.

A draft Consent Order to resolve the INEL LDR issues has been submitted to the State of Idaho and EPA-10. This starts the negotiation process. DOE-ID is taking the lead in negotiating the order, which will contain the treatment plan required by the FFCA. DOE-ID will be support- ing the National LDR Roadmapping effort and leading the development of the site-specific treatment plan, since the two must take a uniform approach and be consistent. DOE-ID is also developing the 180 Day report, which is an inventory of LDR waste streams to comply with the FFCA. This information is needed for the development of the site-specific treatment plan.

A total of 12 closure plans have been transmitted to the State of Idaho as of April 1, 1993. Six of those plans were previously submitted to the State, but additional copies were requested. Three of the remaining five plans have been approved by the State, and one closure plan has just been through the 30-day public comment period. A closure plan for the Waste Calcining Facility should be submitted to the State by the end of May 1993.

The INEL continues to replace, where necessary, and to close abandoned and out-of-service underground storage tanks (USTs). Approximately 33 USTs were closed in 1991. The INEL follows the 40 Code of Federal Regulations (CFR) 280 requirements for the replacement and closure of regulated, deferred, and exempt USTs.

National Environmental Policy Act (NEPA). Activities to ensure compliance with NEPA are ongoing at the INEL. An Environmental Impact Statement (EIS) is currently being prepared for environmental restoration and waste management activities on the INEL. A Notice of Intent to prepare the INEL Environmental Restoration and Waste Management (ER\&WM) EIS was published October 5, 1992, and scoping meetings were held during November 1992. The EIS Implementation Plan should be available to the public in late 1993.

Three Environmental Assessments (EAs) have been approved since January 1, 1992, for DOE-ID operations. Another 13 projects have been determined to require EAs, and the documents are being prepared or are in some stage of review at this time.

A Finding of No Significant Impact (FONSI) was issued in February 1991 for receipt and stor- 
age of Fort St. Vrain fuel. The State of Idaho challenged that DOE had not adequately evaluated the cumulative impacts of receipt and storage of all spent fuel at the INEL. DOE has agreed to include the impacts from the receipt and storage of the Fort St. Vrain fuel in the INEL ER\&WM EIS, but the remaining legal issues have not been resolved.

Safe Drinking Water Act (SDWA). SDWA Underground Injection Control regulations require that deep injection wells be permitted and that shallow wells be inventoried. DOE-ID has filed nine injection well permit applications with the State of Idaho. The sedimentation basins adjacent to the nonpermitted injection wells, which are used to dispose of storm water runoff, were sampled on August 17-18, 1992, and the results sent to the Idaho Department of Water Resources on January 15,1993 . The results indicated that the surface soils from the storm water retention basins and ditches did not have concentrations of metals or radionuclides greater than the range of concentrations found in local and regional soils. Volatile organic compounds were below detection limits. DOE-ID completed an inventory of the shallow injection wells at the INEL and sent an updated inventory to the State Department of Health and Welfare on July 2, 1992.

There are twelve active Public Water Systems (PWSs) within the iNEL boundaries and each is sampled routinely, including bacteriological, radiological, volatile organic compound, and organic/inorganic sampling. PWSs at the INEL are classified as Nontransient Noncommunity, but most water systems sample according to community sampling requirements. The analytical data generated by sampling is forwarded to the State of Idaho. All PWSs at the INEL are currently in compliance with all primary drinking water standards. Some contaminants have been detected in a few PWSs, but levels are below the maximum contaminant levels as set by the State of Idaho and EPA.

A continuous chlorination system is scheduled for installation in fiscal year 93 or early 94 on the water systems at TRA and the Weapons Range Complex (WRC).
Plans are under review by the State of Idaho regarding the upgrade of the deep wells at Central Facilities Area (CFA). The sampling ports for both wells are located in pits with construction deficiencies due to their being built prior to implementation of the current guidelines. The upgrade project will bring the wellhead ports above ground and correct the deficiencies.

Three waivers from standards requiring potable water supplies to be separated from sources of contamination have been submitted to the State of Idaho for review. The waivers request continued use of aboveground storage tanks which are less than 50 feet from an underground sewer line. The State has granted informal approval. Formal transmittal of the waiver will occur upon approval signature from the State Department of Health and Welfare.

Toxic Substances Control Act (TSCA). Polychlorinated biphenyls (PCBs) are being minimized at the INEL through a program of removing and retrofilling contaminated equipment. Currently there is one PCB-contaminated transformer in service at the INEL.

Radioactively contaminated PCBs have been stored at the INEL for longer than one year contrary to TSCA requirements due to a lack of technology for radioactive $\mathrm{PCB}$ treatment or disposal. In an effort to comply with TSCA, DOE-ID has submitted a strategy to DOE-HQ for negotiating an FFA/CO for the continued storage of radioactively contaminated PCBs at the INEL until a method for their treatment or disposal can be developed.

\section{Current Issues and Actions}

Five INEL current issues are described in the "Compliance Status" section which precedes this one. For information on RCRA compliance, LDRs, air litigation, the Air NOV, and the Water NOV refer to that section.

Environmental Oversight and Monitoring Agreement. A Waste Handling Plan was developed for State of Idaho INEL Oversight Program wastes generated as a result of monitoring and 


\section{ENVIRONMENTAL PROGRAM INFORMATION}

During 1992, environmental monitoring responsibilities at the INEL were performed by several organizations as assigned by DOE-ID.

Operating contractors at each INEL facility arc responsible for monitoring the effluents (releases) from their facilities and for any ambient environmental monitoring or surveillance performed within facility fences. The most extensive of these contractor surveillance programs within facilities is conducted by EG\&G Idahe The Environmental Monitoring Unit (EMU) conducts a radiological environmental surveillance program at EG\&G Idaho-operated waste management facilities at the INEL. The EMU program includes air, water, biotic and ambient radiological monitoring activities at RWMC, WERF, the Mixed Waste Storage Facility (MWSF), two contaminated surplus facilities, and control locations. Results of this surveillance program are presented each year in two annual reports written by the EMU. $^{\mathrm{a}}$

A specific division of DOE-ID, the RESL, conducts the overall environmental surveillance program at the Site by monitoring on the INEL outside facility fences, and off the INEL at locations close to and distant from the Site boundary. The USGS conducts the major portion of the ground water surveillance program.

DOE-ID program officials are responsible for oversight on compliance issues associated with operations at individual facilities.

The environmental compliance sections of this report have been prepared by the Environmental Support Division of DOE-ID. Data from the environmental surveillance program and contractor effluent monitoring programs, which com-

a. Annual Report Environmental Monitoring for EG\&G Idaho Facilities at the Idaho National Engineering Laboratory, published each year under document number EGG-2612 (year) and Drinking Water Monitoring Program Annual Report published under document number EGG-2678 (year). prise the bulk of the report, have been coordinated and summarized by RESL.

\section{Summary of Environmental Compliance Activities}

Self-Assessments. DOE-ID implements an ongoing comprehensive self-assessment program to identify and characterize environmental safety and health (ES\&H) concerns. DOE-ID's self-- assessment program includes functional and management appraisals of contractors by DOE line management, as well as internal appraisals conducted by contractors and DOE operatinglevel staff. Management performance within the DOE line organizations is also assessed.

RCRA Reports. As required by the State of Idaho, DOE-ID submitted the Idaho Hazardous Waste Generator Quarterly Reports for 1992. The reports contain information on waste generation, treatment, and disposal activities at all INEL facilities during 1992.

As required by Sections 3002 and 3004 of RCRA, DOE-ID submitted the INEL $1991 \mathrm{Haz}-$ ardous Waste Report to the State of Idaho and EPA on February 27, 1992. The report contained information on waste generation and waste minimization activities at all INEL facilities during 1991.

As required by Section 3016 of RCRA, DOE-ID submitued the INEL Section 3016 questionnaire to EPA on January 27, 1992. The report contains information on all facilities at the INEL which treat, store, or dispose of hazardous waste. There were no major changes to the questionnaire from the previous submittal.

Waste Minimization and Pollution Prevention Awareness Program. Strategies at the INEL have been developed which integrate pollution prevention into all aspects of all waste generating processes. The essential elements of the strategy are to: (a) empower organizations to develop and administer the Pollution Prevention 
Program, (b) prioritize wastestreams to reduce volume, and (c) develop a method for tracking the performance and progress of the program. Waste minimization and pollution prevention programs currently in use at the INEL are as follows:

- $\quad$ Conduct process waste assessments as part of an ongoing program to identify, screen, and analyze options to reduce the generation of waste.

- Devise a cost accounting system outlining true costs of waste generated by DOE-ID operations. The system includes short and long-term costs arising from underutilizing raw materials in wastestreams, management of generated wastes, waste disposal, and third-party liabilities for improperly disposed waste.

- Employ a Material Exchange Program to enhance sound inventory management. Inventories of unused, excess materials are processed through the Material Exchange Program for possible use by another person before being declared a waste.

- Review current methods of control for the types and quantities of materials in the site inventory. When necessary, inventory control techniques are revised or expanded to reduce inventory size and hazardous chemical use while increasing inventory turnover.

- Substitutions for hazardous solvents are examined and applied to reduce toxic emissions that have been identified as harmful to human health and ecosystems.

- $\quad$ Practice site-wide recycling of paper, wood, glass, metal, plastic, cardboard, beverage cans, and some solvents. Return vehicle, bus, and heavy equipment batteries to the vendor when no longer useful. Recover freons for reuse including completely evacuating freon shipping and storage cylinders.

- Review site equipment maintenance programs to determine whether improvements in corrective and preventive maintenance can reduce waste generation caused by equipment failure.

- Examine production processes within the site to determine whether significant source reduction of waste can be achieved by improvements in process efficiency.

Environmental Training Conducted Onsite. In December 1992, DOE-HQ came to Idaho Falls, Idaho, and provided a three-day Environmental Laws and Regulations training course for INEL employees.

In January 1993, McCoy and Associates came to Idaho Falls, Idaho, and provided a two-day RCRA training course for 500 INEL employees. In addition to these courses taught by outside groups, DOE-ID and all INEL contractors conduct extensive site- and facility-specific environmental training courses each year.

\section{Summary of RESL Environmental Surveillance Activities}

During normal operation of the reactors, fuel reprocessing plant, and other facilities at the INEL some materials are released to the environment. The environmental pathways by which radioactive and nonradioactive materials may be transported from the Site to nearby populations include passage directly through atmospheric transport or indirectly through soils, foodstuffs, or animals. Through 1992, substances originating from Site operations have not been detected in any offsite drinking water wells beyond the INEL southern boundary; thus, the aquifer is not presently a pathway to members of the public living near the Site. Although minute concentrations of Cl-36 and I-129, which may have originated at the INEL, have been detected using sophisticated techniques in some offsite observation wells, the concentrations of each were about 100,000 times below the federal drinking water standards.

The RESL Environmental Surveillance Program for the INEL and vicinity for 1992 included the collection and analysis of samples from 
potential exposure pathways (see Figure 3 ). Three basic groups of samples wer collected. Thosc collected within the INEL boundaries will be referred to as onsite or Site samples. Samples collected offsite, but near the Site boundaries, will be referred to as boundary samples or part of a group of offsite samples. Samples collected from locations considerably beyond the Site boundaries will be referred to as distant samples or part of the offsite yroup. With the exception of Craters of the Moon National Monument, the distant locations are sufficiently remote from the Site to ensure that detectable radioactivity is primarily due to natural background or sources other than INEL operations. The Craters of the Moon location is too distant to be considered a boundary location but is close enough that, occasionally, radionuclides from Site operations have been detected there at low concentrations.

Table II summarizes the RESL Environmental Surveillance Program that is required by DOE Order 5400.1.' The radiological portion of the program is considerably more extensive than the nonradiological portion, which is appropriate for operations at the INEL. As shown in Table II, air and ground water were routinely monitored for radioactivity at a number of onsite, boundary, and distant locations. Table III summarizes the USGS portion of the routine ground water monitoring program for radiological and nonradiological substances. Samples of milk, wheat, and lettuce collected from boundary and distant locations in 1992 were analyzed for concentrations of radionuclides. Environmental radiation exposure rates (cumulative from November 1991 through October 1992) were measured at onsite, boundary, and distant locations. Offsite soil samples, which are collected biennially, were collected during 1992.

Measurements at boundary and onsite locations are compared with measurements at distant locations to assess the impact of INEL operations on the environment. Concentrations of radioactive pollutants in the environment are compared to applicable standards and guides (see the section titled "Environmental Standards and Regulations") and to background and natural radioactivity. Most radioactive concentrations in this report are compared to the derived concentration guides given in DOE Order $5400.5 .^{2}$ Calculated doses are compared to DOE and EPA standards, and nonradioactive pollutants are compared to applicable EPA standards and guides.

In the text more detailed descriptions for each routine program, radioactive and nonradioactive, are given in a specific section followed by a summary of the 1992 results for the program. Most data summary tables are presented in Appen$\operatorname{dix} B$.

The section on "Quality Assurance," primarily provides information on RESL's quality control and quality assurance activities while conducting its environmental surveillance program. Brief summaries and/or references to the USGS and INEL contractors quality assurance activities are included. In addition, a brief discussion of the ISU independent environmental surveillance program and two tables with ISU and RESL 1992 data comparisons are included in this section. Appendix $\mathrm{C}$ gives a brief discussion of the statistical methods used to analyze the RESL Environmental Surveillance Program data in this report. 


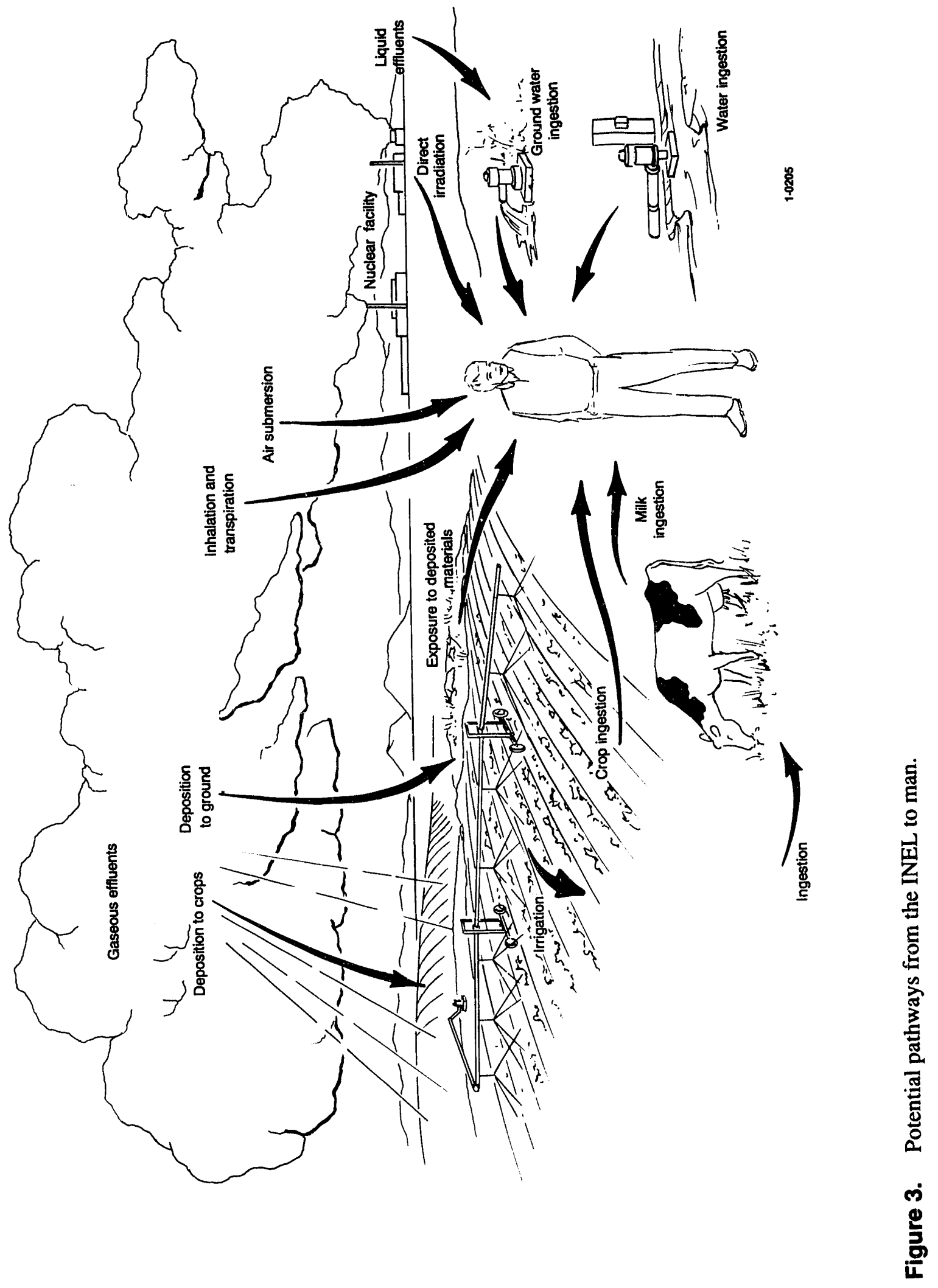


TABLE II

RESL ENVIRONMENTAL SURVEILLANCE PROGRAM SUMMARY

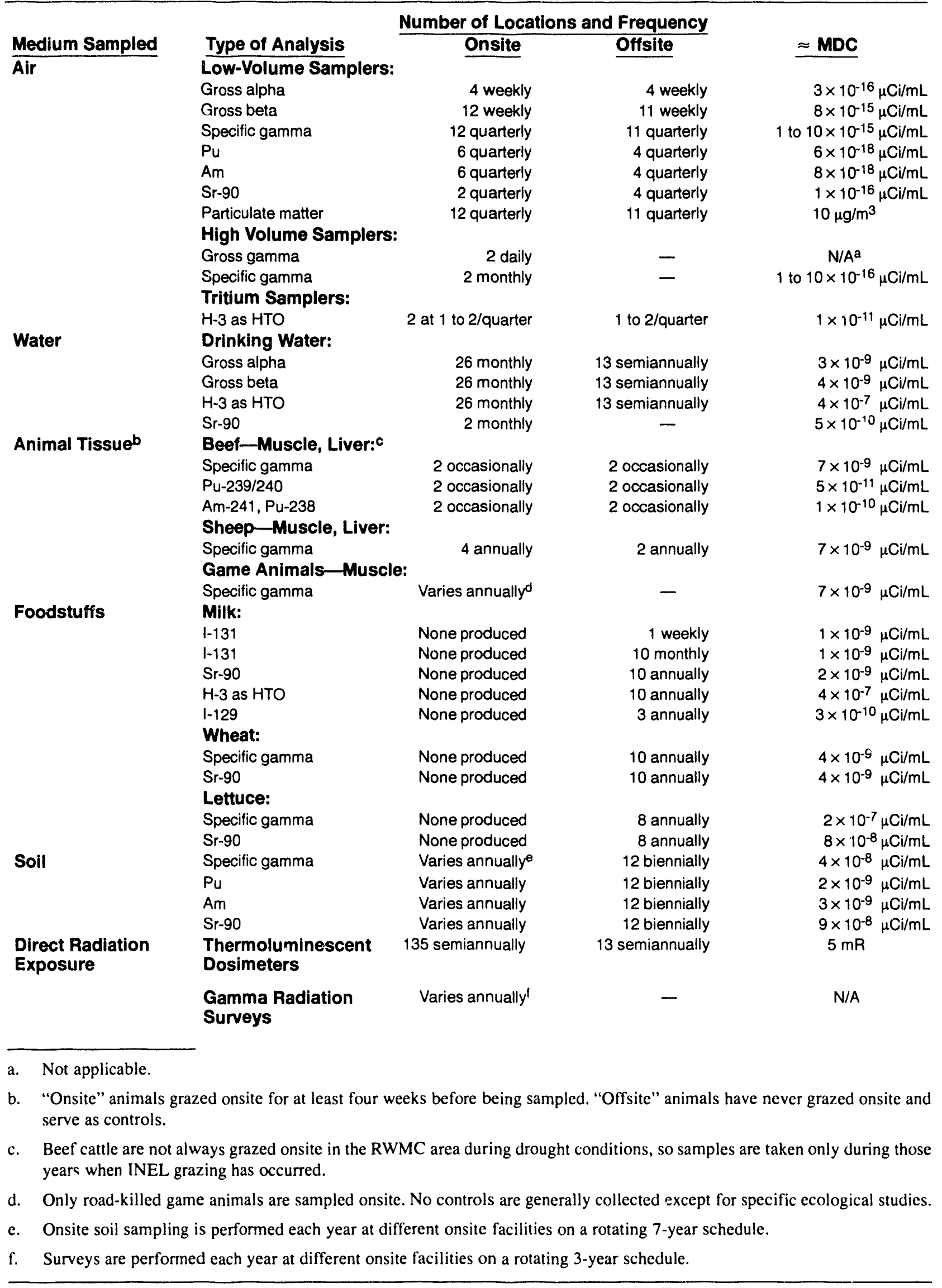




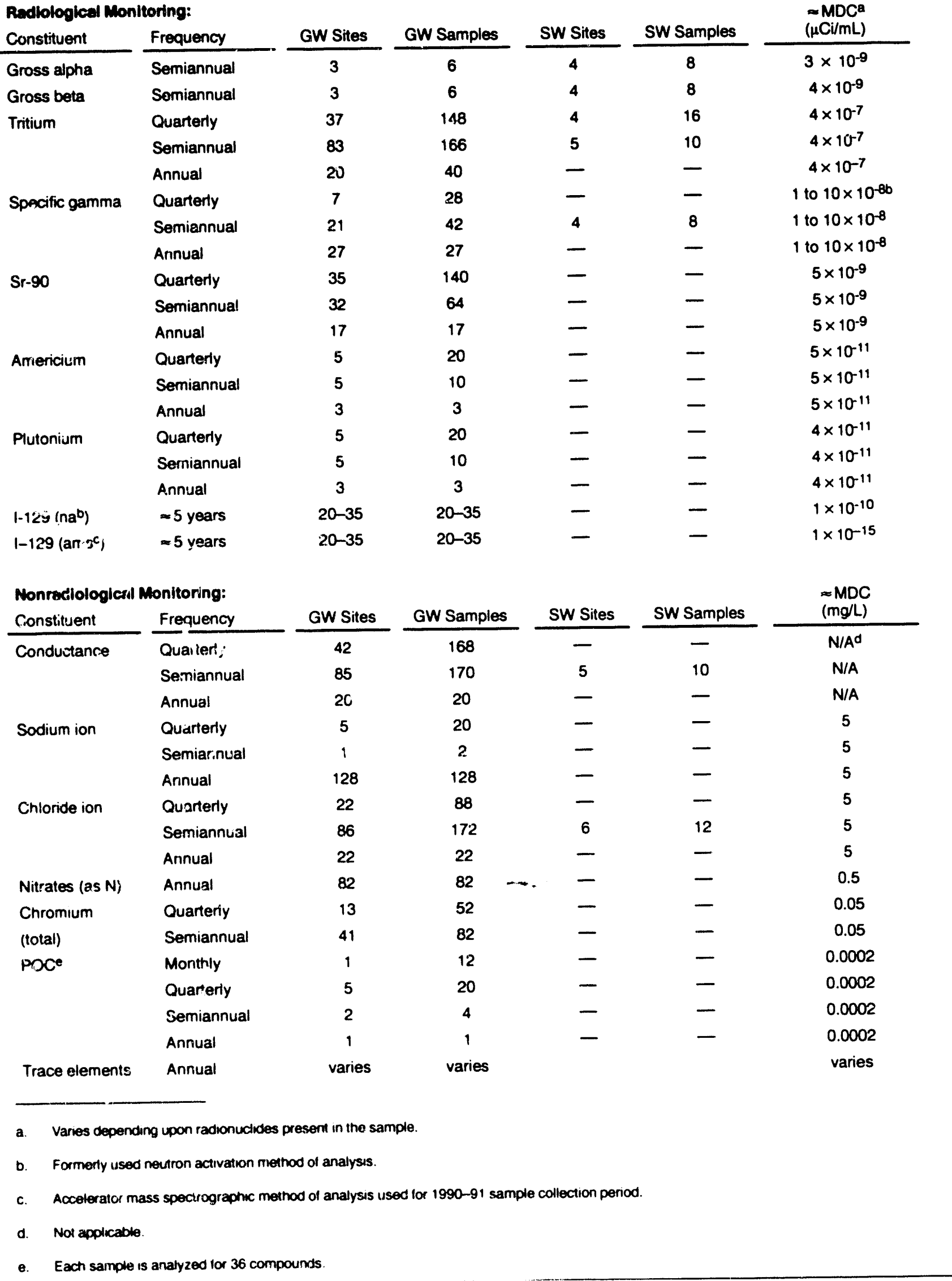




\section{ENVIRONMENTAL RADIOLOGICAL PROGRAM INFORMATION}

\section{General Compliance Information}

During 1992, DOE-ID filled the request for additional information issued by EPA-10 in 1991. Completion of this request closes the outstanding issues with EPA-10 related to NESHAPs monitoring requirements.

DOE-ID has requested all INEL contractors with monitored air emission pathways to evaluate their monitoring systems against ANSI N13.1-1969. This assessment will help document the as-built conditions of each monitoring system and provide data on how the monitor configuration may facilitate obtaining representative samples. This assessment is currently ongcing with completion expected in 1994.

DOE-ID is currently working on the 1992 NESHAPs Annual Report. This report, which is due to be submitted to EPA June 30, 1993, will provide an analysis of all radiological air emissions at the INEL during 1992.

\section{Unplanned Releases}

As reported last year, on April 2, 1992, moisture levels and temperatures inside the ICPP main stack became slightly elevated during testing of the new Liquid Effluent Treatment and Disposal (LET\&D) Project. These conditions may have prompted a very thin layer of ammonium nitrate coating the inside of the stack to begin flaking and breaking loose. Flakes approximately one inch in size and registering radiological contamination levels of 2 to 10 mrem were carried by light winds to an area northeast of the main stack and deposited on the ground. Clean up of the contamination has been completed and none was detected outside the ICPP boundaries.

\section{Summary of RESL Environmental Surveillance Program Results}

\author{
Air Sampling.
}

Low-volume Samplers. Airborne particulate radioactivity is monitored continuously by a network of 12 air samplers within the INEL and 11 air samplers outside the Site boundaries at the locations shown in Figure 4. Locations of onsite samplers were selected to give adequate coverage in the event of facility releases of radioactivity. Seven offsite air samplers are located near the Site boundary in communities, when possible, or at noncommunity locations when necessary to encompass the perimeter of the Site. Four samplers are located at the distant communities of Blackfoot, Craters of the Moon National Monument, Idaho Falls, and Rexburg to provide background measurements for comparison with data from boundary or onsite samplers that might be affected by INEL operations. The whole network provides comprehensive surveillance of particulate atmospheric radioactivity and makes it possible to differentiate INEL releases from worldwide fallout and long-lived natural radioactivity.

Each air sampler maintains an average air flow of about $50 \mathrm{~L} / \mathrm{min}\left(2 \mathrm{ft}^{3} / \mathrm{min}\right)$ through a set of filters consisting of a membrane filter (Gelman Model V -1200$)^{b}$ followed by a charcoal cartridge filter (Radeco Model BG-300). ${ }^{b}$ The filters are 99\% efficient for airborne particulate radioactivity and airborne iodides.

b. Use of commercial product names is for accuracy in technical reporting and does not constitute endorsement of the product by the United States Government. 
Craters of the Moon National Monument
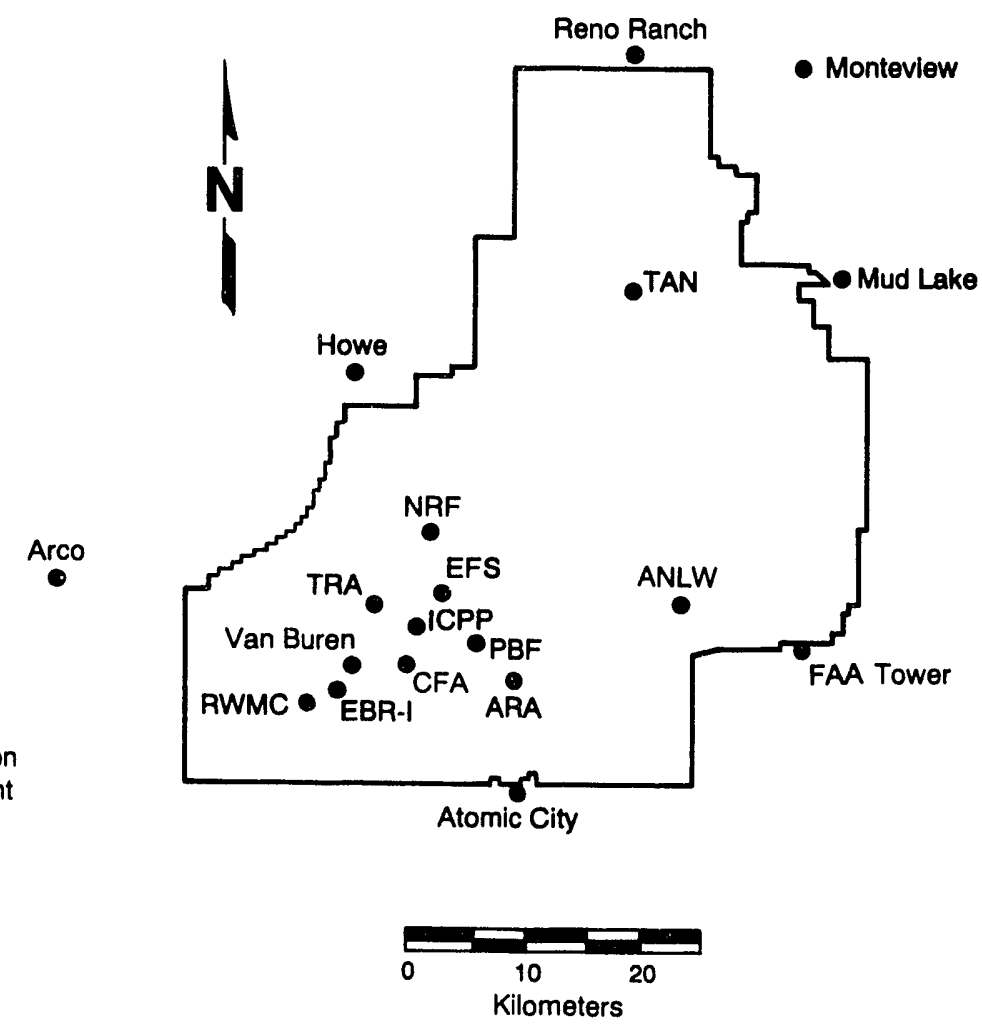

\footnotetext{
- Low-volume Air Samplers
}
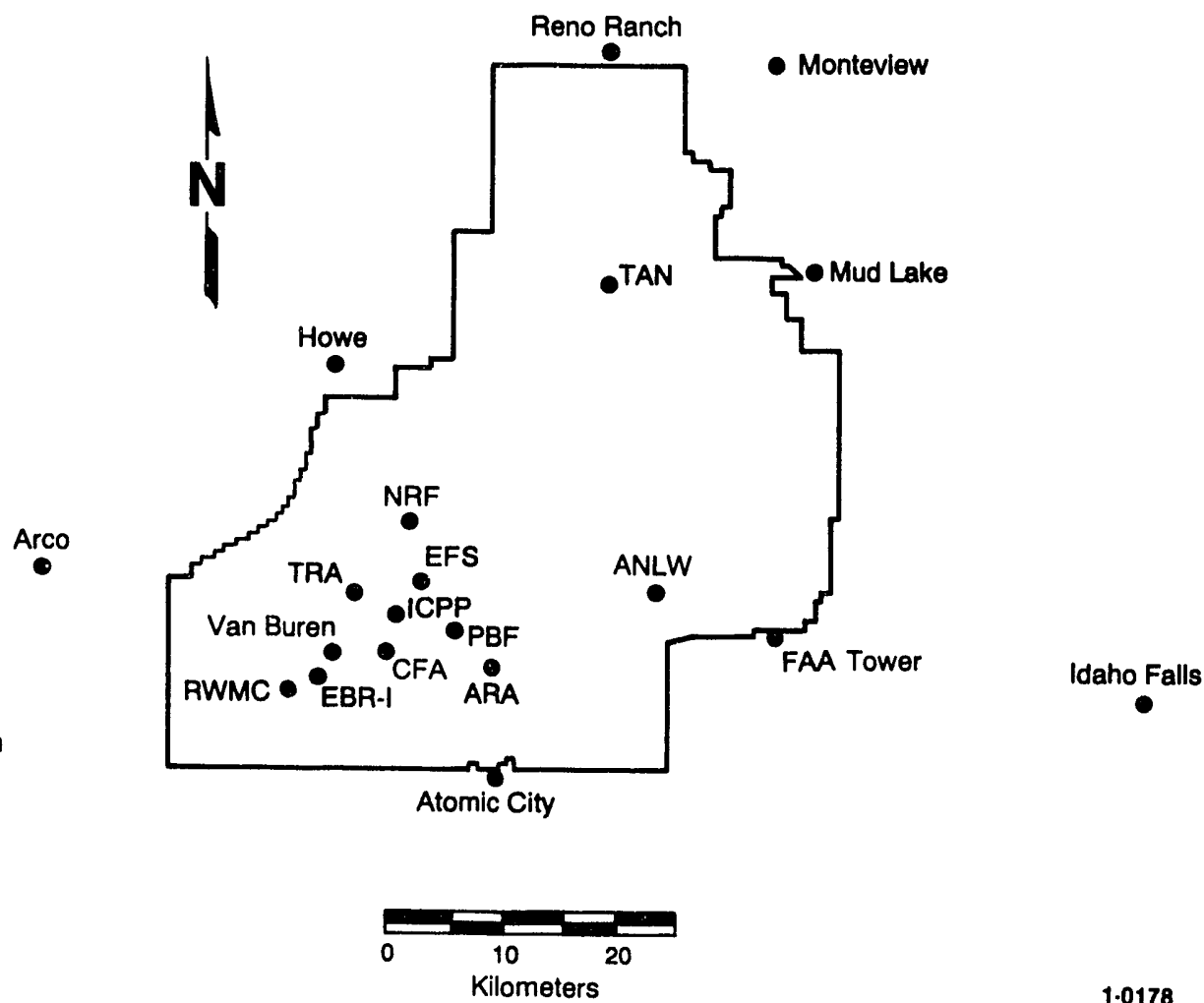

1.0178

\section{Blackfoot}

Figure 4. INEL Site and vicinity air sampling network.

Gross Alpha, Gross Beta, Gross Gamma. The particulate filters from the low-volume air samplers are collected weekly, and analyzed after waiting a minimum of four days to allow the naturally occurring, short-lived radon and thoron daughters to decay. "Gross" (nonspecific) analyses of the airborne particulates trapped on the membrane filters are performed weekly, and the activity detected is termed "gross alpha" or "gross beta" to differentiate these results from analyses for specific radionuclides. Because the distant community group is small, a low concentration at only one or two locations can cause the statistical test to indicate that onsite mean concentrations are significantly higher than those of the distant community group. This variable alone can make interpretation of results of nonspecific gross alpha or beta measurements difficult. Therefore, when interpreting air sampling data, RESL relies more on the results and comparisons of specific nuclide data rather than on gross alpha and beta concentrations. Furthermore, the source of the radioactivity can be determined more easily from the specific nuclide concentrations than from the nonspecific "gross" concentrations. Specific nuclide analyses are also more sensitive than gross alpha and gross beta analyses.

Analyses for gross alpha activity are performed on eight selected filters: Blackfoot, Craters of the Moon, Arco, Mud Lake, ANL-W, the Experimental Field Station (EFS), RWMC, and TAN. Gross alpha concentrations are sometimes greater at the distant location of Blackfoot than at the other locations because of non-INEL sources. Gross alpha data for 1992, presented in Appen$\operatorname{dix}$ B, Table B-1, shows the mean of the onsite group is slightly lower than the means of the offsite groups. The differences between the group means are not statistically significant, and would appear to verify that operations at the INEL are not responsible for the gross alpha activity detected on any of the filters. 
The charcoal cartridges from each sampler are screened weekly for I-131 activity with a large well-type, thallium-activated, sodium iodide $[\mathrm{NaI}(\mathrm{Tl})]$ detector. The filters are counted either individually or as a stack of four filters. The counting efficiency was experimentally derived by the RESL analytical laboratory specifically for this $I-131$ screening procedure. The screening result represents the maximum $\mathrm{I}-131$ activity in $\mu \mathrm{Ci} / \mathrm{mL}$, assuming all gross gamma activity observed is attributable only to I-131. If the activity measured exceeds an action level of about $1 \times 10^{-12} \mu \mathrm{Ci} / \mathrm{mL}$, or if an INEL facility release is suspected, followup analysis by gamma spectrometry using a High-Purity Germanium detector is done to determine the actual I-131 component, if any.

Analysis for gross beta activity is performed on each membrane filter from all 23 locations in a low background beta counter. If the gross beta activity on a filter exceeds an action level of $1 \times 10^{-12} \mu \mathrm{Ci} / \mathrm{mL}$, or if a Site release is suspected, the filter is analyzed by gamma spectrometry.

The gross beta activity on the membrane filters is determined weekly for samplers at each location as a screening technique to give timely information in the event of INEL releases or worldwide fallout. This information may be difficult to interpret, however, because of local variations in beta concentrations at any given time or location. Any of several factors may be responsible for the variations observed. Examples of these factors include dust or soot loading on individual filters, varying concentrations of natural radioactivity at different locations, and uneven distribution of worldwide fallout radioactivity as a result of diverse local meteorological conditions. A common problem near the INEL is that wood smoke loading of filters in or near communities sometimes occurs during cold weather. When an individual filter's pores are plugged early in the week, abnormally low gross beta concentrations often result.

The 1992 results of gross beta analyses of particulates on the membrane filters are summarized in Appendix B, Table B-2. The gross beta activity measured at each onsite and boundary location was statistically compared to gross beta activity measured at the group of distant locations for each month and for the entire year. Appendix B, Table B-3, shows 1992 results of these monthly and annual statistical comparisons of boundary and Site locations to the distant community group mean gross beta activity. Site operations information and meteorological data were considered in each case where a location or group was statistically greater than the distant location group. A statistical difference was found in about $11 \%$ of the comparisons, but none of these appeared to be due to Site operations.

During January 1992, two boundary, four onsite locations, and both the onsite and boundary group mean concentrations were statistically higher than the distant group mean. Annual mean concentrations at several of these locations and the onsite and boundary group annual means were also higher than the distant location annual group mean. After analysis of INEL release data and examination of the results of specific radionuclide analyses reported in the next section, no evidence could be found to indicate that the higher gross beta concentrations at any of these locations during any 1992 time period were due to manmade radionuclides or to Site operations.

The average monthly concentrations of gross beta activity for onsite, boundary, and distant location groups are shown in Figures 5 and 6 for 1984-1992. The figured bar represents the time of the Chernobyl accident after which gross beta activity peaked dramatically. In recent years, there appears to be a small pattern of variation with slightly higher concentrations occurring near the beginning and the end of most years. Reasons for this variation are most likely related to meteorological conditions.

Specific Radionuclides. Specific radionuclide analyses are more sensitive indicators than gross beta analyses of concentrations of manmade radionuclides in air. Therefore, the membrane filters of the low-volume samplers are composited according to location at the end of each quarter, and all composites are analyzed for specific radionuclides by gamma spectrometry. 
Selected composites are then submitted for analyses for alpha-emitting radionuclides or $\mathrm{Sr}-\mathbf{9 0}$. The analyses for alpha-emitting nuclides use chemical separation techniques followed by alpha spectrometry; for $\mathrm{Sr}-90$, the chemical separation is followed by beta counting. Because both of the follow-up analyses consume the entire sample, only one of the two types can be performed on a given composite. The composites from one distant location and four onsite locations are analyzed each quarter for specific alpha-emitting radionuclides. The composites from another distant location and four other onsite locations are analyzed each quarter for $\mathrm{Sr}-\mathbf{9 0}$. In addition, six offsite and four onsite location composites are analyzed on alternating schedules, giving a total of ten rotating analyses. (Five composites are submitted for alpha-emitting nuclides and five for $\mathrm{Sr}-90$ one quarter; during the next quarter, the groups are reversed and submitted for the other type of analysis.)

The quantity and identity of radionuclides released from INEL facilities are reported quar- terly in the Radioactive Waste Management Information System (RWMIS) report. ${ }^{c}$ Whenever any question exists as to the impact of Site operations on the environment, results of the specific radionuclide analyses are compared to release data from the RWMIS reports in an attempt to determine the source of the detected material.

Results of the quarterly specific radionuclide analyses of membrane filter composites are summarized in Appendix B, Table B-4. Beryllium-7, a naturally occurring radionuclide produced by the interaction of cosmic radiation and nitrogen in the atmosphere, is excluded. Although $\mathrm{Be}-7$ is also a manrivste radionuclide produced at some National Laboratories, it is not a significant product of the processes at the INEL. Radionuclides included in Table B-4 are those that could potentially be released from INEL operations.

c. Preliminary INEL Radioactive Waste Management Information System data for 1992. 

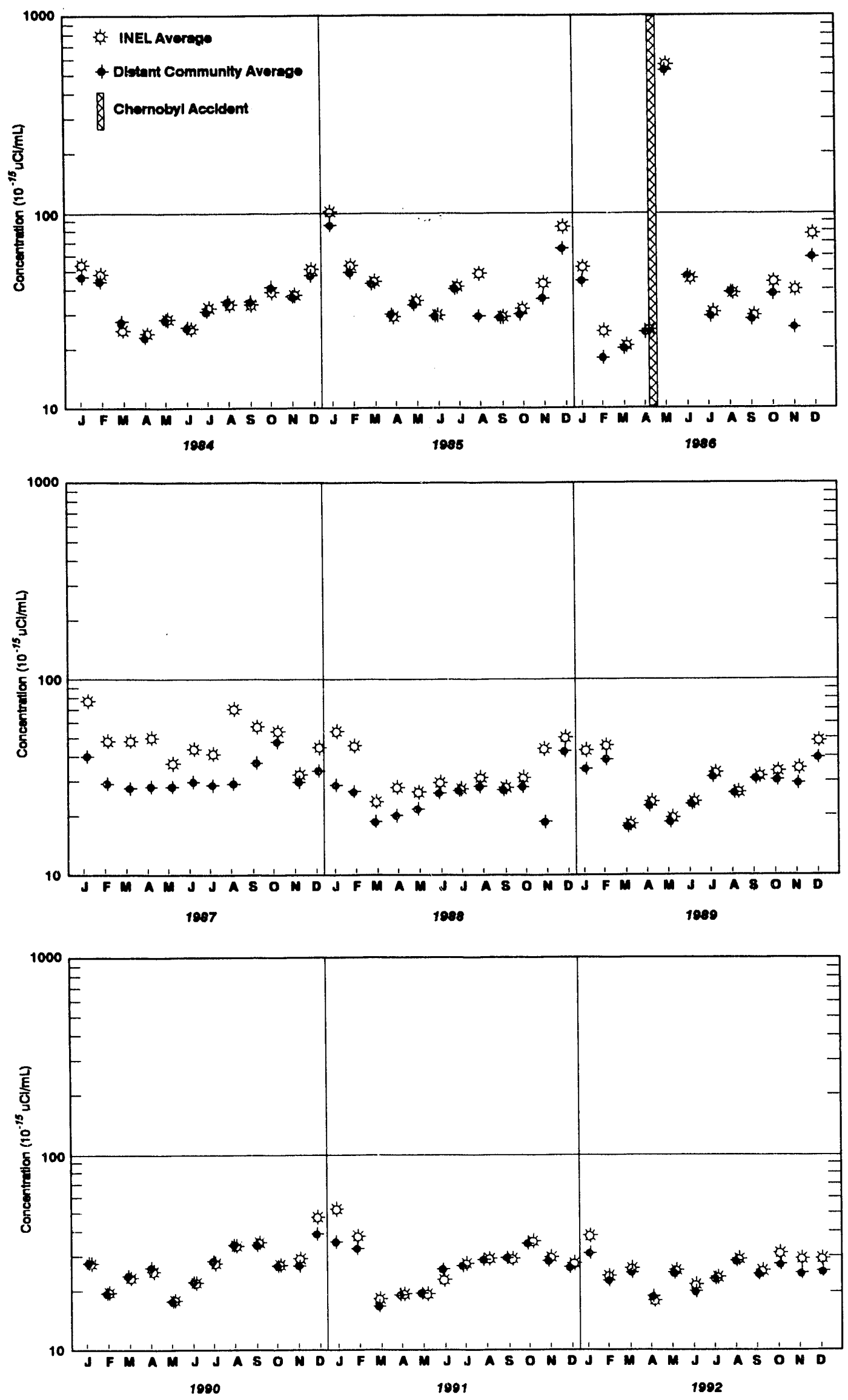

Figure 5. Site and distant gross beta concentrations in air. 

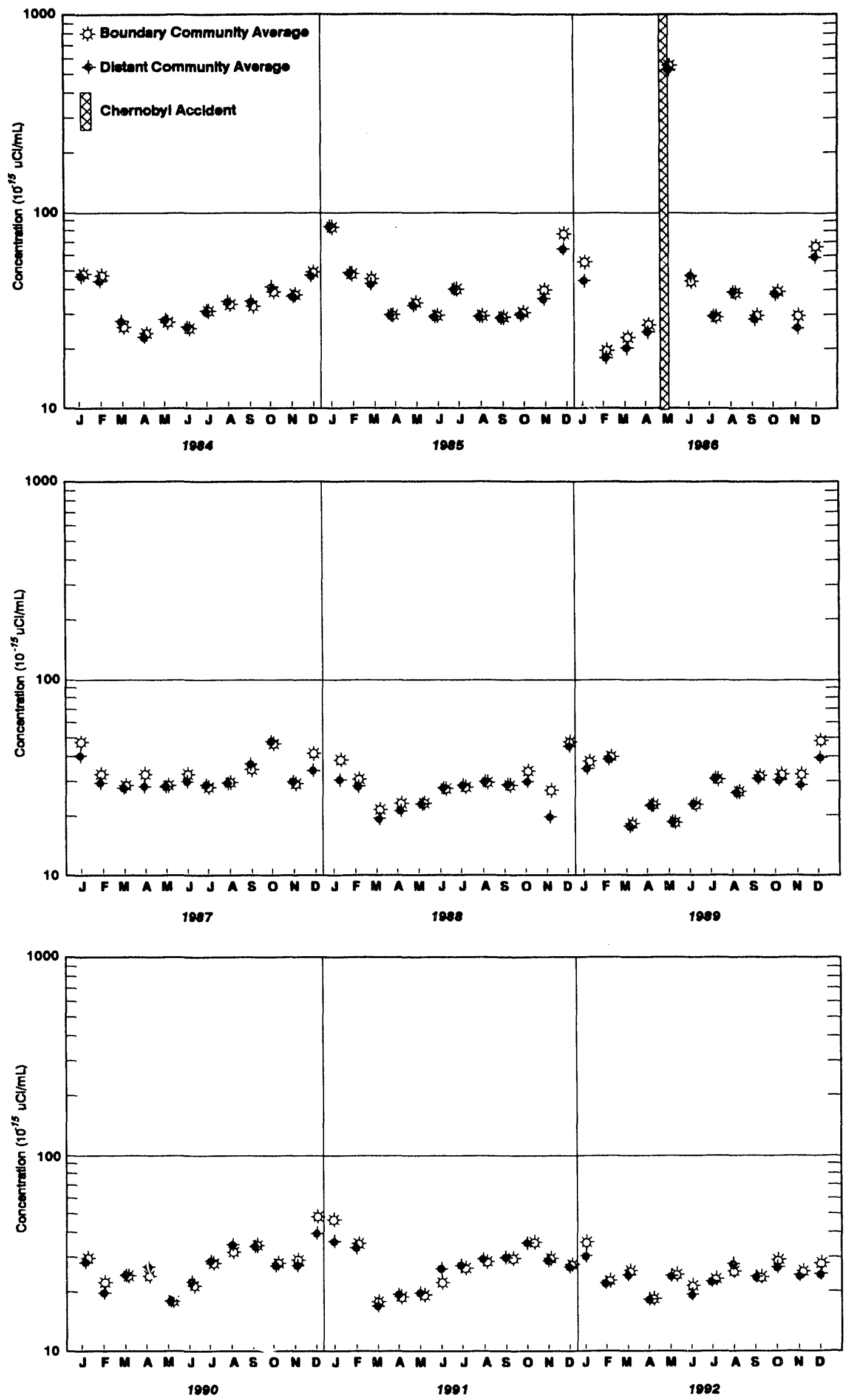

Figure 6. Boundary and distant gross beta concentrations in air. 
One gamma-emitting radionuclide $(\mathrm{Ce}-141)$ was measured at a concentration of $2.0 \pm 1.8 \times 10^{-15} \mu \mathrm{Ci} / \mathrm{mL}$ at Van Buren Boulevard (VANB) during the third quarter 1992. This concentration and those throughout this report that include uncertainties are presented in the format "result $\pm 2 \mathrm{~s}$ " where " $\mathrm{s}$ " represents the estimated random analytical uncertainty. The $2 \mathrm{~s}$ value approximates the $95 \%$ confidence interval for most analyses. When a reported concentration is near the minimum detectable concentration and the result lies between $2 \mathrm{~s}$ and $3 \mathrm{~s}$, detection of a radionuclide is questionable. Therefore, it is difficult to draw firm conclusions about the presence or source of the radioactivity. See Appendix C for a more detailed description of this problem.

Strontium-90, a nuclide deposited on soil worldwide as a result of fallout from nuclear weapons tests, is often detected at concentrations near the minimum detectable concentration on filters from both onsite and offsite samplers, most likely as a result of windblown dust resuspension.

In 1992, $\mathrm{Sr}-90$ was reported at a concentration near the minimum detectable concentration at EFS during the first quarter and at two distant, two boundary, and one onsite location during the fourth quarter. All reported concentrations were in the range of questionable detection where the result is less than three times the analytical uncertainty (see Appendix C). If it is assumed that Sr-90 was present on the filters, the highest annual mean $\mathrm{Sr}-90$ concentration for any of the six locations was less than $0.002 \%$ of the DOE annual derived concentration guide for radiation protection of the public.

Plutonium-239/240 was reported at the Craters of the Moon National Monument during the first quarter of 1992 at a concentration of $3 \pm 2 \times 10^{-18} \mu \mathrm{Ci} / \mathrm{mL}$. During the second quarter, a concentration of $5 \pm 3 \times 10^{-18} \mu \mathrm{Ci} / \mathrm{mL}$ was reported at Power Burst Facility (PBF) and of $6 \pm 3 \times 10^{-18} \mu \mathrm{Ci} / \mathrm{mL}$ at VANB. These concentrations are near the minimum detectable concentration and are most likely due to resuspended dust from worldwide fallout.
Comparisons of the onsite group mean concentrations to the boundary and distant communisy group means revealed no statistical differences for any manmade radionuclides detected during 1992.

Tritium. Samplers for tritium in water vapor in the atmosphere are located in Idaho Falls and at the EFS and VANB locations on the INEL. In these samplers, air is passed through a column of silica gel at a rate of $0.3 \mathrm{~L} / \mathrm{min}\left(0.65 \mathrm{ft}^{3} / \mathrm{h}\right)$. Water vapor in the air is adsorbed by the gel in the column, and tritium concentrations are then determined by liquid scintillation counting of the water extracted from the silica gel columns at the end of the sampling period.

During 1992, a total of 15 samples were collected at the three locations. The January 3 to February 28, 1992, sample collected at EFS contained a detectable concentration of tritium at $8 \pm 2 \times 10^{-12} \mu \mathrm{Ci} / \mathrm{mL}$. Of the remaining $14 \mathrm{sam}$ ples, one was lost during analysis, and 13 had no measurable concentrations of tritium. Examination of Site facility releases and meteorological information showed no clear evidence that the presence of tritium in air at EFS was due to INEL operations; however, it is tentatively assumed that it could be since samples from the background location at Idaho Falls did not show detectable concentrations of tritium during the year. The annual mean tritium concentration at EFS was less than $0.0008 \%$ of the annual derived concentration guide for radiation protection of the public.

Tritium from airborne water vapor may also be deposited on the earth's surface in rain and snow samples. Precipitation samples are routinely collected at CFA, EFS, and Idaho Falls and are analyzed for tritium. None of the 38 precipitation samples collected in 1992 contained detectable concentrations of tritium.

Krypton-85. In the past, RESL monitored $\mathrm{Kr}-85$ at one Site location, CFA. The samples were collected in large Tedlar bags, compressed biweekly, and shipped each month to the EPA Environmental Monitoring Systems Laboratory in Las Vegas (EMSL-LV) for analysis. However, 
RESL discontinued operation of this sampler in March 1992 because costly changes to upgrade the sampling system were needed to comply with safety regulations. Furthermore, changes in future plans for operation of the ICPP, the major release point for $\mathrm{Kr}-85$, significantly decreased the need for this type of sampling.

Except during certain fuel reprocessing operations at ICPP, the $\mathrm{Kr}-85$ levels measured at CFA were typical of levels found in the western United States by EMSL-LV. The annual average concentration of $\mathrm{Kr}-85$ for 1991 (the last complete year of data) was $2.8 \times 10^{-11} \mu \mathrm{Ci} / \mathrm{mL}$, which is $0.0009 \%$ of the derived concentration guide for radiation protection of the public. (See the section entitled "Environmental Standards and Regulations.")

\section{Radiological and Environmental Sciences Laboratory (RESL) Water Sampling.}

General. No streams or rivers flow from within the INEL to locations outside the boundaries. Therefore, water sampling at the Site is limited to ground water monitoring. Offsite community drinking water is also sampled, plus surface water samples from the Snake River, which flows at a considerable distance outside the Site boundaries, and a few surface springs in the Twin Falls, Idaho, area. The Snake River Plain aquifer, which lies beneath the INEL Site, serves as a primary source for drinking water and crop irrigation in the Snake River Basin.

Onsite and offsite water samples are collected routinely to monitor the movement of waste substances, both radioactive and nonradioactive, through the aquifer. Onsite drinking water samples are collected monthly from production (drinking water) wells and/or distribution systems in use at active Site facilities. RESL collects drinking water from boundary and distant communities and Snake River water samples semiannually and submits them for radionuclide analyses, (see Table II). Approximate locations of RESL offsite water sample collection sites are shown in Figure 7, along with locations of four of the observation wells beyond the southern and western Site boundaries that the USGS samples routinely. During 1992, three surface water locations in the Magic Valley area (Twin Falls and points west) and two from communities (Snoshone and Minidoka) were sampled quarterly. Each RESL sample was collected simultaneously with one by the ISU Environmental Monitoring Program for comparison to their independent environmental surveillance program. RESL data are compared to ISU data for these water samples in the section titled "Quality Assurance," of this report. ISU also splits some samples from onsite wells with the USGS.

In addition to the production well monitoring performed by RESL, the USGS conducts an extensive ground-water surveillance program on the INEL Site. A description of the USGS portion of the water surveillance program and maps showing locations of their sampling wells are included in the section titled "Ground-Water Surveillance Program Information."

Gross Alpha, Gross Beta. Each RESL water sample is submitted for gross (nonspecific) analyses for alpha and beta-emitting radionuclides that might be present in the water. For gross alpha analysis, a portion of the sample is evaporated on a stainless steel planchet and counted with a scintillation counter system. For gross beta activity, a portion is evaporated and counted in a low-background beta counter. The minimum detectable concentrations for gross alpha and gross beta are $3 \times 10^{-9}$ and $4 \times 10^{-9} \mathrm{mCi} / \mathrm{mL}$, respectively, or about $10 \%$ and $4 \%$ of the DOE derived concentration guides for radiation protection of the public (see the section entitled "Environmental Standards and Regulations"). These minimum detectable concentrations are also $20 \%$ and $8 \%$, respectively, of maximum contaminant levels for community drinking water listed by the EPA in 1992. 


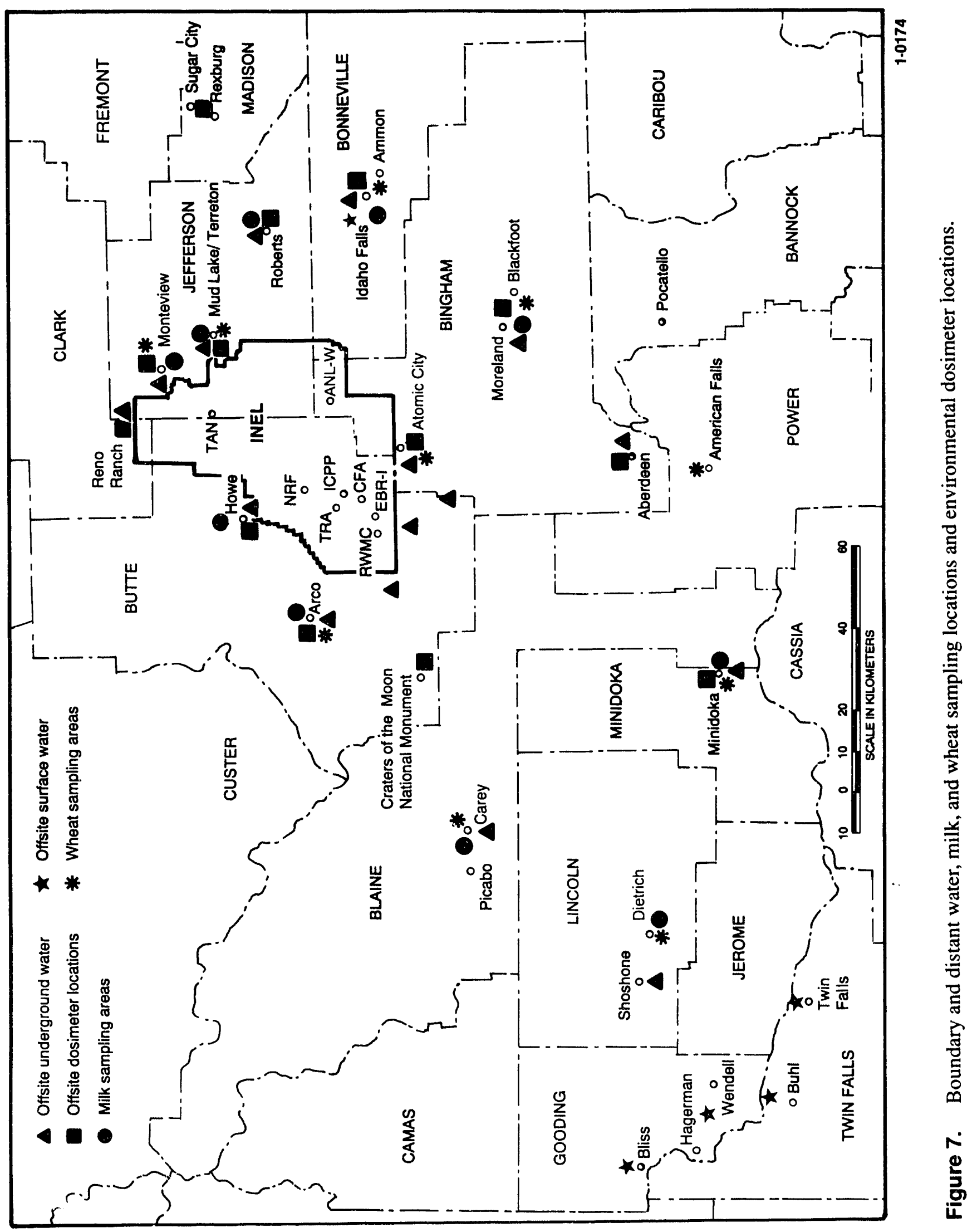


The DOE Order $5400.1^{1}$ requiring preparation of this report recommends using units of $\mu \mathrm{Ci} / \mathrm{mL}$ for concentrations of radionuclides in water. However, 40 CFR 141 gives the EPA maximum contaminant levels in units of $\mathrm{pCi} / \mathrm{L}$. For the reader's convenience, concentrations of radionuclides in water samples will be shown with exponents that allow easy conversion to the EPA units:

$1 \times 10^{-9} \mu \mathrm{Ci} / \mathrm{mL}=1 \mathrm{pCi} / \mathrm{L}$

$1 \times 10^{-6} \mu \mathrm{Ci} / \mathrm{mL}=1000 \mathrm{pCi} / \mathrm{L}$.

Approximately $8 \%$ of all RESL drinking water samples collected in 1992 contained detectable concentrations of gross alpha activity. Two of the 40 boundary and distant water samples and 25 of the 310 Site drinking water samples collected and analyzed by RESL in 1992 contained detectable gross alpha activity. All detectable concentrations were lower than $3 \pm 2 \times 10^{-9} \mu \mathrm{Ci} / \mathrm{mL}$ and represent measurements near the minimum detectable concentration. At these low concentrations, it is difficult to draw firm conclusions about the presence of the radioactivity (see Appendix C). Annual gross alpha average concentrations for the 1992 samples at all locations were less than $2 \times 10^{-9} \mu \mathrm{Ci} / \mathrm{mL}$, which is within the expisted concentration range for naturally occurring alpha activity in the aquifer underlying the INEL and surrounding areas. ${ }^{3}$ According to USGS reports, 4,5 alpha-emitting wastes from Site operations have not migrated far from their entrance into the aquifer near ICPP. Therefore, the offsite gross alpha activity is unlikely to be due to migration of wastes from Site operations, and all onsite drinking water wells lie outside the migration plumes for alpha-emitting nuclides. Gross alpha concentrations in all samples were less than the EPA community drinking water standard for gross alpha activity of $15 \mathrm{pCi} / \mathrm{L}$ $\left(15 \times 10^{-9} \mu \mathrm{Ci} / \mathrm{mL}\right)$.

Seventeen of the 310 Site samples and 3 of the 40 boundary and distant samples (about $6 \%$ of all samples) showed detectable gross beta concentrations at $8 \pm 4 \times 10^{-9} \mu \mathrm{Ci} / \mathrm{mL}$ or lower, that is, near the minimum detectable concentration (see Appendix C). Annual averages for gross beta activity at all locations were below the EPA community drinking water standard of $50 \mathrm{pCi} / \mathrm{L}$ $\left(50 \times 10^{-9} \mu \mathrm{Ci} / \mathrm{mL}\right)$.

Natural radioactivity is found in the Snake River Plain aquifer in areas upgradient, parallel to, and distant from the INEL Site. The natural radioactivity is the probable source of the presence of low concentrations of gross alpha and gross beta activity.

Specific Radionuclides. Tritium analyses are routinely performed on the water samples collected by RESL; and $\mathrm{Sr}-90$ analyses are performed each month on samples from drinking water wells in the ICPP area, because two of these wells lie within the $\mathrm{Sr}-90$ waste plume as determined by the USGS. Figures 8 and 9 taken from a USGS report ${ }^{5}$ illustrate the approximate extent of the tritium and $\mathrm{Sr}-90$ waste plumes. A waste plume is defined as the three-dimensional distribution of a selected contaminant in the water of the aquifer and perched water bodies originating from INEL facilities. Plume maps, such as those shown in Figures 8 and 9, are two-dimensional representations constructed from a few points of data from well samples and from knowledge about aquifer movement and other hydrological parameters. In Figures 8 and 9 , the $0.5-\mathrm{pCi} / \mathrm{mL}$ and $5-\mathrm{pCi} / \mathrm{L}$ concentration contours, respectively, approximate the locations of detectable concentrations for each plume. Both plumes were inside the Site boundary in 1988 when the figures were published by the USGS.

Concentrations of tritium are determined by using a liquid scintillation counter. Strontium-90 is separated from the sample chemically and after an ingrowth period; its $\mathrm{Y}-90$ decay product is separated chemically and counted in a low-background beta counter to determine the amount of Sr-90 initially present in the sample. The minimum detectable concentrations for tritium and Sr-90 are $400 \times 10^{-9}$ and $0.5 \times 10^{-9} \mu \mathrm{Ci} / \mathrm{mL}$, or about $0.02 \%$ and $0.05 \%$, respectively, of the DOE derived concentration guides for radiation protection of the public. These minimum detectable concentrations are about $2 \%$ and $6 \%$, respectively, of maximum contaminant levels for community drinking water listed by the EPA in 1992 . 


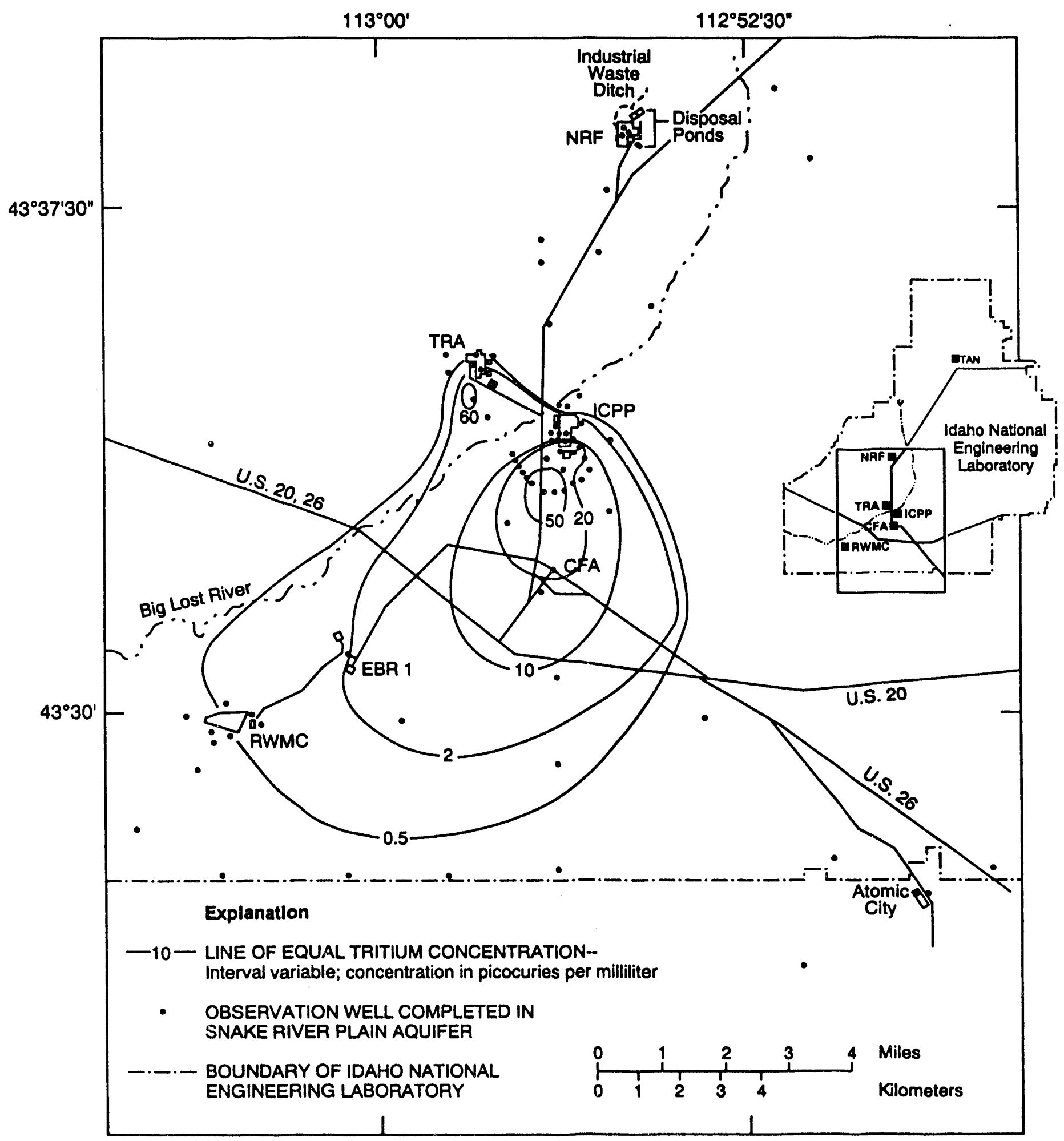

Figure 8. Distribution of tritium in the Snake River Plain Aquifer in the southcentral part of the INEL, 1988. 5 


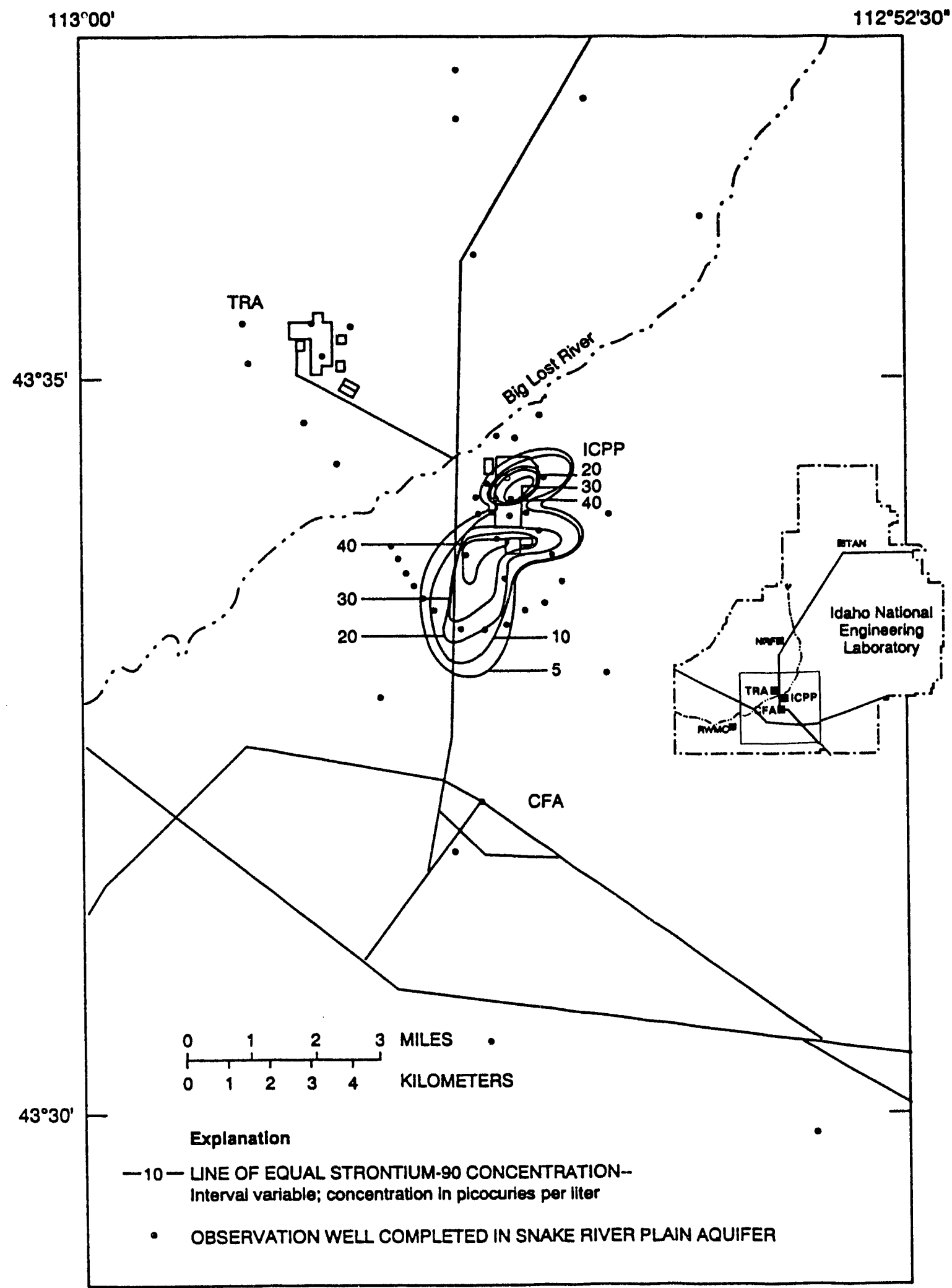

Figure 9. Distribution of $\mathrm{Sr}-90$ in the Snake River Plain aquifer in the southcentral part of the INEL, $1988 .^{5}$ 
None of the boundary or distant community water samples contained detectable concentr:tions of tritium. Some samples from onsite wells that lie within the tritium plume consistently contain detectable concentrations of tritium. Current data from these wells are presented in Appendix B, Table B-5, and data for the past five years are presented graphically in Appendix B, Figure B-1. Samples from two of the ICPP production wells sometimes have detectable concentrations of $\mathrm{Sr}-90$. These data are also presented in Table B-5. The highest annual average concentration of tritium in Site drinking water (at CFA) is $0.9 \%$ of the derived concentration guide for radiation protection. For $\mathrm{Sr}-90$, the highest annual average concentration (at ICPP) was $0.07 \%$ of the derived concentration guide.

The USGS detected tritium in water samples from some of the observation wells just inside the southern Site boundary for the first time in 1983, but it has not been detected in samples collected from those wells since January 1986. In the nearest offsite well, which is about $0.8 \mathrm{~km}(0.5 \mathrm{mi})$ south of the Site boundary, tritium has never been detected above the minimum detectable concentration of $400 \times 10^{-9} \mu \mathrm{Ci} / \mathrm{mL}$.

Strontium-90 analyses were above the minimum detectable concentration $\left(5 \times 10^{-9} \mu \mathrm{Ci} / \mathrm{mL}\right)$ only for those samples collected within $3.2 \mathrm{~km}$ $(2.0 \mathrm{mi})$ of the former disposal well at ICPP, or approximately $9.8 \mathrm{~km}(6.1 \mathrm{mi})$ inside the nearest Site boundary. As seen in Figure 8, those wells lie within the Sr-90 plume. Isotopes of cesium and plutonium are even less mobile in the aquifer than strontium, and the locations at which detectable concentrations of these isotopes can be detected are still near the point of entrance into the aquifer.

The effective dose equivalent from drinking water to a worker at CFA was calculated. CFA was selected because the tritium concentrations found in these wells are the highest of any drinking water wells. The 1992 effective dose equivalent to a CFA worker was based on:
- $\quad$ Average tritium concentrations for CFA \#1 and CFA \#2 for 1992 as shown in Appendix B, Table B-5

- Water usage information for 1992 showing CFA \#2 was used for approximately $88 \%$ of drinking water, and CFA \#1 was used for $12 \%$

- Data from a 1990-91 USGS study for I-129 using the accelerator mass spectrographic analytical technique indicated that water from CFA \#I contained I-129 at a concentration of $0.24 \pm 0.10 \times 10^{-9} \mu \mathrm{Ci} / \mathrm{mL}$ and water from CFA \#2 had a concentration of $0.10 \pm 0.06 \times 10^{-9} \mu \mathrm{Ci} / \mathrm{mL}$. For perspective, the proposed EPA drinking water standard for $\mathrm{I}-129$ is $21 \times 10^{-9} \mu \mathrm{Ci} / \mathrm{mL}$. $^{6}$

For the 1992 dose calculation, the assumption was made that each worker's total water intake came from the CFA drinking water distribution system. This assumption actually overestimates the dose because workers typically consume only about half their total intake during working hours, and they typically work only 240 days rather than 365 days per year. The estimated effective dose equivalent to a worker from consuming all drinking water at CFA during 1992 was $0.8 \mathrm{mrem}$ $\left(8 \times 10^{-3} \mathrm{mSv}\right)$. This is clearly below the EPA standard of 4 mrem for community drinking water systems.

\section{Foodstuff Sampling.}

General Information. Milk, wheat, and leafy garden lettuce are sampled annually. Muscle and liver samples from sheep are a!so collected annually. Muscle and liver samples from beef cattle were sampled biennially in the past, but the grazing areas near the RWMC have not been used in recent years due to drought conditions. Because they are part of the typical American diet, all these foodstuffs could be pathways to the public for radionuclides from fallout or from INEL operations. Boundary areas are compared to distant areas to assess possible impacts from INEL operations. Milk and wheat sampling locations are shown in Figure 7. Lettuce was collected at 
Arco, Atornic City, Blackfoot, Carey, Howe, Idaho Falls, Mud Lake, and Pocatello.

Milk-Milk samples (1 49 totai) were collected from dairies and single-iamily milk cows in the INEL vicinity. Samples are normally collected monthly except in Idaho Falls, where a sample is collected weekly. All milk samples are passed through an anion exchange resin, which is then analyzed for $1-131$ by gamma spectrometry. Milk from each location is analyzed for $\mathrm{Sr}-90$ and tr:tium annually. In addition to the tritium and Sr-90 analyses, three September samples, one each from Carey, Idano Falls, and Mud Lake are usually submitted for $1-i 29$ analysis. The 1992 samples were submitted to WINCO for 1-129 analyses using a mass spectrographic method. Analytical results were unavaila' ${ }^{2} e$ for this report but will be reported next year.

In 1992. no milk samples contained detectable concentrations of $1-131$, and none of the ten milk samples submitted for tritium showed a detectable concentration. Six of the ten samples submitted for $\mathrm{Sr}-90$ analyses contained reportable concentrations of this nuclide near the minimum detectable concentration. ranging from $1.1 \pm 0.8 \times 10^{-9}$ to $2.3 \pm 1.4 \times 10^{-9} \mu \mathrm{Ci} / \mathrm{mL}$. The remaining four samples did not have detectable concentrations of $\mathrm{Sr}-90$. Concentrations near the minimum detectable concentration level are difficult to interpret ( $\mathrm{sec}$ Appendix C). However, if it is assumed tha: $\mathrm{Sr}-90$ was present in the samples. the concentrations reported above are similar to or lower than those seen in boundary and distant milk samples from previous years in the INEL vicinity and across the nation as reported in EPA Environmental Radiation Data Reports published each year through $1989 .^{7}$ When the mean $\mathrm{Sr}-90$ concentration from boundary location samples was compared with the mean from distant location samples. no statistically significant difference was seen.

Lettuce-Leltuce samples were washe d with water to remove any soil (as in normal ford preparation) then dried and weighed. All lettlce samples were analyzed for $\Sigma r-90$ and gamma-emitting radionuclides. Cesium -137 was reported in the 1992 Idaho Falls lettucr, sample at $1.3 " 0.6 \mathrm{mCi} / \mathrm{g}$. No other gamma-emutting radionuclides were found. Idaho Falls is a distant, or background, location, and the presence of Cs-137 in the sample is most likely due to particles of resuspended soil that had been contaminated by worldwide fallout in years past. Strontium-90 concentrations reported in most samples were at approximately the same levels as in rast years. Comparison of average concentrations of Sr-90 for boundary and distant communities showed no statistical difference between the two groups. The 1988 through $1992 \mathrm{Sr}-90$ results are shown in Appendix B, Table B-6.

Wheat-Wheat sampics were weighed prior to analysis but not washed. No manmade gamma-emitting radionuclides were detected in any sample. All wheat samples were also analyzed for Sr-90, and results for samples from : 988 through 1992 are shown in Appendix B, Table B-7. Average concentrations of $\mathrm{Sr}-90$ in $"$ heat were statistically the same for boundary and distant samples, and no major differences in concentrations were seell when compared to results of resent years.

Because concentrations of $\mathrm{Sr}-90$ in lettuce and wheat samples were at typical levels and were statistically the same at distant and boundary locations, the origin of this radionuclide is assumed to be deposition of worldwide fallout on the soils of southeastem Idaho during past years.

Sheep-Muscle and liver samples were taken from four sheep that had grazed onsite during 1992: two from the southern grazing area and two from the eastern grazing area (see Figure 10). In addition, iwo sheep from the Blackfoot area, which had never grazed on the INEL, were sampled as controls.

Cs-137 was reportec near the minimum detectable concentration in the muscle tissue of two onsite animals at concentrations of $9 \pm 6 \times 10^{-9} \mu \mathrm{Ci} / g$ and $6 \pm 4 \mu \mathrm{Ci} / g$ and in liver tissues of the same two animals at $3 \pm 2 \times 10^{-9} \mu \mathrm{Ci} / \mathrm{g}$ wet weight. This nuclide was not detected in the tissues of any of the other four sheep sampled, nor were any other nuclides found in any sheep tissue samples for 1992. These concentrations are similar to those seen in onsite. houndary, and control sheep from previous years. 


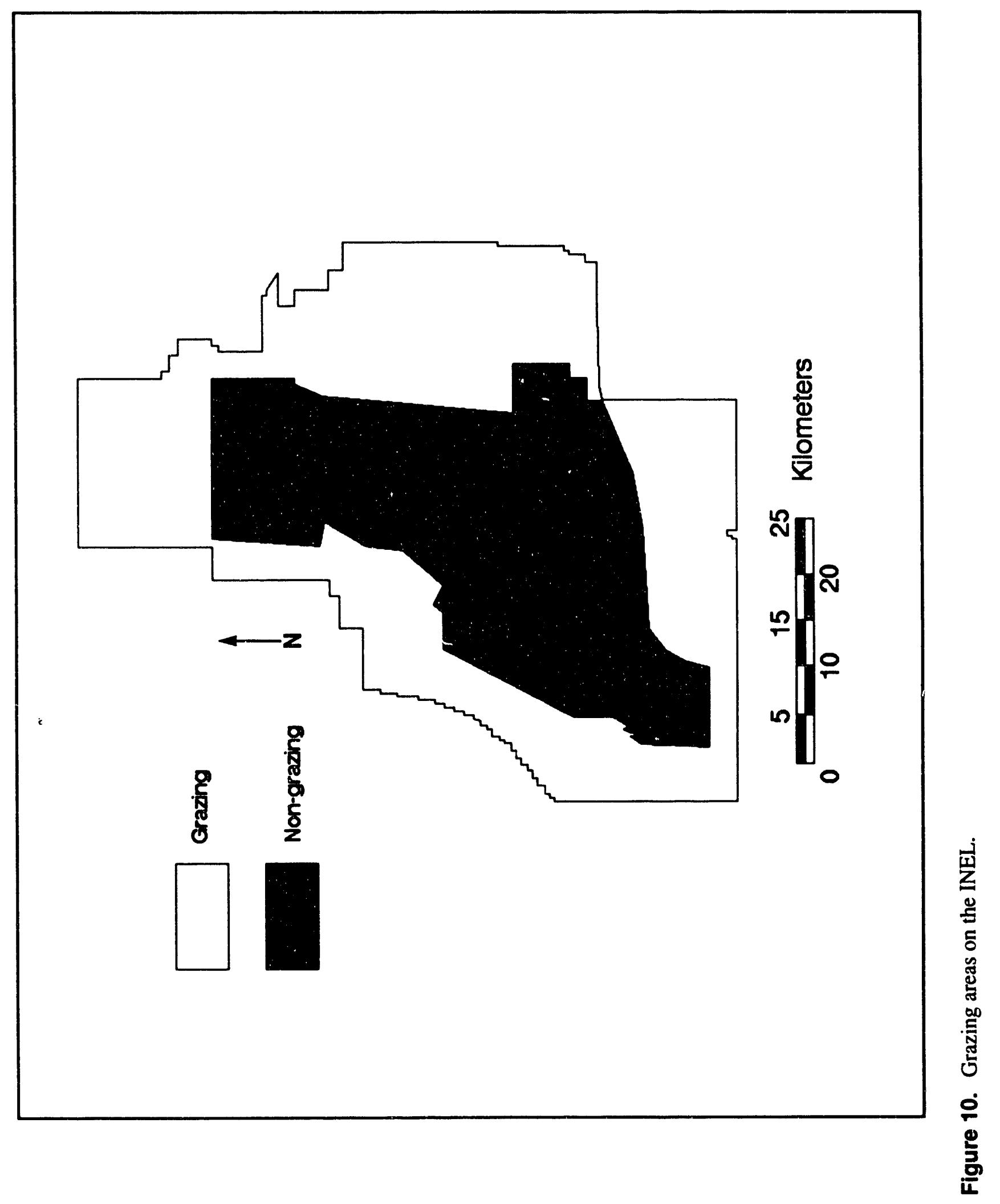


Soil Sampling. To establish background levels of natural and fallout radioactivity in surface : :oil and to assess any potential buildup of radioactivity from Site operations, soil samples were collected annually from distant and boundary locations from 1970-78 (except 1972 and 1977). The biennial soil sampling program was established in 1978, and Figure 11 shows routine offsite sampling locations. A rotating seven-year schedule is used to sample onsite soils around major INEL facilities.

Soil samples collected in 1970, 1971, and 1973 represented a composite of five cores of soil from a $1-\mathrm{m}^{2}$ area. Each core was a cylinder $10 \mathrm{~cm}$ in diameter and $5 \mathrm{~cm}$ in depth. In all other years, the five cores were collected from a $100-\mathrm{m}^{2}$ area. A number of samples from the $5-$ to $10-\mathrm{cm}$ depth were also collected.

Concentrations of natural radioactivity in the surface soil were reported in 1977.8 The U-238 and Th-232 activities were determined from those of the progeny radionuclides, $\mathrm{Pb}-214$ and Ac-228. Oakley ${ }^{9}$ indicated that the average concentrations of uranium, thorium, and $\mathrm{K}-40$ in the earth's upper crust, when translated from parts per million (ppm) to $\mathrm{pCi} / \mathrm{g}$ are $0.9,1.1$, and $17 \mathrm{pCi} / \mathrm{g}$, respectively. The local soils averaged about $1.5,1.3$, and $19 \mathrm{pCi} / \mathrm{g}$, respectively; values that are slightly higher in natural radioactivity than earth crustal averages. Although much of the surface rock on the Snake River Plain is basalt, the local soil is largely derived from silicic volcanics, which have higher uranium and thorium concentrations than basalt (see Reference 8).

Estimates of the average external dose equivalent received from $\mathrm{U}-238$ plus decay products, Th-232 plus decay products, and $\mathrm{K}-40$ in average Site area soil were calculated to be 21,28 , and $27 \mathrm{mrem} / \mathrm{yr}$, respectively, for a total of $76 \mathrm{mrem} / \mathrm{yr}$. Because heavy snow cover can reduce the effective dose equivalent Idaho residents receive from the soil of the area, a correction for the snow cover reduction of the terrestrial dose is made in the following section titled, "Environmental Radiation Measurements."
Currently all soil samples are analyzed for gamma-emitting radionuclides. All offsite surface samples $(0-5 \mathrm{~cm})$ are also analyzed for Sr-90 and alpha-emitting radionuclides. The soils are dried at least three hours at about $120^{\circ} \mathrm{C}$. Only soil particles less than $500 \mu \mathrm{m}$ in diameter (35 mesh) are analyzed. The data are reported in units of activity per gram of soil ( $\mathrm{pCi} / \mathrm{g}$ dry weight) and also in units of areal activity $\left(\mathrm{nCi} / \mathrm{m}^{2}\right)$, which is the total activity in each soil sample divided by the surface area $\left(0.039 \mathrm{~m}^{2}\right)$ of the sample.

Surface soil concentrations of Cs-137, Sr-90, $\mathrm{Pu}-238, \mathrm{Pu}-239 / 240$, and Am-241, as measured from 1970-75, are compared to biennial samples since 1978 in Appendix B, Table B-8. The 1976 data are not included because the sampling locations used that year are not considered to be representative of the area. Three samples from 1984-Mud Lake No. 1, Mud Lake No. 2, and Crystal Ice Caves-were excluded from 1984 data because the concentrations were uncharacteristically low compared to previous years. This may have been caused by disturbance (farming, erosion, vehicular traffic, etc.) of the sampling locations. These sampling locations, plus the location at Monteview were re-evaluated and moved to more representative undisturbed locations in 1986. The $1992 \mathrm{Sr}-90$ results were not available in time for this report and will be published in 1993.

The 1992 boundary group average concentrations were not statistically greater than the distant group concentrations for any radionuclide. It is concluded, therefore, that all of the radionuclides detected are present as a result of worldwide fallout.

\section{Environmental Radiation Measurements.}

Thermoluminescent dosimeters (TLDs) are used to measure ionizing radiation exposures (beta greater than $200 \mathrm{keV}$ and gamma greater than $10 \mathrm{keV}$ ). The TLDs measure ionizing radiation exposures from natural radioactivity in the air and soil, cosmic radiation from outer space, fallout from nuclear weapons tests, radioactivity from fossil fuel burning, and radioactive effluents from Site operations and other industrial processes. 

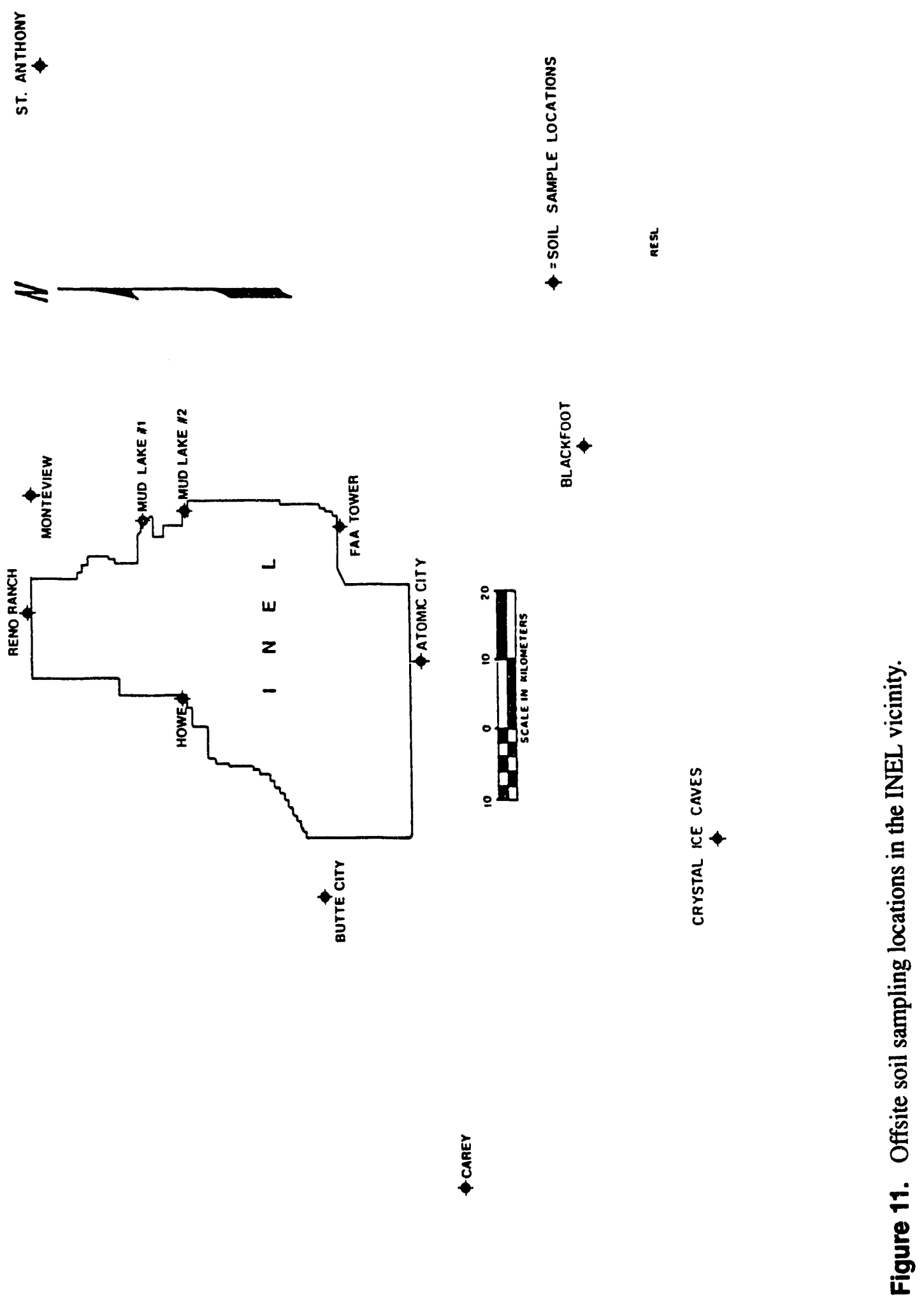
At each location, a dosimeter card containing five individual Harshaw TLD-700 chips $(3.18 \times 3.18 \times 0.89 \mathrm{~mm})$ is placed $1 \mathrm{~m}$ above ground level. The dosimeter card at each location is changed semiannually. There are seven distant community locations and six boundary locations (see Figure 7). The measured cumulative exposure for the time period from November 1991 to November 1992 for offsite locations is shown in Appendix B, Table B-9. For purposes of comparison, annual exposures from 1988-91 are also included for each location. The TLD doses for 1991 and 1992 are about 10 to 15 mrem higher than in previous years. The Radiological Sciences Branch (RSB) at RESL is performing an investigation to determine possible causes for the increase in reported doses.

The mean annual exposures for distant and boundary community locations in 1992 were $128 \pm 11 \mathrm{mR}$ and $127 \pm 10 \mathrm{mR}$, respectively, as measured by TLDs. The average exposures of the offsite groups are approximately equivalent to 132 and $131 \mathrm{mrem}$, respectively, when a dose equivalent conversion factor of $1.03^{10}$ is used to convert from $\mathrm{mR}$ to mrem in tissue.

Table IV summarizes the calculated effective dose equivalent an individual receives on the Snake River Plain from various background radiation sources. The terrestrial portion of this value, which is based on soil sampling for natural radionuclides in 1976, varies from year to year depending on the amount of snow cover. ${ }^{11}$ For 1992 , the snow cover resulted in about a $1 \%$ dose reduction, and the terrestrial background dose equivalent was calculated to be about $75 \mathrm{mrem}$.

The cosmic component varies primarily with altitude. The average annual dose equivalent of 26 mrem at sea level essentially doubles with each $2000 \mathrm{~m}(6560 \mathrm{ft})$ increase in altitude. ${ }^{12}$ The INEL Site altitude is approximately $1500 \mathrm{~m}$ $(4900 \mathrm{ft})$. The sum of the estimated terrestrial and cosmic components for 1992 is 113 mrem, which is lower than the 132 mrem measured by TLDs at distant locations. As discussed earlier, an investigation is underway to determine why the difference between the estimated and measured doses has increased over the past two years. ESTIMATED NATURAL BACKGROUND EFFECTIVE DOSE EQUIVALENT (1992)

\begin{tabular}{|c|c|c|c|}
\hline \multirow{2}{*}{\multicolumn{2}{|c|}{$\begin{array}{l}\text { Source of } \\
\text { Radiation Dose } \\
\text { Equivalent }\end{array}$}} & \multicolumn{2}{|c|}{$\begin{array}{l}\text { Total Average Annual } \\
\text { Effective Dose } \\
\text { Equivalent (mrem) }\end{array}$} \\
\hline & & Estimated ${ }^{a}$ & $\begin{array}{l}\text { Measured } \\
(T L D)^{b}\end{array}$ \\
\hline \multicolumn{4}{|c|}{ External: } \\
\hline & Terrestrial & 74 & - \\
\hline \multicolumn{2}{|r|}{ Cosmic } & 39 & - \\
\hline & Subtotal & 113 & 132 \\
\hline \multicolumn{4}{|c|}{ Internal } \\
\hline & Cosmogenic $\mathrm{c}$ & 1 & \\
\hline & Inhaled nuclides & 200 & \\
\hline & $\mathrm{K}-40$ and others & 39 & \\
\hline & Subtotal & 240 & \\
\hline & Total & 353 & \\
\hline a. & \multicolumn{3}{|c|}{$\begin{array}{l}\text { Total average annual effective dose equivalents for com- } \\
\text { ponents as estimated in NCRP Report No. } 93.12\end{array}$} \\
\hline b. & \multicolumn{3}{|c|}{$\begin{array}{l}\text { For conversion from } \mathrm{mR} \text { in air to mrem in tissue, the dose } \\
\text { equivalent conversion factor used was } 1.03 \text {. }\end{array}$} \\
\hline c. & \multicolumn{3}{|c|}{$\begin{array}{l}\text { The cosmogenic component is due primarily to } \mathrm{C}-14 \text { in tis- } \\
\text { sues and is uniform globally. }{ }^{12}\end{array}$} \\
\hline d. & \multicolumn{3}{|c|}{$\begin{array}{l}\text { The inhaled radionuclides component varies widely with } \\
\text { geographic location. The } 200 \text { mrem shown represents the } \\
\text { U.S. population average. }{ }^{11}\end{array}$} \\
\hline
\end{tabular}

The component of natural background dose that varies the most is that of inhaled radionuclides. According to the National Council on Radiation Protection (NCRP) the major radionuclides contributing to this component are shortlived decay products of radon, and the amount of radon in buildings and ground water depends upon the natural radionuclide content of the soil and rock of the area. ${ }^{11}$ There is also variation between buildings of a given geographic area depending upon the materials each contains, the 
amount of ventilation and air movement, and other factors. The U.S. average of 200 mrem has been used in Table IV for this component of the total background dose because no specific estimate for southeastern Idaho has been made, and measurements in homes in this area are few. Therefore, the effective dose equivalent from natural background radiation for residents in the INEL vicinity may actually be higher or lower than the total estimated natural background dose of about 350 mrem shown in Table IV and will vary from one location to another.

Game Species. Hunting and fishing are not usually allowed on the INEL Site. However, beginning in 1989, an exception was made by permitting hunter access to one-half mile within the northern INEL boundaries facilitating access to the adjacent farm lands. This portion of the INEL was part of an offsite hunting unit for pronghorn and elk in 1989 and for pronghorn only in 1990, 1991, and 1992. The hunts, scheduled in response to farmers' claims of significant big game animal depredation, were negotiated between the Idaho Department of Fish and Game and DOE-ID. Just prior to the first pronghorn hunt, RESL collected antelope from farms adjacent to the INEL and submitted tissue samples for radionuclide analysis. No manmade radionuclides were detected in the edible tissues of any of the animals.

By migrating to and from the Site, game animals represent a potential, but not very likely, exposure pathway. The probability that an individual in the population would consume an animal containing detectable amounts of radioactivity is small because most animals that migrate from the INEL do not contain elevated levels of contaminants. While onsite, some game animals may use the waste infiltration ponds at TRA and ICPP for water. Although the ponds are fenced to exclude antelope, the TRA fence may not exclude all deer. Neither, of course, do the fences exclude game birds, which have used the ponds in the past for resting and feeding sites. Larger game animals may also ingest vegetation and soil that has been contaminated by Site operations. However, these particular animals are not likely to be harvested before the radionuclides have been eliminated from their bodies.

Data from game species may be obtained as part of DOE research programs rather than as part of the routine environmental surveillance program. Generally, only data from road-killed animals are summarized in this report. Results from the radioecology and ecology research programs, which use the expertise of university faculty and graduate students, are reported in the scientific literature and supplement the results of the routinely scheduled environmental surveillance included in this report. Results from some of the radioecology studies that investigated potential doses to man from game animals migrating from the Site are discussed in the section entitled "Maximum Individual Dose-Game Ingestion Pathway." In December 1991, a complete bibliography of the INEL Radioecology and Ecology Program research studies was published. ${ }^{13}$

Muscle and liver samples from one mule deer, one elk, and four pronghorn, all killed by vehicles on Site roads in 1992, were submitted for analysis by gamma spectrometry.

Of the four pronghorns sampled, two had reported concentrations of Cs-137 near the minimum detectable concentration in muscle, but no radionuclides were detected in liver tissue samples. The mule deer muscle tissue sample showed a low concentration of Cs-137. Neither muscle nor liver tissue sample from the elk contained detectable concentrations of any gamma-emitting radionuclides. Appendix B, Table B-10, shows the concentrations reported from these six animals. 
While it is known that the soil around some facilities is contaminated with $\mathrm{Cs}-137$, this nuclide was also a constituent of worldwide fallout during atmospheric weapons testing and has been found in the soil at locations distant from the Site. As a result, game animals sampled from offsite distant areas (control animals) occasionally contain Cs-137 in their muscle and liver tissues. The 1980 monitoring report gave the average concentrations of Cs-137 found in tissues of control animals sampled in studies of earlier years as $3.8 \times 10^{-8} \mu \mathrm{Ci} / \mathrm{g}$ for muscle and $4.7 \times 10^{-8} \mu \mathrm{Ci} / \mathrm{g}$ for liver tissues. The reported Cs-137 concentrations in 1992 animals sampled were all lower than those levels in control animals.

No fish were collected from the portion of the Big Lost River within the INEL boundaries during 1992 because it was dry the entire year.

\section{Summary of Radioactive Effluent Monitoring}

Radionuclides in airborne and liquid effluents released to the environment are carefully monitored at potentially significant release points. Effluent monitoring at the INEL is described in the Baseline Document of the INEL Environmental Monitoring Plan. ${ }^{14}$ INEL contractors monitor stacks and liquid effluent streams as required by state and Federal regulators, and data are reported to the RWMIS, which publishes quarterly reports of the results of the effluent monitoring by month, facility, and radionuclide.

A summary of the radionuclides released to the atmosphere from Site facilities in 1992 is shown in Appendix B, Table B-11. Because of radioactive decay of the short-lived radionuclides and the overestimation of $\mathrm{Kr}-85$ releases for classification reasons, the activity that would reach offsite areas is less than the $24,000\left(9 \times 10^{14} \mathrm{~Bq}\right)$ indicated in Table B-11. The ICPP and TRA facilities were the source of about $98 \%$ of the total radioactivity released to the atmosphere. Noble gases comprised more than $99 \%$ of the total airborne radioactive effluent.
Air emissions from nonpoint, or diffuse, sources such as radioactive waste ponds (TRA and ICPP) and known contaminated soil areas on the INEL were evaluated in 1992. The total of the doses from all such sources for 1992 was $9 \times 10^{-5}$ mrem $\left(9 \times 10^{-7} \mathrm{mSv}\right) .^{\mathrm{d}}$

The total annual airborne radioactive effluent varies from year to year, depending on which processes are active at INEL facilities. The overestimation of $\mathrm{Kr}-85$ releases for classification reasons masks trends, if any, in other airborne effluents.

No liquids were released directly to the offsite environment. Onsite releases are summarized in Appendix B, Table B-12. Most liquid radioactive effluents are discharged into seepage ponds. The effluent listed for CFA is discharged through a sewage treatment facility. Site-related radioactive liquids have not been detected outside the INEL boundaries, with the possible exceptions of $\mathrm{Cl}-36$ and $\mathrm{I}-129$. These nuclides have been detected in samples from USGS observation wells south of the INEL in minute concentrations using sophisticated analytical techniques. Neither radionuclide has been found in offsite drinking water wells, and the concentrations of each in offsite observation well was about 100,000 times less than the regulatory standards.

\section{Assessment of Potential Radiation Dose to the Public}

General Information. Usually, the radiological impact of INEL operations on the resident public surrounding the Site has been too small to be measured by the routine monitoring program. Therefore, the radiological impact of INEL operations by the air pathway has traditionally been estimated using the known amounts of various radionuclides released during the year from Site facilities and appropriate air dispersion models, described in the next section, to determine the concentrations at selected locations in the vicinity. During 1992, this was done for the radionuclides released from Site facilities to the

d. Prepublication results from Richard Moore, DOE-ID/RESL, June 1993. 
atmosphere as summarized in Appendix B, Table B-11.

For the reasons discussed below, RESL uses two different air dispersion models to calculate the:

- Effective dose equivalent to the maximally exposed individual residing offsite using the EPA-required CAP- 88 model

- Effective dose equivalent to the maximally exposed individual residing offsite using the MESODIF dispersion model ${ }^{15}$

- Collective effective dose equivalent (population dose) within an $80-\mathrm{km}(50-\mathrm{mi})$ radius of the operations center of the Site (TRA and ICPP) using the MESODIF dispersion model.

For simplicity, the term dose will mean effective dose equivalent in the following dose assessment sections, unless another term is specifically stated. The effective dose equivalent was calculated by summing the committed dose equivalents to organs, each multiplied by a weighting factor that is proportional to the organ's radiosensitivity. The effective dose equivalent includes doses received from both external and internal sources and represents the same risk as if an individual's whole body were irradiated uniformly. DOE dose conversion factors and a 50-yr integration period are used for internally deposited radionuclides and for radionuclides deposited on ground surfaces in calculations with both air dispersion models. Because the hypothetical effective dose equivalent to the maximally exposed individual residing near the INEL is so low, no allowance was made for shielding by housing materials or residence time in the community in any of the calculations using the MESODIF dispersion model. The CAP- 88 code, which is used by all sites regardless of the magnitucie of the hypothetical dose, does include a factor to allow for shielding and occupancy time.

The possible exposure pathways by which radioactive materials from Site operations could be transported to offsite environs are shown diagrammatically in Figure 12. No surface streams flow from within the INEL to offsite locations. Low, but detectable, concentrations of tritium, the most mobile low-level radioactive waste in the water of the aquifer, were reported in samples from wells just inside the Site boundary in 1983. However, tritium from the INEL has never been detected in any of the drinking water wells south of the boundary; and the $0.5 \mathrm{pCi} / \mathrm{L}$ contour on plume maps had receded northward by 1988 as seen in Figure 8 presented earlier. Thus, atmospheric transport is the principal potential exposure pathway from the Site and is described in the section "Maximum Individual Dose-Airborne Emissions Pathway Only."

Several indirect exposure pathways are being studied at the INEL to determine their effect, if any, on the highest possible dose that could have been received by a member of the public. The principal indirect exposure pathway involves eating animals of game species that have spent time on the Site. Radioactivity present in game species depends upon the length of residence at each onsite location, the time elapsed since migration from the Site, and the metabolism of the animal. Estimates of the maximum potential dose to a person consuming meat from different game animals is described in the section "Maximum Individual Dose-Game Ingestion Pathway." 


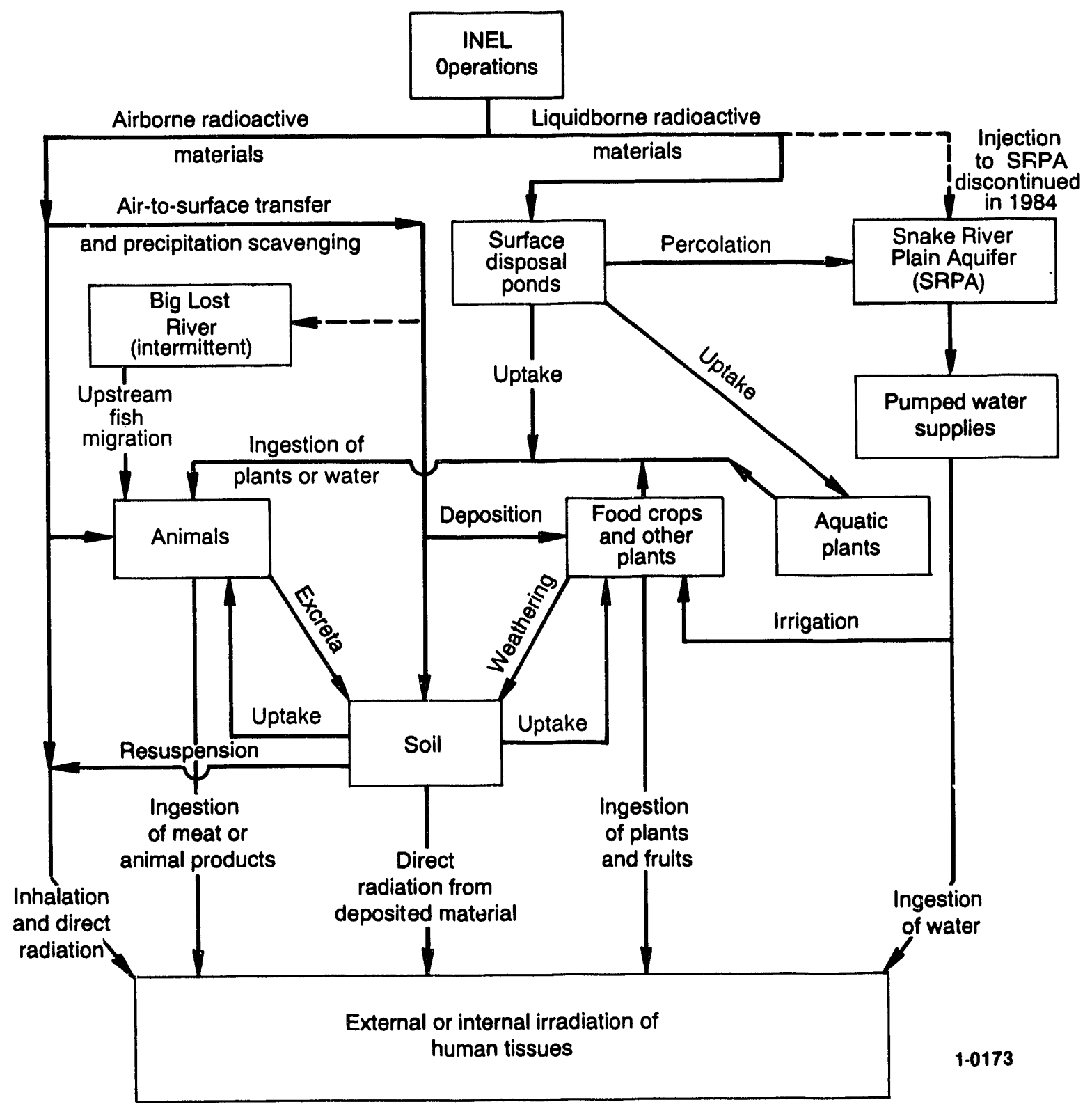

Figure 12. Detailed diagram of possible exposure pathways of the INEL Site radioactive materials to members of the public. 
Maximum Individual Dose-Airborne Emissions Pathway Only. During 1992, EPA regulations (40 CFR 61) were in effect that limited the amount of airborne radionuclides released from any nuclear facility to that which will produce an effective dose equivalent of $10 \mathrm{mrem} / \mathrm{yr}$ to any member of the public. The EPA has specified that the CAP- 88 computer code be used to demonstrate compliance unless an alternate model has been approved by the Administrator of the EPA.

Using the CAP- 88 code and selected INEL facility emissions, a 1992 hypothetical effective dose equivalent of $0.0009 \mathrm{mrem}\left(9 \times 10^{-6} \mathrm{mSv}\right)$ was calculated for a member of the public at Atomic City, Idaho, $19 \mathrm{~km}(12 \mathrm{mi})$ southeast of the operations center of the INEL Site. This dose is $0.009 \%$ of the EPA radiation protection standard. The facilities selected included TRA, ICPP, PBF, WERF, Auxiliary Reactor Area (ARA), CFA, and RWMC because a resident of Atomic City would be the maximally exposed individual for all these facilities. Furthermore, the 1992 emissions from these facilities comprised about 98\% of the total INEL emissions. The 1992 effective dose equivalent for the maximally exposed individual at Atomic City, according to the CAP-88 code, was primarily due to $\mathrm{Ar}-41$ and $\mathrm{Kr}-88$.

This CAP-88 dose for an Atomic City resident uses a somewhat different approach from that used for demonstrating compliance in the annual NESHAP's report which is submitted to EPA. Because the INEL operations are spread over a wide area, the potential offsite doses occur at a variety of receptor (nearest resident) locations. For the NESHAPs report, the offsite dose was calculated for the nearest resident to each INEL facility that reported airborne releases in 1992 , then the doses from all facilities were summed. The total dose of $0.0018 \mathrm{mrem}\left(1.8 \times 10^{-5} \mathrm{mSv}\right)$ assumes that an individual resides at all offsite receptor locations simultaneously. This is considered a conservative, or maximizing, approach rather than a realistic one. A thorough discussion of the NESHAPs calculations will appear in the 1992 INEL NESHAPs annual report to be submitted to EPA by June 30,1993 . The CAP- 88 dose for an Atomic City resident is more comparable to the dose calculated with the MESODIF model discussed next.

The MESODIF air dispersion model has been used for 20 years to calculate doses to members of the public residing near the INEL. The MESODIF diffusion curves, developed from tests at the INEL and Hanford desert environments, appear to be more appropriate for the INEL Site than the EPA-required model. MESODIF uses a more complicated puff Gaussian plume model than the straight-line Gaussian plume model in CAP-88. Although the doses calculated with the MESODIF model are usually somewhat higher than doses using CAP-88, the doses and offsite concentrations calculated using both models were compared to actual monitoring results at offsite locations in 1986, 1987, and 1988. Concentrations and doses calculated using the MESODIF model showed good agreement with those from actual measurements at several locations. A more detailed discussion of differences between the two air dispersion models was given in the 1986 annual report. ${ }^{16}$ Therefore, the effective dose equivalent calculated using the MESODIF model is included in this report, as well as the value calculated using the EPA-required CAP-88 model.

The mesoscale meteorological map (Figure 13) shows the calculated 1992 concentrations normalized to a unit release rate for the INEL Site and vicinity. This map has been prepared by the National Oceanic and Atmospheric Administration (NOAA) at the INEL using the MESODIF model and data gathered continuously at meteorological stations on and around the Site. To facilitate the display, the dispersion coefficient values are given in whole numbers and must be multiplied by $10^{-9} \mathrm{~h}^{2} / \mathrm{m}^{3}$. To obtain the average air concentration $\left(\mathrm{Ci} / \mathrm{m}^{3}\right)$ for a radionuclide released from TRA or ICPP along any dispersion coefficient isopleth in Figure 12, the value of the 1992 average dispersion coefficient (for example, $30 \times 10^{-9} \mathrm{~h}^{2} / \mathrm{m}^{3}$ ) was multiplied by the number of curies of the radionuclide released during 1992 and divided by the number of hours in a year squared $\left(7.67 \times 10^{7}\right)$. 


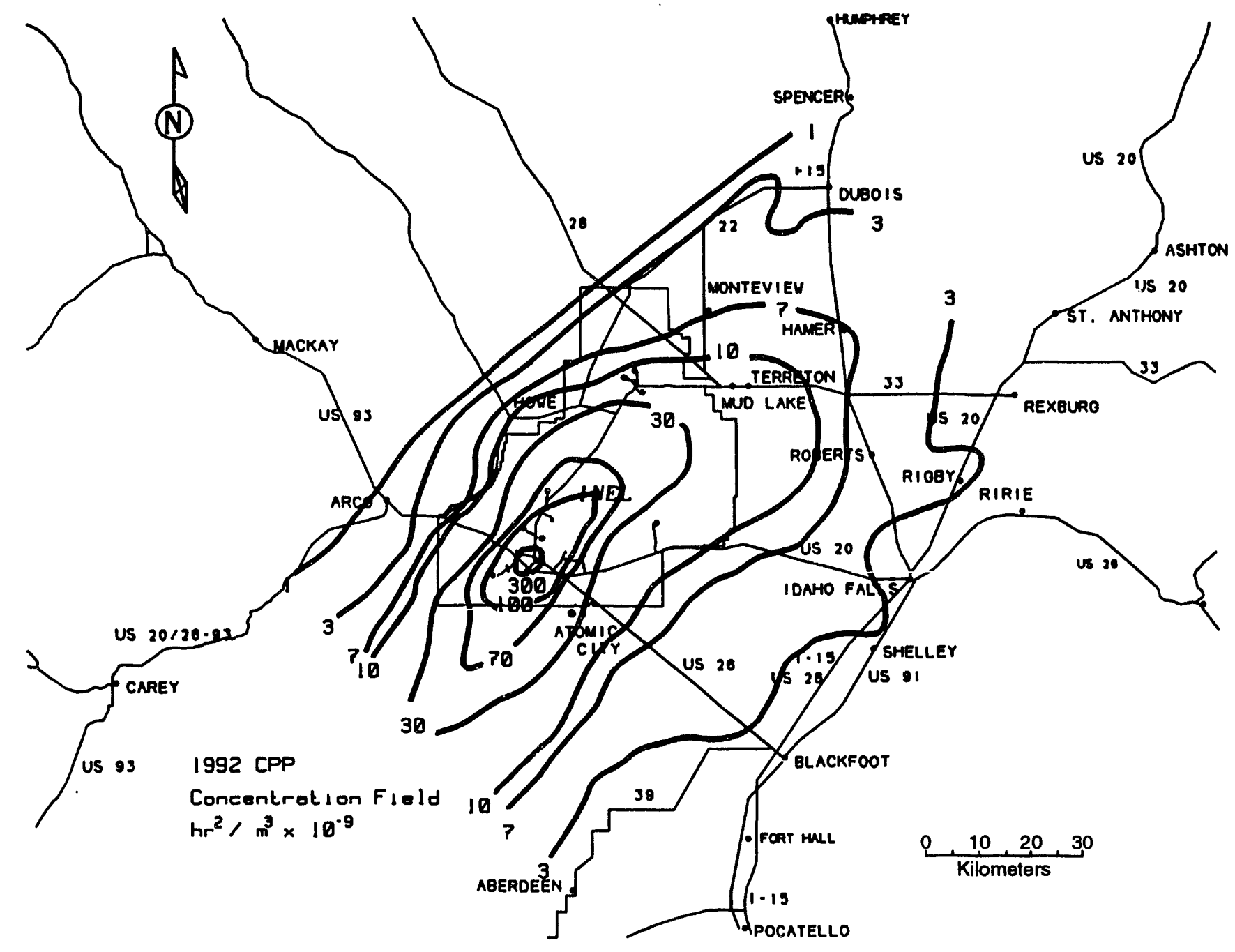

Figure 13. 1992 average of mesoscale dispersion isopleths of air concentrations at ground level, normalized to unit release rate. 
As indicated in Figure 13, the MESODIF model predicts that the highest concentrations of radionuclides in air for an inhabited area would occur at Atomic City, Idaho. The maximum hypothetical dose was calculated for an adult resident of that location from inhalation of air, submersion in air, ingestion of radioactivity on leafy vegetables, and exposure due to deposition of particulates on the ground surface. The calculation was based on data presented in Appendix B, Table $B-11$, and Figure 13. Using $53 \times 10^{-9} \mathrm{~h}^{2} / \mathrm{m}^{3}$ as the dispersion coefficient for Atomic City and allowing for radioactive decay during the 19-km (12- $\mathrm{mi})$ transit of the radionuclides from the TRA/ICPP facilities to the Atomic City location, the potential effective dose equivalent from all radionuclides released was calculated to be $0.004 \mathrm{mrem}\left(4 \times 10^{-5} \mathrm{mSv}\right.$ ) (see Table $\mathrm{V}$ ). This dose is $0.004 \%$ of the DOE radiation protection standard for a prolonged period of exposure to a member of the public from all pathways and $0.04 \%$ of the EPA standard for the airborne pathway only. Figure 14 illustrates the proportion of specific nuclides comprising the maximum individual dose for 1992 . For comparison, Appendix B, Figure B-2 shows the proportions of individual radionuclides contributing to the maximally exposed individual effective dose equivalents for 1988 through 1991.

One of the parameters necessary to convert air concentrations into dose equivalents is the deposition velocity - the rate at which the particulates are deposited on the surface of the ground. For the calculations based on the MESODIF model, a deposition velocity for particulates of $0.18 \mathrm{~cm} / \mathrm{s}$ was used, which is consistent with other INEL dose assessments. A deposition velocity for elemental iodines of $1.8 \mathrm{~cm} / \mathrm{s}$ was used. Organic iodides, which make up two-thirds of the ICPP I-129 releases during more typical processing years, have a much lower deposition velocity to ground surfaces $(0.018 \mathrm{~cm} / \mathrm{s})$.

\section{MAXIMUM INDIVIDUAL EFFECTIVE DOSE EQUIVALENT (1992)}

\begin{tabular}{|c|c|c|c|}
\hline \multirow[b]{2}{*}{ Radionuclide ${ }^{a}$} & \multirow{2}{*}{$\begin{array}{l}\text { Maximum Offsite } \\
\text { Concentrationb } \\
(\mu \mathrm{Ci} / \mathrm{mL})\end{array}$} & \multicolumn{2}{|c|}{ Maximum Effective Dose Equivalent } \\
\hline & & (mrem) & $(\mathrm{mSv})$ \\
\hline $\mathrm{Ar}-41$ & $4.7 \times 10^{-13}$ & 0.0031 & $3 \times 10^{-5}$ \\
\hline$K r-88+D$ & $3.7 \times 10^{-14}$ & 0.00060 & $6 \times 10^{-6}$ \\
\hline $\mathrm{Xe}-138+\mathrm{D}$ & $8.1 \times 10^{-16}$ & 0.00015 & $2 \times 10^{-6}$ \\
\hline$x e-135$ & $8.5 \times 10^{-14}$ & 0.00011 & $1 \times 10^{-6}$ \\
\hline $\mathrm{Kr}-87$ & $2.0 \times 10^{-14}$ & ¿.000089 & $9 \times 10^{-7}$ \\
\hline $\mathrm{Kr}-85$ & $3.6 \times 10^{-12}$ & 0.000080 & $8 \times 10^{-7}$ \\
\hline$C s-137+D$ & $7.5 \times 10^{-19}$ & 0.000037 & $4 \times 10^{-7}$ \\
\hline $\mathrm{Sr}-90+\mathrm{D}$ & $8.7 \times 10^{-20}$ & 0.000032 & $3 \times 10^{-7}$ \\
\hline$x e-133$ & $9.6 \times 10^{-14}$ & 0.000017 & $2 \times 10^{-7}$ \\
\hline$K r-85 m$ & $1.8 \times 10^{-14}$ & 0.000015 & $2 \times 10^{-7}$ \\
\hline Rounde & & 0.004 & $4 \times 10^{-5}$ \\
\hline
\end{tabular}

a. Table includes only radionuclides which contribute a dose of $0.00001 \mathrm{mrem}\left(1 \times 10^{-7} \mathrm{mSv}\right)$ or more. When indicated ( $\left.+\mathrm{D}\right)$, the contribution of daughter decay products was included in the dose calculations.

b. Estimate of radioactive decay obtained by using the 1992 average windspeed from $315^{\circ}-325^{\circ}$ of $11.2 \mathrm{~km} / \mathrm{h}$ and a distance of $19.1 \mathrm{~km}$ from TRA-ICPP to the Atomic City area, the location where the hypothetical maximally exposed individual would have resided. For nuclides where parent-daughter equilibria were used in dose calculations, concentration of the parent is shown.

c. Effective dose equivalent estimated using doseconversion factors for inhalation and ingestion from Reference 39 and dose conversion factors for submersion and deposition from Reference 40. 


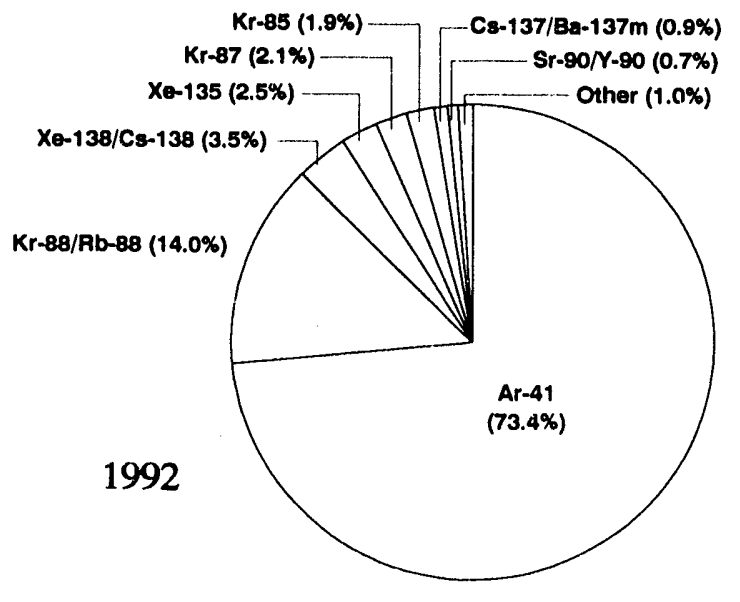

Figure 14. Nuclides contributing to maximum individual dose in 1992.

As discussed earlier, there are differences in the atmospheric dispersion portions of the MESODIF and CAP-88 air dispersion codes, and RESL has chosen to use the MESODIF doses for comparison to most standards and to calculated doses from previous years. The calculated dose of $0.004 \mathrm{mrem}\left(4 \times 10^{-5} \mathrm{mSv}\right)$ resulting from INEL operations is very small compared to the measured 132 mrem average dose individuals in southeastern Idaho received from cosmic and terrestrial radiation during 1992 . The calculated dose is even smaller compared to the total estimated effective dose equivalent from natural background radiation of about $350 \mathrm{mrem}$ (see Table IV). For perspective, the calculated dose may also be compared to the approximately 30-mrem average dose received from medical diagnostic procedures, the 4-mrem average dose received from highway and road construction materials, and the 0.04 to 0.1 mrem received from luıninous watches and clocks. ${ }^{12}$ Another source has estimated that the average five-hour jet flight contributes a dose of about 0.7 mrem to passengers, and that the average television viewer receives about 0.05 to 0.1 mrem annually. ${ }^{17}$
Maximum Individual Dose-Game Ingestion Pathway. Potential dose to an individual from occasional ingestion of meat from game animals continues to be investigated. One group of studies involves the calculation of potential doses to individuals who might eat ducks that reside briefly upon liquid waste ponds used for the disposal of low-level reactor effluents.

In one study, wing-clipped mallards were released on the TRA pond for 56-188 days before collection. Various tissues were analyzed for concentrations of $\mathrm{Sr}-90, \mathrm{Pu}-238, \mathrm{Pu}-239 / 240$, Am-241, Cm-242, and Cm-244. The potential effective dose equivalent to a human consuming the entire muscle and liver mass of one experimental duck with average nuclide concentrations was 0.046 mrem from those specific nuclides. ${ }^{18}$ In the most recent study, ${ }^{\mathrm{e}}$ migratory waterfowl were collected from several ponds onsite ranging from the sewage disposal pond at Naval Reactors Facility (NRF), where no radioactive contamination was expected, to the radioactive waste pond at TRA. Several tissues from these birds were analyzed for gamma-emitting radionuclides. The predicted committed effective dose equivalent to an individual eating the entire muscle and liver mass of the most contaminated duck (collected from the TRA radioactive waste pond) was $4.0 \mathrm{mrem}(0.040 \mathrm{mSv})$. The median committed effective dose equivalent, based on TRA ducks was $0.4 \mathrm{mrem}\left(4 \times 10^{-3} \mathrm{mSv}\right)$ and all waterfowl in the study, was 0.002 mrem $\left(2.7 \times 10^{-5} \mathrm{mSv}\right)$. In an earlier study, wild ducks were collected from the TRA radioactive waste ponds and the potential doses to a person consuming the ducks were calculated before and after cooking. The average potential whole body dose equivalent from gamma-emitting radionuclides was lower after cooking. 19

During a previous study, it was determined that Idaho hunters harvest about 25,000 ducks per year, of which about six have spent time on INEL ponds. ${ }^{20}$ More recent estimates (based on 1984-85 data) indicate that about 4 ducks that have spent time on the TRA radioactive waste

e. Unpublished data from Randall C. Morris, DOE-ID, April 1993. 
pond are harvested by Idaho hunters each year. ${ }^{21}$ In recent years, the volume and surface area of TRA radioactive waste ponds have decreased markedly, and since other less--contaminated ponds have been constructed nearby, the number of ducks visiting the radioactive waste ponds has most likely decreased since 1984-85 time period. The doses calculated above are based on the unlikely assumption that the duck would be killed and eaten immediately after leaving the pond, so a lower dose would be more realistic due to biological elimination of the radioactivity. For example, the largest contributor to the dose, Cs-137, has an effective half-life in ducks of 11.2 days. ${ }^{22}$ This means that half of the C $\$-137$ present when a given duck leaves the pond would be eliminated in 11.2 days. At the end of the next 11.2 days, half of the remaining radioactivity (or one-fourth of the original activity) would be eliminated, and so on until the amount of $\mathrm{Cs}-137$ present in the duck's tissues can no longer be detected.

The highest estimated potential whole-body dose equivalent to a person eating the entire muscle mass of a sage grouse that summered near the TRA-ICPP area is 2 mrem. ${ }^{23}$ The maximum whole-body dose equivalent from consumption of sage grouse from other onsite locations and offsite areas ranges from 0.01 to $0.04 \mathrm{mrem}$.

The maximum potential whole-body dose equivalent to a person eating the muscle tissue of one mourning dove from the TRA pond area is $0.3 \mathrm{mrem}$. The average whole-body dose equiva- lent to people consuming doves migrating from onsite to offsite areas is $0.01 \mathrm{mrem}$, which is the same as for control birds collected far from the INEL. ${ }^{24}$

A conservative (or high) estimate of the potential whole-body dose equivalent which could be received by a single individual eating the entire muscle and liver mass of an antelope (collected on the INEL after August 1975) with the highest levels of radionuclides is 0.2 mrem. $^{25}$

80-Kilometer Population Dose. An estimate was made of the collective effective dose equivalent (population dose) from inhalation, submersion, ingestion, and deposition that could have been received by all members of the public within an $80-\mathrm{km}(50-\mathrm{mi})$ radius of the TRA/ICPP facilities. This population dose (person-rem) is calculated by a computer program that multiplies the population number in each square mile ${ }^{26}$ by the dispersion coefficient at that point $\left(\mathrm{h}^{2} / \mathrm{m}^{3}\right)$ and the normalized dose received at the location of the maximally exposed individual (rem per year $/ \mathrm{h}^{2}$ per $\mathrm{m}^{3}$ ). The calculation overestimates dose, however, because radioactive decay of the isotopes was not calculated during transport over distances greater than the $19 \mathrm{~km}(12 \mathrm{mi})$ from the TRA/ICPP facilities to the Atomic City maximum location. Idaho Falls, for example, is about $66 \mathrm{~km}(41 \mathrm{mi})$ from TRA/ICPP. Neither residence time nor shielding by housing was considered when calculating the MESODIF dose on which the collective dose is based. 
TABLE VI

80-KILOMETER POPULATION DOSE (1992)

\begin{tabular}{|c|c|c|c|}
\hline \multirow[b]{2}{*}{ Census Division } & \multirow{2}{*}{$\begin{array}{c}\text { Population a } \\
1990\end{array}$} & \multicolumn{2}{|c|}{ Population Dose ${ }^{b}$} \\
\hline & & (person-rem) & (person-sv) \\
\hline Aberdeen & 2,760 & 0.00085 & $8.5 \times 10^{-6}$ \\
\hline Alridge (part) & 160 & 0.000019 & $1.9 \times 10^{-7}$ \\
\hline American Falls (part) & 200 & 0.000094 & $9.4 \times 10^{-7}$ \\
\hline Arco & 2.500 & 0.00071 & $7.1 \times 10^{-6}$ \\
\hline Atomic City (city) & 25 & 0.000068 & $6.8 \times 10^{-7}$ \\
\hline Atomic City (division) & 2,300 & 0.00013 & $1.3 \times 10^{-6}$ \\
\hline Blackfoot & $1<, 450$ & 0.0030 & $3.0 \times 10^{-5}$ \\
\hline Carey (part) & 120 & 0.0000084 & $8.4 \times 10^{-8}$ \\
\hline Challis (part) & 10 & 0.00000023 & $2.3 \times 10^{-9}$ \\
\hline Firth & 3,050 & 0.00077 & $7.7 \times 10^{-6}$ \\
\hline Fort Hall (part) & 3,930 & 0.00026 & $2.6 \times 10^{-6}$ \\
\hline Hamer & 2,400 & 0.0032 & $3.2 \times 10^{-5}$ \\
\hline Howe & 325 & 0.00042 & $4.2 \times 10^{-6}$ \\
\hline Idaho Falls & 63,500 & 0.015 & $1.5 \times 10^{-4}$ \\
\hline Idaho Falls West & 1,750 & $0 . j 0018$ & $1.8 \times 10^{-6}$ \\
\hline Leadore (part) & 15 & 0.0000047 & $4.7 \times 10^{-8}$ \\
\hline Lewisville-Menan (part) & 2,700 & 0.0011 & $1.1 \times 10^{-5}$ \\
\hline Mackay & 1,200 & 0.000029 & $2.9 \times 10^{-7}$ \\
\hline Moreland & 8,150 & 0.00028 & $2.8 \times 10^{-6}$ \\
\hline Rigby (part) & 1,000 & 0.00023 & $2.3 \times 10^{-6}$ \\
\hline Roberts & 1,430 & 0.0012 & $1.2 \times 10^{-5}$ \\
\hline Shielley & 6,400 & 0.0027 & $2.7 \times 10^{-5}$ \\
\hline Ucon & 4,900 & 0.0011 & $1.1 \times 10^{-5}$ \\
\hline West Clark (part) & 90 & 0.00013 & $1.3 \times 10^{-6}$ \\
\hline Rounded Totals & 121465 & 0.03 & $3 \times 10^{-4}$ \\
\hline
\end{tabular}

a. Population estimates for each division are based on the 1990 Census Report for Idaho.

b. These population doses do not include radioactive decay beyond $19.1 \mathrm{~km}$. Population dose is based on maximum individual effective dose equivalent using MESODIF air dispersion model. 
The 1992 MESODIF population dose within each census division (Table VI) was obtained by summing the results from appropriate areas contained within tiose divisions. The total $80-\mathrm{km}$ (50-mi) population dose was the sum of population doses for the various census divisions. The estimated potential population dose was 0.03 person-rem $\left(3 \times 10^{-4}\right.$ person-Sv) to a population of about 121,500 . When compared with an approximate population dose of 42,500 person-rem (425 person-Sv) from natural background radiation, this represents an increase of only about $0.00007 \%\left(7 \times 10^{-5}\right.$ percent $)$. The dose of 0.03 person-rem can also be compared to the following estimated population doses for the same size population: 3600 person-rem for medical diagnostic procedures, about 480 person-rem from exposure to highway and road construction materials " or 6 to 12 person-rem for television viewing. ${ }^{17}$

Table VIl summarizes the calculated annual effective dose equivalents from 1992 INEL operations using both CAP-88 and MESODIF air dispersion models and compares these doses to the EPA airborne pathway standard and to the estimated effective dose equivalent from natural background.

The contribution of game animal consumption to the population dose has not been calculated for most game animals because a small percentage of the population hunts game, few of the animals killed have spent time on the INEL, and most of the animals that do migrate from the INEL have background concentrations of radionuclides in their tissues. The $1984-85$ study $^{21}$ calculated the collective committed effective dose equivalent potentially received by hunters from ducks that had visited the TRA radioactive waste pond was 0.0016 person-rem $\left(1.6 \times 10^{-5}\right.$ person-Sv). The total population dose contribution from ducks is less than the sum of population doses from inhalation of air, submersion in air, and deposition on soil.

\section{TABLE VII \\ SUMMARY OF ANNUAL EFFECTIVE DOSE EQUIVALENTS DUE TO 1992 INEL OPERATIONS}

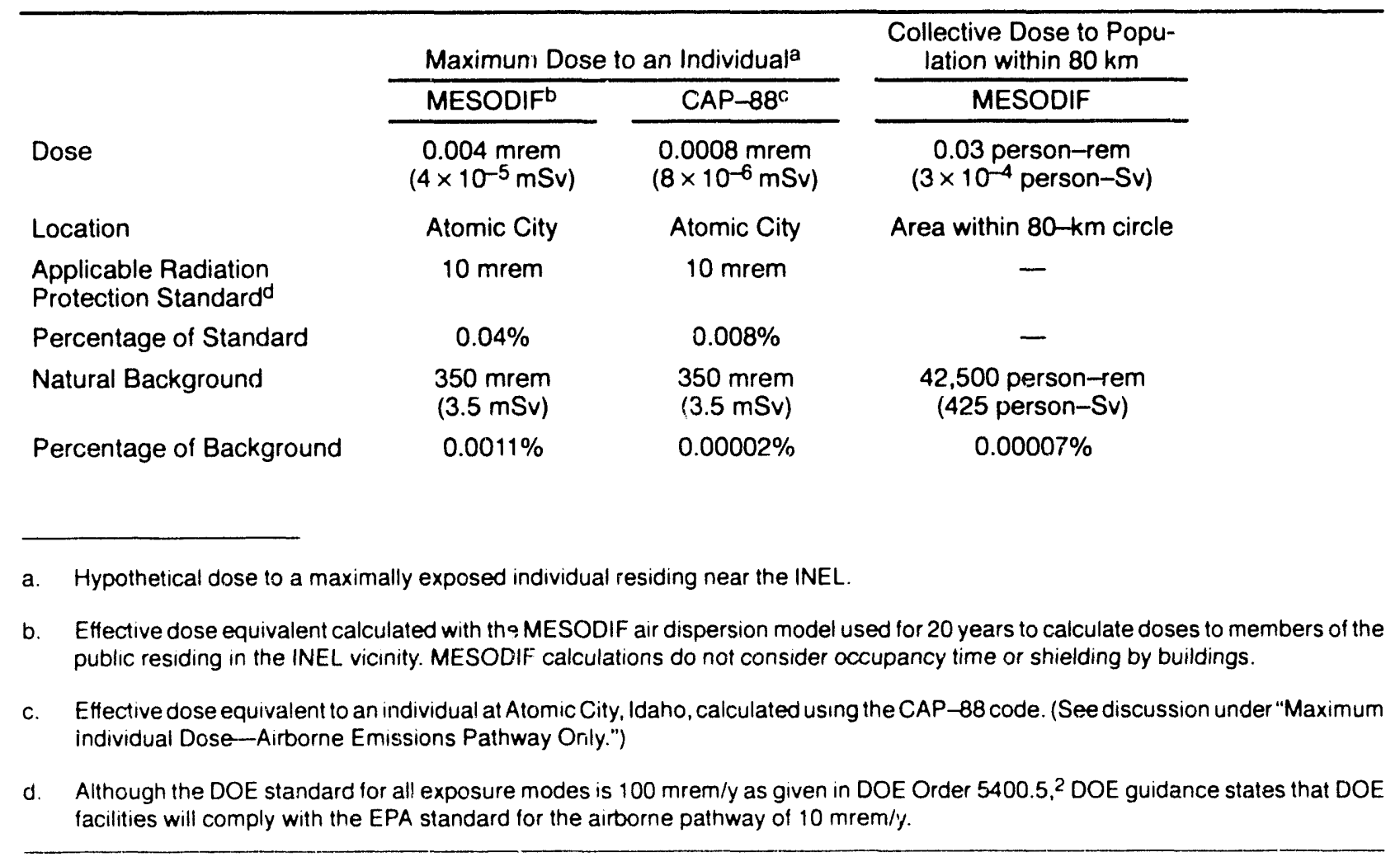




\section{GROUND-WATER SURVEILLANCE PROGRAM INFORMATION}

\section{General U. S. Geological Survey (USGS) Program Information}

No streams or rivers flow from within the INEL to locations outside the boundaries. Therefore, water sampling is limited to onsite and offsite ground-water monitoring plus samples from the Snake River and other surface streams and tributaries in the INEL vicinity, some of which flow onto the Site and sink into its porous soils. A brief description of the hydrogeology of the INEL and the movement of water in the Snake River Plain aquifer is given in Appendix A. Further information may be found in References 4 and 5 . The Snake River Plain aquifer, which lies beneath the INEL, serves as one of the primary sources for drinking water and crop irrigation in the Snake River Basin. Therefore, the USGS has an extensive monitoring program to maintain surveillance of the aquifer and perched water bodies above it on the INEL and at a few locations beyond the southern and western boundaries.

The USGS maintains more than 120 aquifer observation wells on or near the INEL and 45 wells are available for sampling perched ground-water bodies. In addition, more than 120 shallow auger holes have been constructed to monitor shallow perched ground-water bodies. Figures 15 and 16 show USGS sampling locations. Water levels in wells and various radiological and nonradiological substances in water from the aquifer are monitored. References 4 and 5 contain maps showing the frequency of water level measurements and water sample collections, as well as information on the shape and extent of waste plumes (i.e., the spread of various contaminants in the water of the aquifer and perched water from INEL facilities) as they were between 1982 and 1988. Changes which have occurred in the INEL ground water over the sixyear period can be seen in figures and text of these two references.

The USGS routine ground-water surveillance program was summarized in Table III in the section "Environmental Program Information."
However, the USGS also conducts special studies of the ground water of the Snake River Plain that are not included in the Table III summary. These special studies provide more specific geological and hydrological information on the flow and recharge of the aquifer and the movements of radioactive and nonradioactive substances in the ground water. Most of the information from these studies is published in USGS reports.

Results of monitoring or surveillance activities that are published in USGS reports are generally summarized in this annual site environmental report the year of publication but may refer to sampling programs that took place in earlier years. USGS results and information for securing copies of their reports are available upon request from the USGS INEL Project Office at CFA.

The USGS and the Idaho DWR, in response to a request from DOE, ${ }^{27}$ sampled 19 sites as part of a long-term project to monitor water quality of the Snake River Plain aquifer from the southein boundary of the INEL to the Hagerman, Idaho, area. Water samples were collected and analyzed for manmade pollutants and naturally occurring constituents from seven irrigation wells, five domestic wells, two springs, one stock well, two dairy wells, one observation well, and one commercial well.

None of the radionuclides, inorganic constituents, or organic compounds for which the samples were analyzed exceeded the established maximum contaminant levels for drinking water. Dissolved organic carbon (DOC) was reported in all samples at concentrations ranging from 0.3 to $2.2 \mathrm{mg} / \mathrm{L}$, but no maximum contaminant level has been established for DOC. Surfactants were at or above the reporting level in all samples and ranged from 0.01 to $0.07 \mathrm{mg} / \mathrm{L}$. All were below the EPA secondary maximum contaminant level of $0.5 \mathrm{mg} / \mathrm{L}$. Analyses for 36 purgeable organic compounds were negative for all except one sample with a reported toluene concentration of $0.3 \mu \mathrm{g} / \mathrm{L}$, which is about $0.015 \%$ of the EPA proposed maximum contaminant level of $2,000 \mu g^{\prime} \mathrm{L}$. 


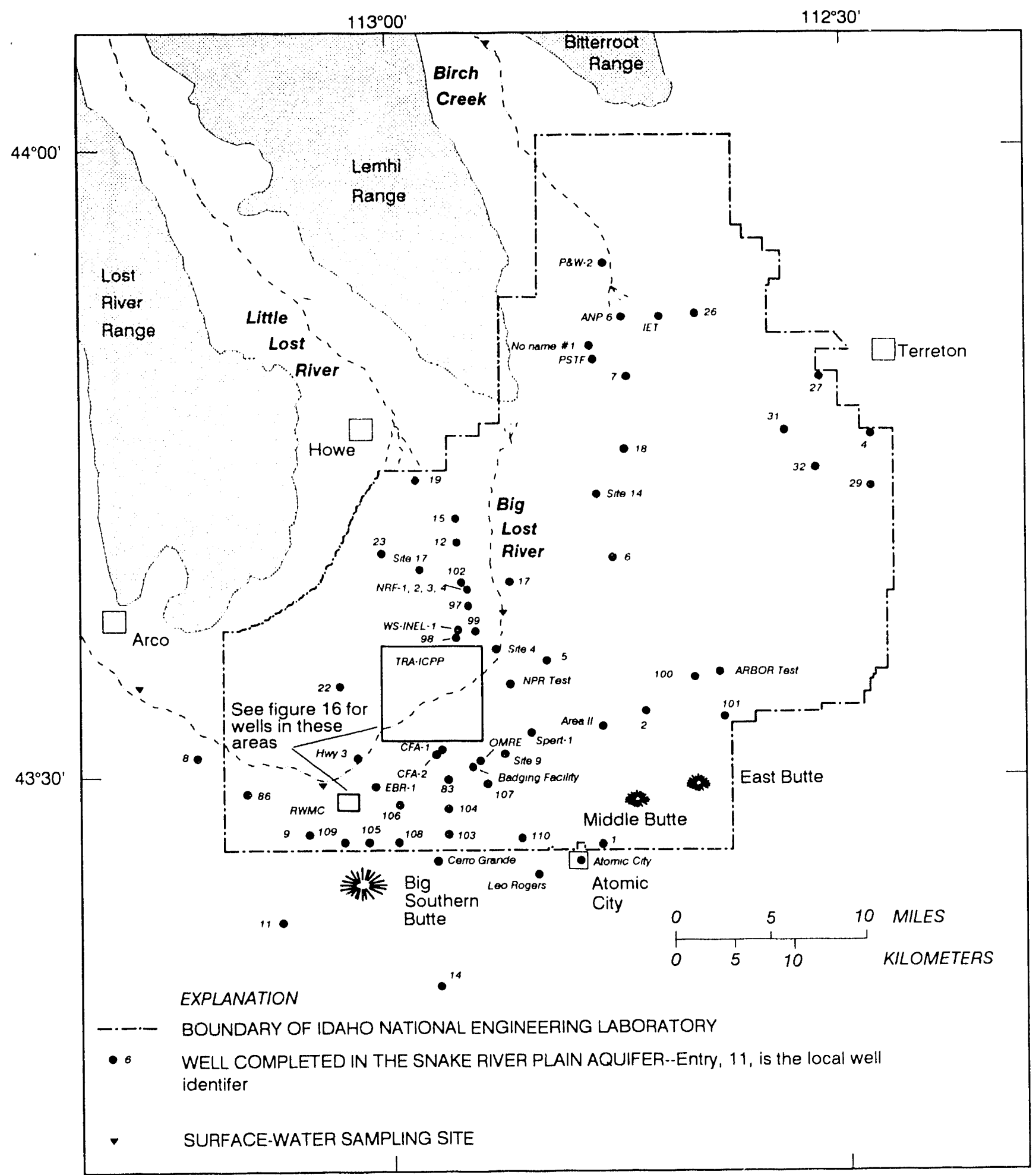

Figure 15. USGS Sample location map for the INEL Site and vicinity. 


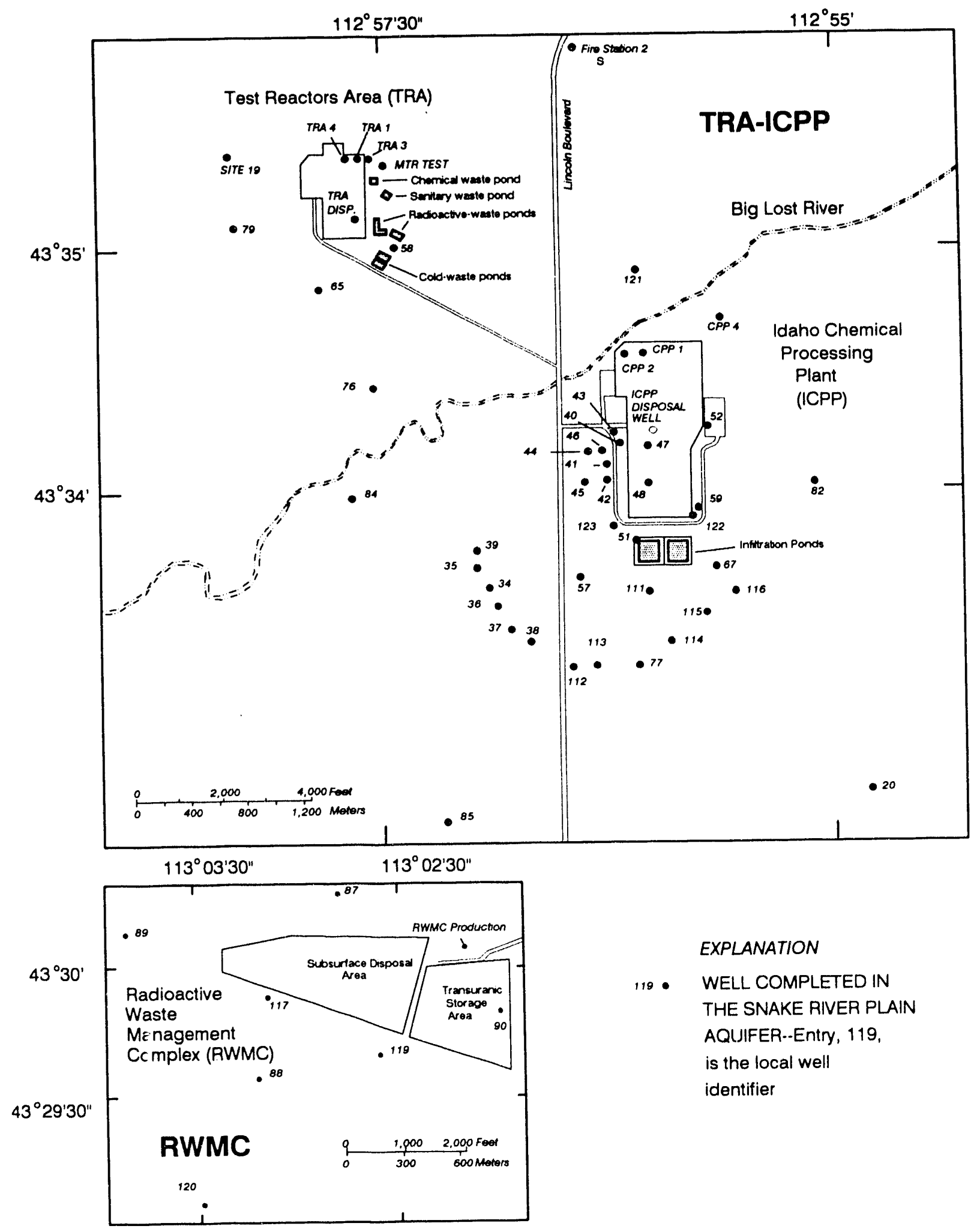

Figure 16. USGS detailed sample location map for ICPP, TRA, and RWMC. 
Samples from two wells in Jerome County, Idaho, had coliform bacteria present at one colony per $100 \mathrm{~mL}$ of water. All the rest of the wells tested were clear of coliform bacteria.

During 1989, water samples were collected from 23 locations in the eastern Snake River Plain by the USGS. ${ }^{28}$ Samples were analyzed for trace elements, major cations, anions, silica, DOC, EDTA, purgeable organic compounds, semivolatile compounds (extractable acid and base/neutral organic compounds), and radioactive parameters including gross alpha, gross beta, gamma-emitting isotopes, $\mathrm{Sr}-\mathbf{9 0}, \mathrm{Rn}-222$, uranium isotopes, and transuranics $(\mathrm{Pu}-238, \mathrm{Pu}-239 / 240$, and Am-241). The data are presented in a number of tables in the referenced report and are too complex to summarize here.

Wastewater containing radiochemical and chemical constituents has been discharged to infiltration ponds and wells at the INEL since 1952. As a result of this disposal practice and specific geologic conditions, perched ground-water zones have formed from this waste water in several areas near major INEL facilities. These zones lie above the aquifer and are sampled routinely by the USGS and results are published periodically. The USGS published a report in 1991 that included data from perched water zones near the ICPP, TRA, and RWMC for 1986-88. ${ }^{29}$ These data and the hydrologic and lithologic data included in the report are complex and beyond the scope of a summary for this annual site environmental report. For specific information, the reader may contact the USGS INEL Project Office at CFA.

The USGS, in response to a request from DOE's Pittsburgh Naval Reactors Office, Idaho Branch Otfice, sampled wells in the NRF vicinity as part of a long-term project to monitor water quality of the Snake River Plain aquifer in the vicinity of the NRF facility on the INEL. The 1989-90 data were reported in June 1992, and the 1990-91 report was published in January 1993.

In the earlier 1989-90 period, samples were collected from 13 sites on the eastern Snake River
Plain in the vicinity of NRF. ${ }^{30}$ Analyses of nonradiological parameters showed that most of the samples contained reportable concentrations of total cations (for example, calcium, potassium, magnesium, and sodium) and dissolved anions (for example, bromide, chloride, sulfate, and fluoride). No semi-volatile priority pollutants were detected; however, samples from nine locations contained tentatively-identified organic compounds at small estimated concentrations. Purgeable organic compounds were reported in water from two wells at the analytical laboratory's $0.2 \mu \mathrm{g} / \mathrm{L}$ minimum reporting level. Detection is questionable at that low concentration. Concentrations of total organic carbon ranged from 0.1 to $0.9 \mathrm{mg} / \mathrm{L}$.

Total phenols slightly above laboratory minimum reporting levels were found in some NRF monitoring wells. However, the quality assurance blank sample of deionized water also indicated elevated total phenols at the $2-4 \mu \mathrm{g} / \mathrm{L}$ level. No detectable levels of individual phenol compounds were found in the analyses for extractable acid and base/neutral organic compounds. Based on these observations, the source of the detectable total phenols is unknown but may be due to analytical variability of the total phenol analysis method at this low reporting level. No herbicides were detected in any of the wells sampled. Cyanazine, a carbamate insecticide, was reported in one sample from USGS 97 at $0.1 \mu \mathrm{g} / \mathrm{L}$. This is the same as the laboratory minimum reporting level, so actual detection of the insecticide is questionable. Concentrations of polychlorinated compounds, for example, PCB, PCN, and arochlors, were not detected in any of the water samples collected.

Concentrations of gross alpha-particle radioactivity as $\mathrm{Th}-230$ (a natural radionuclide) were reportedly above the minimum detectable concentration in six of 13 samples. Gross beta activity was measured in the dissolved fractions of all 13 water samples, but was not detected in the suspended fraction of any. Radium-226, a naturally occurring radionuclide was detected in all samples at concentrations ranging from 4.2 to $9.5 \times 10^{-7} \mu \mathrm{Ci} / \mathrm{mL}$. Radium-228 was not detected in any samples. Tritium concentrations 
reportedly ranged from less than the repcrting level to $180 \times 10^{-9} \mu \mathrm{Ci} / \mathrm{mL}$ distributed about the mean and median values of $89 \times 10^{-9}$ and $93 \times 10^{-9} \mu \mathrm{Ci} / \mathrm{mL}$, respectively. ${ }^{f}$

Water samples during the 1990-91 period were analyzed for manmade contaminants and natural constituents. ${ }^{31}$ Sixty-nine samples were collected from eight ground water monitoring wells and four production wells. The total includes nine quality assurance samples.

Most of the samples contained reportable concentrations of total sodium and dissolved anions. The predominant category of nitrogen-bearing compounds was nitrite plus nitrate as nitrogen. Concentrations of total organic carbon ranged from less than 0.1 to $2.2 \mathrm{mg} / \mathrm{L}$. Total phenols in 52 of 69 samples ranged from 1 to $8 \mu \mathrm{g} / \mathrm{L}$. Semivolatile priority pollutants were detected in two of 69 samples at levels near the laboratory minimum reporting level. Fourteen other samples contained levels of tentatively-identified organic compounds at small estimated concentrations. Pesticides were not detected in any wells.

Concentrations of dissolved gross alpha- and gross beta-particle radioactivity in all samples were near the laboratory's reportable level (minimum detectable concentration). Radium-226 concentrations were reported in 63 of 68 samples with concentrations ranging from 0.16 to $9.75 \times 10^{-10} \mu \mathrm{Ci} / \mathrm{mL}$. Radium-228 was reported in five of the 69 samples at concentrations ranging from 1.6 to $5.4 \times 10^{-10} \mu \mathrm{Ci} / \mathrm{mL}$. Both are naturally occurring radionuclides.

During 1992, USGS personnel collected 395 samples from ground-water and surface-water sites at the INEL, including routine samples summarized in Table III, that were analyzed by the Analytical Chemistry Branch at RESL for radionuclides. Ninety-two samples were sent to the

f. Editorial Note: For comparison purposes, all radionuclide concentrations were well below the EPA maximum contaminant levels for drinking water systems. Only four of the wells sampled are used for drinking water at NRF.
USGS National Water Quality Laboratory (NWQL) in Arvada, Colorado, for nutrient analyses (nitrates, phosphates, etc.), 12 samples for organic compounds, 15 for trace elements, and 481 for common inorganic ions.g

The RESL portion of the routine ground-water surveillance program was described and data were evaluated and summarized in the "Environmental Radiological Program Information" section of this report. USGS data for 1992 are briefly summarized in this "Ground-Water Surveillance Program Information" section. During 1992, INEL contractors also sampled drinking water at the facilities they operate and submitted these samples to laboratories that were certified by the State of Idaho for radiological analyses or that had reciprocity with the State of Idaho. These contractor data are also summarized in this ground-water surveillance section.

\section{Summary of Radiological Surveillance Results}

USGS. Because USGS special studies frequently overlap the subsection titles of this report, five studies published between November 1991 and January 1993 were summarized or described in the preceding section titled "General USGS Program Information."

INEL Contractors. All INEL contractors with liquid effluent streams containing radionuclides sample the waste streams and report the results of analyses on a monthly basis to the RWMIS operated by EG\&G Idaho Environmental Monitoring Unit. Each quarter the RWMIS publishes a report showing the monthly radiological releases at each INEL facility. In the past, each major contractor sampled drinking water wells at their facilities on a quarterly basis once every four years and submitted these samples for gross alpha, gross beta, and tritium analyses to an analytical laboratory certified by the State of Idaho or with reciprocity. Now that the RESL laboratory is certified by the State of Idaho for radiological analyses of drink-

g. Information provided by B. R. Orr, USGS, April 1993. 
ing water, the RESL program serves the purpose of the earlier contractor programs.

In May and July of 1992 EG\&G Idaho elected to sample drinking water locations at their facilities and submitted them to the Accu-Labs Research, Inc. for gross alpha, gross beta, and tritium analyses for comparison to RESL results. Data are shown in Appendix B, Table B-13.

ANL-W. Personnel at ANL-W sampled their seepage pond monthly between April and November of 1992. (The pond is frozen during the winter months.) No detectable concentrations of gross alpha, gross beta, tritium, or gammaemitting radionuclides were found in the 1992 samples. $^{\text {h }}$

\section{Summary of Nonradiological Surveillance Results}

Bacteriological Monitoring. Potable water at the INEL is monitored for coliform bacteria monthly by contractor personnel and analyzed by the EG\&G Idaho Industrial Hygiene Laboratory. Approximately 50 to 60 samples per month are collected from the twelve active drinking water systems at INEL facilities. While "total coliform" bacteria may occasionally be detected in drinking water samples, concern arises only if Escherichia coli $(E$. coli) is present. Although most strains of $E$. coli are not dangerous and are normally found in human and animal intestines, the presence of this organism indicates possible contamination of the water by fecal waste. If even one colony of $E$. coli is found in a sample by the laboratory, that particular drinking water system is cleaned, resampled, and retested until it is clear of bacteria. Corrective action to purify the water may vary somewhat from one facility to another.

In July 1992, EG\&G Idaho samples from the TAN drinking water system were positive for $E$. coli. A sanitary survey or inspection was conducted in an attempt to locate the source of the contamination, the system was flushed, chlori-

h. Information provided by C. T. Martin, ANL-W, April 1993. nated, and then resampled. None of the subsequent samples from either the TAN wells or the drinking water system were contaminated for the rest of 1992.

No $E$. coli colonies were detected in any other INEL drinking water samples during 1992.

The WRC distribution system continued to have an elevated level of general bacteria (not coliform) above the secondary maximum contaminant level of 500 colonies/mL during 1992. EG\&G Idaho conducted an extensive investigation, but the source of the bacteria could not be determined. Plans have been made to treat the system with continual chlorination. Personnel at WRC have been drinking bottled water since the problem began.

\section{Chemical Monitoring.}

USGS. According to a USGS report on background concentrations of chemical constituents, ${ }^{3}$ operations at the INEL have probably affected local concentrations of several purgeable organic compounds: carbon tetrachloride, 1,1,1-trichloroethane, trichloroethylene (TCE), tetrachloroethylene, chloroform, and 1,1-dichloroethylene in the aquifer under the INEL. However, the INEL has apparently had no effect on the concentrations of other purgeable organic compounds, pesticides, or fluoride. In the trace elements group, operations have not affected concentrations of arsenic, barium, cadmium, mercury, and silver; but they may have had a slight effect on the concentrations of dissolved chromium, lead, and selenium.

Sampling for purgeable organic compounds in ground water was conducted by the USGS at the INEL Site during January to December 1992. Water samples from one onsite production well and ten ground-water quality monitoring wells that tap the Snake River Plain aquifer were collected by USGS personnel and submitted to the USGS NWQL in Arvada, Colorado, for analysis for 60 purgeable organic compounds. A 1992 USGS report on the purgeable organic compounds sampling program describes in detail the methods used to collect the water samples and to 
ensure sampling and analytical quality. ${ }^{32}$ In the 1992 USGS set of samples from the INEL, seven purgeable organic compounds were reported at concentrations above the laboratory reporting level of $0.2 \mu \mathrm{g} / \mathrm{L}$ : carbon tetrachloride, chloroform, 1,1,1-trichloroethane, TCE, toluene, dichlorodifluoromethane, and 1,1-dichloroethylene. The only drinking water well sampled by the USGS in 1992 containing purgeable organic compounds was the RWMC production well. The concentrations of purgeable organic compounds are shown in Appendix B, Table B-14 along with the EPA maximum contaminant level for each coinpound on the bottom row of the table. All detected concentrations are well below the regulatory levels.

The USGS monitors for inorganic nonradiological wastes in the aquifer by measuring specific conductance and sodium, chloride, total chromium, trace elements, and nitrate concentrations. All of these waste products were at background levels at least $4 \mathrm{~km}(2.5 \mathrm{mi})$ inside the nearest Site boundary, indicating that detectable concentrations of inorganic contaminants in ground water had not migrated offsite by the end of 1990. ' Concentrations of sodium, chloride, and nitrate ions above background levels have been found downgradient from ICPP, but not offsite. Diagrams for waste plumes of these substances through 1988 are contained in Reference 5. Localized concentrations of total chromium above EPA maximum contaminant levels are present in the aquifer in an observation well (nondrinking water) downgradient from the Test Reactor Area.

Changes in disposal rates and methods for liquid wastes from the ICPP have contributed to changes in the size and configuration of several of the waste plumes. To illustrate, the major nitrate plume which lies below the ICPP has changed markedly. In $1981^{33}$ the size of the ICPP nitrate

i. B. R. Orr, personal communication, USGS, INEL, April 1993. plume, where concentrations exceeded $5 \mathrm{mg} / \mathrm{L}$, was about $26 \mathrm{~km}^{2}\left(10 \mathrm{mi}^{2}\right)$ with a maximum concentration of $62 \mathrm{mg} / \mathrm{L}$. By $1984^{4}$ the size had increased to about $36 \mathrm{~km}^{2}\left(14 \mathrm{mi}^{2}\right)$ with a maximum concentration of $26.9 \mathrm{mg} / \mathrm{L}$ (see Figure 17). However, in 1984 the liquid waste was discharged to infiltration ponds rather than to the injection well, and by $1988^{5}$ the nitrate plume had decreased in size to about $13 \mathrm{~km}^{2}\left(5 \mathrm{mi}^{2}\right)$ with a maximum concentration inside the plume of 24 $\mathrm{mg} / \mathrm{L}$ (see Figure 18).

\section{INEL Contractors.}

ANL-W. ANL-W personnel did not sample production wells at their facility for volatile organic compounds analysis during $1992 . j$

EG\& G Idaho. The EG\&G Idaho Environmental Monitoring Unit routinely samples drinking water from wells and distribution systems at EG\&G Idaho facilities at the INEL for volatile organic compounds. At TAN/TSF, the production wells and distribution systems are sampled more frequently since the discovery in 1987 that the TCE concentrations in samples collected at the wellhead exceeded the maximum contaminant level. (Drinking water samples from the TAN/ TSF distribution system did not exceed the regulatory levels.) A corrective action plan was implemented by installing an aerating device (sparger system) at the point of entry to the distribution system to remove the volatile TCE from the drinking water in the system. The routine monitoring program, which samples the water at the wellhead and in the distribution system has indicated the aeration system works well, and a plan for remedial action to address the localized contamination in the aquifer was developed. Monitoring and treatment will continue as long as is necessary to follow the contaminants already present in the water.

j. Information provided by C. T. Martin, ANL-W, April 1993. 


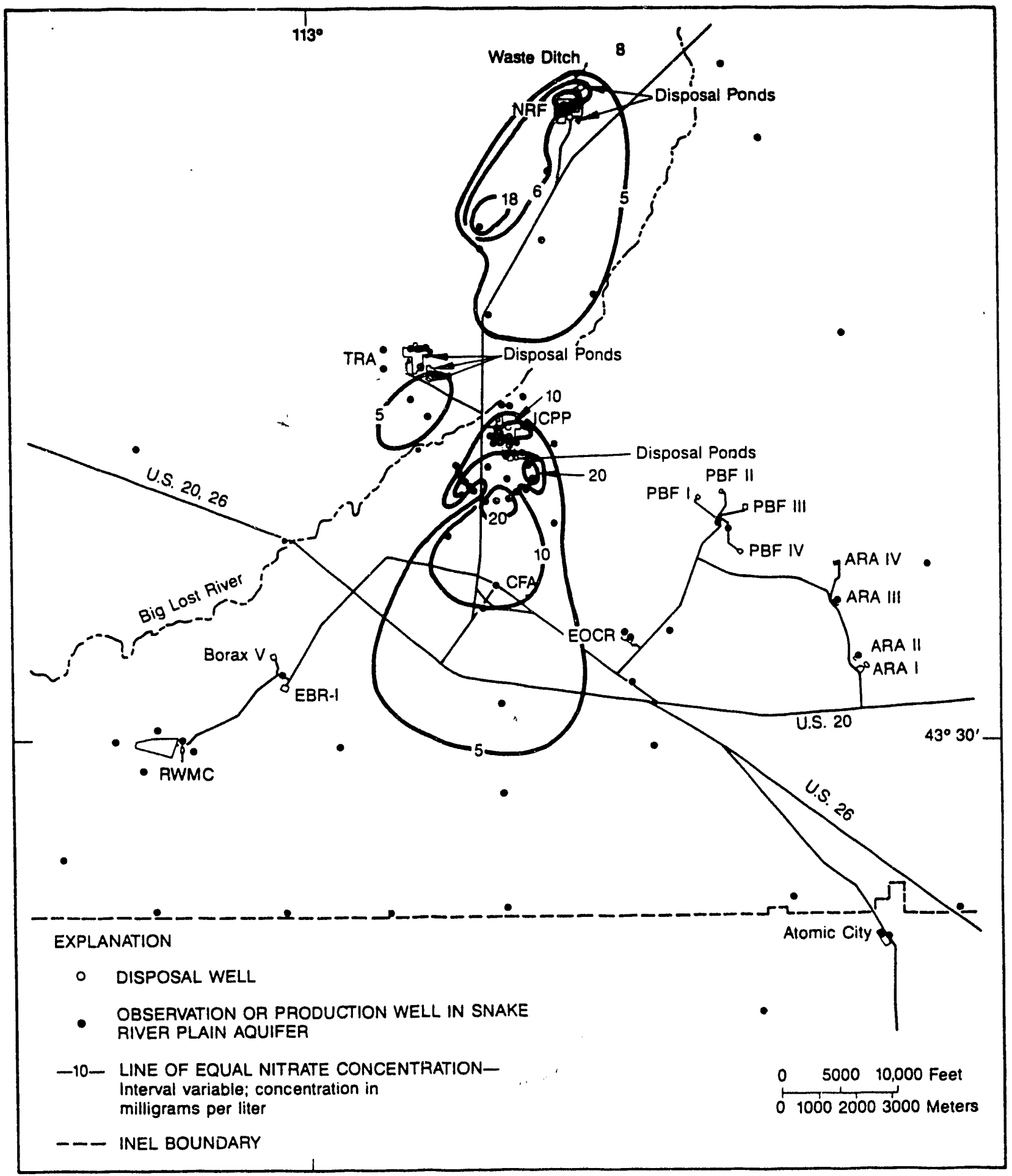

Figure 17. Distribution of nitrate concentrations in the Snake River Plain aquifer in the southcentral part of the INEL, $1984 .^{4}$ 


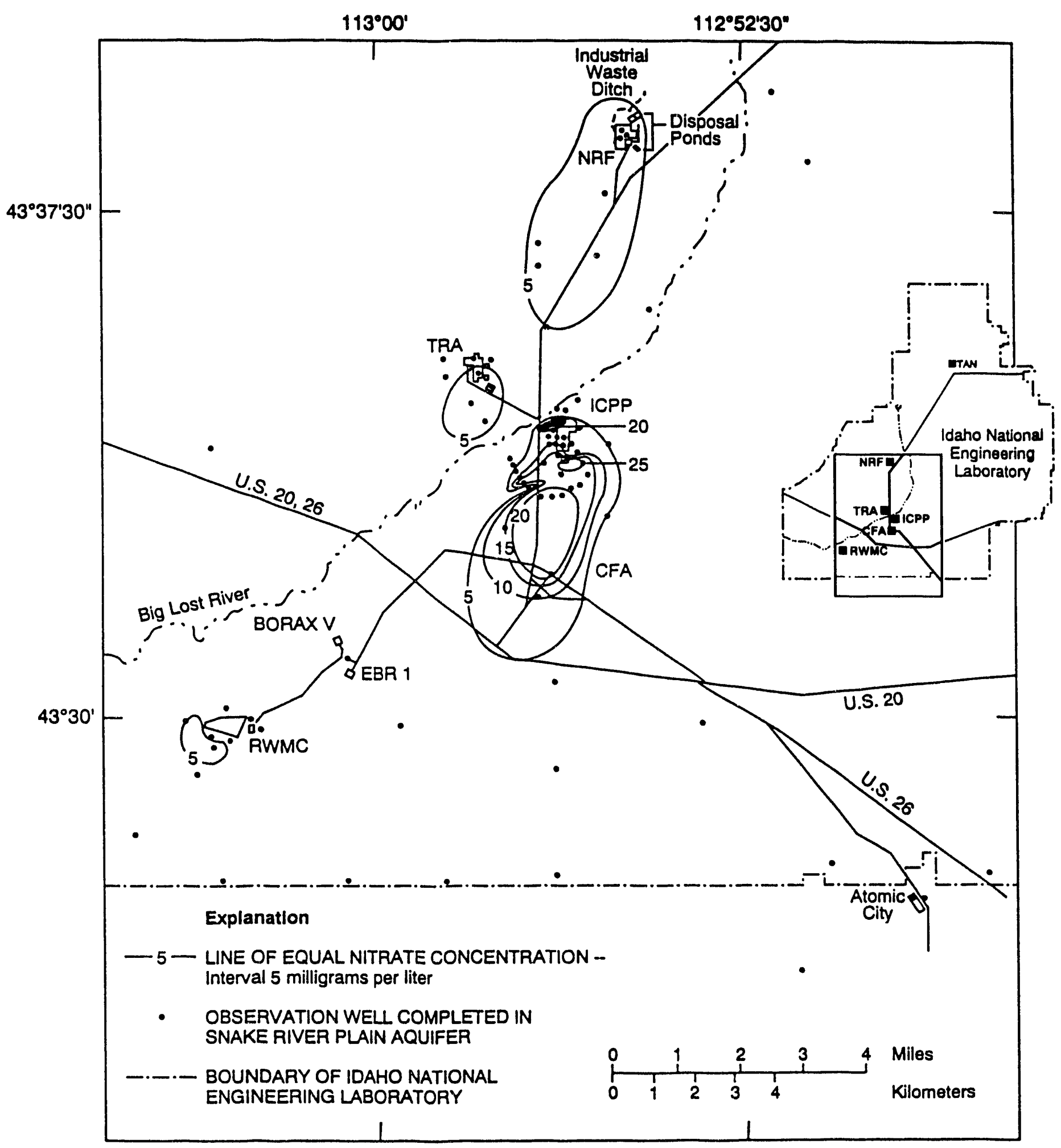

Figure 18. Distribution of nitrate concentrations in the Snake River Plain aquifer in the southcentral part of the INEL, $1988 .^{5}$ 
Data for volatile organic compounds in 1992 EG\&G Idaho samples are shown in Appendix B, Table B-15. Concentrations of TCE in samples from the Water Reactor Research Test Facility (WRRTF) distribution system are above the maximum contaminant level of $5 \mu \mathrm{g} / \mathrm{L}$. However, only bottled water is used by personnel at this facility, so the elevated concentrations of TCE are not of health concern to WRRTF employees. Sampling at WRRTF is conducted for trend and ground-water data information. Data are not used for compliance purposes because personnel do not drink the water from this inactive water system.

In addition to the usual eight regulated volatile organic compounds, the EG\&G Idaho drinking water systems are to be monitored for a period of four quarters for 1,2-dibromoethane and 1,2-dibromo-3-chloropropane. No detectable concentrations of these chemicals were found in the samples collected in June, September, or November 1992. Chlorinated drinking water systems must also be monitored for total trihalomethanes. The June 1992 sample from the CFA distribution system contained a concentration of $4.4 \mu \mathrm{g} / \mathrm{L}$ of these compounds, which is well below the EPA maximum contaminant level of $100 \mu \mathrm{g} / \mathrm{L}$.

During 1992, EG\&G Idaho initiated a semiannual monitoring program for lead and copper levels in drinking water in accordance with EPA regulation 40 CFR 141.80-141.91. Samples were collected May 18-22 and September 14-18, 1992, and analyzed by the Lockheed Analytical Laboratory in Las Vegas, Nevada, according to the same regulations. None of the drinking water samples from EG\&G Idaho facilities exceeded the ninetieth percentile levels for lead or copper. More detailed information and data presentation will be included in the Drinking Water Program 1992 Annual Report, EG\&G-2678(92) which is due to be published in August 1993. ${ }^{\mathrm{k}}$

NRF. Personnel at NRF collected samples during 1992 from production wells \#1, \#2, \#3, and \#4 at NRF and submitted these for analysis for 60 volatile organic compounds. None were detected.'

WINCO. WINCO personnel sample the production and potable wells at the ICPP facility monthly for arsenic, barium, cadmium, chromium, lead, mercury, selenium, silver, chloride, fluoride, nitrate, and sulfate ions. None of these samples exceeded the EPA maximum contaminant levels or State of Idaho drinking water limits during 1992. Data for 1992 are shown in Appendix B, Table B-16.

k. Data provided by Brad Andersen, EG\&G Idaho, March 1993.

1. Data provided by R. D. E. Newbry, U.S. DOE, Pittsburgh Operations Office, Idaho Branch Office, April 1993. 


\section{ENVIRONMENTAL NONRADIOLOGICAL PROGRAM INFORMATION}

\section{Continuous Release Reporting}

In March 1993, DOE-ID performed a sitewide effluent review in an effort to identify any releases which could qualify as CERCLA continuous releases. Questionnaires were completed by INEL contractors and reviewed to identify any possible releases exceeding CERCLA or Emergency Planning and Community Right-To-Know Act (EPCRA) Reportable Quantities. The effort identified no releases which could qualify as CERCLA continuous releases.

\section{Environmental Occurrences}

The Clean Air Act of 1990 made ethylene glycol releases greater than one pound reportable under CERCLA. Releases between two quarts and two gallons of ethylene glycol have occurred at the INEL on January $13,14,22$, and 28, 1992; March 12, 17, and 27, 1992; April 2, 1992; January 1, 1993; and March 11, 1993. The releases were absorbed and disposed of. Notifications were made to the National Response Center (NRC), State Emergency Response Commission (SERC), and Local Emergency Planning Committee (LEPC).

On January 15,1992 , approximately 300 gallons of sulfuric acid was released to the cold waste leaching pond at TRA. The drain valve on an acid tank was jarred open during maintenance. The acid was neutralized, and samples from the pond verified a neutral $\mathrm{pH}$. The release was reported to the NRC, SERC, and LEPC.

On April 1, 1992, it was realized that a corrosion-inhibiting agent routinely used to treat steam condensate at ICPP contained cyclohexylamine, a SARA extremely hazardous substance. Quantities of the cyclohexylamine were released to the environment when condensate was transferred to the percolation ponds. The release was reported to the NRC, SERC, and LEPC. A substitute corrosion-inhibitor which does not contain an extremely hazardous substance is now being used.

\section{SARA Title III Reporting Requirements}

The INEL complies fully with the EPCRA reporting requirements. Quarterly updates to the INEL hazardous substance list, as required by SARA Title III, Section 311, are submitted to the LEPC, the SERC, and the local fire departments on January 1, April 1, July 1, and October 1, annually.

The Emergency and Hazardous Chemical Inventory (Tier II) Reports, as required by SARA Title III, Section 312, were transmitted to the LEPC, SERC, and local fire departments by March 1, 1992, and March 1, 1993.

The Toxic Chemical Release Inventory Report, required by SARA Title III, Section 313, is required for two INEL subcontractors. Reporting thresholds were met for 1,1,1-trichloroethane, nitric acid, and methyl isobutyl ketone. The reports were prepared and submitted to the EPA by July 1, 1992.

\section{Summary of RESL Air Sampling Results}

Atmospheric particulate matter is routinely monitored at the low-volume air sampling stations using the filters previously described. The results for 1992 are given in Appendix B, Table B-17, and a nine-year summary (1984-1992) of results is presented in Table B-18. The analysis involves determining the net weight of the particulate matter on the quarterly composite of weekly filters at each station. The concentrations of the samples ranged from 4 to $50 \mu \mathrm{g} / \mathrm{m}^{3}$. The distant mean was $26 \pm 19 \mu \mathrm{g} / \mathrm{m}^{3}$, the boundary mean was $23 \pm 10 \mu \mathrm{g} / \mathrm{m}^{3}$, and the onsite mean was $13 \pm 2 \mu \mathrm{g} / \mathrm{m}^{3}$. The distant mean is greater than the onsite mean probably because of the amount of resuspended dust from agricultural operations near the distant sampling locations. Most of the airborne particulates in the Site vicinity are windblown dust from the desert floor. 
The revised EPA primary and secondary standard for particulate matter is $50 \mu \mathrm{g} / \mathrm{m}^{3}$, but it applies only to "particulates with an aerodynamic diameter less than or equal to a nominal 10 micrometers." Measurements of total suspended particulates, such as those reported here, will overestimate particulate concentrations in the $10 \mu \mathrm{m}$ and below size range (appear greater than is actually true) in comparison with the new standard. For example, the distant mean of $26 \mu \mathrm{g} / \mathrm{m}^{3}$ appears to be $52 \%$ of the standard, whereas the actual percentage is lower. The standard applies only to particles on the filter with diameters of $10 \mu \mathrm{m}$ or less, but many of the particles on the RESL filters are actually larger than that size because there is no device on the samplers to screen out the larger particles. Particles larger than $10 \mu \mathrm{m}$ are not considered by the EPA to be respirable by humans because they do not usually enter the lungs with inhaled air. The larger particles usually fall out before they reach the nose, are trapped by nasal hairs, or are impacted on tissues of the nasopharynx and passed through the body via the digestive system.

To fulfill one of the conditions specified in the Permit to Construct the Fuel Processing Restoration facility, two nitrogen oxide monitoring stations were activated by RESL. One sampler is located near the intersection of US Highway 20/26 and VANB, and the second is at EFS. The analyzers used are EPA equivalent methods. The VANB sampler operated satisfactorily only $76 \%$ of the time during the first quarter, but about $90 \%$ for the year. At VANB, the annual mean concentration of $\mathrm{NO}_{2}$ for 1992 was about $5 \mu \mathrm{g} / \mathrm{m}^{3}$ ( $5 \%$ of the applicable EPA standard). At EFS, the sampler operated satisfactorily about $88 \%$ of the time. The 1992 annual mean concentration for $\mathrm{NO}_{2}$ at EFS was $13 \mu \mathrm{g} / \mathrm{m}^{3}$ (13\% of the standard). At these locations, the mean concentrations of these gases are calculated to be greater than at the nearest Site boundary in the directions of the prevailing winds. However, even at the onsite locations both annual means are well below the national primary ambient air quality standard of $100 \mu \mathrm{g} / \mathrm{m}^{3}$.
Ambient sulfur dioxide, measured at VANB, had an annual mean concentration of $0.82 \mu \mathrm{g} / \mathrm{m}^{3}$ (about $1 \%$ of the EPA annual standard). The highest quarterly mean concentration occurred during the third quarter 1992 at $1.3 \mu \mathrm{g} / \mathrm{m}^{3}(1.6 \%$ of the EPA standard). The $\mathrm{SO}_{2}$ sampler operated satisfactorily about $93 \%$ of the time it was online during 1992.

RESL calculates the maximum sulfur dioxide and nitrogen dioxide concentrations at the Site boundary each year using the total annual dis-, charges as reported by the INEL Nonradiological Waste Management Information System (INWMIS), ${ }^{m}$ and the MESODIF air dispersion model ${ }^{15}$ (see Figure 13). The calculational method is essentially the same as described in the section "Assessment of Potential Radiation Dose to the Public-General," using mass units for releases instead of radioactivity units.

Emissions of sulfur dioxide from heating oils are calculated from sulfur content and the amount of fuel used at all INEL facilities and are reported to the INWMIS. RESL calculates emissions of nitrogen oxides from fuel by using emission factors developed by the EPA ${ }^{34}$ and the amount and type of fuel burned at each facility as reported by the INWMIS. Motor vehicle exhausts and fugitive dusts are not monitored at their sources.

Total sulfur dioxide released in 1992, shown in Appendix B, Table B-19, was about 117 megagrams ( $\mathrm{Mg})$. For perspective, an $\mathrm{Mg}$ is also sometimes referred to as a metric ton and is equivalent to 2200 pounds. The maximum concentration of sulfur dioxide at the southern INEL boundary. where the MESODIF model predicted the highest concentration, was $0.2 \mu \mathrm{g} / \mathrm{m}^{3}$, which is $0.3 \%$ of the national primary ambient air quality standard of $80 \mu \mathrm{g} / \mathrm{m}^{3}$.

The releases of nitrogen oxides during 1992 are also shown in Appendix B, Table B-19. The total released was about $147 \mathrm{Mg}$. The calculated maximum Site boundary concentration of nitrogen

$\mathrm{m}$. Preliminary INEL industrial waste management data, 1992. 
dioxide was $0.3 \mu \mathrm{g} / \mathrm{m}^{3}$ from all INEL sources. This concentration is $0.3 \%$ of the national primary ambient air quality standard of $100 \mu \mathrm{g} / \mathrm{m}^{3}$.

In May 1992, a new sampler for nonradiological parameters in air was established at CFA. A second was located at Craters of the Moon National Monument and is operated unaur a Memorandum of Understanding between DOE-ID and the National Park Service. These samplers collect ine pariculates witn diameters less than $2.5 \mu \mathrm{m}$ and are analyzed by the Crocker Nuclear Laboratory, University of California at Davis, California. The particulates on the filters are analyzed for mass, optical absorption, elements from sodium through lead on the Periodic Table, plus hydrogen, carbon, nitrogen, und oxygen. 1992 analytical data were not available in time for interpretation and inclusion in this report. Data for the INEL and the Craters of the Moon samplers for 1992 and 199? will be reported next year. Information from these samplers is expected to assist in determining the extent and causes of visibility impairment in the INEL vicinity and at Craters of the Moon National Monument.

\section{Summary of Contractor Nonradioactive Effluent Monitoring}

Nonraciological airborne effluents. Nonradioartive airborne effluents originate from five primary sources at the INEL: calcination of highlevel radioactive liquid waste at New Waste Calcining Facility (NWCF), combustion of coal for steam generation at Coal-Fired Steam Generating Facility (CFSGF), combustion of fuel oil for heating at all INEL facilities, motor vehicle exhausts, and fugitive dusts from waste burial and construcion activities.

Nitrogen oxide emissions are routinely monitored by WINCO at the NWCF, and sulfur dioxide, nitrogen oxides, and carbon oxides are monitored at the CFSGF. (The NWCF and CFSGF facilities are located at ICPP.) These monitoring data are published in the INWMIS quarterly reports.
ANL-W. At ANL-W, the Experimental Breeder Reactor-II (EBR-II) Auxiliary Boilers do not require continuous monitoring because they are below the State of Idaho's 250 million BTU/hr monitoring limit. However, the boiler emissions are monitored monthly as an efficiency check and to ensure that $\mathrm{NO}_{\mathrm{x}}$ and $\mathrm{SO}_{2}$ levels are below State-imposed emission limits. Personnel use a portable stack emission monitor that gives a direct printout of ambient and stack temperature, carbon monoxide, carbon dioxide, sulfur dioxide, nitrogen oxides, and oxygen. If any parameter is measured outside its prescribed limits, the boiler is checked for improper operation and corrective action is initiated. During 1992, the $\mathrm{NO}_{x}$ analyses ranged from 21 to 44 parts per millic.. .ppm) (about 39 tc $83 \mathrm{mg} / \mathrm{m}^{3}$ ), and $\mathrm{SO}_{2}$ ranged between 0 and $167 \mathrm{ppm}$ (0 to $440 \mathrm{mg} / \mathrm{m}^{3}$ ). The monitor was out of service during February and March of $1992 .^{n}$

At the SMC facility, nonradiological airborne effluents include particulate matter, nitrogen oxides, sulfur dioxide, carbon monoxide, volatile organic compounds, and toxic air pollutants. B\&W Idaho personnel have determined that pariculate matter originates from combustion scurces, manufacturing procesces, emergency generators, welding sources, an incinerator, and a carpenter shop. Emissions of $\mathrm{NO}_{\mathrm{x}}, \mathrm{SO}_{2}$, and $\mathrm{CO}$ are generated primarily from boiler and generator operations. In addition, an acid etch process also produces some $\mathrm{NO}_{x}$ emissions that pass through a scrubber and filter system, which removes some of the pollutants before they enter the environment. 7uring 1992, procedures required a minimum of two $\mathrm{NO}_{x}$ grab samples per day using a Draeger tube during operation of the acid-etch process. The acid etch system operated for about 97 days, and the average hourly concentration of $\mathrm{NO}_{\mathrm{x}}$ during operations was $195 \mathrm{ppm}$. When extrapolated throughout the year, the annual hourly average concentration was $22 \mathrm{ppm}$. This concentration equates to about $1.06 \mathrm{ton} / \mathrm{y}$ of nitrogen dioxide released from acid etith operations,

n. Data provided by A. D. Croft, ANL-W, April 1993. 
which is well below the Prevention of Significant Deterioration permitted value of $5.73 \mathrm{tnn} / \mathrm{y}$.

Nonradiological liquid effluents. Nonradioactive liquid effluents are disposed of primarily to a waste ditch at the NRF; seepage ponds at ANL-W, the Containment Test Facility (CTF), TAN, TRA, ICPP, and WRRTF; a lined evaporation pond at PBF; and sewage treatment facilities at various locations. ${ }^{14}$

Routine direct disposal of wastes to the Snake River Plain aquifer ceased in 1984. The only other injection wells on the INEL are used for storm runoff water. Most of these wells are monitored when the storm runoff reaches the level when it flows into the injection well. Potential for contamination via this pathway is small. No waste streams, other than storm water runoff, are discharged directly to the Big Lost River, the only surface stream on the INEL that might conceivably accept waste water.

Other waste effluents are calculated from the amounts of chemicals used for water treatment, corrosir control, and demineralization; as cleansers and algicides; and occasionally from waste acids. Sewage processed by treatment facilities is monitored for biochemical oxygen demand, dissolved oxygen, settleable solids, and $\mathrm{pH}$. Results of monitoring sanitary waste streams for these parameters at all INEL facilities are reported quarterly by the INWMIS.

ANL-W. During 1992, personnel at ANL-W monitored the seepage pond at their facility for targeted organic compounds, cations, anions, $\mathrm{pH}$, and specific conductance. None of the targeted organic compounds were detected in the samples or any of the blanks submitted. The inorganic data are presented in Appendix B, Table B-20."

B\&W Id ho. Most radioactive and hazardous liquid wastes at B\&W Idaho's SMC facility are recycled or processed through a drum evaporator with the final residue disposed as solid waste.

o. Data provided by C. T. Martin, ANL-W, April 1993.
Other hazardous, mixed hazardous, and radioactive wastes are containerized at SAAs within the facility, characterized, and transported to appropriate INEL storage facilities for final preparation and disposal to an offsite facility.

However, boiler effluent and sanitary wastewater were released to the TAN 750 evaporation pond. Presently, DOE and the State of Idaho are negotiating whether the pond is considered a surface water under regulation of the State. Until that determination is made, a sampling program has been established at SMC to collect baseline data for liquid effluent releases. Grab samples were collected during the first quarter of 1992 and analyzed for radioactive and hazardous waste constituents, including heavy metals and corrosivity. Data for nonradiological parameters are presented in Appendix B, Table B-21. The analyses show the waste streams to be nonhazardous and nonradioactive. ${ }^{35}$

Boiler/sanitary waste sampling was temporarily suspended during the second quarter 1992 to resolve LDR issues. In September, a new sampling strategy was issued in anticipation of State Wastewater Land Application permitting requirements. Analytical laboratory personnel at SMC collected monthly boiler and sanitary wastewater samples for extensive analysis of seven conventional and 26 nonconventional pollutants. A field sampling and analysis plan was prepared and analyses that could not be performed by the SMC Analytical Laboratory were contracted to an offsite laboratory. Analytical data for the last four months of the year have been received by the SMC analytical laboratory. However, the data are extensive and must be reviewed and verified by the laboratory and other organizations before publication.

EG\& G Idaho. EG\&G Idaho instituted a Nonradiological Liquid Effluent Monitoring Program in fiscal year 1986 to provide environmental monitoring for nonradioactive parameters and pollutants in liquid waste effluents generated within its facilities at the INEL. The program involves sampling, analysis, and data interpretation carried out under a rigorous quality assurance program. A more complete description of the pro- 
gram-effluent stream descriptions, sampling regimes, analytical methods, and presentation and interpretation of the data-are published annually by EG\&G Idaho.

For the purpose of this annual site environmental report, only 1992 data from one effluent waste stream, Stream 001-TRA Effluent to Cold Waste Pond, are presented in Appendix B, Table B-22. According to EG\&G Idaho, ${ }^{P}$ RCRA metal concentrations were below the applicable regulatory limits for liquid effluent streams at all EG\&G Idaho facilities during 1992.

NRF. At NRF, the sewage waste stream is monitored for more parameters than appear in the INWMIS reports. Therefore, a summary of the

p. Information provided by L. Peterson-Wright, EG\&G Idaho, Inc., May 1993.
1992 monitoring data for the sewage waste stream, including the additional parameters, is presented in Appendix B, Table B-23.

WINCO. The extent of effluent monitoring for liquid waste streams varies depending on the nature of the effluents. The largest INEL effluent stream, the service waste at the ICPP, is monitored by monthly composite samples analyzed for arsenic, barium, cadmium, chromium, lead, mercury, selenium, silver, chloride, fluoride, nitrate, sulfate, conductivity, total dissolved solids, and $\mathrm{pH}$. According to WINCO personnel, all analytical results for 1992 were less than concentrations defined as hazardous waste in 40 CFR 261.24.9 Data for the service waste stream are shown in Appendix B, Table B-24.

q. Data provided by J. Neff, WINCO, April 1993. 


\section{QUALITY ASSURANCE}

A quality control and assurance program is maintained by RESL to ensure consistent and reliable monitoring results. An internal quality control program is maintained by the following:

- Adherence to written procedures for sample collection $^{36}$ and analytical methods 37,38

- Documentation of program changes

- Periodic calibration of instruments

- Equipment performance checks for background and counting rates of standards

- Routine yield determinations of radiochemical procedures

- Replicate samples to determine precision

- Analysis of blind duplicate and replicate samples

- Analysis of quality control standards in appropriate matrices to test accuracy

- Analysis of reagent blanks to verify that there is no radiochemical contamination

- Propagation of random and systematic uncertainties.

The calibration of counting instruments is carefully performed and is traceable to the National Institute of Standards and Technology (NIST). The Analytical Chemistry Branch (ACB) of RESL has participated each year since 1974 , and the new Laboratory Quality Branch (LQB) has participated since 1991 in a Traceability Program with the NIST. Several alpha-, beta-, and gamma-emitting nuclides, generally in liquid media, are determined; and the results are reported directly to NIST. NIST issues a Report of Test in which the ACB and LQB results are compared with the previously undisclosed NIST-certified values. In addition, LQB prepares two traceability samples each year and sends them to NIST for analysis and comparison between the LQB and the NIST measured values. The criterion for traceability is that the ACB and LQB results agree to within five percent of the NIST values. The results for $\mathrm{ACB}$ and $\mathrm{LQB}$ analyses compared to NIST known values for 1992 are given in Table VIII.

During past years, ACB sent samples to other INEL contractors and project office laboratories who voluntarily participated in the INEL Intercomparison Test Program. Results reported by all laboratories were then compared to RESL values. The LQB has assumed responsibility for the continuation of this program.

The ACB has participated each year since 1976 in the Quality Assessment Program (QAP) administered by the DOE Environmental Measurements Laboratory (EML). EML prepares the quality control samples containing various alpha-, beta-, and gamma-emitting nuclides in water, soil, air filter, vegetation, and tissue media and distributes them to numerous DOE contractor laboratories throughout the country. The program is an interlaboratory comparison in that results from the participants are compared with the experimentally determined results of EML. EML issues QAP Reports in which the identities of participating laboratories, their results, and comparison to EML results are presented. RESL results (from ACB and LQB) for 1992 compared to the EML results are reported in Table IX.

In 1992 RESL continued to participate in the EPA EMSL-LV Intercomparison Studies Program for the measurement of radionuclides in drinking water and is currently certified by the State of Idaho for these analyses as required by the National Primary Drinking Water Regulations. 
TABLE VIII

NIST QUALITY ASSURANCE COMPARISON TEST RESULTS

\begin{tabular}{|c|c|c|c|c|c|}
\hline \multirow{2}{*}{\multicolumn{2}{|c|}{$\begin{array}{c}\begin{array}{c}\text { Reference } \\
\text { Dat: }\end{array} \\
-\frac{10-02-91}{}\end{array}$}} & \multirow{2}{*}{$\frac{\text { Nuclide }}{\mathrm{Zn}-65}$} & RESL Resulta & NIST Resulta & \multirow{2}{*}{$\begin{array}{c}\begin{array}{c}\text { Ratio } \\
\text { RESL/NIST }\end{array} \\
0.99\end{array}$} \\
\hline & & & $3699 \pm 96 \quad \gamma / \mathrm{s} / \mathrm{g}$ & $3719 \pm 79 \quad \mathrm{r} / \mathrm{s} / \mathrm{g}$ & \\
\hline & $0-27-91$ & $M n-54$ & $17660 \pm 371 \gamma / \mathrm{s} / \mathrm{g}$ & $18479 \pm 144 \mathrm{\gamma} / \mathrm{s} / \mathrm{g}$ & 0.96 \\
\hline \multirow{11}{*}{\multicolumn{2}{|c|}{$05-26-92^{c}$}} & 88.0 & $530.5 \pm 26.0 \gamma / \mathrm{s} / \mathrm{g}$ & $530.4 \pm 14.3 \gamma / \mathrm{s} / \mathrm{g}$ & 1.00 \\
\hline & & 122.1 & $427.2 \pm 15.0 \gamma / \mathrm{s} / \mathrm{g}$ & $436.7 \pm 10.5 \gamma / \mathrm{s} / \mathrm{g}$ & 0.98 \\
\hline & & 165.9 & $391.5 \pm 12.5 \gamma / \mathrm{s} / \mathrm{g}$ & $399.9 \pm 8.4 \gamma / \mathrm{s} / \mathrm{g}$ & 0.98 \\
\hline & & 279.2 & $349.9 \pm 11.9 \gamma / \mathrm{s} / \mathrm{g}$ & $351.1 \pm 9.8 \gamma / \mathrm{s} / \mathrm{g}$ & 1.00 \\
\hline & & 391.7 & $1113 \pm 60 \quad \gamma / \mathrm{s} / \mathrm{g}$ & $1104 \pm 31 \quad \gamma / \mathrm{s} / \mathrm{g}$ & 1.01 \\
\hline & & 514.0 & $1103 \pm 25 \quad \gamma / s / g$ & $1108 \pm 34 \quad \gamma / s / g$ & 1.00 \\
\hline & & 661.6 & $2431 \pm 75 \quad \gamma / s / g$ & $2451 \pm 56 \quad \gamma / s / g$ & 0.99 \\
\hline & & 898.0 & $2904 \pm 122 \gamma / \mathrm{s} / \mathrm{g}$ & $2963 \pm 62 \quad \gamma / s / g$ & 0.98 \\
\hline & & 1173.2 & $3190 \pm 57 \quad \gamma / \mathrm{s} / \mathrm{g}$ & $3213 \pm 64 \quad \gamma / \mathrm{s} / \mathrm{g}$ & 0.99 \\
\hline & & 1332.5 & $3213 \pm 84 \quad \gamma / s / g$ & $3225 \pm 58 \quad \gamma / \mathrm{s} / \mathrm{g}$ & 1.00 \\
\hline & & 1836.0 & $3088 \pm 127 \mathrm{r} / \mathrm{s} / \mathrm{g}$ & $3107 \pm 65 \quad \gamma / s / g$ & 0.99 \\
\hline & $5-27-92$ & Th-232 & $133.9 \pm 5.5 \mathrm{~Bq} / \mathrm{g}$ & $133.6 \pm 1.9 \mathrm{~Bq} / \mathrm{g}$ & 1.00 \\
\hline & $6-10-92$ & $\mathrm{H}-3$ & $2250 \pm 68 \quad \mathrm{~Bq} / \mathrm{g}$ & $2220 \pm 19 \quad \mathrm{~Bq} / \mathrm{g}$ & 1.01 \\
\hline & $9-17-92$ & Ru-106 & $657.4 \pm 15.1 \gamma / \mathrm{s} / \mathrm{g}$ & $671.3 \pm 47.9 \gamma / \mathrm{s} / \mathrm{g}$ & 0.98 \\
\hline a. & \multicolumn{5}{|c|}{$\begin{array}{l}\text { Results } \pm \text { overall uncertainty are given. The overall uncertainty is three times the combined uncertainty (the quadratic sum of all ran- } \\
\text { dom and systematic uncertainties at the one standard deviation level). One Bq equals } 2.7 \times 10^{-5} \mu \mathrm{Ci} \text {. }\end{array}$} \\
\hline b. & \multicolumn{5}{|c|}{ Comparison ratio in which the RESL value is divided by the NIST value. } \\
\hline c. & \multicolumn{5}{|c|}{ Specific gamma ray energy in keV. } \\
\hline
\end{tabular}


TABLE IX

DOE ENVIRONMENTAL MEASUREMENTS LABORATORY QUALITY

ASSURANCE PROGRAM RESULTS COMPARISON

\begin{tabular}{|c|c|c|c|c|c|c|c|c|}
\hline \multirow[b]{2}{*}{$\begin{array}{l}\text { Sample } \\
\text { Medium }\end{array}$} & \multirow[b]{2}{*}{ Units } & \multirow[b]{2}{*}{ Radionuclide } & \multirow[b]{2}{*}{$\underset{\text { ID\# }}{\text { RESL }}$} & \multicolumn{2}{|c|}{ RESL } & \multicolumn{2}{|c|}{$\mathrm{EML}^{\mathrm{a}}$} & \multirow[b]{2}{*}{$\begin{array}{l}\text { Ratio } \\
\text { RESLEMLC }\end{array}$} \\
\hline & & & & Value & $\begin{array}{l}\text { Uncertainty } \\
(\%)^{b}\end{array}$ & Value & $\begin{array}{c}\text { Uncertainty } \\
(\%)\end{array}$ & \\
\hline \multicolumn{9}{|c|}{ (Samples received on or before December 2,1992 ) } \\
\hline \multirow[t]{20}{*}{ Air } & Bq/filter & $\mathrm{Be}-7$ & 1 & 284 & 4 & 308 & 2 & 0.92 \\
\hline & & $\mathrm{Be}-7$ & 2 & 291 & 4 & 308 & 2 & 0.94 \\
\hline & & $M n-54$ & 1 & 25.6 & 3 & 25.9 & 3 & 0.99 \\
\hline & & $M n-54$ & 2 & 25.2 & 3 & 25.9 & 3 & 0.97 \\
\hline & & Co-57 & 1 & 5.33 & 4 & 6.40 & 4 & 0.83 \\
\hline & & Co-57 & 2 & 5.36 & 3 & 6.40 & 4 & 0.84 \\
\hline & & Co-60 & 1 & 3.34 & 5 & 3.06 & 6 & 1.09 \\
\hline & & Co-60 & 2 & 3.27 & 5 & 3.06 & 6 & 1.07 \\
\hline & & Sr-90 & 1 & 0.150 & 19 & 0.137 & 8 & 1.09 \\
\hline & & Cs-134 & 1 & 3.71 & 4 & 3.72 & 2 & 1.00 \\
\hline & & Cs-134 & 2 & 3.56 & 4 & 3.72 & 2 & 0.96 \\
\hline & & Cs-137 & 1 & 6.03 & 4 & 5.82 & 5 & 1.04 \\
\hline & & Cs-137 & 2 & 5.81 & 4 & 5.82 & 5 & 1.00 \\
\hline & & $\mathrm{Ce}-144$ & 1 & 35.7 & 7 & 43.3 & 3 & 0.82 \\
\hline & & $\mathrm{Ce}-144$ & 2 & 36.0 & 7 & 43.3 & 3 & 0.83 \\
\hline & & Pu-238 & 1 & 0.0370 & 5 & 0.0420 & 9 & 0.88 \\
\hline & & Pu-239 & 1 & 0.0430 & 6 & 0.0450 & 6 & 0.96 \\
\hline & & Am-241 & 1 & 0.0330 & 6 & 0.0320 & 6 & 1.03 \\
\hline & $\mu g / f i l t e r$ & U-234 & 1 & 0.0181 & 8 & 0.0166 & 5 & 1.09 \\
\hline & $\mu g / f i l t e r$ & U-238 & 1 & 0.0189 & 7 & 0.0160 & 13 & 1.18 \\
\hline \multirow[t]{28}{*}{ Soil } & $\mathrm{Bq} / \mathrm{kg}$ & $K-40$ & 1 & 391 & 8 & 384 & 3 & 1.02 \\
\hline & & $K-40$ & 2 & 399 & 8 & 384 & 3 & 1.04 \\
\hline & & Cs-137 & 1 & 308 & 3 & 285 & 2 & 1.08 \\
\hline & & Cs-137 & 2 & 313 & 3 & 285 & 2 & 1.10 \\
\hline & & Pu-238 & 1 & 20.7 & 5 & 21.9 & 3 & 0.95 \\
\hline & & Pu-238 & 2 & 2.66 & 7 & 21.9 & 3 & 0.12 \\
\hline & & Pu-238 & 3 & 2.60 & 7 & 21.9 & 3 & 0.12 \\
\hline & & Pu-238 & 4 & 20.0 & 0 & 21.9 & 3 & 0.91 \\
\hline & & Pu-238 & 5 & 20.0 & 3 & 21.9 & 3 & 0.91 \\
\hline & & Pu-238 & 6 & 21.1 & 3 & 21.9 & 3 & 0.96 \\
\hline & & Pu-239d & 1 & 7.03 & 5 & 7.76 & 6 & 0.91 \\
\hline & & Pu-239 & 2 & 0.740 & 9 & 7.76 & 6 & 0.10 \\
\hline & & Pu-239 & 3 & 0.780 & 141 & 7.76 & 6 & 0.10 \\
\hline & & Pu-239 & 4 & 6.80 & 4 & 7.76 & 6 & 0.88 \\
\hline & & Pu-239 & 5 & 7.30 & 4 & 7.76 & 6 & 0.94 \\
\hline & & Pu-239 & 6 & 7.10 & 5 & 7.76 & 6 & C:91 \\
\hline & & $A m-241^{d}$ & 1 & 2.22 & 8 & 1.83 & 11 & 1.21 \\
\hline & & Am-241 & 2 & 0.629 & 174 & 1.83 & 11 & 0.34 \\
\hline & & $A m-241$ & 3 & 0.590 & 186 & 1.83 & 11 & 0.32 \\
\hline & & $A m-241$ & 4 & 2.30 & 8 & 1.83 & 11 & 1.26 \\
\hline & & $A m-241$ & 5 & 2.60 & 7 & 1.83 & 11 & 1.42 \\
\hline & & $A m-241$ & 6 & 2.00 & 5 & 1.83 & 11 & 1.09 \\
\hline & $\mu g / g$ & $U-234^{d}$ & 1 & 31.5 & 3 & 29.2 & 6 & 1.08 \\
\hline & & U-234 & 2 & 0.85 & 129 & 29.2 & 6 & 0.03 \\
\hline & & U-234 & 3 & 0.78 & 141 & 29.2 & 6 & 0.03 \\
\hline & & U-234 & 4 & 30.0 & 3 & 29.2 & 6 & 1.03 \\
\hline & & U-234 & 5 & 30.0 & 3 & 2.9 .2 & 6 & 1.03 \\
\hline & & U-234 & 6 & 32.0 & 3 & 29.2 & 6 & 1.10 \\
\hline
\end{tabular}


TABLE IX. (continued).

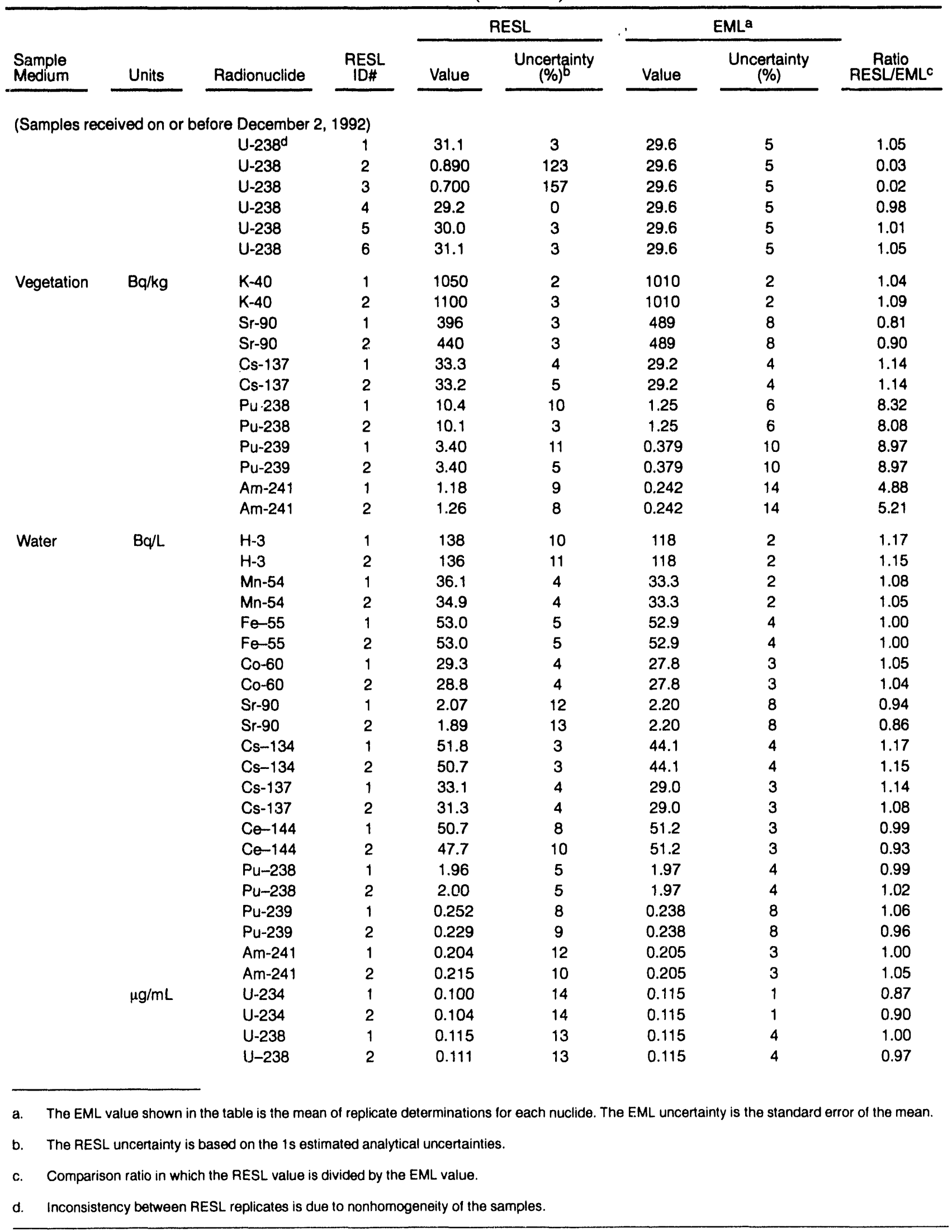


$A C B$ and LQB may also participate in the International Atomic Energy Agency (IAEA) interlaboratory comparisons on those occasions when the IAEA provides sample media of the type and level of radionuclide concentrations normally analyzed in ACB routine procedures. As time or opportunity permits, ACB and LQB participate in the American Society for Testing Materials' round-robin testing of standard methods.

The USGS submits most ground-water samples requiring radioactive analyses to ACB. Samples requiring nonradioactive or organic analyses are submitted to the EPA-certified USGS NWQL in Arvada, Colorado. The INEL USGS Project Office personnel collect, process, and handle all samples according to guidelines specified in a written quality assurance plan for water quality activities. Quality assurance samples submitted to ACB and the NWQL consist of at least $10 \%$ of the total number of samples. Data quality is documented through the use of field logbooks, strict chain-of-custody procedures, and a data verification program for analytical results.

USGS Project Office personnel participate in the USGS's National Field Quality Assurance Program which measures the ability of field personnel to accurately measure $\mathrm{pH}$, specific conductance, and alkalinity. Any deficiencies require retesting and, if necessary, corrective action. Technical reviews of the INEL Project Office water-quality program are conducted on two- to three-year intervals by personnel from USGS National Headquarters in Reston, Virginia; Regional Headquarters in Menlo Park, California; and District Headquarters in Boise, Idaho. Written notification of deficiencies are provided to the Project Chief and corrective actions are required.

Each contractor laboratory which analyzes INEL samples operates quality assurance programs similar to that of ACB and LQB described above including participation in intercomparison programs. When possible, contractors send samples that cannot be analyzed onsite to commercial laboratories with State of Idaho certification or reciprocity.

To verify the quality of the environmental dosimetry program, RESL has participated in eight International Environmental Dosimeter Intercomparison Studies. RESL results were within $10 \%$ of the test exposure values on all intercomparisons. RESL/RSB staff are coordinating the tenth intercomparison and cannot participate in this round.

A Cs-137 calibration source is used for the RESL environmental dosimetry program. The exposure rates for this source are verified quarterly using a transfer chamber calibrated by NIST. Measurement Quality Assurance data show that they agree within $\pm 2.0 \%$ of the NIST values.

DOE Order $5400.1^{1}$ requires that an independent data verification program that covers each element of environmental monitoring and surveillance programs be established by each field organization as a part of the quality assurance program. To meet this requirement for the RESL environmental surveillance program, DOE-ID has established a contract with ISU to conduct an independent environmental surveillance program at the INEL and offsite. Personnel from the ISU Environmental Monitoring Group selected a few RESL sampling locations for air, water, milk, and soil. They collect samples from these locations at the same times that RESL personnel collect samples. The ISU group analyzes their own samples and reports their results plus comparisons to RESL data to the State of Idaho and DOE-ID. Tables X and XI show both ISU and RESL 1992 results for weekly gross alpha and gross beta in air, and gross alpha, gross beta, and tritium in quarterly water samples. The comparison of results shows no serious differences between the laboratories. Those differences seen (particularly with gross beta in air) are most likely due to differences in sampling and analytical methods. The two groups use different types of air samplers for collection and different types of instruments for gross beta analyses. 


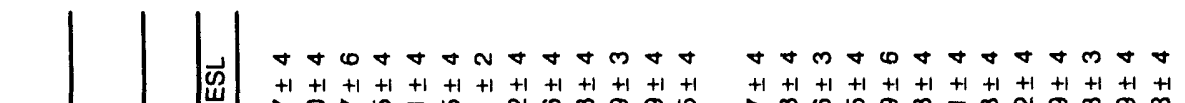 $\frac{m}{2}$

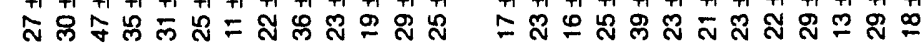

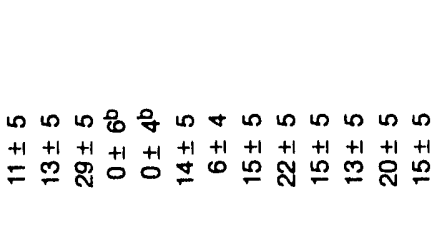

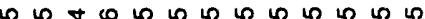

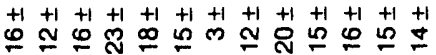

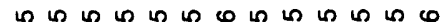

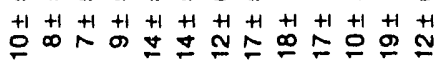 \\ $\forall+0000 \%+\nabla m+\infty$

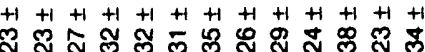

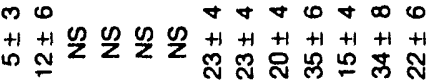

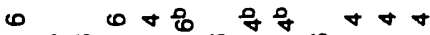

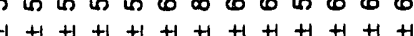

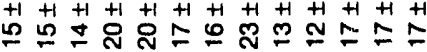 \\ ก

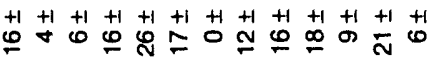

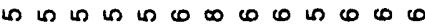

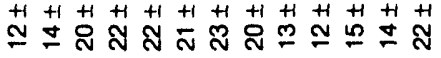

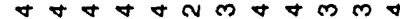 \\ $m m m \forall \forall m \forall \forall m \forall m+\forall$

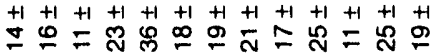

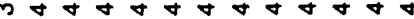

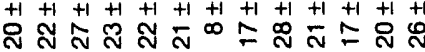

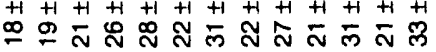 \\ ก ก

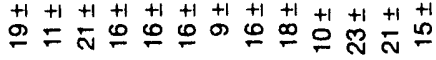

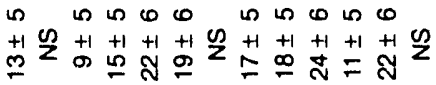

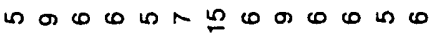 o

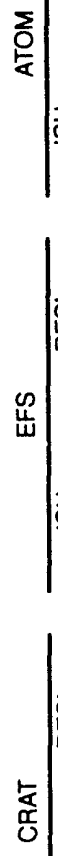 \\ 모

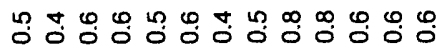

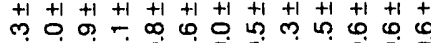

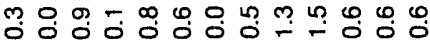

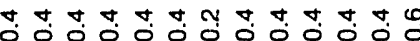 \\ $+1+1+1+1+1+1+1+1+1+1+1+1+1$

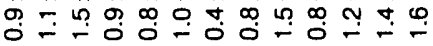

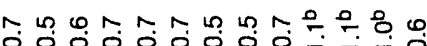

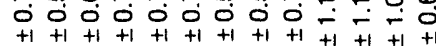

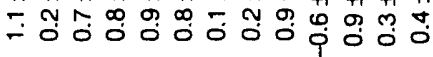

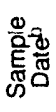

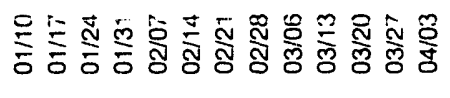 \\ $m \forall m \forall \omega 0 \forall \forall \forall \nabla m \forall \forall$

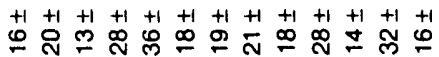

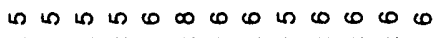 $+1+1+1+1+1+1+1+1+1+1+1+1+1$

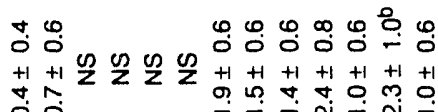

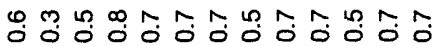 $+1+1+1+1+1+1+1+1+1+1+1+1$

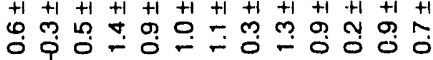

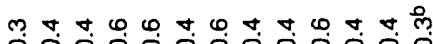

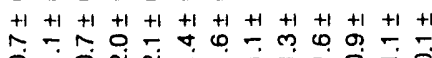

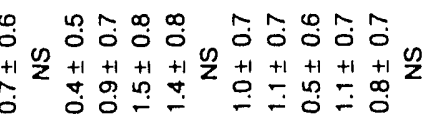 웅영 엉

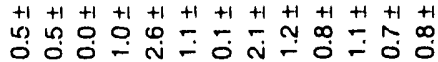 \\ $\nabla \nabla \nabla \omega \nabla \Delta m a \nabla \theta \nabla \nabla$

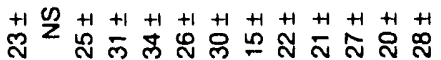 \\ is

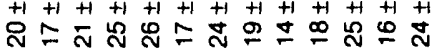

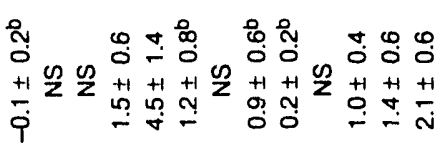

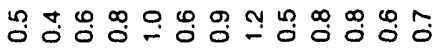

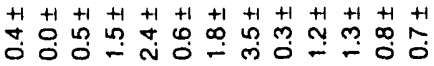

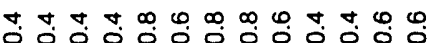

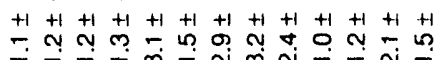 - 0

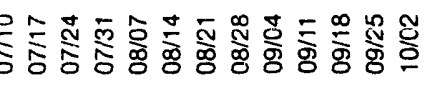




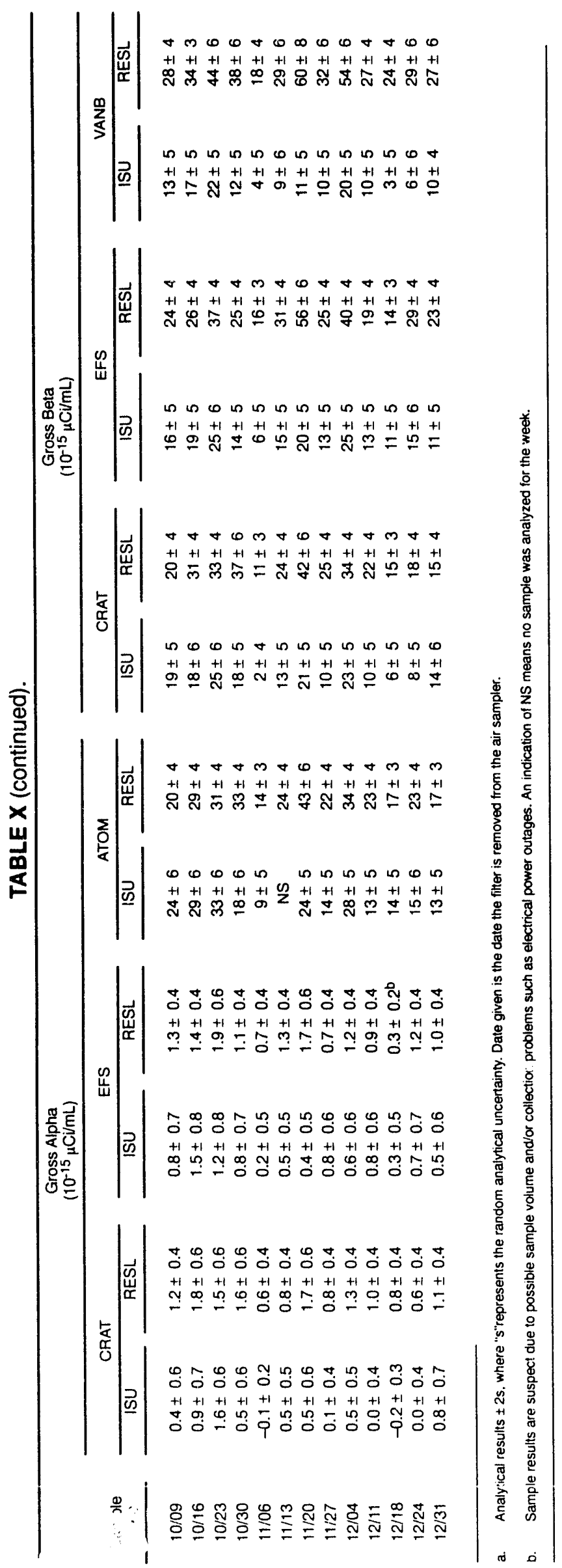




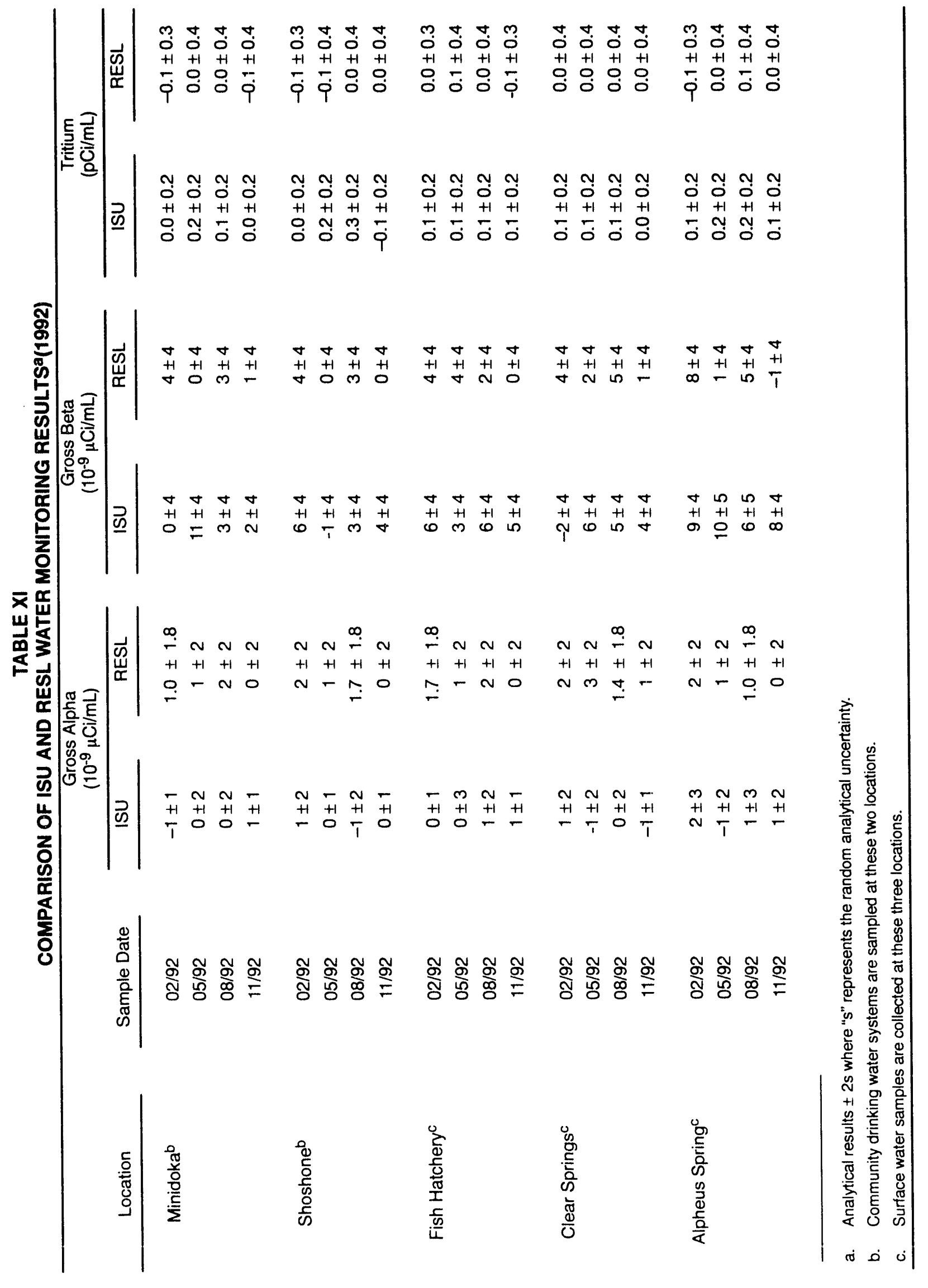




\section{ENVIRONMENTAL STANDARDS AND REGULATIONS}

The following environmental standards and regulations are applicable, in whole or in part, on the INEL Site or at the INEL Site boundary.

U.S. Environmental Protection Agency, "National Primary and Secondary Ambient Air Quality Standards," 40 CFR 50, 1992.

U.S. Environmental Protection Agency, "National Emission Standards for Hazardous Air Pollutants," 40 CFR 61, 1992.

U.S. Environmental Protection Agency, "National Interim Primary Drinking Water Regulations," 40 CFR 141, 1992.

U.S. Environmental Protection Agency, "Hazardous Waste Management System: General," 40 CFR 260, 1992.

U.S. Environmental Protection Agency, "Identifying and Listing of Hazardous Wastes," 40 CFR 261, 1992.

U.S. Environmental Protection Agency, "Standards Applicable to Generators of Hazardous Waste," 40 CFR 262, 1992.

U.S. Environmental Protection Agency, "Standards Applicable to Transporters of Hazardous Waste," 40 CFR 263, 1992.

U.S. Environmental Protection Agency, "Standards for Owners and Operators of Hazardous Waste Treatment, Storage and Disposal Facilities," 40 CFR 264, 1992.

U.S. Environmental Protection Agency, "Interim Status Standards for Owners and Operators of Hazardous Waste Treatment, Storage and Disposal Facilities," 40 CFR 265, 1992.

U.S. Environmental Protection Agency, "Interim Standards for Owners and Operators of New Hazardous Waste Land Disposal Facilities," 40 CFR 267, 1992.

Department of Health and Welfare, State of Idaho, Rules and Regulations for the Control of
Air Pollution in Idaho, 1972, as amended through May 1990.

Department of Health and Welfare, State of Idaho, Idaho Regulations for Public Drinking Water Systems, November 1989.

The principal standards and guides for release of radionuclides at the INEL are those of DOE Order $5400.5,{ }^{2}$ entitled "Radiation Protection of the Public and the Environment." The DOE standard is shown in Table XII along with the EPA standard for protection of the public, airborne pathway only. The DCG from Reference 2 are based on the DOE standard and have been calculated using DOE models and parameters. ${ }^{39,40}$ They are shown in Table XIII. The most restrictive guide is listed when there is a difference between the soluble and insoluble chemical forms. The DCGs consider only the inhalation of air, the ingestion of water, or submersion in air.

Ambient air quality standards are shown in Table XIV. Water quality standards are dependent on the type of drinking water system sampled. Table XV is a partial list of maximum contaminant levels set by the EPA for nontransient noncommunity drinking water systems in 40 CFR 141.

TABLE XII

RADIATION STANDARDS FOR PROTECTION OF THE PUBLIC IN THE VICINITY OF DOE FACILITIES

\begin{tabular}{|c|c|c|}
\hline & \multicolumn{2}{|c|}{ Effective Dose Equivalent } \\
\hline & (mrem/yr) & $(\mathrm{mSv} / \mathrm{yr})$ \\
\hline $\begin{array}{l}\text { DOE Standard for } \\
\text { routine DOE activities a } \\
\text { (all pathways) }\end{array}$ & 100 & 1 \\
\hline $\begin{array}{l}\text { EPA Standard for } \\
\text { site operations } \\
\text { (airborne pathway only) }\end{array}$ & 10 & 0.10 \\
\hline \multicolumn{3}{|c|}{ 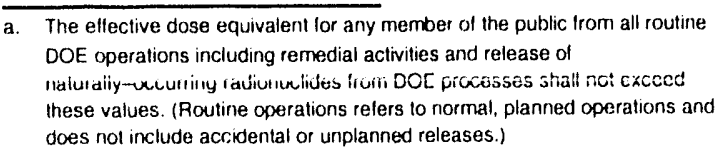 } \\
\hline
\end{tabular}




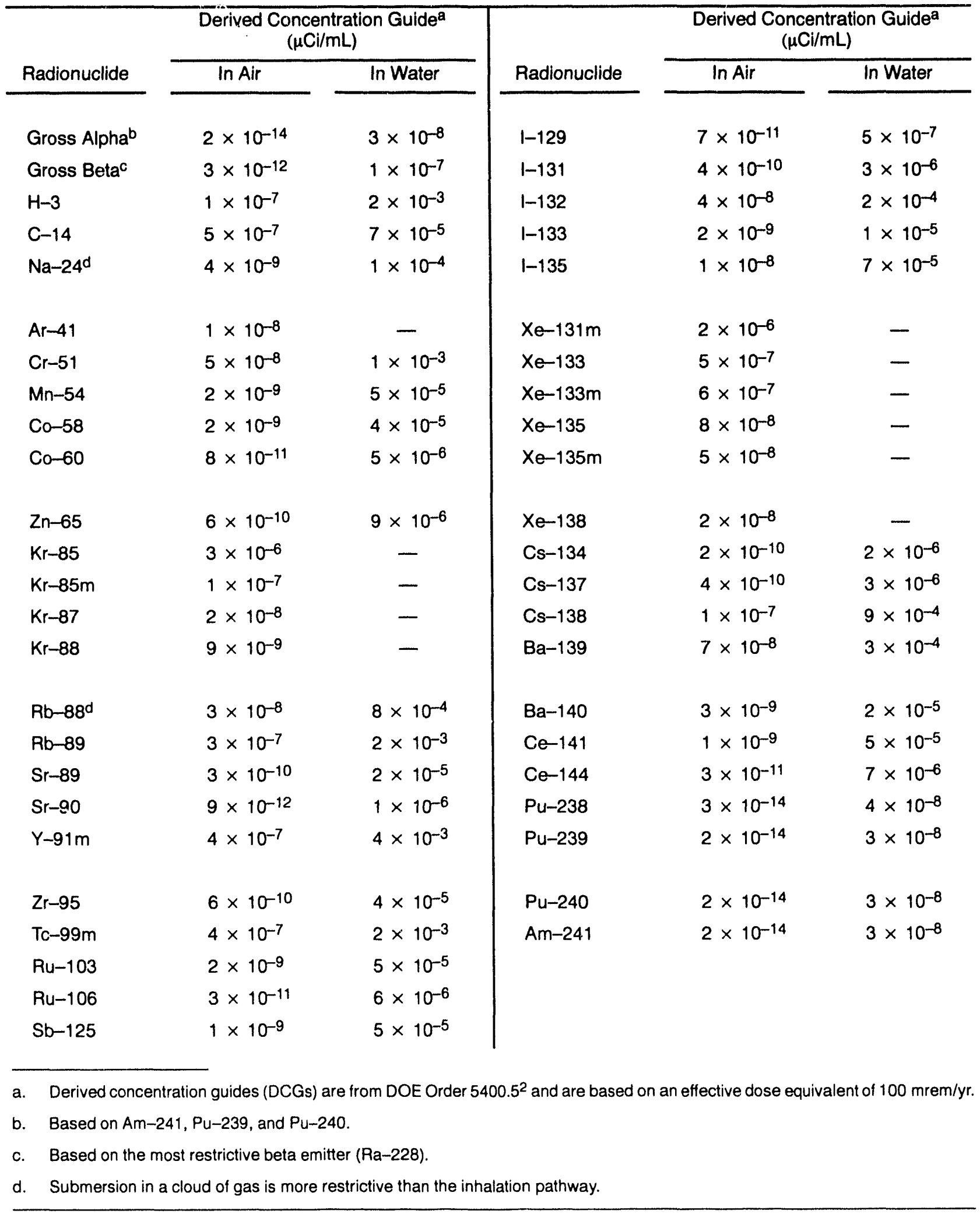


TABLE XIV

\section{AMBIENT AIR QUALITY STANDARDS}

\begin{tabular}{|c|c|c|c|}
\hline Pollutant & Type of Standard ${ }^{a}$ & Sampling Period & $\operatorname{EPA}\left(\mu \mathrm{g} / \mathrm{m}^{3}\right)^{\mathrm{b}}$ \\
\hline \multirow[t]{3}{*}{$\mathrm{SO}_{2}$} & $S$ & 3-hour average & 1300 \\
\hline & $P$ & 24-hour average & 365 \\
\hline & $P$ & Annual average & 80 \\
\hline \multirow[t]{2}{*}{$\mathrm{NO}_{2}$} & S\&P & Annual average & 100 \\
\hline & $S$ & 24-hour average & 150 \\
\hline Total Particulates ${ }^{c}$ & S\&P & Annual average & 50 \\
\hline
\end{tabular}

a. National priman' (P) ambient air quality standards define levels of air quality to protect the public health. Secondary (S) ambient air quality standards define levels of air quality to protect the public welfare from any known or anticipated adverse effects of a pollutant.

b. The State of Idaho has adopted these same ambient air quality standards.

c. The primary and secondary standard for the annual average applies only to "particulates with an aerodynamic diameter less than or equal to a nominal 10 micrometers."

TABLE XV

MAXIMUM CONTAMINANT LEVELS FOR NONTRANSIENT NONCOMMUNITY DRINKING WATER SYSTEMS

\begin{tabular}{ll}
\hline Gross alpha & $1.5 \times 10^{-8} \mu \mathrm{Ci} / \mathrm{mL}$ \\
Gross beta & $5.0 \times 10^{-8} \mu \mathrm{Ci} / \mathrm{mL}$ \\
Manmade radionuclides & Concentrations resulting in 4 mrem total body or organ dose equivalent \\
Nitrate (as N) & $10 \mathrm{mg} / \mathrm{L}$ \\
Fluoride & $4.0 \mathrm{mg} / \mathrm{L}$ \\
Trihalomethanes (Chloroform) & $0.100 \mathrm{mg} / \mathrm{L}$ \\
Carbon Tetrachloride & $0.005 \mathrm{mg} / \mathrm{L}$ \\
Tetrachloroethylene & $0.005 \mathrm{mg} / \mathrm{L}$ \\
Toluene & $1.000 \mathrm{mg} / \mathrm{L}$ \\
1,1,1-trichloroethane & $0.200 \mathrm{mg} / \mathrm{L}$ \\
Trichloroethylene & $0.005 \mathrm{mg} / \mathrm{L}$ \\
Arsenic & $0.05 \mathrm{mg} / \mathrm{L}$ \\
Barium & $2.0 \mathrm{mg} / \mathrm{L}$ \\
Cadmium & $0.005 \mathrm{mg} / \mathrm{L}$ \\
Chromium & $0.10 \mathrm{mg} / \mathrm{L}$ \\
Lead & $0.05 \mathrm{mg} / \mathrm{L}$ \\
Mercury & $0.002 \mathrm{mg} / \mathrm{L}$ \\
Selenium & $0.05 \mathrm{mg} / \mathrm{L}$ \\
Silver & $0.05 \mathrm{mg} / \mathrm{L}$ \\
\hline
\end{tabular}




\section{REFERENCES}

1. "Notification and Reports," Chapter II, U. S. Department of Energy, DOE Order 5400.1, November $9,1988$.

2. "Radiation Protection of the Public and the Environment," U. S. Department of Energy, DOE Order 5400.5, January 7, 1993.

3. B. R. Orr, L. D. F. cil, L. L. Knobel, Background Concentrations of Selected Radionuclides, Organic Compounds, and Chemical Constituents in Groundwater in the Vicinity of the Idaho National Engineering Laboratory, U.S. Geological Survey, Water-Resources Investigations Report 91-4015, DOE/ID-22094, February 1991.

4. J. R. Pittman, R. G. Jensen, and P. R. Fischer, Hydrologic Conditions at the Idaho National Engineering Laboratory, Idaho: 1982 to 1985, U.S. Geological Survey, Water Resources Investigation Report 89-4008, DOE/ID-22078, December 1988.

5. B. R. Orr and L. D. Cecil, Hydrologic Conditions and Distribution of Selected Chemical Constituents in Water, Snake River Plain Aquifer, Idaho National Engineering Laboratory, Idaho, 1986 to 1988 , U.S. Geological Survey, Water Resolirces Investigation Report 91-4047, DOE/ID-22096, March 1991.

6. Federal Register, July 18, 1991, Vol. 56, No. 138, p. 33120.

7. U.S. Environmental Protection Agency, Environmental Radiation Data Report 59, EPA 520/ 5-90-003, March 1990.

8. U.S. Energy Research and Development Administration, Idaho Operations Office, 1976 Environmental Monitoring Report, IDO-12082(76), May 1977, p. 27.

9. D. T. Oakley, Natural Radiation Exposures in the United States, U.S. Environmental Protection Agency, ORP/STD 72-1, 1972, p. 16.

10. R. C. Yoder, et al., Confirmation of Conversion Factors Relating Exposure and Dose-Equivalent Index Presented in ANSI NI3.11, NUREG/CR-1057, PNL-3219: Pacific Northwest Laboratory, Richland, WA, 1979.

11. National Council on Radiation Protection and Measurements, Exposure of the Population in the United States and Canada from Natural Background Radiation, NCRP Report No. 94, December 30, 1987.

12. National Council on Radiation Protection and Measurements, Ionizing Radiation Exposure of the Population of the United States, NCRP Report No. 93, September 1, 1987.

13. O. D. Markham and T. D. Reynolds, eds., Publications of the Idaho National Engineering Laboratory Radioecology and Ecology Program: 1974-1991, DOE/ID-12125, December 1991.

14. U.S. Department of Energy, Idaho Operations Office, Idaho National Engineering Laboratory Environmental Monitoring Plan: Baseline Document, DOE/ID-10395(92), June 1992.

15. G. E. Start and L. L. Wendell, Regional Effluent Dispersion Calculations Considering Spatial and Temporal Meteurological Variations, NOAA Tecnnical Memorandum ERL ARL-44, May 1974. 
16. D. L. Hoff, E. W. Chew, and S. K. Rope, 1986 Environmental Monitoring Program Report for the Idaho National Engineering Laboratory Site, DOE/ID-12082(86), May 1987.

17. United Nations Scientıfic Committee on the Effects of Atomic Radiation Sources and Biological Effects, United Nations: New York, 1982.

18. O. D. Markham, D. K. Halford, S. K. Rope, and G. B. Kuzo, "Plutonium, Am, Cm, and Sr in Ducks Maintained on Radioactive Leaching Ponds in Southeastern Idaho," Health Physics, 55, 3, pp. 517-524.

19. D. F.. Halford, "Effect of Cooking on Radionuclide Concentration in Waterfowl Tissues," Idaho National Engineering Laboratory Radioecology and Ecology Programs, 1983 Progress Report, DOE/ID-12098, June 1983.

20. D. K. Halford et al., "Radionuclide Concentrations" Naterfowl Using a Liquid Radioactive Disposal Area and the Potential Radiation Dose to Man," Health Physics, 40, February 1981, pp. 173-181.

21. R. C. Morris, S. K. Rope, and O. D. Markham, Transport of Radionuclides by Waterfowl Using Wastewater Ponds at the Idaho National Engineering Laboratory, submitted to Health Physics, May 1993.

22. D.K. Halford, O. D. Markham, and R.L. Dickson, "Radiation Doses to Waterfowl using a Liquid Radioactive Waste Disposal Area," Journal of Wildlife Management, 46, pp. 905-914, 1982.

23. J. W. Connelly and O. D. Markham, "Movements and Radionuclide Concentrations of Sage Grouse in Southeastern Idaho," Journal of Wildlife Managemeni, 47, 1, January 1983, pp. 169-175.

24. O. D. Markham and D. K. Halford, "Radionuclides in Mocii ... g Doves Near a Nuclear Facility Complex in Southeastern Idaho," The Wilsor Bulletin, 94, 2, June 1982, pp. 185-195.

25. O. D. Markham and D. K. Halford, "Effects of Decreased Effluents from Nuclear Fuel Reprocessing ori Cs-137 Concentratir s in Wildlife," Northwest Scier `e, 59, 3, August 1985.

26. R. A. Burkhart and D. L. Hoff, POP: A Code for Estimating Populations Around Facilities with Results for the INEL, DOE/ID-12101(85), March 1785.

27. R. C. Bartholomay, D. D. Edwards, and L. J. Campbell; Radionuclides, Inorganic Constituents, Organic Compounds, and Bacteria in Water from Selected Wells and Springs from the Southern Boundary of the Idaho National Engineering Laboratory to the Hagerman Area; Idaho, 1990; DOE/ID-22102; USGS Open-File Report 92-91; March 1992.

28. L. L. Knobel, R. C. Eartholomay, L. D. Cecil, B. J. Tucker, and S. J. Wegner; Chemical Constituents in the Dissolved and Suspended Fractions of Ground Water from Selected Sites, Idaho National Engineering Laboratory, Idaho, 1989; DOE/ID-22101; USGS Open-File Report 92-51; March 1992.

29. L. D. Cecil, B. R. Orr, T. Norton, and S. R. Anderson; Formation of Perched Ground-Water Zones and Concentrations of Selected Chemical Constituents in Water, Idaho National Engineering Laboratory, Idaho, 1986-88; DOE/ID-22100, USGS Water-Resources Investigation Report 91-4166; November 1991 .

30. L. L. Knobel, R. C. Bartholomay, S. J. Wegner, and D. D. Edwards; Chemical Constituents in the Vicinity of the Nuclear Reactors Facility, Idaho National Engineering Laboratory, Idaho, 1989-90; DUE/ID-22103, USGS Open-File Report 92-156; June 1992. 
31. R. C. Bartholomay, L. L. Knobel, and B. J. Tucker; Chemical Constituents in Water from Wells in the Vicinity of the Naval Reactors Facility, Idaho National Engineering Laboratory, Idaho, 1990-91; DOE/ID-22106; USGS Open-File Report 93-34, January 1993.

32. M. J. Liszewski and L. J. Mann, Purgeable Organic Compounds in Ground Water at the Idaho National Engineering Laboratory, Idaho-1990 and 1991, DOE/ID-22104, USGS Open-File Report 92-174, DOE/ID-22089, July 1992.

33. B. D. Lewis and R. G. Jensen, Hydrologic Conditions at the Idaho National Engineering Laboratory, Idaho: 1979-1981 Update, USGS Hydrologic Investigations Atlas HA-674, 1984.

34. U.S. Environmental Protection Agency, Compilation of Air Pollutant Emission Factors, AP-42, Part A, August 1982, p. 1.3-2.

35. D. H. Janke, 1992 Environmental Monitoring Report for the SMC Project, BWRD-044, April 1993.

36. U.S. Department Of Energy, Idaho Operations Office, Radiological and Environmental Sciences Laboratory, Environmental Sciences Branch, Environmental Surveillance Program Manual, 1993.

37. U.S. Department Of Energy, Idaho Operations Office, Radiological and Environmental Sciences Laboratory, Analytical Chemistry Branch, Analytical Chemistry Branch (ACB) Technical Procedures Manual.

38. U.S. Department Of Energy, Idaho Operations Office, Radiological and Environmental Sciences Laboratory, Laboratory Quality Branch, Laboratory Quality Branch $(L Q B)$ Technical Procedures Manual.

39. U. S. Department of Energy, Internal Dose Conversion Factors for Calculation of Dose to the Public, $\mathrm{DOE} / \mathrm{EH}-0071$, July 1988.

40. U. S. Department of Energy, External Dose Conversion Factors for Calculation of Dose to the Public, DOE/EH-0070, July 1988. 


\section{APPENDIX A \\ MAJOR PROGRAMS, LOCATION, GEOLOGY, AND CLIMATOLOGY}


A-2 


\section{APPENDIX A}

\section{MAJOR PROGRAMS, LOCATION, GEOLOGY, AND CLIMATOLOGY}

The INEL Site was established in 1949 as the National Reactor Testing Station to provide an isolated station where various kinds of nuclear reactors and support facilities could be built and tested, and to demonstrate that nuclear energy could be safely harnessed for generating electricity and other peaceful uses. More nuclear reactors have been built at the INEL Site than at any other location in the world. Fifty-two reactors have been built at this Site, twelve of which are operating or operable. The broad mission of the INEL is to develop economic energy sources by applying its engineering and scientific expertise to DOE research and development programs. Major DOE programs currently underway at the INEL Site fall into eight categories:

- Providing test irradiation services from the high-flux ATR

- Recovering uranium from highly enriched spent fuels and calcining liquid radioactive waste solutions into a solid form for storage at the ICPP

- Conducting light-water-cooled reactor safety testing and research

- $\quad$ Operating the EBR-II

- $\quad$ Operating the NRF

- Storing, processing, and monitoring radioactive wastes

- Special manufacturing of defense components

- Conducting environmental restoration at the INEL Site.
See Figure A-1 and Table A-1 for the location of INEL Site facilities and an explanation of their acronyms.

The Site is situated on the upper Snake River Plain in southeastern Idaho at an average elevation of $1500 \mathrm{~m}(4900 \mathrm{ft})$. The Site encompasses $2300 \mathrm{~km}^{2}\left(890 \mathrm{mi}^{2}\right)$; it extends $63 \mathrm{~km}(39 \mathrm{mi})$ from north to south and is about 58-km (36-mi) wide at its broader southern part. Land immediately beyond the boundaries of the Site is either desert or agricultural. Most of the nearby farming is concentrated northeast of the Site. Large areas of agricultural land are farmed in the Snake River Valley, but these regions are more distant from the Site.

The desert plain on which the INEL Site is located is part of a cool, desert-shrub biome. Average annual temperature at the Site is $5.6^{\circ} \mathrm{C}$ $\left(42^{\circ} \mathrm{F}\right)$, with extremes of $39^{\circ} \mathrm{C}\left(103^{\circ} \mathrm{F}\right)$ and $-44^{\circ} \mathrm{C}$ $\left(-47^{\circ} \mathrm{F}\right) .^{\mathrm{A}-1}$ Vegetation is typical of the Gre:t Basin, with sagebrush conspicuous over $80 \%$ of the Site. Frequenting the Site are the pronghorn antelope, a few deer and elk, coyotes, bobcats, rabbits, large populations of small mammals, and various kinds of birds and reptiles. The INEL is one of seven National Environmental Research Parks, where scientists from DOE, other Federal and state agencies, universities, and private research foundations can study changes caused by human activities and obtain data for use in making decisions on land use. At present, about 20 different environmental studies are being conducted at the INEL. 


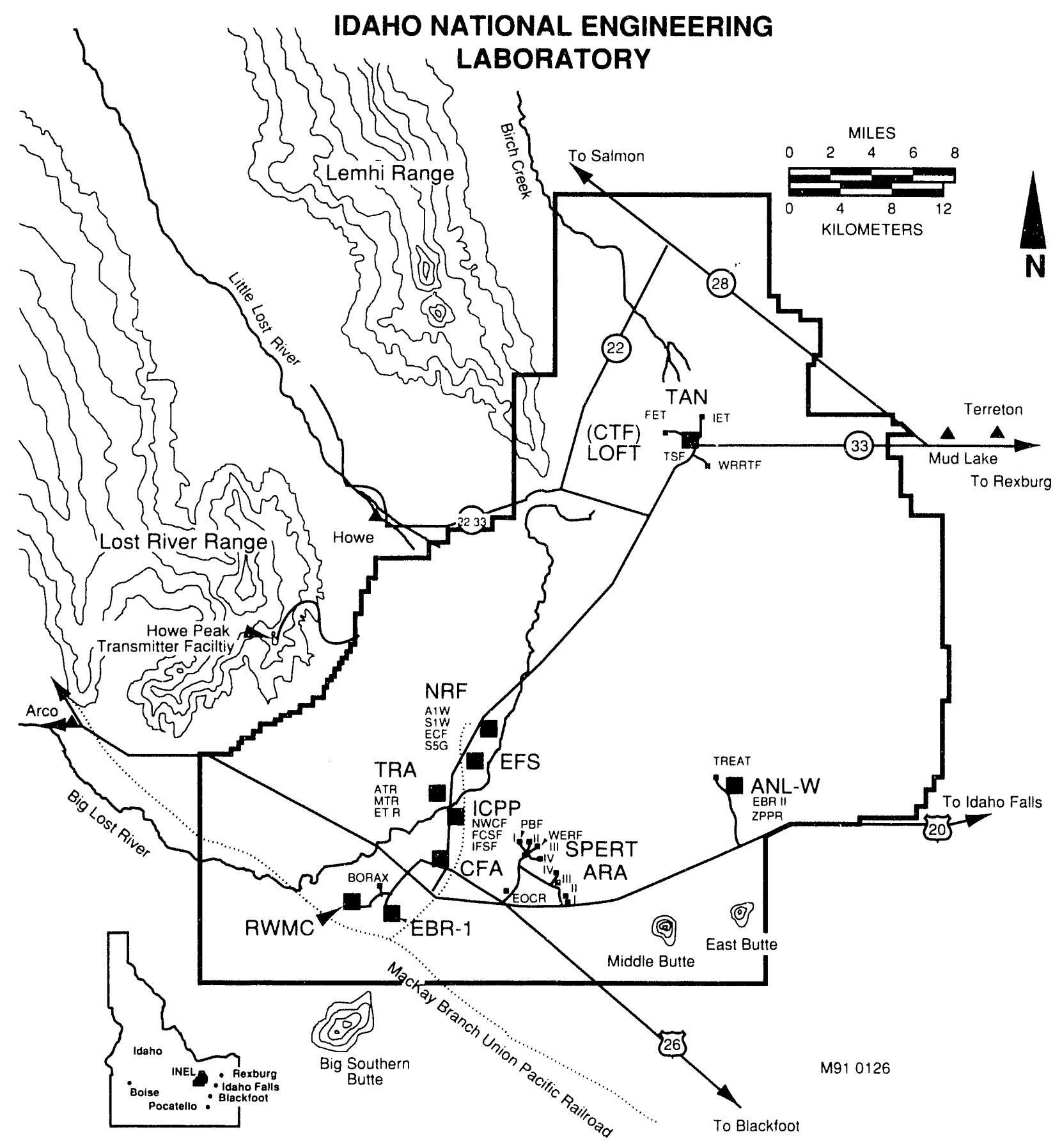

Figure A-1. INEL Site facility locations. 


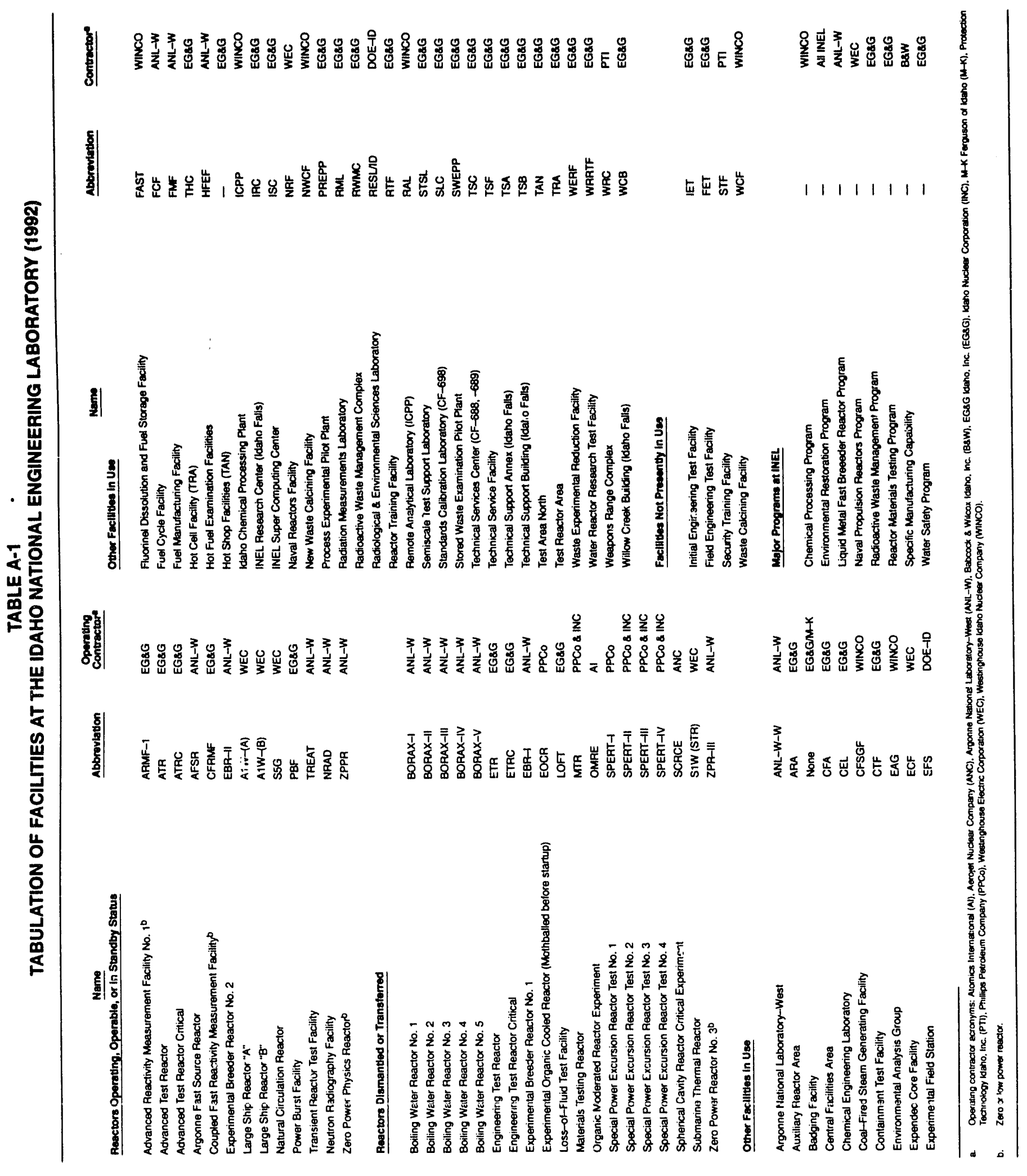


The surface of the plain is a combination of basaltic lava outcrops and alluvial sedimentary deposits. The sediments range from gravels and sands deposited by streams (as alluvial fans, channel fillings, and deltas) to silts and clays deposited in playas. The subsurface of the plain is principally composed of basalt flows interbedded with lacustrine and alluvial sedimentary deposits to a depth of about $760 \mathrm{~m}(2500 \mathrm{ft})$. The most recent volcanism, occurring about 2000 years ago, ${ }^{\mathrm{A}-2}$ is evident in the scenic basalt flows at Craters of the Moon National Monument, about $30 \mathrm{~km}(19 \mathrm{mi})$ to the southwest of the Site.

Annual precipitation in the Site area has averaged $22 \mathrm{~cm}$ ( $8.7 \mathrm{in}$.) over the past 15 years. Underlying the desert plain is a natural aquifer in the basaltic rock. Ground-water underflow from the Henry's Fork of the Snake River supplies a significant amount of water to the Snake River Plain aquifer below the INEL. Additional recharge to the aquifer comes from the Big and Little Lost Rivers and Birch Creek, which originate in the mountains to the northwest of the INEL, flow onto the Site during at least a few months of the year, and sink into its porous soils. The underground water moves laterally at an average rate of 1.5 to $6 \mathrm{~m} / \mathrm{d}(5$ to $20 \mathrm{ft} / \mathrm{d})$ to the south and west, emerging in springs along the Snake River between Milner and Bliss, Idaho. Discharge volumes from springs in this region are approximately $4.3 \times 10^{9} \mathrm{~m}^{3}\left(3.5 \times 10^{6}\right.$ acre- $\left.\mathrm{ft}\right)$ per year. Both the aquifer and surface waters of the Snake River Plain are used for crop irrigation.

Winds are predominantly along the SW-NE axis of the plain, with the most frequent and strongest winds from the SW. The NE winds are mostly nocturnal. Spring is the windiest time of the year, while winter has more calm periods and more nighttime temperature inversions.

\section{REFERENCES}

A-1 K. L. Clawson, G. E. Start, N. R. Ricks, Climatography of the Idaho National Engineering Laboratory, Second Edition, National Oceanic and Atmospheric Administration, Environmental Research Laboratory, Air Resources Laboratory, DOE/ID-12118, December 1989.

A-2 M.A. Kuntz, et al., "Holocene Basaltic Volcanism Along the Great Rift, Central and Eastern Snake River Plain, Idaho," Utah Geological and Mineral Survey Special Studies 61, 1983, Guidebook, Part-3, GSA Rocky Mountain and Cordilleran Sections Meeting: Salt Lake City, Utah, May 1983. 


\section{APPENDIX B \\ SUMMARY TABLES FROM THE INEL ENVIRONMENTAL SURVEILLANCE AND CONTRACTOR EFFLUENT MONITORING PROGRAMS}


B-2 


\section{APPENDIX B}

\section{SLMMARY TABLES FROM THE INEL ENVIRONMENTAL SURVEILLANCE AND CONTRACTOR EFFLUENT MONITORING PROGRAMS}

This appendix contains two figures (B-1 and B-2) and data summary tables (B-1 through B-24) for the RESL Environmental Surveillance Program and for contractor effluent and drinking water monitoring data at the INEL Site for 1992.

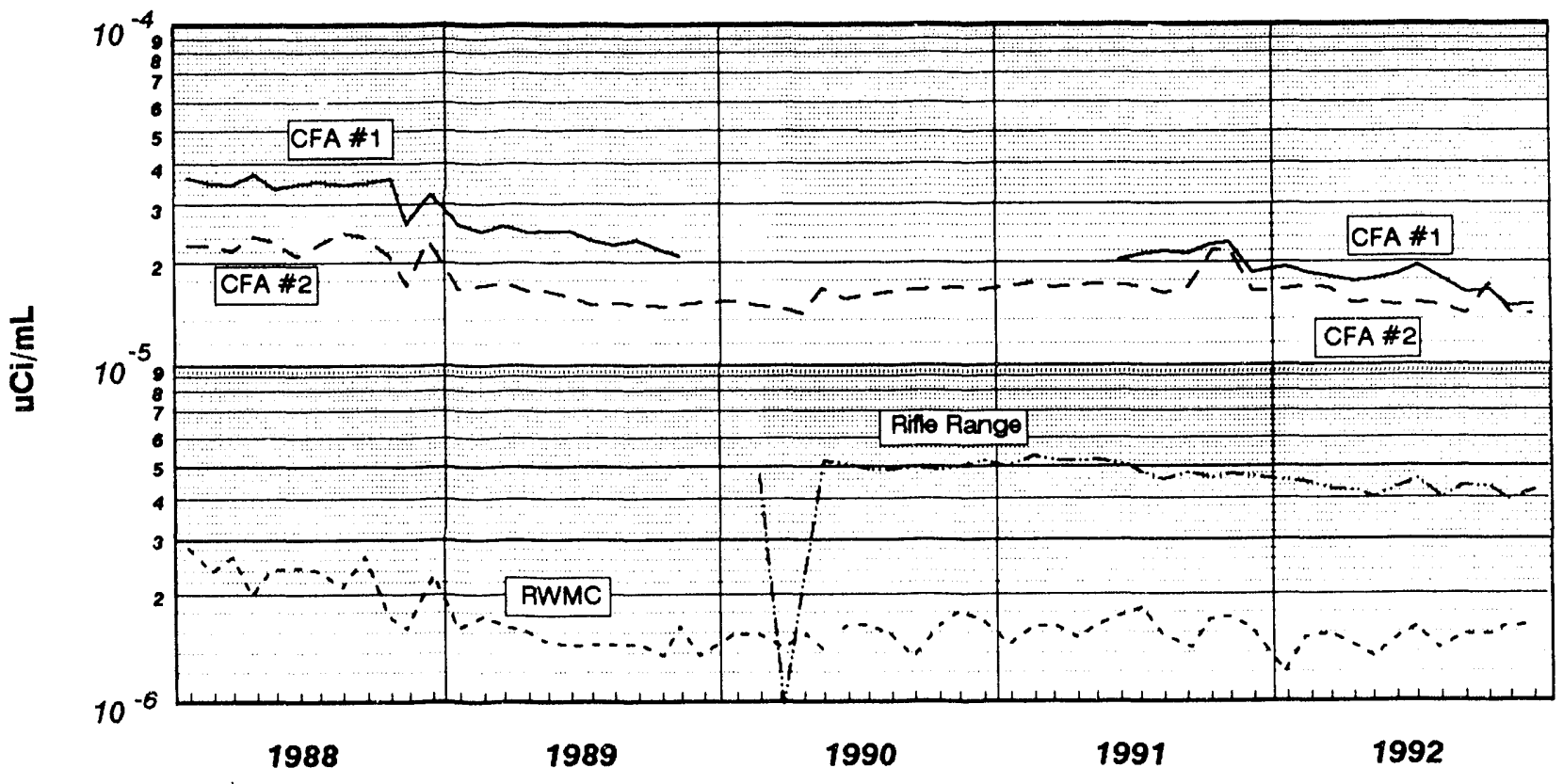

Figure B-1. Tritium concentrations in onsite drinking water wells, 1988-92. 

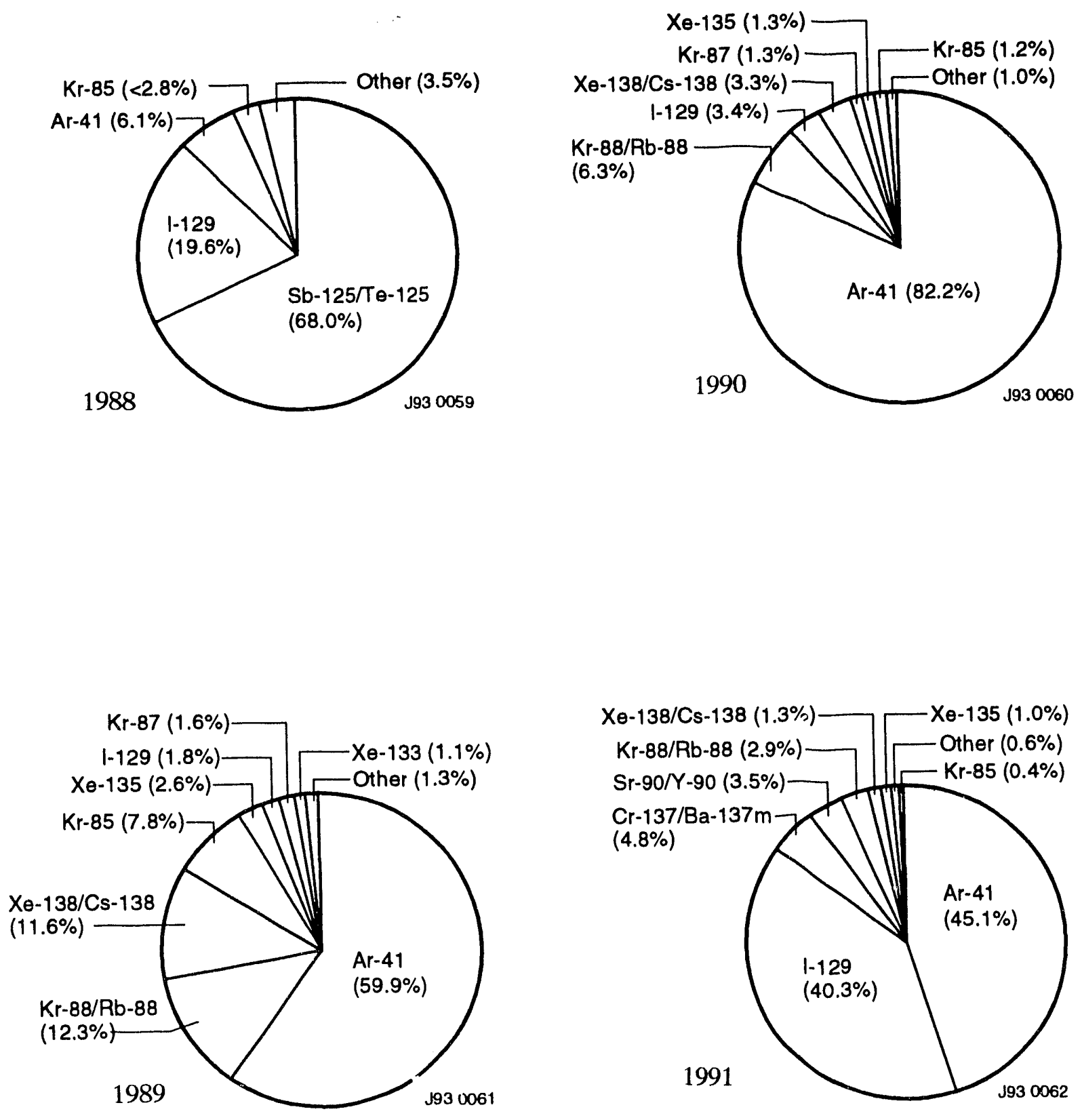

Figure B-2. Nuclides contributing to maximum individual doses in 1988-1991. 


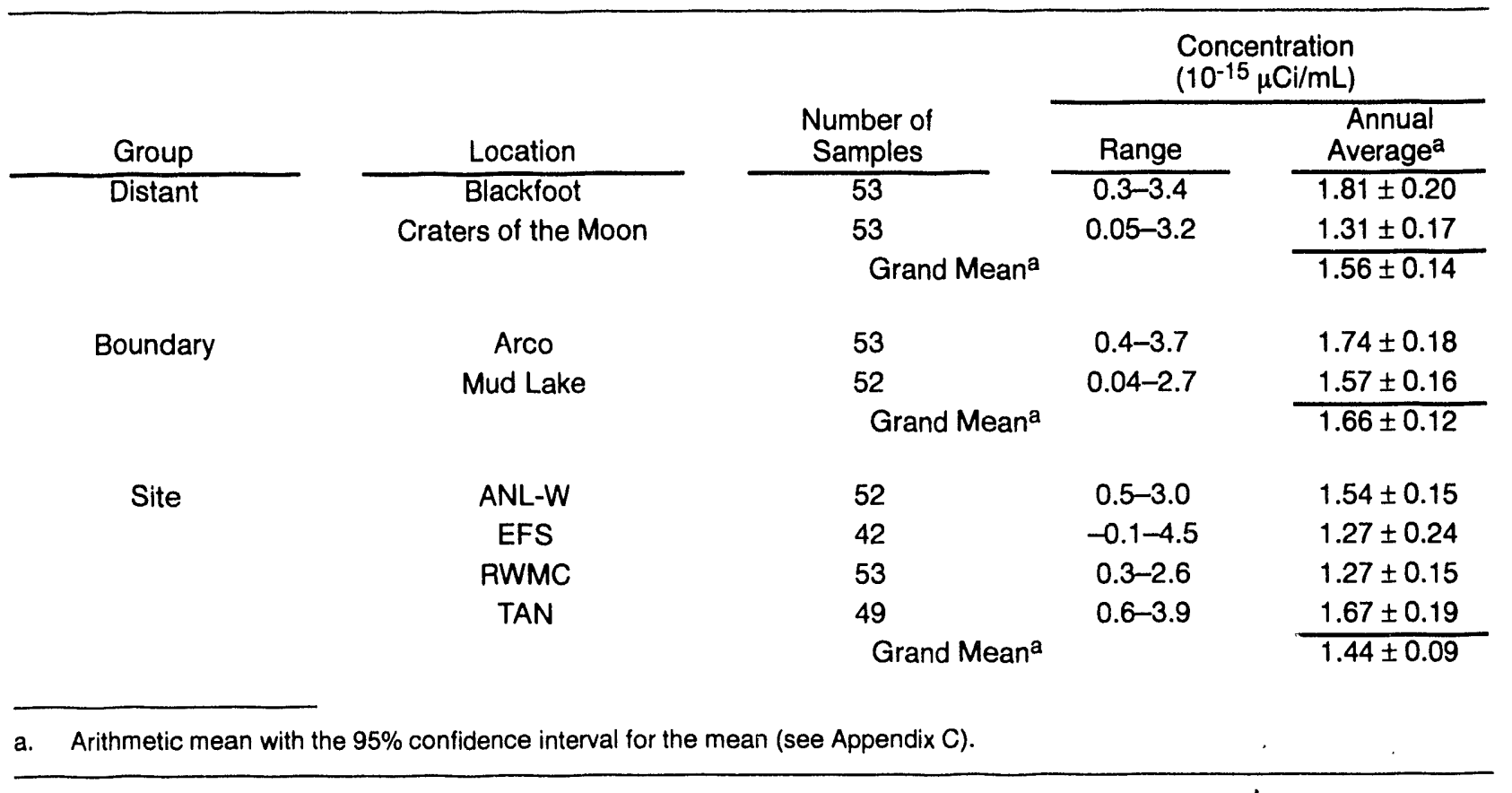




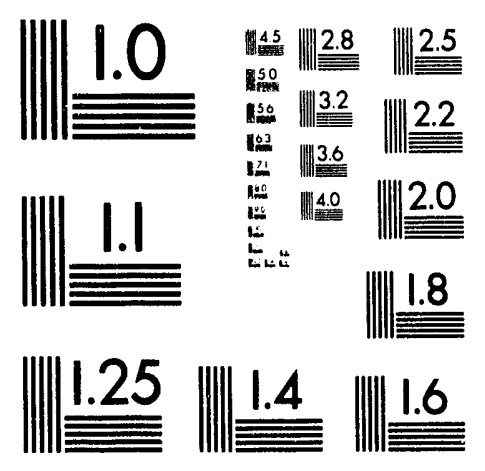



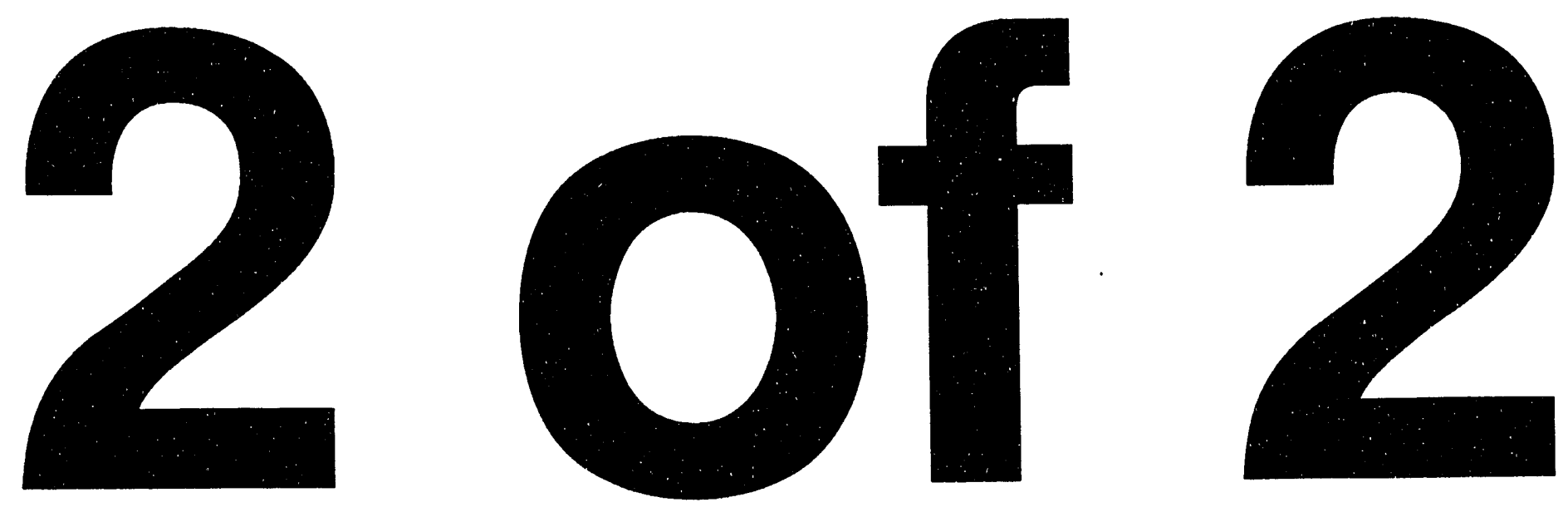
TABLE B-2

GROSS BETA ACTIVITY IN AIR (1992)

\begin{tabular}{|c|c|c|c|c|}
\hline \multirow[b]{2}{*}{ Group } & \multirow[b]{2}{*}{ Location } & \multicolumn{3}{|c|}{ Concentration $\left(10^{-15} \mu \mathrm{Ci} / \mathrm{mL}\right)$} \\
\hline & & $\begin{array}{l}\text { Number of } \\
\text { Samples }\end{array}$ & Range & $\begin{array}{c}\text { Annual } \\
\text { Average }^{\mathrm{a}}\end{array}$ \\
\hline \multirow[t]{5}{*}{ Distant } & Blackfoot & 53 & $9-49$ & $25 \pm 2$ \\
\hline & Craters of the Moon & 53 & $8-42$ & $23 \pm 2$ \\
\hline & Idaho Falls & 46 & $12-51$ & $27 \pm 3$ \\
\hline & Rexburg & 53 & $9-47$ & $24 \pm 2$ \\
\hline & Grand Meana & - & - & $25 \pm 1$ \\
\hline \multirow[t]{8}{*}{ Boundary } & Arco & 53 & $11-53$ & $25 \pm 2$ \\
\hline & Atomic City & 51 & $8-47$ & $25 \pm 2$ \\
\hline & FAA Tower & 52 & $12-47$ & $28 \pm 2$ \\
\hline & Howe & 51 & $10-53$ & $29 \pm 3$ \\
\hline & Monteview & 53 & $10-45$ & $23 \pm 2$ \\
\hline & Mud Lake & 52 & $11-62$ & $27 \pm 3$ \\
\hline & Reno Ranch & 51 & $11-41$ & $25 \pm 2$ \\
\hline & Grand Mean ${ }^{a}$ & - & - & $26 \pm 1$ \\
\hline \multirow[t]{13}{*}{ Site } & ANL-W & 52 & $10-54$ & $27 \pm 2$ \\
\hline & ARA & 53 & $11-48$ & $29 \pm 2$ \\
\hline & CFA & 53 & $12-56$ & $29 \pm 3$ \\
\hline & EBR-I & 53 & $9-51$ & $27 \pm 3$ \\
\hline & EFS & 42 & $4-56$ & $25 \pm 3$ \\
\hline & ICPP & 53 & $11-51$ & $27 \pm 3$ \\
\hline & NRF & 52 & $13-51$ & $27 \pm 3$ \\
\hline & PBF & 49 & $10-51$ & $27 \pm 3$ \\
\hline & RWMC & 53 & $9-43$ & $22 \pm 2$ \\
\hline & TAN & 49 & $12-56$ & $29 \pm 3$ \\
\hline & TRA & 52 & $11-50$ & $26 \pm 2$ \\
\hline & VANB & 53 & $11-60$ & $29 \pm 3$ \\
\hline & Grand Meana & - & - & $27 \pm 1$ \\
\hline
\end{tabular}

a. Arithmetic mean with the $95 \%$ confidence interval for the mean (see Appendix C.) 


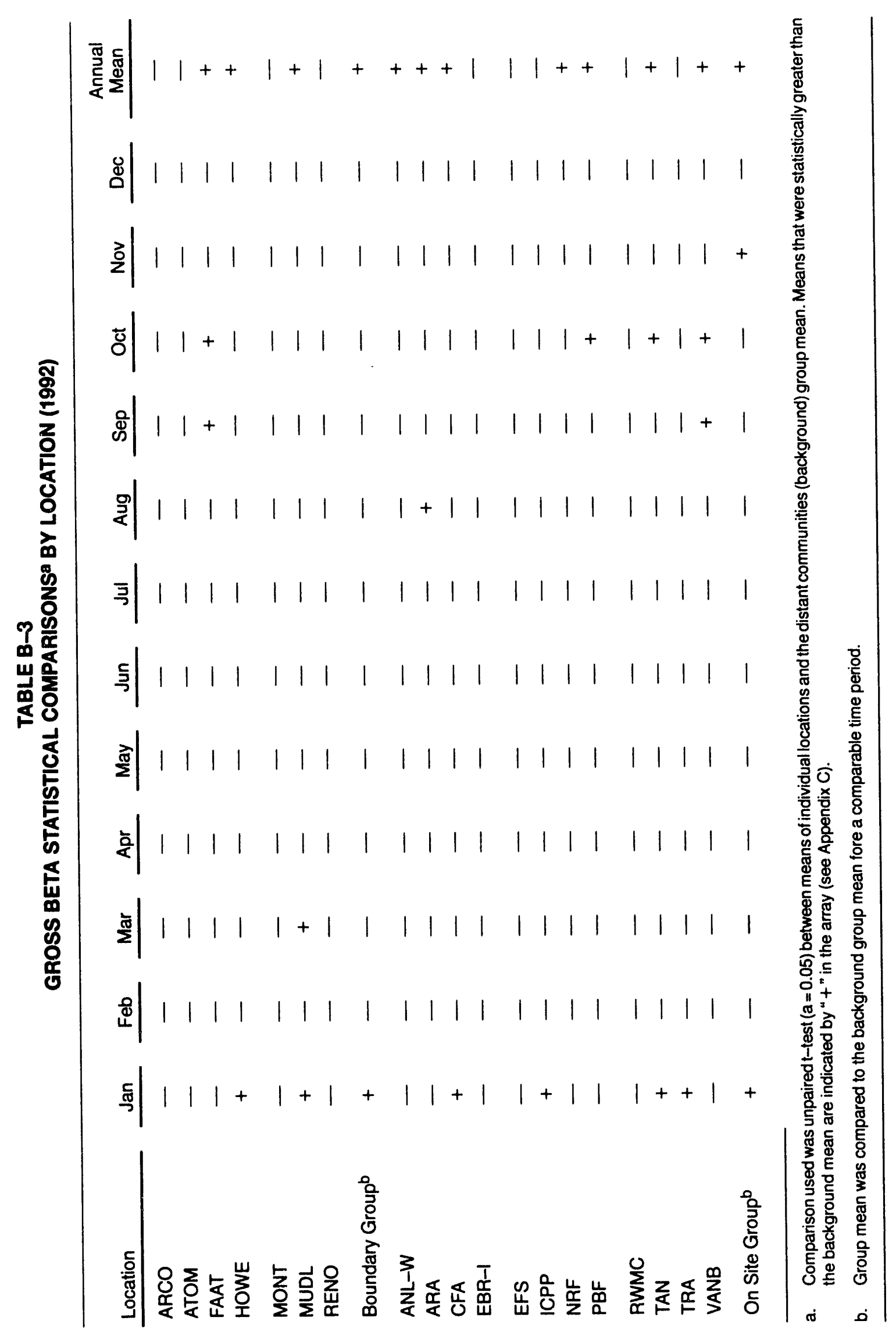

B-7 
TABLE B-4

SPECIFIC RADIONUCLIDE ACTIVITY IN AIR (1992)

\begin{tabular}{|c|c|c|c|c|c|c|}
\hline \multirow[b]{2}{*}{ Nuclide } & \multirow{2}{*}{$\begin{array}{c}\text { Composite } \\
\text { Group }^{\mathrm{a}}\end{array}$} & \multicolumn{5}{|c|}{ Concentration $\left(10^{-15} \mu \mathrm{Ci} / \mathrm{mL}\right)$} \\
\hline & & Minimum $^{b}$ & Maximumb & Meanc & DCG $^{d}$ & $\sim M D C^{e}$ \\
\hline $\mathrm{Ce}-141$ & $\begin{array}{l}\text { Distant } \\
\text { Boundary } \\
\text { Site }\end{array}$ & $\begin{array}{l}<M^{\prime} C^{f} \\
<M D C \\
<M D C\end{array}$ & $\begin{array}{l}<M D C \\
<M D C \\
\quad 5 \pm 4\end{array}$ & $\begin{array}{l}0.5 \pm 1.8 \\
1.2 \pm 0.7 \\
0.8 \pm 0.6\end{array}$ & $1,000,000$ & 2 \\
\hline $\mathrm{Ce}-144$ & $\begin{array}{l}\text { Distant } \\
\text { Boundary } \\
\text { Site }\end{array}$ & $\begin{array}{l}<M D C \\
<M D C \\
<M D C\end{array}$ & $\begin{array}{l}<M D C \\
<M D C \\
<M D C\end{array}$ & $\begin{array}{l}-1.0 \pm 0.9 \\
-1.3 \pm 0.9 \\
-0.5 \pm 0.5\end{array}$ & 400,000 & 1 \\
\hline Co-60 & $\begin{array}{l}\text { Distant } \\
\text { Boundary } \\
\text { Site }\end{array}$ & $\begin{array}{l}<M D C \\
<M D C \\
<M D C\end{array}$ & $\begin{array}{l}<M D C \\
<M D C \\
<M D C\end{array}$ & $\begin{array}{l}0.02 \pm 0.14 \\
0.02 \pm 0.11 \\
0.07 \pm 0.09\end{array}$ & 9,000 & 0.1 \\
\hline Cs-134 & $\begin{array}{l}\text { Distant } \\
\text { Boundary } \\
\text { Site }\end{array}$ & $\begin{array}{l}<M D C \\
<M D C \\
<M D C\end{array}$ & $\begin{array}{l}<M D C \\
<M D C \\
<M D C\end{array}$ & $\begin{aligned} 0.03 & \pm 0.17 \\
-0.01 & \pm 0.7 \\
0.07 & \pm 0.06\end{aligned}$ & 20,000 & 6 \\
\hline Cs-137 & $\begin{array}{l}\text { Distant } \\
\text { Boundary } \\
\text { Site }\end{array}$ & $\begin{array}{l}<M D C \\
<M D C \\
<M D C\end{array}$ & $\begin{array}{l}<M D C \\
<M D C \\
<M D C\end{array}$ & $\begin{array}{l}0.16 \pm 0.17 \\
0.17 \pm 0.12 \\
0.09 \pm 0.10\end{array}$ & $1,000,000$ & 2 \\
\hline$M n-54$ & $\begin{array}{l}\text { Distant } \\
\text { Boundary } \\
\text { Site }\end{array}$ & $\begin{array}{l}<M D C \\
<M D C \\
<M D C\end{array}$ & $\begin{array}{l}<M D C \\
<M D C \\
<M D C\end{array}$ & $\begin{aligned}-0.01 & \pm 0.13 \\
0.12 & \pm 0.09 \\
-0.007 & \pm 0.10\end{aligned}$ & 400,000 & 1 \\
\hline$R u-103$ & $\begin{array}{l}\text { Distant } \\
\text { Boundary } \\
\text { Site }\end{array}$ & $\begin{array}{l}<M D C \\
<M D C \\
<M D C\end{array}$ & $\begin{array}{l}<M D C \\
<M D C \\
<M D C\end{array}$ & $\begin{array}{r}0.09 \pm 0.5 \\
0.04 \pm 0.4 \\
-0.06 \pm 0.3\end{array}$ & 9,000 & 0.1 \\
\hline$R u-106$ & $\begin{array}{l}\text { Distant } \\
\text { Boundary } \\
\text { Site }\end{array}$ & $\begin{array}{l}<M D C \\
<M D C \\
<M D C\end{array}$ & $\begin{array}{l}<M D C \\
<M D C \\
<M D C\end{array}$ & $\begin{array}{l}-1.2 \pm 1.3 \\
-1.8 \pm 1.3 \\
-1.4 \pm 1.0\end{array}$ & 20,000 & 6 \\
\hline $\mathrm{Sb}-125$ & $\begin{array}{l}\text { Distant } \\
\text { Boundary } \\
\text { Site }\end{array}$ & $\begin{array}{l}<M D C \\
<M D C \\
<M D C\end{array}$ & $\begin{array}{l}<M D C \\
<M D C \\
<M D C\end{array}$ & $\begin{array}{l}0.2 \pm 0.4 \\
0.0 \pm 0.4 \\
0.0 \pm 0.2\end{array}$ & 9,000 & 0.1 \\
\hline $\mathrm{Zr}-95$ & $\begin{array}{l}\text { Distant } \\
\text { Boundary } \\
\text { Site }\end{array}$ & $\begin{array}{l}<M D C \\
<M D C \\
<M D C\end{array}$ & $\begin{array}{l}<M D C \\
<M D C \\
<M D C\end{array}$ & $\begin{array}{l}-0.6 \pm 0.7 \\
-0.4 \pm 0.6 \\
-0.3 \pm 0.3\end{array}$ & 20,000 & 6 \\
\hline \multirow[t]{2}{*}{ Sr-90 } & $\begin{array}{l}\text { Distant } \\
\text { Boundary } \\
\text { Site }\end{array}$ & $\begin{array}{l}<M D C \\
<M D C \\
<M D C\end{array}$ & $\begin{array}{l}0.37 \pm 0.16 \\
0.22 \pm 0.14 \\
0.24 \pm 0.14\end{array}$ & $\begin{array}{l}0.13 \pm 0.11 \\
0.03 \pm 0.07 \\
0.07 \pm 0.11\end{array}$ & 9,000 & 0.1 \\
\hline & & \multicolumn{5}{|c|}{ Concentration $\left(10^{-18} \mu \mathrm{Ci} / \mathrm{mL}\right)$} \\
\hline$A m-241$ & $\begin{array}{l}\text { Distant } \\
\text { Boundary } \\
\text { Site }\end{array}$ & $\begin{array}{l}<M D C \\
<M D C \\
<M D C\end{array}$ & $\begin{array}{r}<M D C \\
<M D C \\
6 \pm 4\end{array}$ & $\begin{aligned} 4 & \pm 8 \\
0.0 & \pm 1.8 \\
1.0 & \pm 1.5\end{aligned}$ & 20,000 & 6 \\
\hline $\mathrm{Pu}-238$ & $\begin{array}{l}\text { Distant } \\
\text { Boundary } \\
\text { Site }\end{array}$ & $\begin{array}{l}<M D C \\
<M D C \\
<M D C\end{array}$ & $\begin{array}{r}3 \pm 2 \\
<M D C \\
<M D C\end{array}$ & $\begin{array}{r}0.5 \pm 1.4 \\
-0.3 \pm 0.9 \\
0.2 \pm 0.5\end{array}$ & 20,000 & 6 \\
\hline Pu-239/240 & $\begin{array}{l}\text { Distant } \\
\text { Boundary } \\
\text { Site }\end{array}$ & $\begin{array}{l}<M D C \\
<M D C \\
<M D C\end{array}$ & $\begin{array}{r}3 \pm 2 \\
<M D C \\
6 \pm 3\end{array}$ & $\begin{array}{l}1.6 \pm 1.1 \\
1.6 \pm 1.4 \\
1.3 \pm 0.9\end{array}$ & 20,000 & 6 \\
\hline
\end{tabular}

a. Sampling stations are shown in Figure 4 of this report.
b. Single quarterly composite sample analytical results $\pm 2 s$, decay corrected assuming a constant concentration and buildup during the sampling period (see Appendix C).

c. Arithmetic mean with the $95 \%$ confidence interval for the mean (see Appendix C).

d. Annual DCG given in Reference 2.

e. The MDC are approximate and are calculated for typical values for airflow volume, counting time, radionuclide composition of the sample, and time elapsed between collection and analysis. These values may vary slightly for actual samples.

f. Below MDC. 


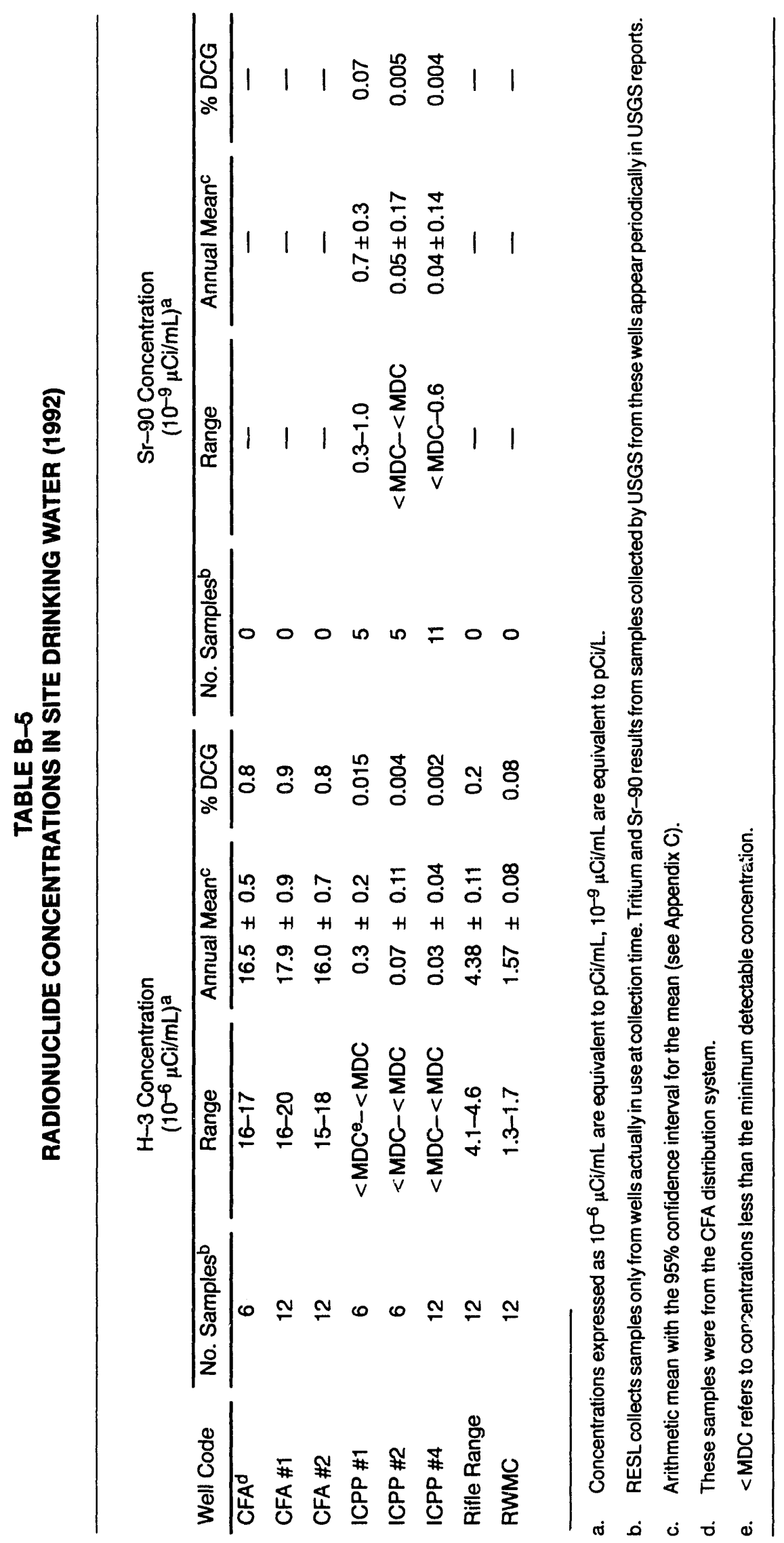


TABLE B-6

STRONTIUM-90 CONCENTRATIONS IN GARDEN LETTUCE (1988-1992)

\begin{tabular}{|c|c|c|c|c|c|c|}
\hline \multirow{2}{*}{\multicolumn{2}{|c|}{ Sample Location }} & \multicolumn{5}{|c|}{$\begin{array}{c}\text { Concentrations } \\
\text { ( } 10^{-9} \mu \mathrm{Ci} / \mathrm{g} \text { dry weight) }\end{array}$} \\
\hline & & 1988 & 1989 & 1990 & 1991 & 1992 \\
\hline \multicolumn{7}{|c|}{ Distant Group: } \\
\hline & Blackfoot & $140 \pm 60$ & $170 \pm 60$ & $150 \pm 60$ & $170 \pm 80$ & - $^{b}$ \\
\hline & Carey & $220 \pm 80$ & $140 \pm 60$ & $180 \pm 40$ & $210 \pm 80$ & $200 \pm 40$ \\
\hline & Idaho Falls & $<M M^{c} C^{C}$ & $<M D C$ & $-b$ & $170 \pm 100$ & $230 \pm 40$ \\
\hline & Pocatello & $160 \pm 60$ & $130 \pm 40$ & $210 \pm 60$ & $190 \pm 40$ & $80 \pm 40$ \\
\hline & Meand & $140 \pm 20$ & $125 \pm 75$ & $180 \pm 70$ & $190 \pm 30$ & $170 \pm 200^{8}$ \\
\hline \multicolumn{7}{|c|}{ Boundary Group: } \\
\hline & Arco & $80 \pm 60$ & $110 \pm 60$ & $50 \pm 40$ & $80 \pm 40$ & $50 \pm 40$ \\
\hline & Atomic City & $N S^{f}$ & $210 \pm 80$ & $140 \pm 40$ & $310 \pm 120$ & $210 \pm 60$ \\
\hline & Howe & $70 \pm 60$ & $60 \pm 40$ & $50 \pm 40$ & $50 \pm 40$ & $80 \pm 40$ \\
\hline & Mud Lake/Terreton & $190 \pm 80$ & $160 \pm 60$ & $90 \pm 60$ & $170 \pm 80$ & $150 \pm 40$ \\
\hline & Meand & $110 \pm 110^{\theta}$ & $135 \pm 105$ & $80 \pm 70$ & $150 \pm 160^{8}$ & $120 \pm 110$ \\
\hline a. & \multicolumn{6}{|c|}{ Analytical results $\pm 2 s$ (see Appendix $C$ ) } \\
\hline b. & \multicolumn{6}{|c|}{ Sample lost in preparation or analysis. } \\
\hline c. & \multicolumn{6}{|c|}{ Below the approximate $\mathrm{MDC}$ of $80 \times 10^{-9} \mu \mathrm{Ci} / \mathrm{g}$ dry weight. } \\
\hline d. & \multicolumn{6}{|c|}{ Arithmetic mean with the $95 \%$ confidence interval for the mean (see Appendix C). } \\
\hline e. & \multicolumn{6}{|c|}{ Mean is not statistically significant, or zero is contained within the $95 \%$ confidence interval. } \\
\hline f. & \multicolumn{6}{|c|}{ No sample was collected at this location during the year. } \\
\hline
\end{tabular}


TABLE B-7

STRONTIUM-90 CONCENTRATIONS IN WHEAT (1988-1992)

\begin{tabular}{|c|c|c|c|c|c|}
\hline \multirow{2}{*}{ Sample Location } & \multicolumn{5}{|c|}{$\begin{array}{c}\text { Concentrations } a \\
\left(10^{-9} \mu \mathrm{Ci} / \mathrm{g} \text { dry weight) }\right.\end{array}$} \\
\hline & 1988 & 1989 & 1990 & 1991 & 1992 \\
\hline \multicolumn{6}{|l|}{ Distant Group: } \\
\hline American Falls & $15 \pm 4$ & $3 \pm 2$ & $10 \pm 3$ & $10 \pm 4$ & $11 \pm 2$ \\
\hline Blackfoot & $11 \pm 4$ & $9 \pm 3$ & $21 \pm 4$ & $10 \pm 3$ & $7 \pm 2$ \\
\hline Carey & $6 \pm 3$ & $N^{b}$ & NS & NS & $10 \pm 2$ \\
\hline Dietrich & $5 \pm 3$ & $7 \pm 3$ & $9 \pm 3$ & $6 \pm 3$ & NS \\
\hline Idaho Falls & $7 \pm 3$ & $11 \pm 3$ & $13 \pm 4$ & $9 \pm 3$ & $9 \pm 2$ \\
\hline Minidoka & $6 \pm 4$ & $8 \pm 3$ & $12 \pm 4$ & $8 \pm 4$ & $7 \pm 2$ \\
\hline Meanc & $8 \pm 4$ & $8 \pm 4$ & $13 \pm 6$ & $8 \pm 2$ & $9 \pm 2$ \\
\hline \multicolumn{6}{|l|}{ Boundary Group: } \\
\hline Arco & $4 \pm 3$ & $5 \pm 3$ & $13 \pm 4$ & $10 \pm 3$ & $10 \pm 2$ \\
\hline Monteview & $4 \pm 3$ & $6 \pm 2$ & $9 \pm 3$ & $3 \pm 3$ & $9 \pm 2$ \\
\hline Mud Lake & $5 \pm 3$ & $12 \pm 3$ & $7 \pm 3$ & $9 \pm 3$ & $4 \pm 2$ \\
\hline Taber & NS & $8 \pm 3$ & $10 \pm 3$ & $15 \pm 4$ & $8 \pm 2$ \\
\hline Terreton & $8 \pm 4$ & $5 \pm 2$ & $12 \pm 3$ & $5 \pm 3$ & $3 \pm 2$ \\
\hline Meanc & $5 \pm 2$ & $7 \pm 4$ & $10 \pm 3$ & $8 \pm 6$ & $7 \pm 4$ \\
\hline \multicolumn{6}{|c|}{$\begin{array}{l}\text { a. Analytical results } \pm 2 \mathrm{~s} \text { (see Appenbdix C). Approximate } \mathrm{MDC} \text { of } \mathrm{Sr}-90 \text { in wheat is } \\
\text { b. No sample was collected at this location during the year. } \\
\text { c. Arithmetic mean with the } 95 \% \text { confidence interval for the mean (see Appendix C). }\end{array}$} \\
\hline
\end{tabular}


TABLE B-8

RADIONUCLIDES IN OFFSITE SURFACE SOILSa (1992)

\begin{tabular}{|c|c|c|c|c|c|c|c|c|}
\hline \multirow[b]{2}{*}{ Nuclide } & \multirow[b]{2}{*}{ Yeard } & \multicolumn{4}{|c|}{$\begin{array}{l}\text { Geometric Mean with } \\
\text { 95\% Confidence Intervalb }\end{array}$} & \multirow{2}{*}{$\begin{array}{l}\text { Number of } \\
\text { Samples }\end{array}$} & \multicolumn{2}{|c|}{$-M D C C$} \\
\hline & & & $\mathrm{i} / \mathrm{g}$ & & & & $\mathrm{pCi} / \mathrm{g}$ & $\mathrm{nCi} / \mathrm{m}^{2}$ \\
\hline \multirow[t]{9}{*}{ Cs-137 } & $1970-75$ & 0.94 & $(0.78-1.1)$ & 54 & $(49-59)$ & 60 & 0.01 & 1 \\
\hline & 1978 & 0.94 & $(0.72-1.2)$ & 58 & $(44-75)$ & 10 & 0.01 & 1 \\
\hline & 1980 & 0.64 & $(0.46-0.90)$ & 41 & $(29-57)$ & 10 & 0.01 & 1 \\
\hline & 1982 & 0.90 & $(0.64-1.2)$ & 44 & $(31-62)$ & 10 & 0.01 & 1 \\
\hline & 1984 & 0.69 & $(0.49-0.97)$ & 43 & $(31-60)$ & 7 & 0.01 & 1 \\
\hline & 1986 & 0.81 & $(0.54-1.2)$ & 48 & $(34-67)$ & 13 & 0.01 & 1 \\
\hline & 1988 & 0.66 & $(0.34-1.3)$ & 47 & $(46-48)$ & 12 & 0.01 & 1 \\
\hline & 1990 & 0.73 & $(0.54-0.99)$ & 43 & $(33-56)$ & 12 & 0.01 & 1 \\
\hline & 1992 & 0.78 & $(0.56-1.09)$ & 42 & $(31-57)$ & 12 & 0.01 & 1 \\
\hline \multirow[t]{9}{*}{$\mathrm{Sr}-90$} & $1970-75$ & 0.54 & $(0.43-0.59)$ & 34 & $(31-37)$ & 55 & 0.09 & 10 \\
\hline & 1978 & 0.52 & $(0.40-0.68)$ & 32 & $(23-45)$ & 10 & 0.09 & 10 \\
\hline & 1980 & 0.35 & $(0.25-0.49)$ & 22 & $(15-33)$ & 10 & 0.09 & 10 \\
\hline & 1982 & 0.37 & $(0.26-0.52)$ & 18 & $(11-29)$ & 10 & 0.09 & 10 \\
\hline & 1984 & 0.45 & $(0.32-0.63)$ & 28 & $(20-39)$ & 7 & 0.09 & 10 \\
\hline & 1986 & 0.52 & $(0.43-0.62)$ & 30 & $(25-37)$ & 13 & 0.09 & 10 \\
\hline & 1988 & 0.38 & $(0.28-0.53)$ & 23 & $(17-31)$ & 12 & 0.09 & 10 \\
\hline & 1990 & 0.30 & $(0.22-0.40)$ & 17 & $(13-23)$ & 12 & 0.09 & 10 \\
\hline & 1992 & $N A^{*}$ & - & 一 & - & - & - & - \\
\hline \multirow[t]{9}{*}{$P u-238$} & $1970-75$ & 0.0028 & $(0.0023-0.0034)$ & 0.15 & $(0.13-0.18)$ & 55 & 0.002 & 0.1 \\
\hline & 1978 & 0.0010 & $(0.0005-0.0020)$ & 0.06 & $(0.03-0.11)$ & 10 & 0.002 & 0.1 \\
\hline & 1980 & 0.0007 & $(0.0005-0.0009)$ & 0.05 & $(0.04-0.07)$ & 10 & 0.002 & 0.1 \\
\hline & 1982 & 0.0011 & $(0.0007-0.0017)$ & 0.05 & $(0.03-0.08)$ & 10 & 0.002 & 0.1 \\
\hline & 1984 & 0.0015 & $(0.0008-0.0027)$ & 0.08 & $(0.04-0.15)$ & 7 & 0.002 & 0.1 \\
\hline & 1986 & 0.0021 & $(0.0010-0.0046)$ & 0.12 & $(0.06-0.27)$ & 13 & 0.002 & 0.1 \\
\hline & 1988 & 0.0014 & $(0.0009-0.0024)$ & 0.09 & $(0.05-0.14)$ & 12 & 0.002 & 0.1 \\
\hline & 1990 & 0.0006 & $(0.0003-0.0012)$ & 0.04 & $(0.02-0.09)$ & 12 & 0.002 & 0.1 \\
\hline & 1992 & 0.0013 & $(0.0009-0.0019)$ & 0.07 & $(0.05-0.10)$ & $1 ?$ & 0.002 & 0.1 \\
\hline \multirow[t]{9}{*}{ Pu-239/240 } & $1970-75$ & 0.020 & $(0.017-0.024)$ & 1.06 & $(0.96-1.17)$ & 54 & 0.002 & 0.1 \\
\hline & 1978 & 0.018 & $(0.013-0.025)$ & 1.09 & $(0.78-1.53)$ & 10 & 0.002 & 0.1 \\
\hline & 1980 & 0.010 & $(0.006-0.017)$ & 0.63 & $(0.37-1.07)$ & 10 & 0.002 & 0.1 \\
\hline & 1982 & 0.022 & $(0.016-0.031)$ & 1.06 & $(0.76-1.48)$ & 10 & 0.002 & 0.1 \\
\hline & 1984 & 0.016 & $(0.011-0.022)$ & 1.02 & $(0.73-1.43)$ & 7 & 0.002 & 0.1 \\
\hline & 1986 & 0.018 & $(0.012-0.027)$ & 1.05 & $(0.70-1.58)$ & 13 & 0.002 & 0.1 \\
\hline & 1988 & 0.021 & $(0.015-0.029)$ & 1.22 & $(0.91-1.65)$ & 12 & 0.002 & 0.1 \\
\hline & 1990 & 0.024 & $(0.017-0.035)$ & 1.43 & $(1.01-2.03)$ & 12 & 0.002 & 0.1 \\
\hline & 1992 & 0.021 & $(0.013-0.033)$ & 1.52 & $(0.74-1.70)$ & 12 & 0.002 & 0.1 \\
\hline \multirow[t]{9}{*}{ Am-241 } & $1970-75$ & 0.004 & $(0.003-0.005)$ & 0.24 & $(0.20-0.29)$ & 37 & 0.003 & 0.2 \\
\hline & 1978 & 0.006 & $(0.004-0.009)$ & 0.38 & $(0.29-0.49)$ & 10 & 0.003 & 0.2 \\
\hline & 1980 & 0.003 & $(0.002-0.004)$ & 0.20 & $(0.14-0.28)$ & 10 & 0.003 & 0.2 \\
\hline & 1982 & 0.004 & $(0.003-0.006)$ & 0.21 & $(0.13-0.34)$ & 10 & 0.003 & 0.2 \\
\hline & 1984 & 0.004 & $(0.002-0.007)$ & 0.26 & $(0.15-0.44)$ & 7 & 0.003 & 0.2 \\
\hline & 1986 & 0.004 & $(0.002-0.007)$ & 0.23 & $(0.13-0.41)$ & 13 & 0.003 & 0.2 \\
\hline & 1988 & 0.005 & $(0.004-0.008)$ & 0.31 & $(0.22-0.45)$ & 12 & 0.003 & 0.2 \\
\hline & 1990 & 0.005 & $(0.003-0.008)$ & 0.27 & $(0.16-0.45)$ & 12 & 0.003 & 0.2 \\
\hline & 1992 & 0.004 & $(0.002-0.006)$ & 0.19 & $(0.12-0.31)$ & 12 & 0.003 & 0.2 \\
\hline suriace & collected & th of $5 \mathrm{~cm}$. & & & & & & \\
\hline Geomerric & vith the $95 \% \mathrm{c}$ & nce interval & mean (see Appendix C & & & & & \\
\hline Approxima & imum detectab & centration. & & & & & & \\
\hline d. Excluding & which no san & vere taken. & & & & & & \\
\hline e. Analytica & Sr-90 wer & railable at 0 & blication of this repo & & & & & \\
\hline
\end{tabular}


TABLE B-9

ENVIRONMENTAL RADIATION EXPOSURES (1988-1992)

\begin{tabular}{|c|c|c|c|c|c|}
\hline \multirow[b]{2}{*}{ Location } & \multicolumn{5}{|c|}{$\begin{array}{c}\text { Annual Exposure } \\
(\mathrm{mR})^{\mathrm{a}}\end{array}$} \\
\hline & 1988 & 1989 & 1990 & 1991 & 1992 \\
\hline \multicolumn{6}{|l|}{ Distant Group: } \\
\hline Aberdeen & $108 \pm 4$ & $114 \pm 6$ & $114 \pm 4$ & $126 \pm 5$ & $-^{b}$ \\
\hline Blackfoot & $112 \pm 5$ & $117 \pm 8$ & $118 \pm 5$ & $122 \pm 6$ & $122 \pm 4$ \\
\hline Craters of the Moon & $118 \pm 4$ & $123 \pm 7$ & $116 \pm 4$ & $131 \pm 10$ & $132 \pm 6$ \\
\hline Idaho Falls & $113 \pm 4$ & $-c$ & $126 \pm 4$ & $127 \pm 6$ & $138 \pm 9$ \\
\hline Minidoka & $92 \pm 3$ & $108 \pm 6$ & $99 \pm 4$ & $103 \pm 4$ & $129 \pm 6$ \\
\hline Rexburg & $114 \pm 4$ & $114 \pm 5$ & $110 \pm 4$ & $113 \pm 5$ & $109 \pm 4$ \\
\hline Roberts & $122 \pm 6$ & $127 \pm 6$ & $125 \pm 5$ & $137 \pm 8$ & $136 \pm 6$ \\
\hline Meand & $111 \pm 9$ & $117 \pm 7$ & $115 \pm 9$ & $123 \pm 11$ & $128 \pm 11$ \\
\hline \multicolumn{6}{|l|}{ Boundary Group: } \\
\hline Arco & $106 \pm 6$ & $117 \pm 5$ & $114 \pm 4$ & $123 \pm 9$ & $134 \pm 6$ \\
\hline Atomic City & $118 \pm 7$ & $125 \pm 6$ & $121 \pm 4$ & $117 \pm 9$ & $132 \pm 5$ \\
\hline Howe & $105^{\prime} \pm 6$ & $117 \pm 6$ & - & $114 \pm 8$ & $126 \pm 4$ \\
\hline Monteview & $101 \pm 5$ & $120 \pm 6$ & $110 \pm 4$ & $128 \pm 4$ & $120 \pm 5$ \\
\hline Mud Lake & $111 \pm 5$ & $125 \pm 6$ & $121 \pm 6$ & $124 \pm 6$ & $138 \pm 4$ \\
\hline Reno Fianch & $110 \pm 4$ & $105 \pm 6$ & $110 \pm 4$ & $120 \pm 8$ & $112 \pm 4$ \\
\hline Meand & $109 \pm 6$ & $118 \pm 8$ & $115 \pm 7$ & $121 \pm 5$ & $127 \pm 10$ \\
\hline \multicolumn{6}{|c|}{ a. Annual exposure \pm 2 s (see Appendix $C$ ). } \\
\hline \multicolumn{6}{|c|}{ Dosimeter missing at November 1992 collection time. } \\
\hline \multicolumn{6}{|c|}{ c. Dosimeter missing at November 1989 collection time. } \\
\hline \multicolumn{6}{|c|}{ d. Arithmetic mean with the $95 \%$ confidence interval for the mean (see Appendix $\mathrm{C}$ ). } \\
\hline e. Dosimeter missing at $\mathrm{N}$ & 1990 collec & & & & \\
\hline
\end{tabular}




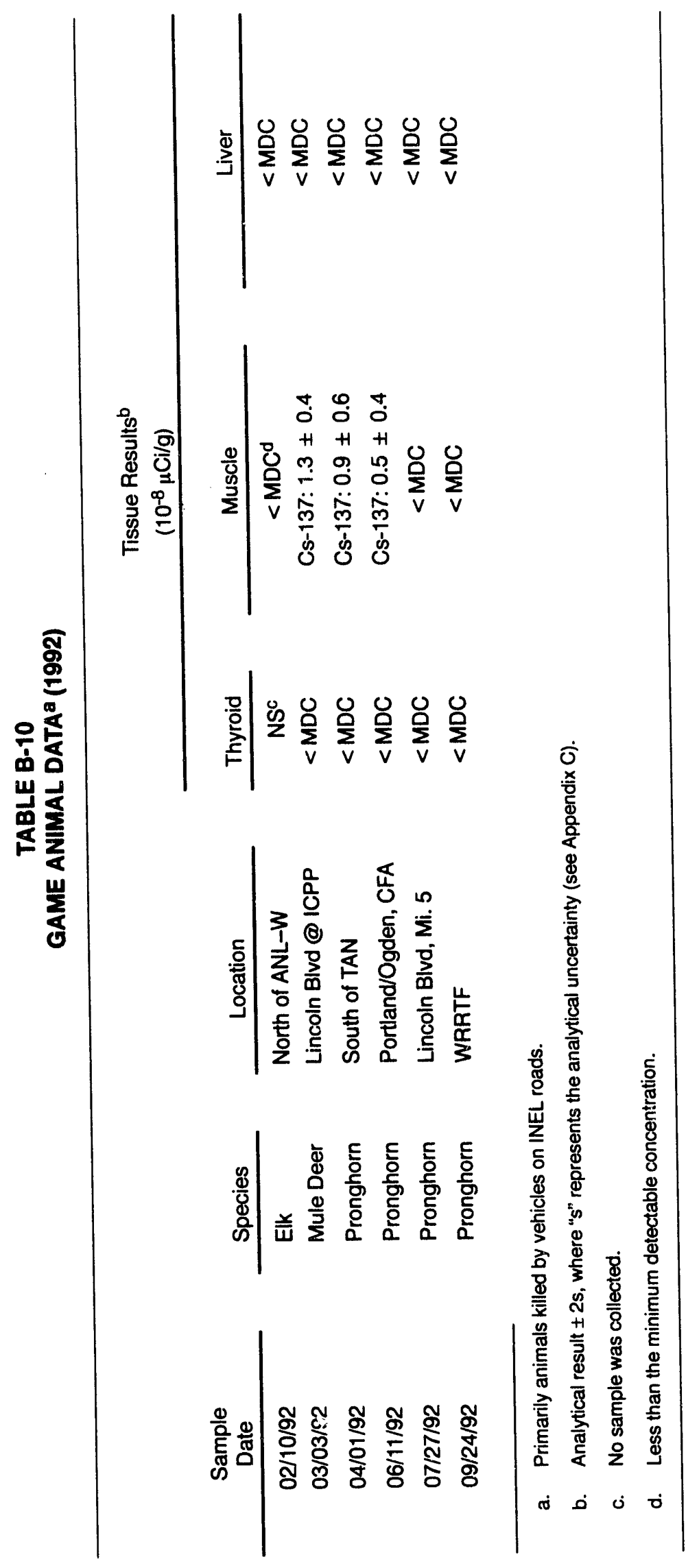




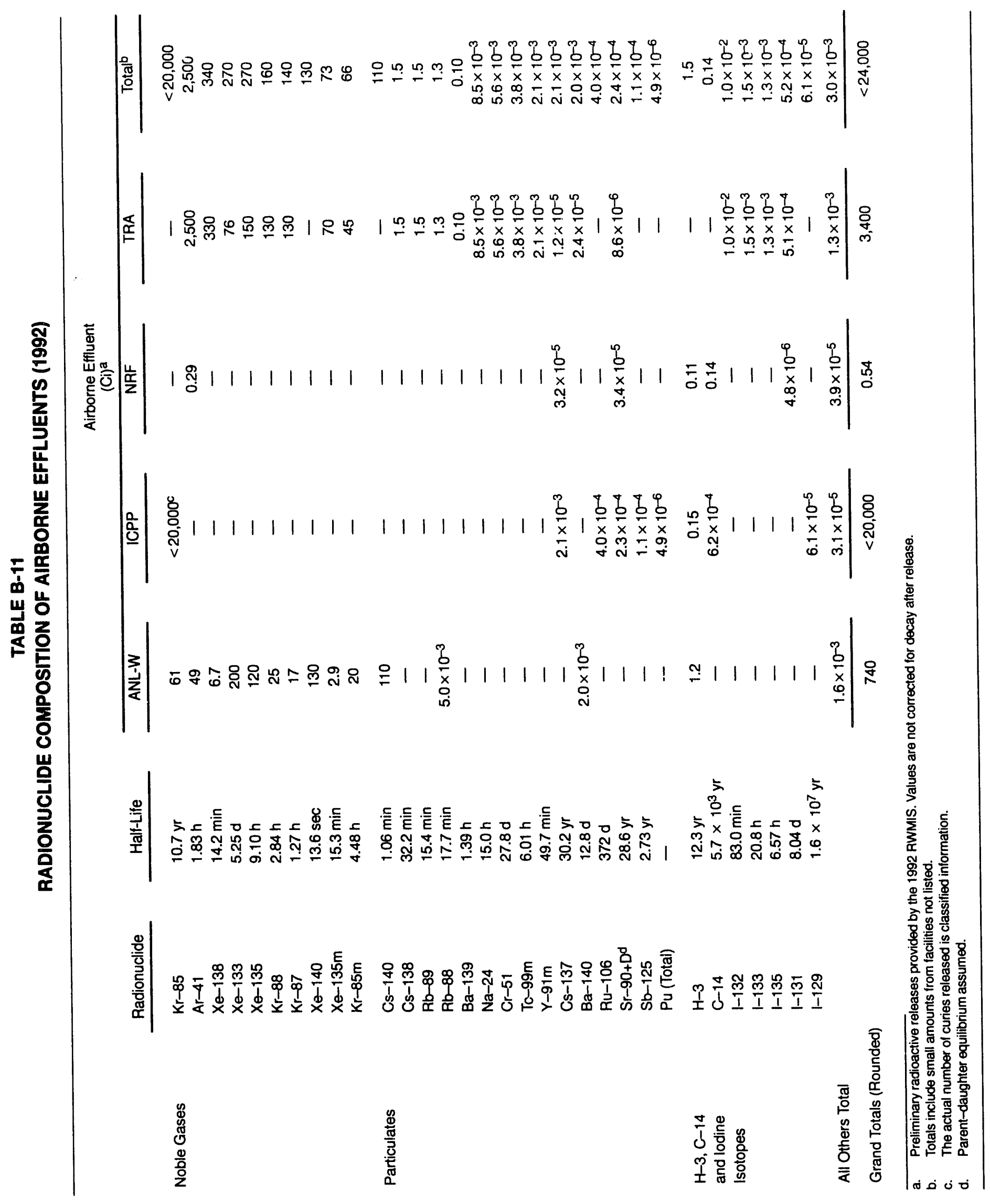




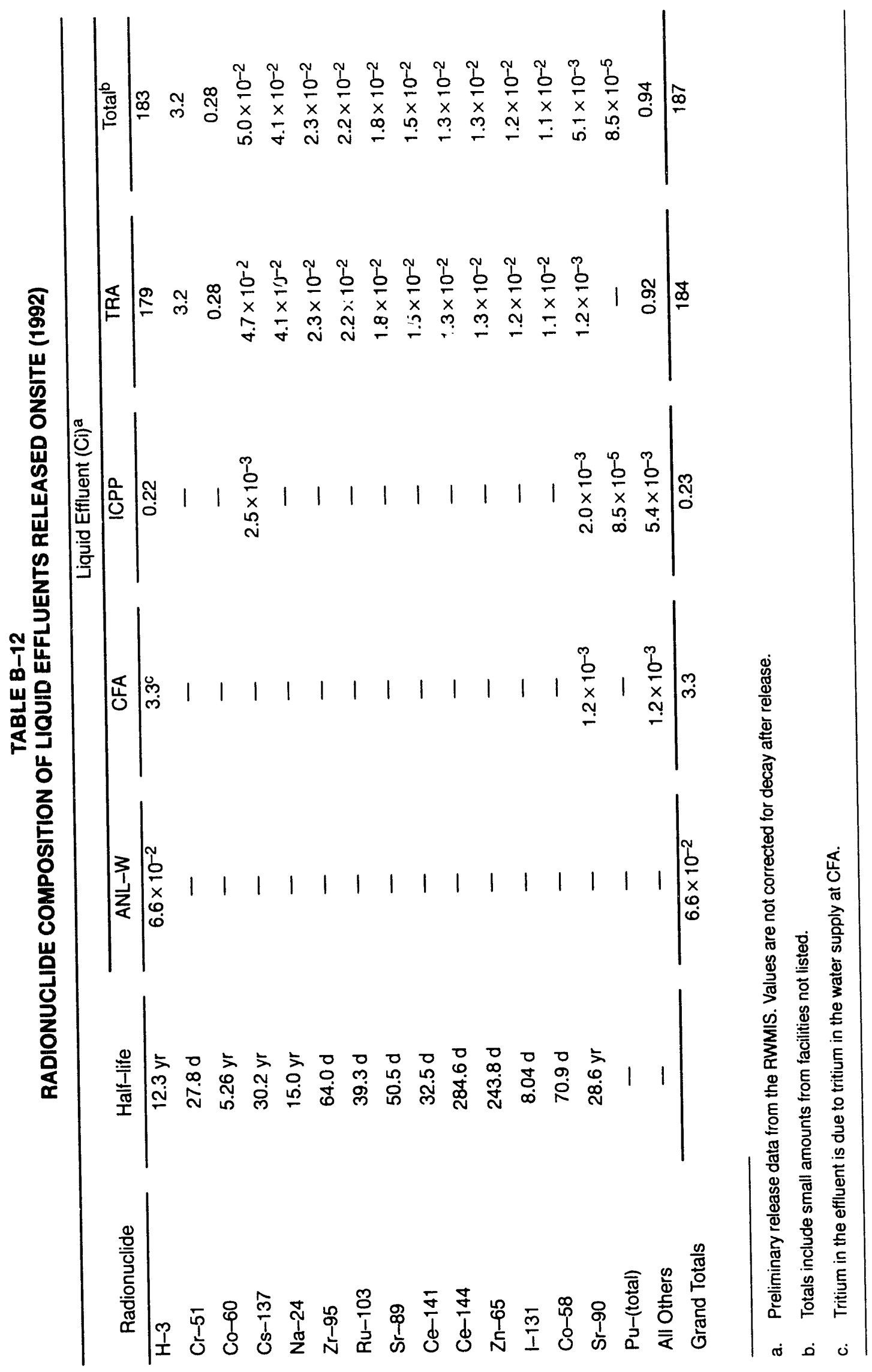

B-16 
TABLE B-13

EG\&G IDAHO RADIOLOGICAL DRINKING WATER DATA (1992)

(Analyses by Accu-Labs Research, Inc.)

\begin{tabular}{|c|c|c|c|c|}
\hline Location & Sample Date & $\begin{array}{l}\text { Gross Alpha } \\
\text { (pCi/L) }\end{array}$ & $\begin{array}{c}\text { Gross Beta } \\
(\mathrm{pCi} / \mathrm{L})\end{array}$ & $\begin{array}{c}\text { Tritium } \\
\left(10^{3} \mathrm{pCi} / \mathrm{L}\right) \\
\end{array}$ \\
\hline \multirow[t]{2}{*}{ CFA $641(D)^{b}$} & $05 / 07 / 92$ & $4 \pm 1$ & $3 \pm 2$ & $17 \pm 1$ \\
\hline & $07 / 09 / 92$ & - & 一 & $18 \pm 1$ \\
\hline \multirow[t]{2}{*}{ CFA 662 (D) } & 05/07/92 & - & - & $17 \pm 1$ \\
\hline & $07 / 09 / 92$ & - & - & $18 \pm 1$ \\
\hline \multirow[t]{2}{*}{ CFA \#1, 651} & $05 / 07 / 92$ & - & - & $19 \pm 1$ \\
\hline & U7/09/92 & - & - & $20 \pm 1$ \\
\hline CFA \#2, 642 & $05 / 07 / 92$ & - & - & $16 \pm 1$ \\
\hline Main Gate & 05/06/92 & $2 \pm 1$ & $3 \pm 2$ & - \\
\hline PBF 602 (D) & 05/06/92 & $2 \pm 2$ & $2 \pm 2$ & - \\
\hline RWMC 604 (D) & $05 / 04 / 92$ & $2 \pm 1$ & $4 \pm 2$ & - \\
\hline EBR-I & $05 / 07 / 92$ & $2 \pm 1$ & $2 \pm 2$ & - \\
\hline Fire Station \#2 & $05 / 06 / 92$ & $1 \pm 1$ & $1 \pm 2$ & - \\
\hline Weapons Range (D) & $05 / 06 / 92$ & $5 \pm 3$ & $3 \pm 2$ & - \\
\hline TRA 608 (D) & $05 / 04 / 92$ & $2 \pm 1$ & $2 \pm 2$ & - \\
\hline TAN/CTF 614 (D) & 05/05/92 & $3 \pm 2$ & $2 \pm 2$ & - \\
\hline TAN/TSF 610 (D) & $05 / 05 / 92$ & $4 \pm 3$ & $2 \pm 2$ & - \\
\hline TAN/WRRTF 644 & $05 / 05 / 92$ & $2 \pm 1$ & $5 \pm 2$ & - \\
\hline \multicolumn{5}{|c|}{ a. Data are presented as results $\pm 2 s$, where " $2 s^{n}$ represents the $95 \%$ confidence level. } \\
\hline
\end{tabular}




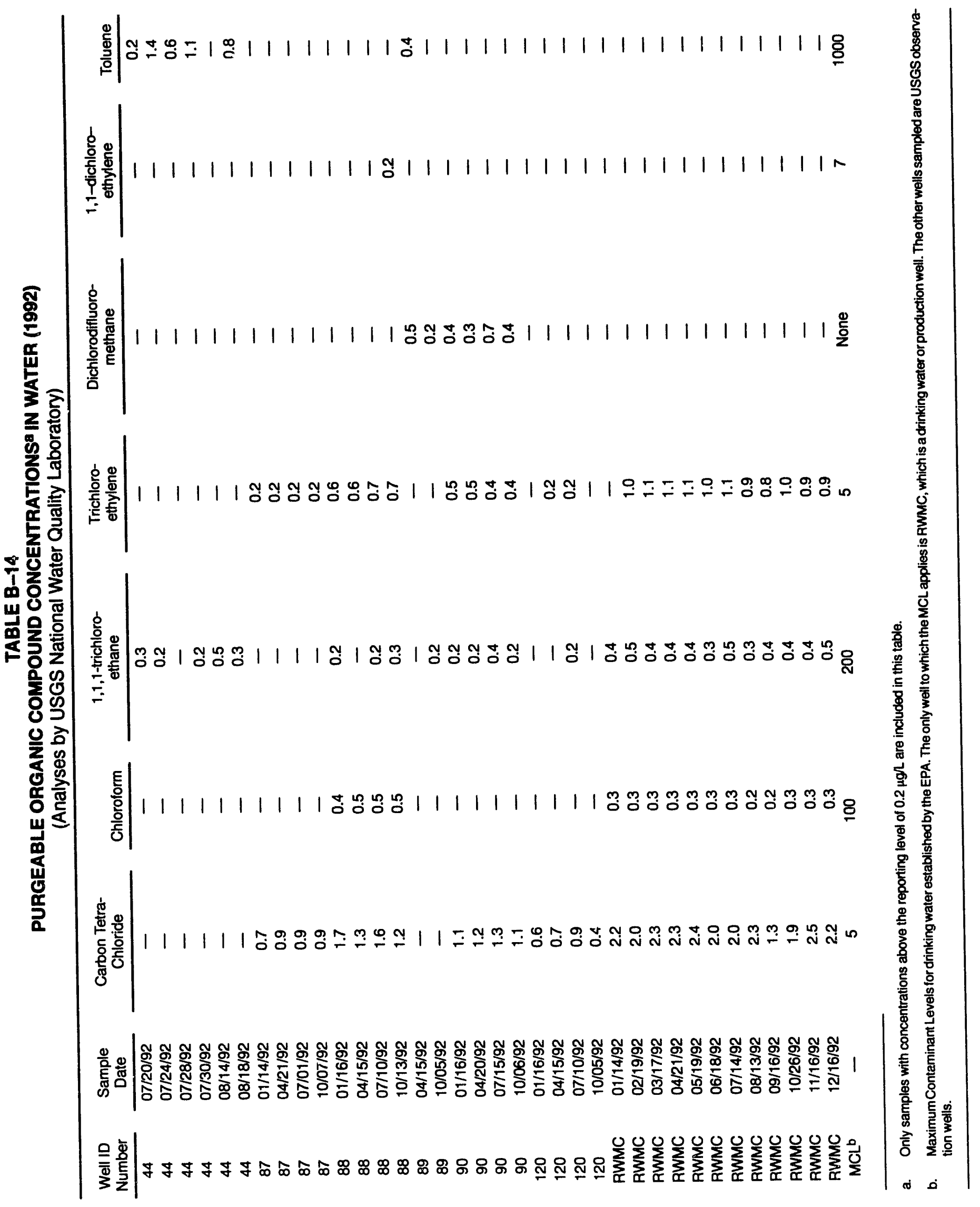

B-18 


\begin{tabular}{|c|c|c|c|c|c|}
\hline Location ID & $\begin{array}{l}\text { Month } \\
\text { Sampled }\end{array}$ & Trichloroethylene & Tetrachloroethylene & $\begin{array}{l}1,1,1- \\
\text { trichloroethane }\end{array}$ & $\begin{array}{c}\text { Carbon } \\
\text { Tetrachloride }\end{array}$ \\
\hline \multirow[t]{4}{*}{ CFA-641-D } & March & 0.7 & $-c$ & - & - \\
\hline & June & 0.7 & - & - & - \\
\hline & September & 0.6 & - & - & - \\
\hline & November & 0.6 & - & - & - \\
\hline CFA-651-Wd & March & 0.6 & - & - & - \\
\hline \multirow[t]{3}{*}{ (CFA \#1) } & June & - & - & - & - \\
\hline & September & 0.6 & - & - & - \\
\hline & November & 0.6 & - & - & - \\
\hline CFA-642-W & March & 0.9 & - & - & - \\
\hline \multirow[t]{3}{*}{ (CFÂ } & June & 0.9 & - & - & - \\
\hline & September & 0.7 & - & - & - \\
\hline & November & 0.8 & - & - & - \\
\hline Main Gate & March & - & - & 1.3 & - \\
\hline \multirow[t]{3}{*}{ (BADG) } & June & - & - & 1.1 & - \\
\hline & August & - & - & 0.9 & - \\
\hline & November & - & - & 1.1 & - \\
\hline \multirow{3}{*}{$\begin{array}{l}\text { Fire Station \#2-W } \\
\text { (FIRE) }\end{array}$} & June & - & - & 1.2 & - \\
\hline & August & - & - & 0.8 & - \\
\hline & November & - & - & - & - \\
\hline \multirow[t]{4}{*}{ RWMC-603-W } & March & - & - & - & - \\
\hline & June & 1.0 & - & - & 1.7 \\
\hline & September & 0.9 & - & - & 1.5 \\
\hline & November & 0.8 & - & - & 1.9 \\
\hline \multirow[t]{3}{*}{ RWMC-604-D } & June & 0.7 & - & 0.8 & - \\
\hline & September & 0.7 & - & 0.8 & - \\
\hline & November & 0.5 & - & 0.8 & - \\
\hline \multirow[t]{13}{*}{ TAN-612-W } & January & 6.6 & 1.9 & - & - \\
\hline & February & 6.5 & 1.9 & - & - \\
\hline & March & 5.7 & 1.5 & - & - \\
\hline & April & 5.0 & 1.8 & - & - \\
\hline & May & 4.8 & 1.4 & - & - \\
\hline & June & 4.3 & 1.2 & - & - \\
\hline & July & 9.2 & 2.6 & - & - \\
\hline & August & 14.0 & 3.6 & - & - \\
\hline & September & 14.1 & 3.5 & - & - \\
\hline & October & 13.4 & 3.5 & - & - \\
\hline & November & 14.2 & 4.1 & - & - \\
\hline & December & 11.2 & 2.9 & - & - \\
\hline & & B-19 & & & \\
\hline
\end{tabular}


TABLE B-15. (continued).

\begin{tabular}{|c|c|c|c|c|c|}
\hline Location ID & $\begin{array}{c}\text { Month } \\
\text { Sampled }\end{array}$ & Trichloroethylene & Tetrachloroethylene & $\begin{array}{c}1,1,1- \\
\text { trichloroethane }\end{array}$ & $\begin{array}{c}\text { Carbon } \\
\text { Tetrachloride } \\
\end{array}$ \\
\hline \multirow[t]{11}{*}{ TAN-613-W } & January & 5.3 & 1.3 & - & - \\
\hline & February & 4.9 & 1.2 & - & - \\
\hline & March & 3.9 & 1.0 & - & 一 \\
\hline & April & 3.2 & 0.9 & - & - \\
\hline & May & 3.9 & 1.0 & - & - \\
\hline & June & 6.4 & 1.5 & - & - \\
\hline & July & 5.1 & 1.3 & - & - \\
\hline & August & 4.9 & 1.3 & - & - \\
\hline & September & 3.2 & 0.9 & - & - \\
\hline & November & 2.2 & 0.8 & - & - \\
\hline & December & 2.3 & 0.7 & - & - \\
\hline \multirow[t]{12}{*}{ TAN-610-D } & January & 1.2 & - & - & - \\
\hline & February & 1.0 & - & - & - \\
\hline & March & 1.3 & - & - & - \\
\hline & April & 0.9 & - & - & - \\
\hline & May & 1.1 & - & - & - \\
\hline & June & 1.9 & - & - & - \\
\hline & July & 1.4 & - & - & - \\
\hline & August & 2.2 & - & - & - \\
\hline & Septembere & 7.7 & - & - & - \\
\hline & October & 11.7 & - & - & - \\
\hline & November & 2.6 & - & - & - \\
\hline & December & 2.4 & - & - & - \\
\hline \multirow[t]{3}{*}{ TAN-602-D } & January & 1.1 & - & - & - \\
\hline & March & 1.3 & - & - & - \\
\hline & June & 1.9 & - & - & - \\
\hline \multirow[t]{4}{*}{ TAN-WRRTF-D } & March & 3.1 & 1.0 & - & - \\
\hline & June & 8.3 & 3.1 & - & - \\
\hline & August & 7.3 & 2.6 & - & - \\
\hline & November & 7.6 & 3.1 & - & - \\
\hline$M^{\prime}$ & - & 5.0 & none & 200.0 & 5.0 \\
\hline \multicolumn{6}{|c|}{ a. Concentrations are reported in $\mu g / L$. } \\
\hline \multicolumn{6}{|c|}{ b. "D" refers to distribution system sample. } \\
\hline \multicolumn{6}{|c|}{ c. Concentrations were below detection limits. This is also true of samples from facilities not listed in this table. } \\
\hline \multicolumn{6}{|c|}{$\begin{array}{l}\text { d. "W" refers to a sample collected at the wellhead. (RESLUSGS location code names of selected wells are given in parentheses } \\
\text { for comparison purposes). }\end{array}$} \\
\hline \multicolumn{6}{|c|}{$\begin{array}{l}\text { e. The sparger unit at TSF (TAN) was out of service during September and October. Personnel were drinking bottled water, samples } \\
\text { were collected for information, not compliance purposes. }\end{array}$} \\
\hline f. Maximum Cont & Levels set by EPA & & & & \\
\hline
\end{tabular}




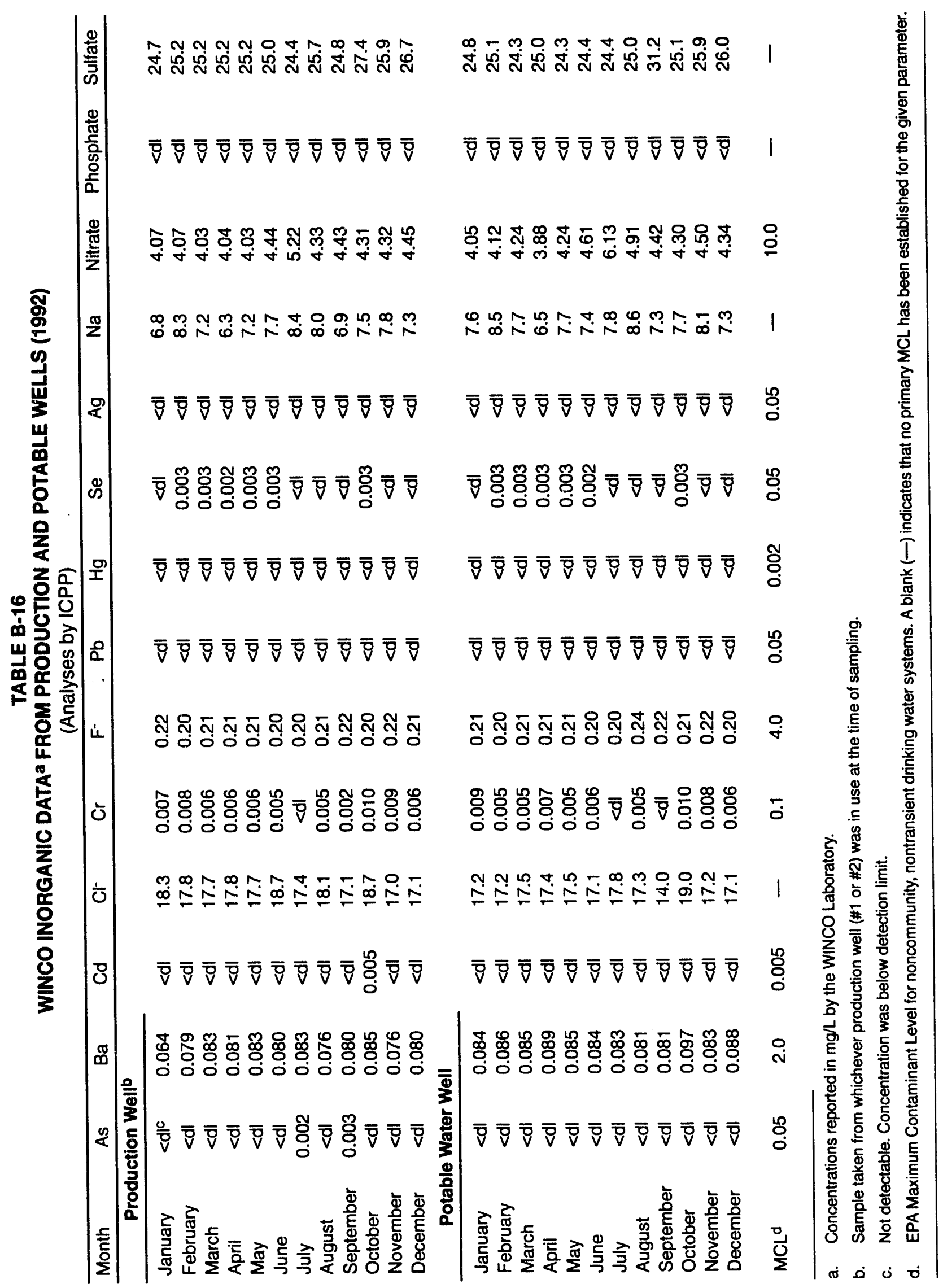


TABLE B-17

TOTAL SUSPENDED PARTICULATE MATTER CONCENTRATIONS IN AIR (1992)

\begin{tabular}{|c|c|c|c|}
\hline \multirow[b]{2}{*}{ Group } & \multirow[b]{2}{*}{ Location } & \multicolumn{2}{|c|}{$\begin{array}{l}\text { Concentrationa } \\
\left(\mu \mathrm{g} / \mathrm{m}^{3}\right)\end{array}$} \\
\hline & & Range & Mean ${ }^{b}$ \\
\hline \multirow[t]{5}{*}{ Distant } & Blackfoot & $14-40$ & $23 \pm 17$ \\
\hline & Craters of the Moon & 4-15 & $10 \pm 7$ \\
\hline & Idaho Falls & $30-50$ & $38 \pm 15$ \\
\hline & Rexburg & $20-40$ & $32 \pm 13$ \\
\hline & Grand Mean ${ }^{b}$ & & $26 \pm 19$ \\
\hline \multirow[t]{8}{*}{ Boundary } & Arco & $20-40$ & $33 \pm 12$ \\
\hline & Atomic City & $7-30$ & $17 \pm 15$ \\
\hline & FAA Tower & $5-14$ & $10 \pm 7$ \\
\hline & Howe & $13-40$ & $26 \pm 20$ \\
\hline & Monteview & $20-50$ & $37 \pm 19$ \\
\hline & Mud Lake & $10-20$ & $18 \pm 9$ \\
\hline & Reno Ranch & $9-30$ & $17 \pm 16$ \\
\hline & Grand Mean & & $23 \pm 10$ \\
\hline \multirow[t]{13}{*}{ Site } & ANL-W & $13-20$ & $17 \pm 5$ \\
\hline & ARA & $8-14$ & $12 \pm 5$ \\
\hline & CFA & $5-15$ & $11 \pm 7$ \\
\hline & EBR-I & $5-14$ & $10 \pm 7$ \\
\hline & EFS & $8-16$ & $12 \pm 6$ \\
\hline & ICPP & $5-20$ & $14 \pm 11$ \\
\hline & NRF & $7-13$ & $10 \pm 4$ \\
\hline & PBF & $7-14$ & $10 \pm 6$ \\
\hline & RWMC & $9-30$ & $19 \pm 17$ \\
\hline & TAN & $15-20$ & $18 \pm 4$ \\
\hline & TRA & $6-14$ & $11 \pm 7$ \\
\hline & VAINB & $8-18$ & $14 \pm 11$ \\
\hline & Grand Mean ${ }^{b}$ & & $13 \pm 2$ \\
\hline \multicolumn{4}{|c|}{$\begin{array}{l}\text { The approximate minimum detectable concentration is } 10 \mu \mathrm{g} / \mathrm{m}^{3} \text {. The EPA's national primary and secondary ambient air quality } \\
\text { standard is } 50 \mu \mathrm{g} / \mathrm{m}^{3} \text {, annual average, for particulates with diameter less than or equal to } 10 \mu \mathrm{m} \text {. }\end{array}$} \\
\hline \multicolumn{4}{|c|}{ Arithmetic mean with the $95 \%$ confidence interval for the mean (see Appendix C). } \\
\hline
\end{tabular}


TABLE B-18

NINE-YEAR SUMMARY OF PARTICULATE MATTER CONCENTRATIONS (1984-1992)

\begin{tabular}{|c|c|c|c|c|}
\hline & \multirow[b]{2}{*}{ Year } & \multicolumn{3}{|c|}{$\begin{array}{l}\text { Group Mean Concentration } \\
\left(\mu \mathrm{g} / \mathrm{m}^{3}\right)\end{array}$} \\
\hline & & Distant Group & Boundary Group & Onsite Group \\
\hline & $1984^{b}$ & $41 \pm 31$ & $20 \pm 2$ & $23 \pm 9$ \\
\hline & 1985 & $55 \pm 29$ & $33 \pm 12$ & $32 \pm 9$ \\
\hline & 1986 & $39 \pm 17$ & $31 \pm 9$ & $23 \pm 6$ \\
\hline & 1987 & $45 \pm 16$ & $34 \pm 8$ & $28 \pm 8$ \\
\hline & 1988 & $50 \pm 20$ & $35 \pm 9$ & $32 \pm 13$ \\
\hline & 1989 & $40 \pm 14$ & $30 \pm 7$ & $17 \pm 2$ \\
\hline & 1990 & $36 \pm 12$ & $32 \pm 8$ & $20 \pm 9$ \\
\hline & 1991 & $30 \pm 20$ & $28 \pm 12$ & $18 \pm 3$ \\
\hline & 1992 & $26 \pm 19$ & $23 \pm 10$ & $13 \pm 2$ \\
\hline & \multicolumn{4}{|c|}{ Arithmetic mean with the $95 \%$ confidence interval for the mean (see Appendix C). } \\
\hline J. & \multicolumn{4}{|c|}{$\begin{array}{l}\text { A major change in method using a more sensitive balance to measure pre-and post-collection masses of low-volume } \\
\text { air sampler filter composites was implemented in } 1984 \text {. }\end{array}$} \\
\hline
\end{tabular}




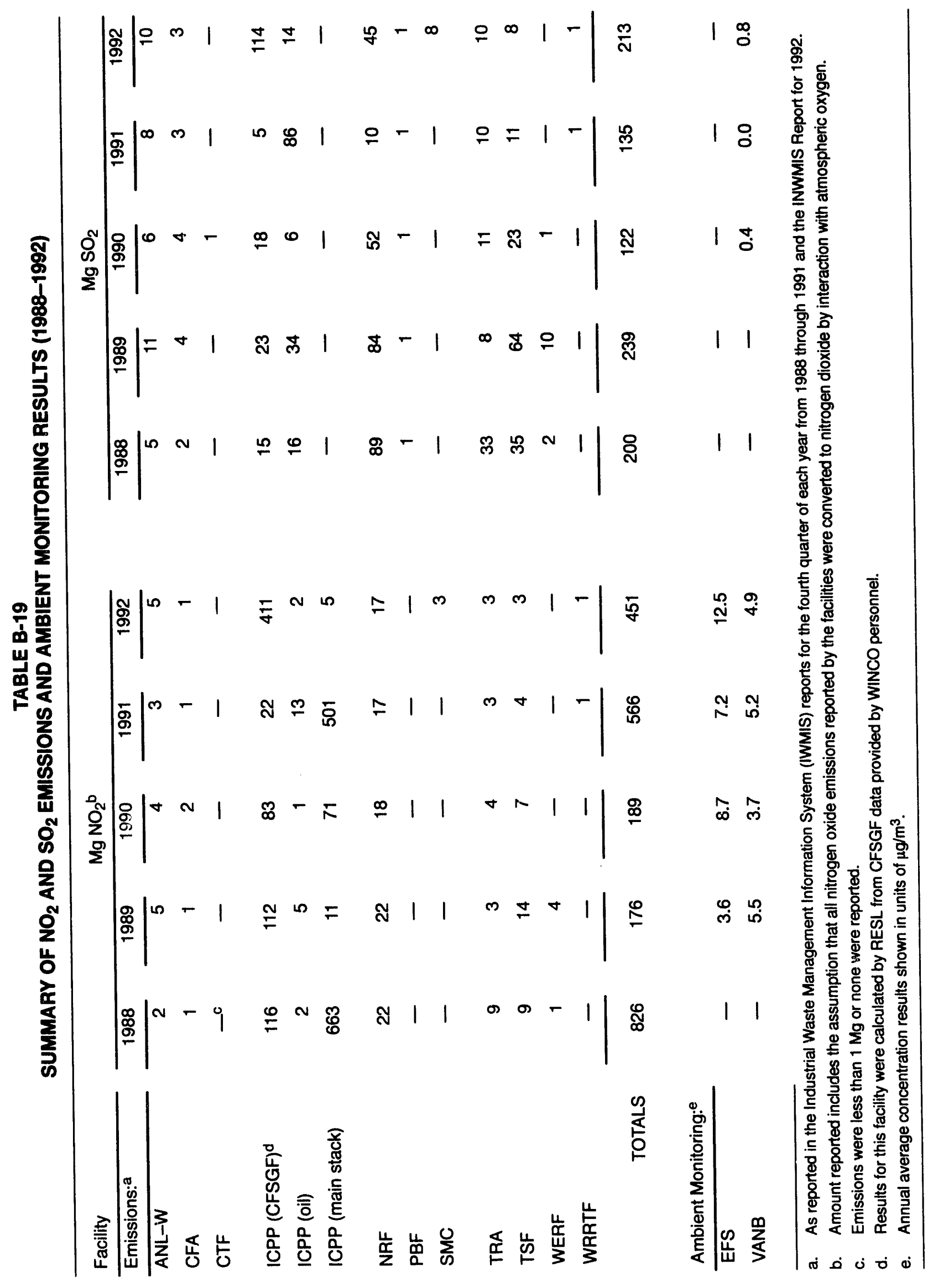




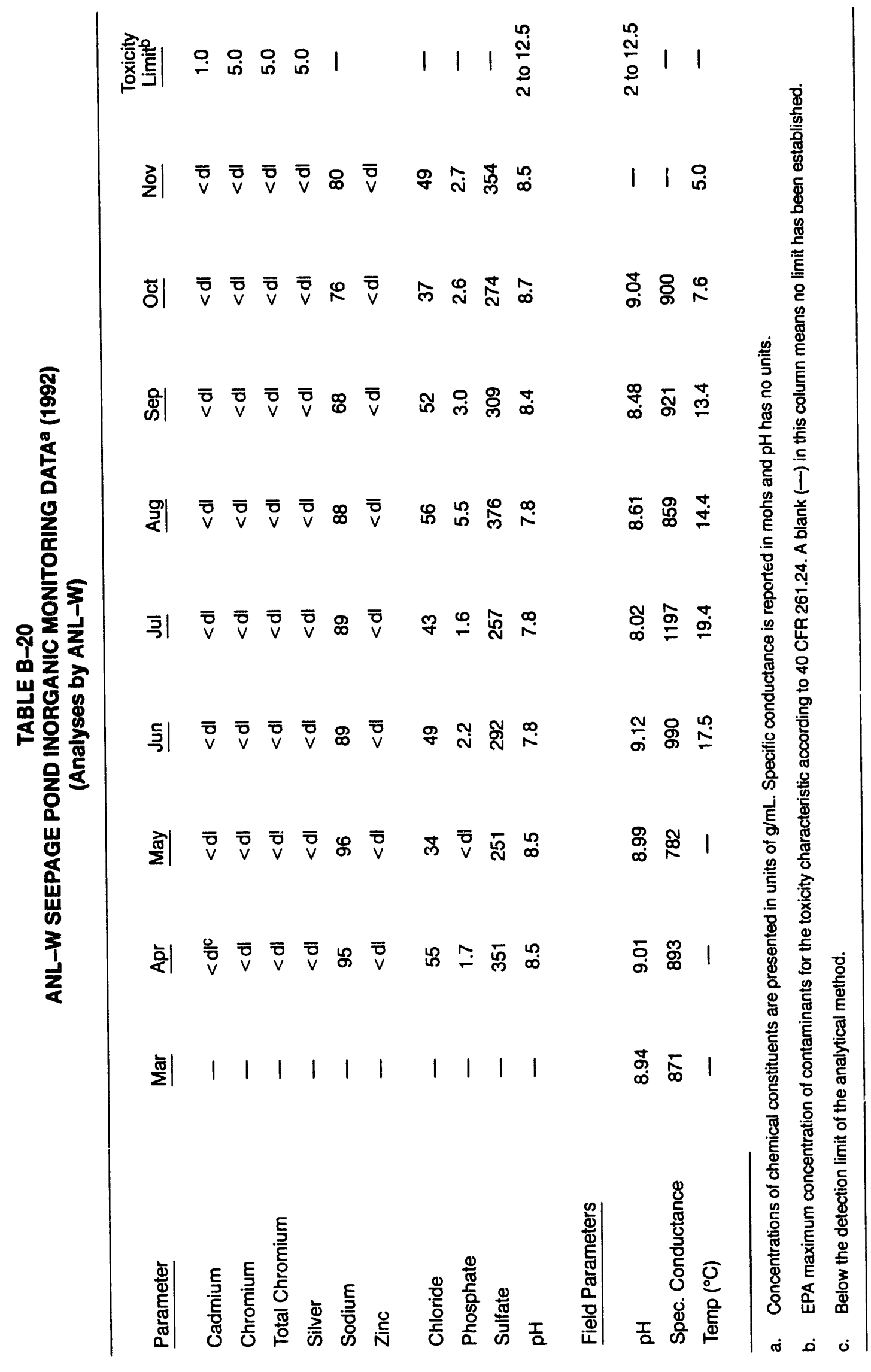


TABLE B-21

B\&W IDAHO BOILER EFFLUENT/SANITARY WASTE DATA SUMMARYa

(First Quarter 1992-Analyses by B\&W Idaho)

\begin{tabular}{|c|c|c|c|c|}
\hline Parameter & Boiler & $\begin{array}{c}\text { SMC } \\
\text { Sanitary }\end{array}$ & $\begin{array}{c}\text { Trailer } \\
\text { Sanitary } \\
\end{array}$ & $\begin{array}{l}\text { Regulatory } \\
\text { Limit }^{\text {b }}\end{array}$ \\
\hline Barium & 1.3 & 3.3 & 1.9 & 100 \\
\hline Cadmium & $<1.0$ & $<1.0$ & $<1.0$ & 1 \\
\hline Chromium & 2.9 & 1.2 & 0.6 & 5 \\
\hline Lead & 0.17 & 0.13 & 0.06 & 5 \\
\hline Selenium & 0.011 & 0.01 & 0.007 & 1 \\
\hline Silver & 0.037 & 0.02 & $<0.5$ & 5 \\
\hline Total Uranium & $<0.1$ & $<0.1$ & $<0.1$ & $N / A^{C}$ \\
\hline $\mathrm{pH}$ & 9.8 & 7.1 & 7.3 & 2 to 12.5 \\
\hline Tital Organic & $N D^{d}$ & ND & ND & N/A \\
\hline $\begin{array}{l}\text { a. Parameters are } \\
\text { b. EPA maximum } \\
\text { c. Not applicable. } \\
\text { d. None detected. }\end{array}$ & $\begin{array}{l}g / \mathrm{mL} \text { except } \\
\text { of contamin }\end{array}$ & $\begin{array}{l}\text { has no units } \\
\text { xicity charac }\end{array}$ & CFR 261.24 & \\
\hline
\end{tabular}


TABLE B-22

TRA LIQUID EFFLUENT TO COLD WASTE POND INORGANIC MONITORING DATAa (1992)

\begin{tabular}{|c|c|c|c|c|c|c|c|c|c|}
\hline \multirow[b]{2}{*}{ Parameter } & \multicolumn{2}{|c|}{ January } & \multicolumn{2}{|c|}{ February } & \multicolumn{2}{|c|}{ March } & \multicolumn{2}{|c|}{ July } & \multirow{2}{*}{$\begin{array}{l}\text { Toxicity } \\
\text { Limitb }\end{array}$} \\
\hline & 1 & 2 & 1 & 2 & 1 & 2 & 1 & 2 & \\
\hline Conductivity & 30.4 & 25.0 & 34.1 & 27.1 & $-^{c}$ & - & 399 & 375 & - \\
\hline & 8.52 & 8.58 & 7.90 & 7.99 & - & - & 7.70 & 8.20 & 2 to 12.5 \\
\hline TOCd & 0.56 & 1.55 & - & - & - & - & - & - & - \\
\hline $\mathrm{COD}^{\mathrm{e}}$ & - & - & - & - & $<d f^{\prime}$ & $<\mathrm{dl}$ & $<\mathrm{dl}$ & 6.30 & 一 \\
\hline MBASg & - & - & - & - & $<\mathrm{dl}$ & $<\mathrm{dl}$ & $<d l$ & $<\mathrm{dl}$ & - \\
\hline Chloride ion & 11.3 & 10.6 & - & - & - & - & - & - & - \\
\hline Fluoride ion & 0.16 & 0.17 & - & - & 0.16 & 0.16 & 0.14 & 0.15 & - \\
\hline Nitrate ion & 2.05 & 2.21 & - & - & 2.17 & 2.24 & 2.07 & 2.07 & - \\
\hline Phosphate ion & 0.17 & 0.25 & 一 & - & - & - & - & - & - \\
\hline Sulfate ion & 25.1 & 22.5 & - & - & - & - & - & - & - \\
\hline Antimony & $<d l$ & $<d l$ & $<d l$ & 0.024 & $<d l$ & $<d l$ & $<\mathrm{dl}$ & $<\mathrm{dl}$ & - \\
\hline Arsenic & $<d l$ & $<\mathrm{dl}$ & 0.002 & 0.002 & $<d l$ & $<\mathrm{dl}$ & $<\mathrm{dl}$ & 0.002 & 5.0 \\
\hline Barium & 0.038 & 0.036 & 0.045 & 0.045 & 0.045 & 0.043 & 0.052 & 0.058 & 100.0 \\
\hline Beryllium & $<\mathrm{dl}$ & $<d l$ & $<\mathrm{dl}$ & $<$ dl & $<\mathrm{dl}$ & $<\mathrm{dl}$ & 0.002 & $<\mathrm{dl}$ & - \\
\hline Cadmium & $<d l$ & $<d l$ & $<d l$ & $<d l$ & $<\mathrm{dl}$ & $<d l$ & $<\mathrm{dl}$ & $<d l$ & 1.0 \\
\hline Calcium & 44.2 & 44.9 & 44.0 & 44.2 & 43.6 & 42.5 & 44.9 & 45.0 & - \\
\hline Chromium & $<\mathrm{dl}$ & $<\mathrm{dl}$ & $<\mathrm{dl}$ & $<d l$ & 0.059 & $<d l$ & $<\mathrm{dl}$ & $<\mathrm{dl}$ & 5.0 \\
\hline Copper & 0.012 & 0.011 & $<d l$ & $<\mathrm{dl}$ & $<\mathrm{dl}$ & $<\mathrm{dl}$ & 0.018 & 0.017 & - \\
\hline Lead & $<\mathrm{dl}$ & $<d l$ & 0.001 & 0.002 & $<\mathrm{dl}$ & $<d l$ & 0.004 & 0.003 & 5.0 \\
\hline Magnesium & 16.3 & 16.6 & 16.6 & 16.8 & 16.4 & 16.0 & 16.2 & 16.2 & - \\
\hline Manganese & $<d l$ & $<$ dl & $<d l$ & $<d l$ & 0.004 & $<d l$ & 0.004 & $0.097^{h}$ & - \\
\hline Mercury & $<d l$ & $<d l$ & $<\mathrm{dl}$ & $<d l$ & $<\mathrm{dl}$ & $<d l$ & $<\mathrm{dl}$ & $<\mathrm{dl}$ & 0.2 \\
\hline Nickel & $<d l$ & $<\mathrm{dl}$ & $<d l$ & $<d l$ & $<\mathrm{dl}$ & $<\mathrm{dl}$ & $<\mathrm{dl}$ & $<\mathrm{dl}$ & - \\
\hline Selenium & 0.001 & 0.002 & 0.001 & 0.001 & $<\mathrm{dl}$ & $<d l$ & $<\mathrm{dl}$ & $<d l$ & 1.0 \\
\hline Silver & $<\mathrm{dl}$ & $<d l$ & $<d l$ & $<\mathrm{dl}$ & $<\mathrm{dl}$ & $<\mathrm{dl}$ & $<\mathrm{dl}$ & $<\mathrm{dl}$ & 5.0 \\
\hline Sodium & 7.97 & 8.13 & 7.37 & 7.46 & 7.52 & 7.24 & 88.5 & 85.7 & - \\
\hline Thallium & $<\mathrm{dl}$ & $<\mathrm{dl}$ & $<\mathrm{dl}$ & $<d l$ & $<\mathrm{dl}$ & $<\mathrm{dl}$ & 0.005 & $<\mathrm{dl}$ & - \\
\hline Zinc & 0.024 & 0.021 & 0.062 & 0.062 & 0.045 & 0.043 & 0.048 & 0.042 & - \\
\hline
\end{tabular}

a. Concentrations are reported in $\mathrm{mg} / \mathrm{L}$ except for Conductivity $(\mu \mathrm{S})$ and $\mathrm{pH}$, which has no units.

b. EPA maximum concentration of contaminants for the toxicity characteristic from 40 CFR261.24. A blank ( - ) in this column means no limit has been established.

c. No sample analysis was done for this parameter.

d. TOC represents concentration of total organic carbon in the sample.

e. COD represents chemical oxygen demand.

f. Concentrations were below the detection limit of the analysis.

g. MBAS represents an analysis for surfactants.

h. No explanation was found for the large difference between replicate samples. 


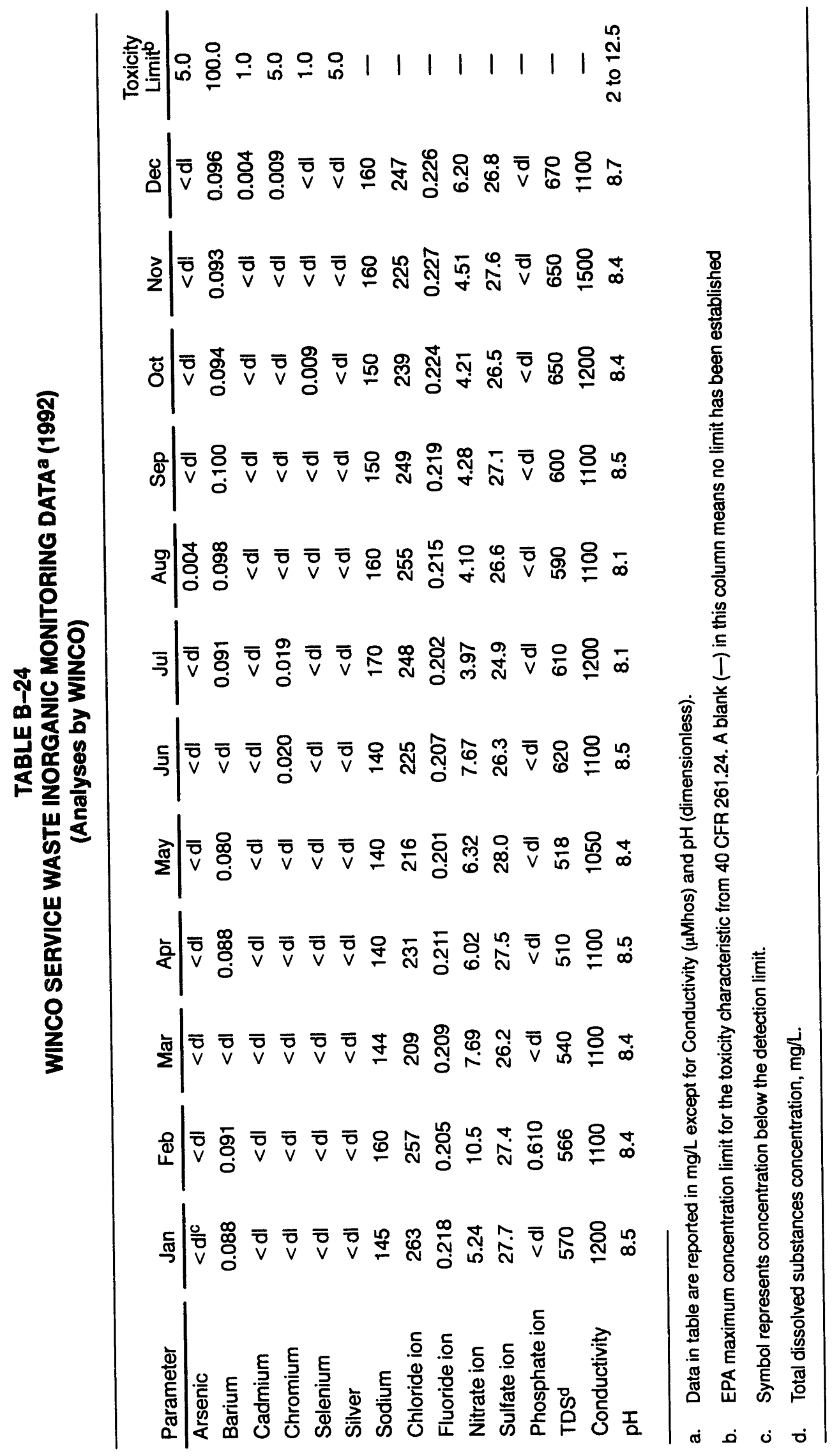




\section{APPENDIX C \\ STATISTICAL METHODS USED BY RESL FOR THE ENVIRONMENTAL SURVEILLANCE PROGRAM}




$$
\text { C-2 }
$$




\section{APPENDIX C}

\section{STATISTICAL METHODS USED BY RESL FOR THE ENVIRONMENTAL SURVEILLANCE PROGRAM}

Relatively simple statistical procedures are used to analyze the data from the RESL environmental surveillance program. ESB personnel initially review field collection information and analytical results to determine whether there are identifiable errors that would invalidate or limit the use of the results. Examples of these might be power outages at air sampler locations, torn membrane filters, or evidence of laboratory cross-contamination. Data that pass this initial screening are then evaluated for statistical significance with respect to laboratory analytical uncertainties, sample locations, reported releases from INEL operations, meteorological data, and worldwide events that might conceivably have an effect on the INEL environment.

For radiological data, individual analytical results are presented in this report with plus or minus $( \pm)$ two analytical standard deviations (2s), where all analytical uncertainties have been estimated, and " $\mathrm{s}$ " is an estimate of the population standard deviation " $\sigma$." Many of the results were less than or equal to $2 s$ (and, in fact, some were negative), which means that they were below the minimum detectable concentration. For example, in gamma spectrometric analyses, a given radionuclide is not considered detected unless the net count in the peak is greater than three times its estimated analytical uncertainty $(3 \mathrm{~s})$. If the result lies in the range of two to three times its estimated analytical uncertainty ( $2 \mathrm{~s}$ to $3 \mathrm{~s}$ ), and assuming that the result belongs to a Gaussian distribution, detection of the material by the analysis may be questionable because of statistical variations within the group of samples. If the result exceeds $3 \mathrm{~s}$, there is confidence that the material was detected (that the radionuclide was present in the sample).

A. deliberate search for specific nuclides can be made and results reported, but such results might include negative values or small positive values where the result is less than or equal to $2 \mathrm{~s}$. Analyses with results in the questionable range ( $2 \mathrm{~s}$ to $3 \mathrm{~s}$ ) are published in this report with the understanding that there is some doubt as to whether the material was actually present.

There are many factors that can influence the result to some degree, and these factors are considered and included in the methods used to determine the estimated uncertainty of the measurement. Uncertainties in measurements near the minimum detectable concentration are primarily caused by counting statistics. For low concentrations near the minimum detectable concentration, the uncertainty in the measurement is nearly equal to the measurement itself, and the lower limit of the range of the measurement approaches "zero." Such a result might not be very reliable because the uncertainty is only an estimate and the actual probability distribution of the results is not usually known. In reality, the material being measured may not actually be present in the sample. Therefore, when analytical results show a measurement very near the minimum detectable concentration, statistical tools, meteorological data, and Site release information are all considered when interpreting and evaluating the results.

Arithmetic means were calculated using actual assay results, regardless of their being above or below the minimum detectable concentration. The uncertainty of the mean, or the $95 \%$ confidence interval, was determined by multiplying the standard deviation of the mean (also called the standard error of the mean) or $s /(n)^{1 / 2}$ by the $t_{(0.05)}$ statistic. Means for which the $95 \%$ confidence interval does not include zero were assumed to indicate detectable amounts of activity. In situations where the analytical results of a group of samples are near the minimum detectable concentration, the $95 \%$ confidence interval for the mean may not include zero and thus appears to be statistically significant even though, on the basis of the $2 \mathrm{~s}-$ to- $3 \mathrm{~s}$ criterion, it is doubtful that any individual sample contained detectable radioactivity.

Geometric means were calculated by summing the natural logarithms (ln) of the positive analytical results, dividing by the number of samples $(n)$, and then transforming the quotient. If the result was either a 
negative number or a zero, the ln of the smallest positive, nonzero measurement in the group was used. The 95\% confidence interval was determined by multiplying the standard deviation of the geometric mean by the $t_{(0.05)}$ statistic and then transforming the result. The actual interval is determined by dividing the transformed mean by the transformed $95 \%$ confidence interval term for the lower limit, then multiplying the mean by the confidence interval term for the upper limit.

Unpaired t-tests were used to determine whether the annual means for the Site or boundary stations were greater than the annual means for the distant stations. All statistical tests used a level of significance of $5 \%$ $(\alpha=0.05)$. $^{\mathrm{C}-1}$

\section{REFERENCE}

C-1 Lyman Ott, An Introduction to Statistical Methods and Data Analysis, Boston, Massachusetts: Duxbury Press, 1977. 


\section{DISTRIBUTION RECORD FOR DOE/ID-12082(92)}

Internal Distribution

\section{DOE-ID}

B. S. Anderson, A D/OSD (3)

G. C. Bowman, M/OES\&HO

T. F. Bums, Jr., M/ER\&WM

G. E. Dials, AM/S\&ES

P. J. Dirkmaat, D/RESL

J. R. Harper, AM/A

M. B. Hinman, D/ESD

D. S. Hurtt, D/OEA

C. Ljungberg, D/E\&QAD

C. R. Nichols, AM/EP

A. A. Pitrolo, Manager

I. Resendez, $\mathrm{CC} / \mathrm{OCC}$

R. M. Stallman, AM/NP

J. M. Wilcynski, DM/BM

E. L. Wilmot, DM/O

E. J. Ziemianski, D/TSD

EG\&G Idaho, Inc.

D. J. Claflin, TP (8)

P. N. Creighton, M/OMB

E. N. Fray, Manager

W. E. Harrison, M/EE\&LS

D. J. Harvego, M/CFA Facil.

R. D. Johnson, M/S\&E

K. Langley, M/PRP, RCO

J. L. McAnally, DM/ER/WM

P. North, M/ER\&A

J. C. Okeson, DM/PRP

B. D. Reyes, M/EP

L. V. Street, M/EMU

R. S. Watkins, AM/ES\&Q

\section{Babcock \& Wilcox}

G. H. Baker, Gen. Mgr

A. M. Jensen, Dir., HS\&E

\section{Argonne-West}

J. I. Sackett, Manager

G. C. Marshall, M/ESWM

L. C. Witbeck, AM/SS\&S

Westinghouse Electric Corp.

J. G. Podgursky, M/EC (2)

J. L. Lucas, NRF Manager

\section{WINCO}

H. D. Christiansen, M/RS

L. F. Ermold, VP, Prod.

W. C. Moffitt, President

A. M. Umek, M/EC\&SIS

B. R. Wheeler, M/TD

\section{DOE-IBO}

T. M. Bradley, Manager

R. D. E. Newbry, Env. Proj. Off. (4)

\section{U.S. Geological Survey}

L. J. Mann, Project Chief

\section{NOAA ARLFRO}

C. R. Dickson, Director

RESL/ID (300)

Total Copies Printed-500 


\section{DISTRIBUTION LIST FOR DOE/ID-12082(92)}

\section{External Distribution}

Richard Aiken,

Environmental Audit,

DOE-HQ

Washington, DC

Jesse Aragon,

Health, Safety, and Environment,

LANL,

Los Alamos, NM

W. Bruce Arnell,

District Seven Health Department,

Idaho Falls, ID

Brian Balke,

Lawrence Livermore National Laboratory,

Livermore, CA

Robert W. Barber,

Compliance Programs,

DOE-HQ,

Washington, DC

Warren Barrash,

Division of Environmental Quality,

Idaho Department of Health and Welfare,

Boise, ID

Robert Bernero,

Nuclear Materials Safety and Safeguards, NRC,

Washington, DC

Carol M. Borgstrom,

NEPA Project Assistance,

DOE,

Washington, DC (2)

Dave Brekke,

Sandia National Laboratory,

Livermore, CA

Andrew Brunelle,

Office of the Governor of Idaho,

Boise, ID
Barry Burnell,

Southeastem District Health Department, Blackfoot, ID

Linford J. Campbell,

Idaho Department of Water Resources,

Boise, ID

William R. Carlton,

Health Protection Department,

Savannah River Site,

Aiken, SC

Bruce W. Church,

Environment, Safety, and Health,

DOE-LV,

Las Vegas, NV

Richard A. Claytor,

Defense Programs,

DOE-HQ,

Washington, DC

Audrey Cole,

Division of Environmental Quality,

Idaho Department of Health and Welfare,

Pocatello, ID

John C. Corey,

Environmental Sciences Section,

Savannah River Site,

Aiken, SC

J. Donald Cossairt,

Fermi Laboratory,

Batavia, IL

Charles Costa,

Environmental Monitoring \& Support

Laboratory, EPA,

Las Vegas, NV

Honorable Larry E. Craig,

U.S. Senate,

Washington, DC 
Honorable Michael Crapo,

U.S. House of Representatives,

Washington, DC

Jerry Daub,

Chem-Nuclear Geotech,

Grand Junction, CO

B. J. Davis,

Environmental Protection Division,

DOE Oak Ridge Operations Office,

Oak Ridge, TN

James T. Davis,

Environment, Safety \& Quality Assurance

Division,

DOE San Francisco Operations Office,

Oakland, CA

Linda England,

Westinghouse Materials Company of Ohio,

Cincinnati, $\mathrm{OH}$

Fred D. Ferate, II,

Environmental Science Department,

NTS,

Mercury, NV

Peter K. Fitzsimmons,

Health Physics and Environmental Division,

DOE-LV,

Las Vegas, NV

Michael Flannigan,

DOE,

Argonne Area Office-East,

Argonne, IL

Thomas F. Gesell,

Radiation Safety,

Idaho State University,

Pocatello, ID

Norbert Golchert,

Occupational Health \& Safety Department,

ANL,

Argonne, IL
Bernard Graham,

College of Pharmacy,

Idaho State University,

Pocatello, ID

Thomas P. Grumbly

Environmental Restoration and

Waste Management

DOE-HQ

Washington, DC

Thomas C. Gunderson,

Environmental Surveillance Group,

LANL,

Los Alamos, NM

William Gunter,

Criteria and Standards Division,

EPA,

Washington, DC (2)

James D. Heffner,

Savannah River Site,

Aiken, SC

R. Keith Higginson,

Idaho Department of Water Resources,

Boise, ID

Steve Hill,

Division of Environmental Quality,

Idaho Department of Health and Welfare,

Boise, ID

Ernest J. Hughes,

DOE,

Argonne Area Office-West,

Idaho Falls, ID

David Humphrey,

Division of Environmental Quality, Idaho Department of Health \& Welfare,

Boise, ID

Gerald V. Hurst,

Public Health District Five,

Twin Falls, ID

Hue-Su Hwang,

Sandia National Laboratory,

Albuquerque, NM 
Richard Jaquish,

Office of Hanford Environment,

PNL,

Richland, WA

Eric Jarvi,

College of Pharmacy,

Idaho State University,

Pocatello, ID

Jonathan Jarvis,

Craters of the Moon National Monumerit, Arco, ID

Paul Jehn,

Idaho Department of Health and Welfare,

Boise, ID

Randy L. Kaltreider,

Environmental Compliance Division,

DOE-HQ,

Washington, DC

Honorable Dirk Kempthorne,

U. S. Senate,

Washington, D.C.

Michael A. Kirkpatrick,

Environmental Audit,

DOE-HQ,

Washington, DC

Michael H. Kleinrock,

Environmental Compliance Division,

DOE-HQ,

Washington, DC

Phil Krey,

Environmental Measurements Laboratory, DOE,

New York, NY

Honorable Larry LaRocco,

U. S. House of Representatives,

Washington, D.C.

John Ledger,

Air Quality Bureau,

Idaho Department of Health and Welfare,

Boise, ID
Jerry Leitch,

Radiation Division,

EPA,

Seattle, WA

Larry J. Madl,

WIPP,

Carlsbad, NM

Helen McCammon,

Ecological Research,

OHER,

DOE-HQ,

Washington, DC

Daniel A. McGrath,

Pantex Plant,

Amarillo, TX

Robert P. Miltenberger,

Brookhaven National Laboratory,

Upton, NY

Leland Mink,

University of Idaho,

Moscow, ID

Henry Moran,

Division of Environmental Quality,

Idaho Department of Health and Welfare,

Pocatello, ID

John B. Murphy,

ORNL,

Oak Ridge, TN

Al Murray,

Division of Environmental Quality,

Idaho Department of Health and Welfare,

Boise, ID

Joe Nagel,

Division of Environmental Quality,

Idaho Department of Health and Welfare,

Boise, ID

Thomas Oakes,

Science Applications International Corporation,

Oak Ridge, TN 
William S. Osburn, Jr.,

Ecological Research Division,

OHER,

DOE-HQ,

Washington, DC

Jack Palmer,

Division of Environmental Quality,

Idaho Department of Health and Welfare,

Pocatello, ID

Raymond Pelletier,

Environmental Guidance,

DOE-HQ,

Washington, DC

Timothy D. Pflaum,

Environmental Safety and Health,

DOE-HQ,

Washington, DC

James A. Phoenix,

Technical Programs Branch,

DOE,

Los Alamos, NM

Esteban Picazo,

West Valley Nuclear Services,

West Valley, NY

Walter Poole,

Division of Environmental Quality,

Idaho Department of Health and Welfare,

Pocatello, ID

Allen Reed,

Reed's Dairy,

Idaho Falls, ID

Leslie L. Reed,

WIPP,

Carlsbad, NM

Lotwick Reese,

Idaho Department of Water Resources,

Boise, ID

Linda Rogers,

Westinghouse Materials Company of Ohio,

Cincinnati, $\mathrm{OH}$
Gene Runkle,

HPD,

DOE-AL,

Albuquerque, NM

Robie Russell,

Region-10,

EPA,

Seattle, WA

L. E. Scarburgh,

EPA Idaho Operations Office,

Boise, ID

Gary Schleimer,

Lawrence Berkeley Laboratory,

Berkeley, CA

Richard H. Schultz,

Idaho Department of Health and Welfare,

Boise, ID

Rajendra K. Sharma,

Fuel Cycle \& Test Programs,

DOE-HQ,

Washington, DC

George Setlock,

Health, Safety and Environment,

RFP,

Golden, CO

Michael Silverman,

EPA Idaho Operations Office,

Boise, ID

John M. Sims,

LLNL,

Livermore, CA

Constance L. Soden, Director,

Environmental Protection Division, DOE-AL,

Albuquerque, NM

Clive Strong,

Idaho Office of Attorney General,

Boise, ID

Leonard S. Sygitowicz,

REECO,

Las Vegas, NV 
A. L. Taboas,

DOE,

Chicago Area Office,

Argonne, IL

Kathleen I. Taimi, Director,

Environmental Compliance,

DOE-HQ,

Washington, DC

J. G. Themelis, Director,

Environment and Health Division,

DOE-AL,

Albuquerque, NM

Michael W. Tiernan,

Environmental Protection Branch,

DOE-RL,

Richland, WA
John Welhan,

Department of Geology,

ISU,

Pocatello, ID

Spence Wood,

Department of Geology and Geophysics,

BSU,

Boise, ID

Rodger Woodruff,

Surface Environmental and Surveillance Project, PNL,

Richland, WA

Norman Young,

Idaho Department of Water Resources,

Boise, ID

Paul Ziemer,

Environment, Safety and Health,

DOE-HQ,

Washington, DC
EG\&G INEL Technical Library,

Idaho Falls, ID (5)

Office of External Affairs and INEL Public Affairs (50)
Chicago Patent Group - DOE

Office of Scientific and Technical Information, TN (2) 

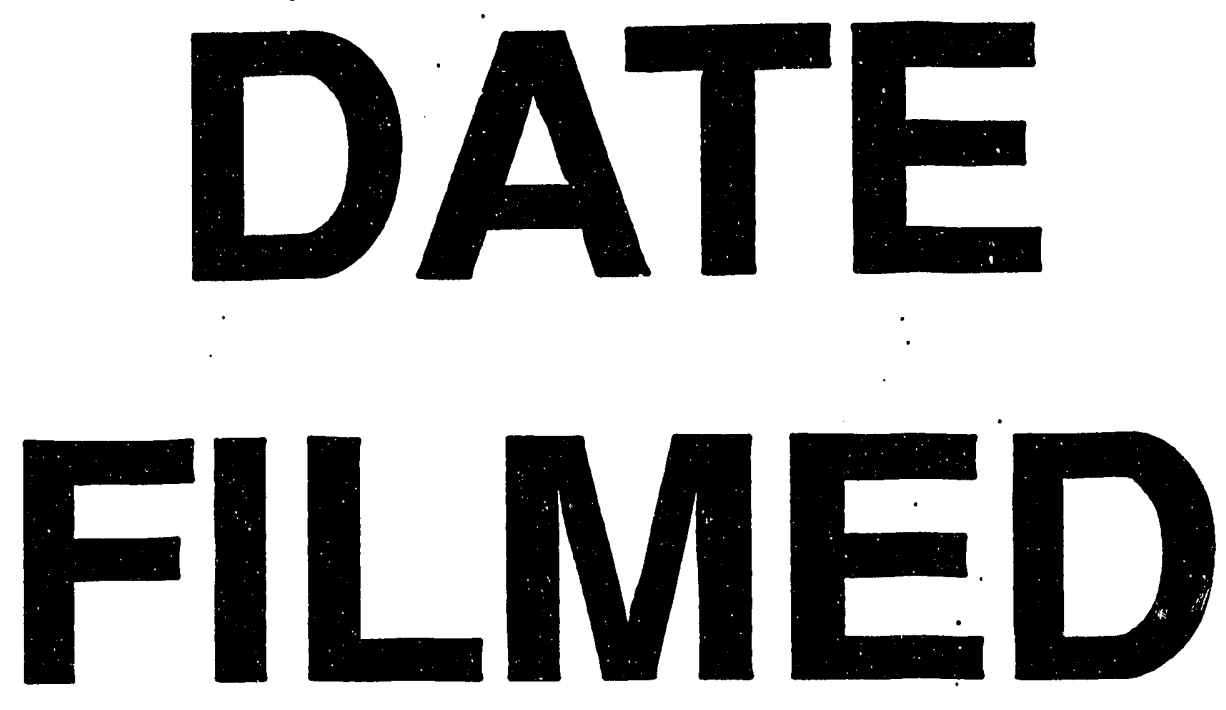

$10 / 12 / 93$
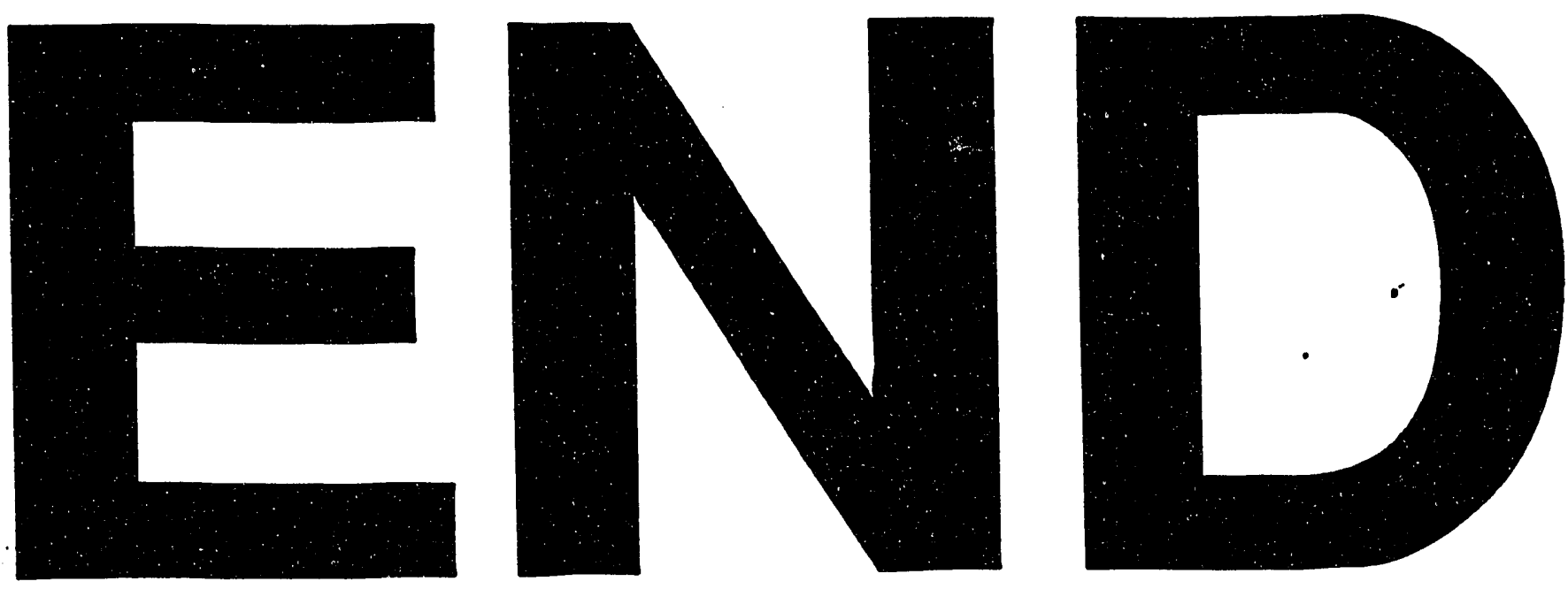
